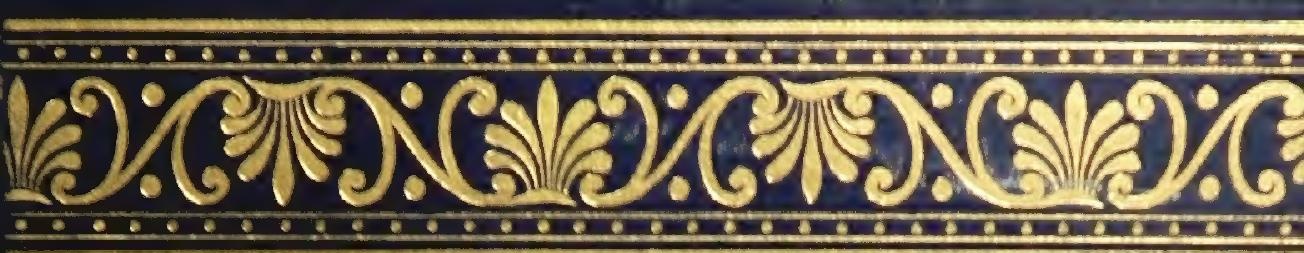

THE GREAT

\title{
WORLD'S FARM
}

SELINA GAYE

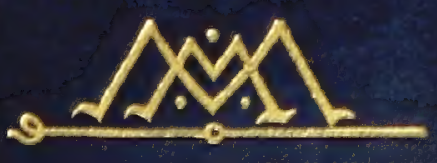




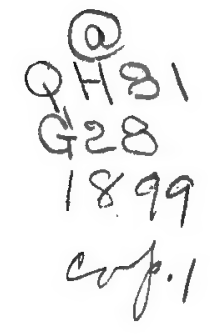

\title{
Cornell Unipersitq
}

\author{
Library \\ OF THE
}

Thew Dork state College of Agriculture

Aq.a15 $23|-10| 1$ 


\section{Cornell University Library}

\section{QH 81.G28}

some account of $n$

The great world's farm; some account of

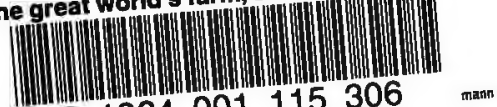

31924001115306 


\section{Cornell University Library}

The original of this book is in the Cornell University Library.

There are no known copyright restrictions in the United States on the use of the text.

http://www.archive.org/details/cu31924001115306 






\section{THE GREAT WORLD'S FARM}






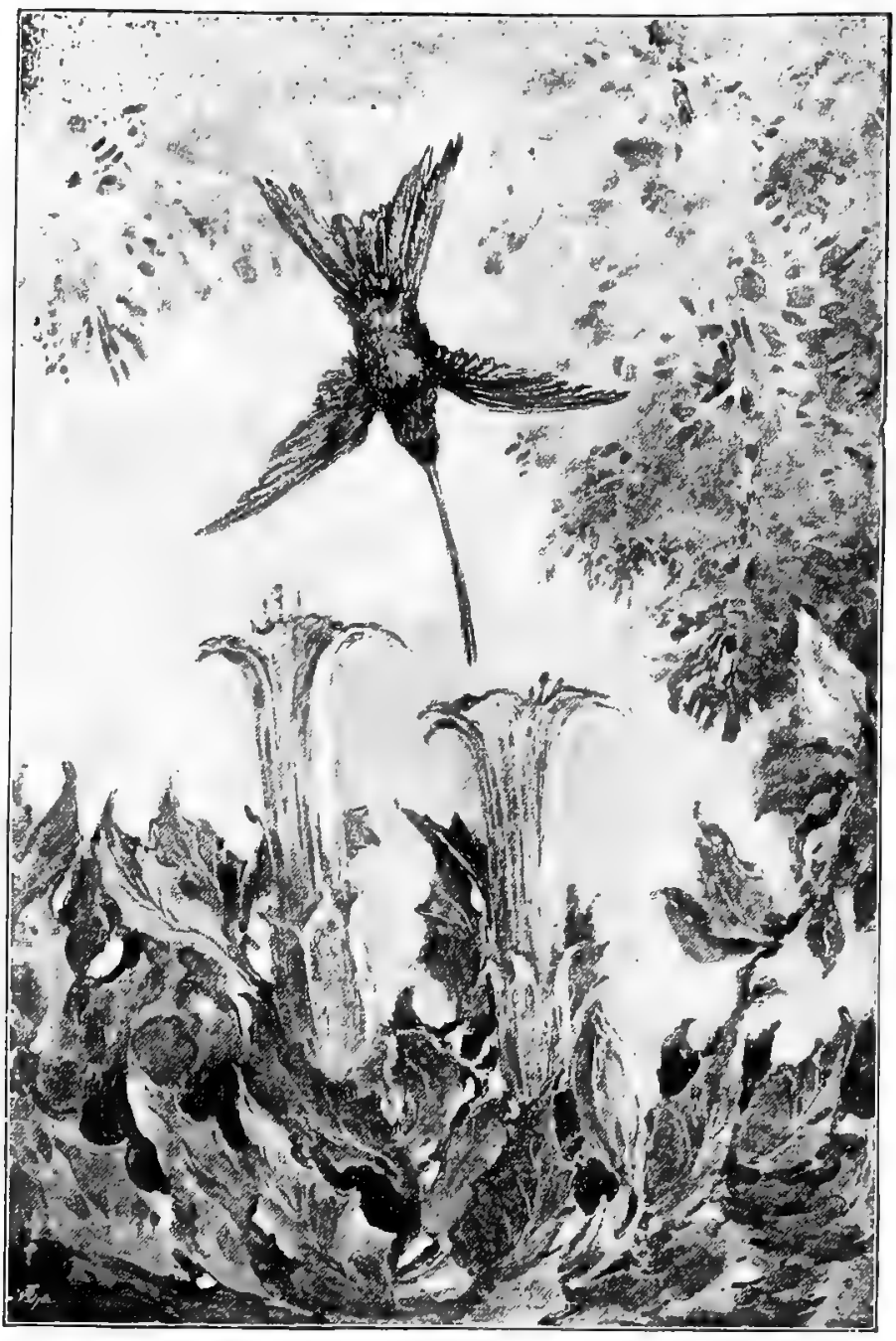






\title{
GREAT WORLD'S FARM
}

SOME ACCOUNT OF NATURE'S CROPS

AND HOW THEY ARE GROWN

\author{
BY \\ SELINA GAYE \\ Author of 'The World's Lumber-Room,' \\ 'Coming,' etc.
}

WITH A PREFACE BY

G. S. BOULGER, F.L.S., F.G.S.

Professor of Botany \& Geology in the City of London College

\begin{abstract}
The world is one vast garden, bringing forth crops of the most luxuriapt and varied kind, century after century, and millennium after millennium. Yet the face of Nature is nowhere furrowed by the plough, no harrow disintegrates the clods, no lime and phosphates are strewn upon its fields, no visible tillage of the soil improves the work on the great zvorld's farm."

H. Drummond, "Tropical Africa"
\end{abstract}

\section{New Work}

THE MACMILLAN COMPANY

LONDON: MACMILLAN \& CO., LTD.

1899

[ALL Rights RESERVID] 


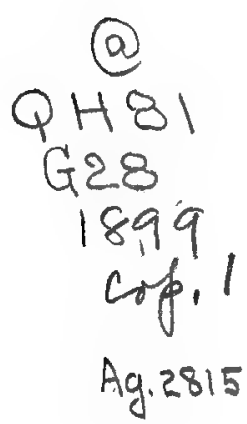




\section{P R E F A C E}

\section{BY G. S. Boulger, F.L.S., F.G.S.}

Prgessor of Botany and Geology in the City of London College.

IT cannot be too often insisted upon that knowledge, and not ignorance, is the true parent of reverential wonder. Our appreciation of the beauty of a flower is heightened, and not lessened, by the knowledge that each curve in its outline and each spot of colour on its petal has a definite utility in the plant-economy. Our admiration of a landscape is intensified, and not diminished by the thought that hill and dale owe their contour to the excavating power of rain and rivers operating through ages of time, and that the vegetation which clothes them has definite relations to the composition of the soil and to the character of the climate.

It has, therefore, been wisely recognised by all our modern authorities on the subject of education, that the study of some of the sciences should occupy an early and an important place in our school curriculum. It may be that those universal favourites, the flowers, which can anywhere be readily obtained, are to be the subject of study; or the innate love of experiment is to be fostered and directed in the chemical laboratory; or, perhaps better still, the physical features of the world around us, of sky and sea, of mountain and river, of crystal and pebble, are to be presented, not 
as isolated facts, but as the offspring of constant and universal law.

In the attempt, however, to employ the teaching of science as a means of education, to develop, that is, the innate mental faculties of a child, there are several dangers to which we are exposed: we may, for instance, make our subject so uninteresting that it becomes an irksome exercise of patience and memory, and so loses all its distinctive educational value; or, again, we may give much useful information, and even teach valuable lessons of observation, accuracy, and method, but fail to impart a sense of proportion, to show the interdependence of Nature as a whole, or the relation of our particular subject of study to others of equal importance.

Hence arises the great value of books, such as the present, which, while simple enough to be understood by unscientific readers, and so accurate as to teach nothing that will afterwards have to be unlearnt, are also extremely attractive in their selection and marshalling of facts.

A 'dry book' may do much mischief, for it may choke the promising but tender seedlings of curiosity ; and if, as the proverb says, "necessity is the mother of invention,' curiosity is certainly the mother of

- knowledge. Young people are generally provided by Nature with a plentiful supply of curiosity. They may yet, however, be very far from learning the fundamental methods of scientific inquiry. Scientific knowledge, it has often been explained, differs from other knowledge only in being accurate and in being systematic; and neither of these mental qualities seems to come altogether, like Dogberry's reading and writing, 'by nature.' The lesson of how to observe, and how to discriminate truth from falsehood, is one that we all 


\section{Preface}

have to learn. Scientific observations, too, demand sustained attention and very generally repetition and interpretation by such intellectual processes as comparison and classification. The reasoning faculties, by which such processes must be performed, require the guidance of more mature intelligence, not only to train them but even to bring them into operation at all. Nor does mental orderliness come more naturally than attention or discrimination.

We find, then, that we must interest, we must stimulate the power of observation, and we must elicit and guide the reasoning faculties. One never-failing method of effecting these three objects is to bring the young directly in contact with nature. To pick a bunch of flowers, to chip fossils from the quarry, to be shown some of the more conspicuous constellations on a starry night, or the moon's surface through a telescope, is sure to arouse intérest, and no competent teacher need then fail to find lessons that will not only instruct or impart information, but will also teach the art of reasoning. So, too, though most of the leading truths of physical geography can be illustrated anywhere, we might wish, in order to exhibit to the mind all the facts upon which those principles are based, to take the young student on extensive travels in many climes whilst his mind is still in its most impressionable stage. Failing this, nothing is so likely to produce a powerful and life-like realization of the true facts of nature as the word-pictures of eyewitnesses. For this reason the writer of the present work seems to have acted wisely in culling, without pretence of originality, from many of the most accurate works of travel of modern times, and setting before her readers in detail the inferences to be drawn from the facts which she describes. 
Readers of more mature years can hardly fail to find in this volume some facts that are new to them, some suggestions of a wider interpretation of nature or of a more accurate perception of its inter-relations, or some fresh cause for intelligent wonder. If Newton could look on himself as a boy playing with pebbles on the shore of the great unexplored ocean of truth, every student of nature may well recognise that, whatever his years, his experience or his learning, he will remain but a student, and will never have learnt all that nature has to teach.

In looking upon nature as a great farm, there is, however, another and a more important lesson than any teaching of accuracy or of admiration. We read of steam-ploughs, of hoeing-machines and mechanical sowing, reaping and threshing machines; but, though much labour may be replaced by automatic processes, the controlling intelligence of the farmer co-ordinates all the operations of the farm to his one end. It is wisely said that

\section{'The undevout astronomer is mad,}

and Napoleon's tribute to the Higher Power, when he asked the sceptical members of his staff "Who made all these?' is only the natural testimony of intelligence. Truly those minds are to be pitied that fail to see more than the blind operation of mechanical forces even in the simplest of natural phenomena; but when these phenomena are studied separately, there is undoubtedly a danger that we may 'fail to see the wood for the trees.' When, hovrever, we contemplate the marvellous co-ordination of all the forces of nature, the balance of vegetable and animal life and their mutual dependence, we must be blind indeed if we refuse to look ' thro' Nature up to Nature's God.' 


\section{CONTENTS}

PREFACE

I. INTRODUCTORY .

II. PIONEER-LABOURERS

III. SOIL-MAKERS

IV. SOIL-CARRIERS

v. SOIL-BINDERS

VI. FIELD-LABOURERS

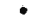

v

- $\mathbf{I}$

- 15

- 29

- 4 I

- 50

- 60

VII. FIELD-LABOURERS-continued . $\quad$ - 73

VIII. WATER .

1X. DESERTS

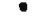

- 90

- 105

X. ROOTS .

XI. FOOD FROM THE SOIL.

- $\mathbf{I 2 4}$

- 139

XII. LEAVES AND THEIR WORK . . . 157

XIII. CLIMATE

- 177

XIV. BLOSSOM AND SEED

- 190

XV. THE GOLDEN RULE FOR FLOWERS -

- 208

XVL GUESTS WELCOME AND UNWELCOME. 


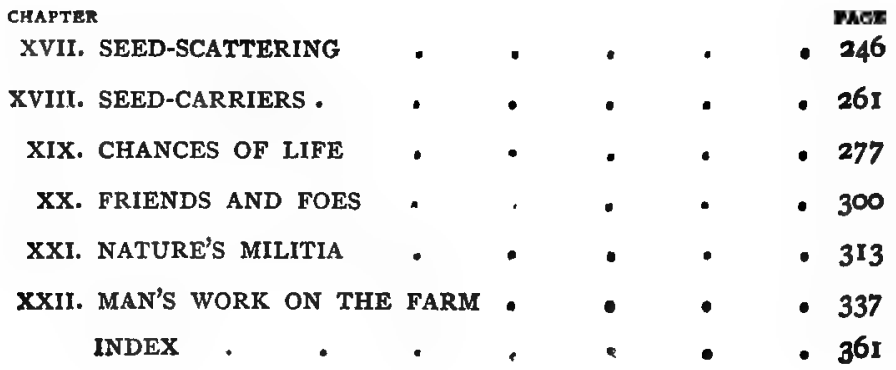




\section{LIST OF ILLUSTRATIONS}
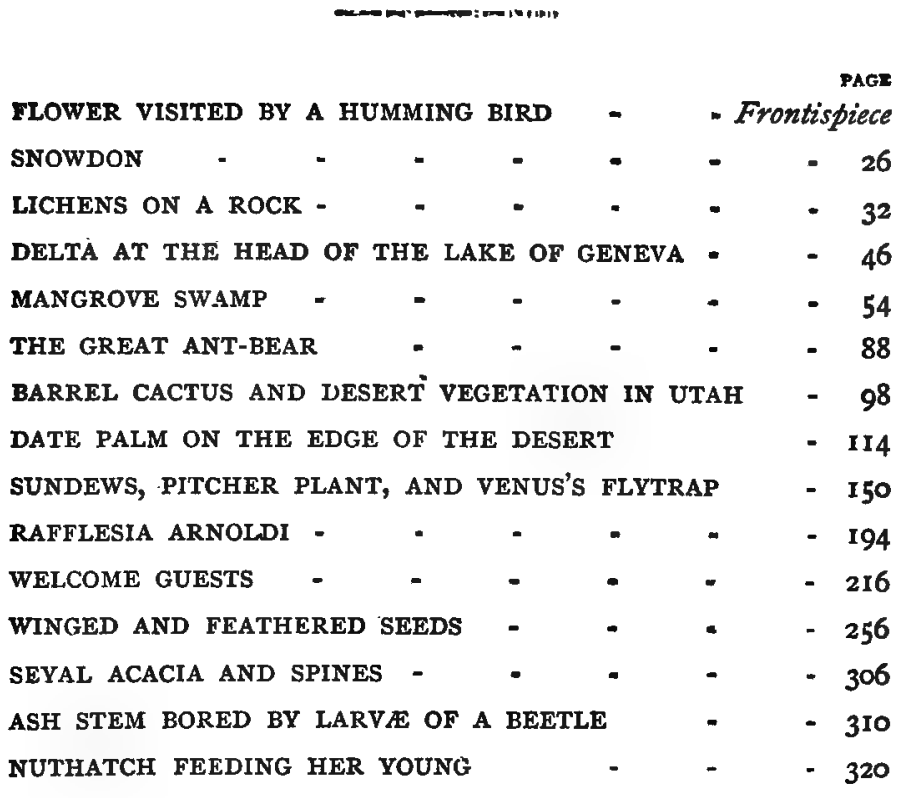

LONG-EARED OWL BRINGING FIELD-MICE TO HER YOUNG- 334 



\section{The Great World's Farm}

I.

INTRODUCTORY

WhAT would the learned writer of the old Eton geography, of sixty years ago, say to the statement that the whole earth is one great farm or garden, almost everywhere covered with vegetation, and 'bringing forth crops of the most luxuriant and varied kind'? This was certainly very far from being his own idea; for he informed his students that at least one of the 'quarters' of the world was little more than 'a vast sandy desert.'

Such was his description of the great continent of Africa, where, according to him, there was no cultivation, except in the immediate neighbourhood of a river or spring, "all the rest being one wide tract of utter desolation '; and he went on to say: 'These cultivated places, appearing like islands or oases in the great desert, caused some of the ancients to compare the whole continent to a panther's skin, dotted, as it were, 
with spots of fertility surrounded by a brown and burning desert.'

As a matter of fact, nothing could 'more wildly misrepresent the truth' than this description; but it was written before the interior of Africa had been explored, and the old geographers, feeling, it would seem, obliged to say something, were very much in the habit of writing 'desert' across those regions of the earth which were to them 'unknown.'

These imaginary deserts, which once occupied so large a space in our maps, are, however, fast shrinking and dwindling away before the face of the explorer, until there are few, if any, left. The last so-called desert in America was that to the west of the United States, and that vanished some five-and-twenty years ago, when Mr. Hepworth Dixon said of it: "It has retreated further and further, and has taken its last stand behind the Missouri, where I faced it, and now I can assure you that $I$ have been right through the Great Prairie, and desert there is none. The prairie is the pasture-land of the world' -all ready prepared, that is, to afford an ample livelihood to man's flocks and herds as soon as he should choose to make use of it; and certainly, therefore, no desert, though 'only an Indian hunting-ground'!

But still, it may be said, there is a wide difference between a desert and a farm. If the prairie is not bare, at least it is uncultivated; and the word 'farm' suggests the idea of ploughs and harrows, orderly crops, sheep and cattle. Very true; but because nature farms in ways of her own, on a large scale and without fuss, while man farms in his way on a small one, and lets all the world know what he is doing, is 
that any reason for denying to nature the name of 'farmer'?

How much of the earth has man brought under cultivation? In Europe, where he has done most, the proportion varies from little more than a twentieth (in Sweden), to a little more than one-half (in Belgium). Supposing that he farms, or 'improves,' one-tenth of the land all the world over-and he certainly does not do more at present-what becomes of the other ninetenths? It is not a desert, it does not lie idle; with but few exceptions, indeed, it is covered with crops of one sort or another; for the world is a green world, not a brown one.

But, where crops are grown century after century, millennium after millennium, no matter whether they be wild or not, there must needs be tillage, and that of the most thorough kind, fully deserving the name of farming, though it may be carried on without steel ploughs, and so quietly as to escape our notice.

There are vast pasture-lands here, there are extensive forests there; there are woods, jungles, heaths, moors, downs, but they have all been planted; and the soil was prepared in the first instance, and has been renewed since, by labourers who are not less truly deserving of the name of labourer than the ploughman, though they do not work with his implements.

When Captain, afterwards Sir Francis, Head, travelled goo miles across the Pampas, he saw to his surprise, first, I80 miles of the most luxuriant clover and wild artichokes; then an unbroken stretch of long grass, $45^{\circ}$ miles wide, without a weed; and finally, 
growing up to the base of the Cordillera, a grove of low trees and shrubs.

Man had had no hand in preparing the soil for this grass and clover, man had neither sown them nor cared for them in any way; yet there they were, just as good food for his cattle as if they had been grown on the most orderly of human farms. Surely, then, the lands of the Pampas had been 'farmed' most successfully, by one means or another. For the word 'farm' is said to be derived from an AngloSaxon verb which means 'to supply with food,' and certainly, in this sense, the lands which man still leaves to nature's labourers have every claim to be considered as one vast farm; for they grow, many of them, the most luxuriant crops, and they feed more live-stock than can be numbered.

Man grows for himself and his live-stock a few vegetables-about two hundred and fifty species-and he has adopted, and partly domesticated, about two hundred animals. But on the great natural farm things are done on a very much grander scale. Here the species of crops grown number not much less than a hundred and forty thousand; and the different species of live-stock amount to some millions.

With so many animals to feed, and so many crops to grow, nature's farm-labourers do not allow of 'deserts'; and wherever there is an unoccupied surface, they hasten to take possession, and if possible sow something upon it, if it be but a lichen. They sow even the little heaps of dust which collect in sheltered nooks, on the leads of the church-tower, on walls, in the angles of masonry, and make them bear at least a blade or two of grass, and often quite a crop 


\section{Introductory}

of various green things. Generally speaking, it is only by recent lava-fields, and the loftiest, bleakest peaks of rock, that these energetic labourers are baffled, and then it is only for a time.

Over and over again, as Mr. Ball says, he was told in different parts of the world that such and such a spot was entirely devoid of vegetation, or, in other words, a desert, and over and over again he found it to be quite a mistake. On the so-called 'bare' peaks of the Dolomite Mountains he always found a 'fair number' of plants hidden in cracks and crevices; even at Suez, on the exposed, burnt-up face of the mountain Djebel Attakah, he still found something, and in the northern part of the great Sahara, though vegetation. was scanty, it was difficult to find many yards together that were actually bare.

In fact, Mr. Ball had come to doubt the existence of 'deserts" altogether by the time he reached the 'rainless zone' of Peru, and was once more told that he would find no vegetation at all. Certainly this was more barren than any part of the world which he had seen yet, except indeed the drifting sands above Cairo; yet even here there were plants, stunted bushes in the gullies, and tiny vegetables in the depressions where the scanty rain rests longest; but they wanted looking for, as there was scarcely one so much as three inches high. The labourers had done their best; they had prepared the soil, and they had sown, but they had been hindered from growing anything like a luxuriant crop by want of water. And at one place, Tocopilla, they had been entirely baffled; for here at last $\mathrm{Mr}$. Ball found his desert-an altogether barren spot where not a single green thing was to be seen, and 
not so much as a lichen was to be discovered, even with the help of a microscope.

But this is quite an exceptional state of things, due to the extreme rarity of the rain; and such utterly barren surfaces are not only very few, but very small compared with the whole extent of the farm--mere spots, in fact, in the midst of generally luxuriant crops.

In most cases the so-called deserts are deserts only for want of water; the soil has been carefully made ready, and in the Great Sahara and the deserts of Egypt it is extremely rich, though at present covered with sand. What it might be, and how easily it might be made to 'blossom like the rose,' we can to some extent guess, when we find that the passing showers, which are all that visit the deserts of Egypt, are sufficient, scanty as they are, to awaken 'the green things on the yellow surface'; though we may well wonder how the seeds 'could germinate after months of exposure to the burning sun.'

And then, again, while it is quite certain that such vegetation as exists in these regions is grown entirely by the natural labourers, there seems also good reason to suppose that man actually does much to hinder their work.

If, for instance, man and his domestic animals were banished from the Arabian and African deserts, it is believed by Mr. Marsh that many parts of them would soon be covered with forests, and with forests would come rain, to the enormous benefit of the whole region. Acacias of several species are constantly being sown, and they sprout up plentifully around the springs and winter water-courses, while grasses and shrubs grow 
up under their sheltering shade. But these latter are mown down as fast as they grow by the hungry cattle of the Arabs; and even the trees do not escape, for the goat devours the seedlings whenever it has the opportunity, and the camel will bite through thorny branches as thick as the finger, and unfortunately it has a particular liking for the twigs, leaves and seedpods of the Acacia; so that between them, the tree of the desert has but little chance. If only they were left undisturbed for a few years these spots would be covered with groves, which would gradually extend where now little can grow but the foxglove and colocynth.

Still, even now, these deserts cannot be called bare, though their crops are scanty. As we have said before, the labourers on the great farm do not allow any surface to be bare, if they can help it, and they work as if it were their one object to grow as many crops as possible. The very snow-fields and ice-fields are not allowed to lie idle, for there is soil even here, and it must not be wasted.

Dust, meteoric dust from the higher regions beyond our atmosphere, is constantly falling all over the earth, to the amount, it is believed, of more than 500,000 tons every year; and though, being scattered evenly over the whole surface, it must be spread very thin indeed; still, where there is no other mineral matter, as on the snow and ice-fields of the Arctic regions, it is quite perceptible, and it is enough for the growth of such humble vegetables as the 'Red Snow,' which in summer covers the white surface with a flush of rosecolour many miles in extent. Nor are this and other similar minute plants grown to no purpose. These 
'barren fields' are also part of the great world's farm, an outlying part, it is true, where the produce is not large: but, such as they are, the crops are needed, for there are glacier-fleas and other live-stock even here, and these tiny vegetables supply them with food.

Nature's labourers are such zealous and thrifty husbandmen that they are always on the watch to occupy every inch of space where anything can be grown the moment it is vacated, and even before. They will overrun our gravel paths, and grow grass in our streets if allowed, and they will take but a very short time to convert the most highly cultivated garden into a wilderness without any trace of a path in it, if it be given up to them. This is true even in such temperate climates as our own, but in warmer latitudes the incessant struggle of the wild crops to invade and recover the ground which they have lost is still more marked.

At Pará, in Brazil, for instance, we are told that every lane, yard, and square is a battle-ground. Even the roofs and cornices of some of the public buildings are occupied by plants or small trees, which wave their feathery heads aloft like flags of triumph in defiance of the enemy. The city is hemmed in by a wall of tropical forest, consisting of giant trees, palms, and tangled creepers, which ever and anon send out skirmishers to try and effect a lodgment in the enemy's territory ; and so well do they succeed where circumstances favour them, that a large square, which was cleared and turfed, but left unguarded, was covered in five years' time with a tangled mass of vegetation fifteen feet high, and denser than the virgin forest. 
For there is no lack of labourers on the great rarm. They are employed by the million in all parts of it, and though they are always ready to reclaim any portion which has been taken from them, they nevertheless attend impartially to the whole -the small part which man has taken under his own care, as well as that which he leaves at present entirely to their management.

And a very sorry condition the human farmer's fields would be in if they were left to himself alone, in spite of all his improved modern appliances and scientific knowledge.

' It is an easy error to consider that he who has tilled the ground and sown the seed is the author of his crop.' And for the most part, perhaps, the farmer realizes but little of the vast debt which he owes to the unseen, unnoticed, and often abused labourers, who are incessantly at work for him.

Of course, he knows very well that he cannot do without sun and rain, and he will readily allow that dew, frost and wind are useful, and that at present he could hardly do without them; but grant him theseand what are they after all but labourers borrowed from the larger farm-and surely his improved ploughs and harrows, and his patent manures, will be able to manage the rest. In the days when a forked stick was the best plough, no doubt things were different, and the farmer was more dependent upon what the natural labourers were pleased to do for him, but now!

Well, let him try! There is an island just risen above the waves here, or there is a stream of cooled lava there-nice, fresh, virgin surfaces both of them, 
where nature's husbandmen have not yet been at work, so that he may keep either to himself, and show what he can do when he is not interfered with. Let him try his modern steel plough, driven by steam, too, if he will, upon either of these.

But there is no soil! Of course not; is the soil put ready for nature's labourers? Do they not have to make it, and out of these, or similar materials? But one cannot plough the bare rock, even with the help of steel and steam; and before these can do anything with it, it must be broken up and crumbled by other workers, much more humble and feeble in appearance, most of them absolutely noiseless, some quite invisible, and yet-far more powerful.

Wonderful things, no doubt, are being done with machinery, and the time may possibly come when we shall be able to grind up the rock without too great expenditure of time and labour; but even then, powdered rock is not soil, and will not grow any crop worthy of the name. It must be mixed as well as pounded before it can be converted into fertile soil, such as the farmer will find it worth his while to cultivate. And who is to mix it? It will not pay him to attempt the work himself on any large scale; but it has been done, and is constantly being done, on all parts of the great natural farm.

On the whole, then, the farmer will probably find it best, at least for the present, to accept what has been done for him, and to cultivate the soil which he finds ready made.

'Ready made ?' but doesn't he still have to plough 
it, and harrow it, and manure it? To be sure; but this is no more than has to be done, and is done, by the natural husbandmen also all the world over. Crops cannot be grown year after year, for many years in succession, without constant labour. For every crop takes something from the soil, and the loss has to be made good. The clods must be broken up, too, or the air and rain cannot enter freely, and the roots cannot make their way through the soil. And this the farmer must do as best he can, with his plough and harrow; but these are at best only clumsy instruments, and they are not enough by themselves. If the fields were deserted by the 'natural ploughmen,' the worms and others, the farmer would speedily find that his ploughs could accomplish only the rough part of the work. And it is much the same with the harrows; they cannot do the fine work of the great ' natural harrow,' the frost, which crumbles the soil grain by grain, till it is reduced to the condition of dust and ashes, ready for sowing.

And now surely the farmer may put in his seed and feel that if only seasonable weather be granted him he may be quite independent of further help from his humble fellow-labourers. The 'if,' to be sure, is rather a great and important 'if,' and altogether beyond his own control; but, granted the weather, may he not go on and prosper?

Not unless he is prepared to pay a whole army of boys to keep off marauders; and even then he would probably find himself worsted in the battle with slugs, and snails, and grubs, for these creatures have an especial fondness for seedlings, wild and cultivated. 
We are told, for instance, by the Rev. F. Morris, that out of 504 grains of rape planted as an experiment, 200 were eaten or injured. And how many even of these would have escaped if 'nature's militia,' the army of birds, had withdrawn their services? Very few, probably, for the farmer has not yet invented any satisfactory substitute, and if he be wise he will certainly welcome them in his fields, and be glad that they do not limit their care to the wild crops of the farm.

But when the crop has escaped these serious perils and dangers, what then? Even then the farmer will not in many cases have any harvest, unless nature again comes to his help and lends him a fresh set of workers different trom any hitherto employed in his service. This is especially true of the fruit-farmer and the market-gardener. The orchards and gardens may be a mass of blossom, but if they are left to themselves at this critical time there will be few apples, strawberries or raspberries, and absolutely no melons or cucumbers, no matter how favourable the weather may be. And the same holds good with regard to many another crop. Help is needed if they are to bring their fruit to maturity, and this help the grower is, generally speaking, quite unable to give. That is to say, he may be able to give it here and there in a few instances, but he would be powerless in an orchard, and would not be able to afford the time necessary to do the delicate work required in a single strawberry bed. Again, therefore, he must look to Nature's labourers for assistance.

Take the following example, for instance: In his 
garden at Santo Domingo, Nicaragua, Mr. Belt, the naturalist, sowed some scarlet-runner beans. The soil was good, and the climate was favourable to bean-life, and the scarlet-runners grew and flourished, and finally blossomed abundantly.

But it was finally! for here their career ended. They did not produce a single bean among them, simply because the right labourers were not at hand to give the requisite help.

The garden in which the beans grew had been recently taken from the forest, by which it was still surrounded; and that the labourers in this part of the farm were not idle was quite evident from the abundant luxuriance of the vegetation. But it was tropical vegetation, and as it did not include scarlet-runners, these were in the position of foreigners, whose appeals for assistance were not understood. It was in vain they put forth the bright flowers, which were wellknown signals in their native land, and would there have brought them the helpers they needed-no one noticed them. They were made welcome to the soil, the rain and the sunshine, and then they were left to themselves and their master, with the result already mentioned-no fruit!

And who were the gardeners whose absence proved to be of such vital importance? Humble bees, only humble bees! and, indeed, only the particular species of humble bees which wait upon scarlet-runners. There were plenty of others, but they did not understand, though very probably they would have come to do so in the course of a few seasons. As it was, however, failing these insect labourers, there was 
nothing to be done-nothing to take their place. Man has not yet discovered any substitute for the bee.

In the following chapters we shall consiider in more detail the various ways and means by which the work of the great farm is carried on by the natural labourers; and also some of the changes made in it by the work and unconscious influence of man. 


\section{II.}

PIONEER LABOURERS

No one needs to be told that all living things require food of one sort or another to keep them alive; but some people have fancied, even within the last hundred years, that vegetables had such delicate appetites as to need nothing but air and pure water for their sustenance.

If this were so, then, of course, one sort of soil would agree with them as well as another; and, in fact, it would not be wanted at all except as a protection to their roots, and as a means of fixing them to one spot and enabling them to stand against the wind.

As a matter of fact, however, no vegetables live upon $a$ diet of mere air and water.

But then, what of the seaweeds which float about in the ocean? Are there not vast meadows of weed far away from soil or even rocks of any kind? Does not the ocean, moreover, swarm everywhere, from the Polar regions to the Equator, with microscopic vegetables? and is it not a fact that no seaweeds, not even those which cling to the rocks, receive any of their nourishment through their roots, and therefore must live upon water? 
Quite true that they do not feed by means of their roots-indeed, no seaweeds possess true roots; and it is quite true, also, that they live upon what they obtain from the water, but surely the taste of it is sufficient to prove that it is not mere water.

There is no such thing as pure, absolutely pure, water in nature; and sea-water, which is much heavier than fresh water, contains thirty-five parts of solid matter in every thousand. The rivers are constantly pouring into it small quantities of every sort of mineral substance that can be dissolved, while the sun draws up from it almost pure water, leaving the salts behind to accumulate and help to feed the crops of seaweed, besides providing material for the skeletons of corals and sponges and the shells and bones of other seacreatures.

All plants, then-whether they tower aloft like the giants of the tropical forest, or send out streamers two or three hundred feet in length like the Giant Kelp of the Atlantic Ocean; whether they are so minute as to be altogether invisible to the naked eye, and whether they live in earth or in water-are alike in this, that they live upon other food besides mere air and water.

We may easily satisfy ourselves of this by burning a bit of wood, a few grains of corn, or any other vegetable matter. When it has burnt as long as there is anything to burn, and all the gases and water it contained are driven away, a small quantity of ash will remain, consisting of salts, or compounds of various metals. The whole amount is usually very small-so small that we might perhaps be disposed to think it could not be of any very great consequence. 


\section{Pioneer Labourers}

If, for instance, we were to burn a hundred grains of wheat so thoroughly that nothing but ash remained, we should find the whole amount of this to be equal to about two of the grains, or less; while if we were to take peas or beans, the amount in a hundred of each would be equal to less than three peas, and less than four beans.

There would be more in the straw or stems of all three kinds of plants, but still the quantity appears so small that one might doubt its being absolutely essential if one did not know that it was so.

However, 'many a mickle makes a muckle,' and when we consider, not single plants or a handful of grain, but a whole crop, the amount of mineral matter becomes large enough to look important. Thus, while a pinch or two of dust might represent the entire amount of ash of all sorts in a single turnip or carrot, there are, on an average, about 40 pounds of lime alone in 22 tons of turnips, more in proportion in the carrots, and very much more in an equal weight of clover.

The mineral substances chiefly taken up by plants are sulphur, phosphorus, silica, potash, soda, lime, iron, magnesia, manganese, together with mineral compounds of the two gases chlorine and fluorine. All these are contained in the rocks; but the question is, How are they to be made available-how is the plant to get hold of them? There is abundance of food, but as long as it is stored in the rocks it might as well be locked up so far as most of them are concerned, for they cannot get at it or make use of it. Of course; we all know that seeds cannot grow, though they may sprout, upon a slab of bare stone, even though it may be rich in the very food they want. The stone must be 
converted into soil before they can turn it to account; and how is this to be accomplished?

If man had to make his soil from the rocks before he could grow his crops, he would have to begin with crowbars and pickaxes, if he did not first resort to blasting with gunpowder or dynamite, and even then his progress would be slow and laborious.

Nature usually works in a much more quiet and unobtrusive fashion, but there are times when she, too, has recourse to blasting as a preliminary measure. She mines the rocks and shatters them by means of the earthquake, compared with which the power even of dynamite is insignificant; and if these rough measures do but little towards preparing the soil, they unquestionably make things easier for the army of labourers who follow.

But it is the noiseless and often invisible workers who accomplish most, for they are at work, some or other of them, incessantly during every moment of every hour, day and night, summer and winter, throughout the whole year.

Usually the first of the silent labourers to begin work upon the rocks are also the invisible ones-the gases of air and water, which wear away the very hardest rocks by degrees. They are not able to work equally fast upon all rocks, but where they can be employed, there the work goes on most rapidly. Those rocks which aro best able to resist them decay more slowly, even though they be actually softer and yield more readily to such labourers as wind and rain. In other words, the unseen chemical workers produce more effect on the rocks than do the seen, mechanical workers.

The two gases which do the chief part of the chemical 
work are oxygen and carbon dioxide, formerly called carbonic acid. Rocks containing much iron are especially open to the attacks of the one, and those containing lime, potash, soda, to the attacks of the other. We are all familiar with the fact that iron and steel become covered with rust if left exposed to the air. Keys rust if left in their locks, and even polished fireirons often rust in the summer, unless they are oiled or greased and so protected from the air. What happens in these cases is that the oxygen, always present both in the air itself and in the watery vapour floating in the air, lays hold of the metal and combines with it to form a compound substance-an oxide-which is looser and softer, and takes up more room than the metal alone. At first the rust is a mere reddish-brown stain; but as the oxygen eats deeper and deeper, and more and more oxide is formed, it swells up unevenly abovf the surrounding surface, and feels rough to the touch. It is so soft that it may be partly rubbed off by the finger, and when the rust is cleaned away there will be scars and indentations left, showing how much of the metal has been removed.

Now it would take a much harder blow to break a piece of iron than it would to shatter a flint; but if the two were left exposed to the air, the metal would waste away long before any impression was made on the stone.

Very many rocks contain iron, as, for instance, the slates, sandstones, granites, and basalts, some more, some less, but hardly ever in a pure state. The basalt of the Giant's Causeway contains so much iron that, on those sides which are most exposed to the weather, it not only looks rusty, but is also softer on the surface and less compact within, for nature's labourers do not 
generally work singly and alone, but in union one with the other, and the great ally of oxygen is moisture.

Let us take basalt as an example, and see how this rock is crumbled into soil. In perfectly dry air, at the ordinary temperature, oxygen is powerless to do even so much as tarnish iron in the mass, though it would have no difficulty in reducing it all to oxide-that is, rust-if the same mass of iron were exposed to its action in the form of powder. Fireirons do not rust in winter, or when in constant use, because the fire keeps them dry; they do rust when unused in summer, because natural air is never perfectly dry, even on the driest summer day, not even in the midst of the parching desert.

But, if iron quickly rusts when exposed to the damp air of such a climate as ours, we all know how much faster it does so when actually wetted; and therefore it is not surprising to find that basaltic and other rocks containing much iron decay more rapidly on the side which faces the rainiest quarter. Not that the force of the rain makes so much impression on them as on softer rocks, but that the wet enables the oxygen to work faster. The decay is not confined to the surface, moreover, for all rocks, even those which are most close and compact and are called impervious, absorb some amount of moisture, and this also finds entrance through the cracks and joints, from which no large mass of rock is ever entirely free. These joints are especially well developed in the basalt-an ancient lavawhich, in cooling down from the molten state, has shrunk and contracted into columns having from three to nine faces, and measuring from a few inches to several feet across. The rain, of course, easily finds 
its way in between these columns; but patches of wet and brown stains are also found actually inside the columns themselves, when these are broken open, showing that moisture has been sucked up by the rock.

Now, water in the natural state always contains some amount of air dissolved in it, and, wherever the water penetrates, there the oxygen of the air penetrates also, and lays hold of any iron that comes in its way, as we see by the stains that it has done in this instance.

The iron of the basalt is not, indeed, pure iron, being already combined with some amount of oxygen, but it does not acquire the reddish-brown colour of what we familiarly call "rust' until it has absorbed as much oxygen as it can hold. In this condition it is, of course, heavier, and, as we have seen, softer than before, and is therefore more easily washed or blown away from the surface. But it is also more bulky, and takes up more space than it did before, so that if it be formed inside the rock where it has not room to expand, the rock is cracked by it. This, of course, opens the way for more water and more oxygen to enter, and so the work proceeds, and the decay goes deeper and deeper.

We have chosen iron-rust as a sample of the way in which oxygen works because it is one of which we all know something, but it must not be forgotten that this is only one of many oxides formed in the rocks ; and that whenever oxygen combines with any other substance in a rock to form an oxide, it makes that substance take up more room than before, and so the rock is cracked and crumbled. The other gas, carbon dioxide, works in a different way, though it also helps the 
oxygen to rust iron faster than it could do alone. But when it works on its own account it is by combining with such substances as lime, potash, soda and magnesia, which it makes much more soluble than they were before.

Some rocks are said to be impervious, or 'waterproof,' but this only means that they allow water to enter so very slowly that, unless they are actually soaking in it for some time, hardly any is taken up. And so, in a similar way, some minerals are called insoluble, which again means only that pure water has very little effect upon them, dissolves them so very slowly that it hardly seems to do so at all. For some effect it has upon every known mineral, unless it be perhaps upon gold and platinum. But water in nature is never perfectly pure; how can it be, since it dissolves some, though it may be only a very minute quantity, of everything through, or over, which it passes? Its dissolving powers are greatly increased, too, by the addition of carbon dioxide-the gas we are now speaking of-which is being constantly produced both in earth and air, by the decay of vegetable matter in the one, and by the lungs of animals, fires and furnaces, in the other.

The rain, as it descends from the clouds, washes down with it some of this gas, and if it comes in contact with such a rock as limestone, soon makes an impression upon it. Chalk, limestone and marble, are all composed of carbonate of lime, softer or harder, the lime being already united with a certain quantity of carbon dioxide. But in this condition it dissolves so very slowly as to be called insoluble in pure water. When it comes in contact with the gas, however, 
whether in air or water, it takes up double the quantity it had before, and is converted into a double, or bi-carbonate, which is easily dissolved and washed away. Marble slabs which are exposed to the weather in such a climate as that of Edinburgh are completely destroyed in this way in less than a hundred years.

Even rocks which consist only in part of carbonate of lime are open to the attacks of carbon dioxide. For instance, there are the sandstones. The grains are hard enough, being composed of silica, and if they are cemented together with silica, too, the stone is one of the most durable that can be found, neither water nor gases, together or separately, being able to make much impression upon it. But if the grains are cemented together by iron oxide, or by carbonate of lime, it is quite another matter. Oxygen or carbon dioxide may get to work on the cement, and as that is removed the grains fall apart and become sand.

Then, again, there are the granites, composed of three minerals, quartz, mica, and felspar; the first is silica, like flint, and equally hard, and if the rock consist mainly of -quartz, as some granites do, it is of course extremely durable, for, besides resisting the action of the gases, it also admits very little water. If, on the other hand, the felspar predominates, the rock is softer, and water finds an easier entrance; but, besides this, the felspar-which is clay without the water, and in a crystallized form-contains either potash or soda, and often lime as well, and any one of these is easily attacked and made soluble by union with carbon dioxide. Once converted into carbonates, or bicarbonates, as the case may be, these are easily dissolved 
and washed away by the next shower. As for the single carbonate of potash, it does not need even a shower to help it, but melts away in the moisture of the air, as anyone may know who has ever tried to keep it wrapped in paper.

The carbonates being thus removed, and the clayey part of the felspar softened and washed away to form beds of clay elsewhere, the crystals of quart $z$ and mica must needs fall apart, and so the work of breaking down the rock goes on.

But nature's labourers proceed upon the principle that ' union is strength,' and they so constantly work in company that it is a difficult matter to apportion the result of their labours exactly each to each. We have already seen how water dissolves; we must now look at it in another capacity, and see how it acts the part of crowbar and pickaxe, and even at times of dynamite. A cubic inch of water, when converted into steam, occupies just 1,728 times as much space as it did before, and it expands with such violent force as to shatter the rocks beneath which it is confined. Such explosions as this sometimes occur during volcanic eruptions, water having found its way down through the earth till it has come into contact with some mass of molten lava, which has converted it into steam, and made it a powerful engine of destruction.

But water expands also, though in a less degree, when it is converted into ice, and it is under this aspect that we are most familiar with its doings. Ice occupies only one-fifteenth more space than the water from which it is formed, and, compared with the expansion which takes place in the formation of steam, this increase may sound insignificant. But its effects are 
very far indeed from being insignificant the force which it exerts being simply irresistible.

Water, as we have said, finds entrance everywhere, more or less, in one way or another, and wherever it is sufficiently near the surface to freeze, there it has the effect of a multitude of crowbars and chisels of all sorts and sizes wielded by an invisible army of workmen. It widens every crack in which it is formed, prizing up large masses of rock many tons in weight, loosening and eventually forcing them off, and also doing finer work, such as chiselling off splinters and particles of all sizes, large and small. The immense piles of rubbish which strew the surface of the glaciers, and consist of sand, grit, and fragments of all dimensions, are due mainly to the action of the frost, which in mountain regions recurs not merely every winter, but every night throughout the year.

Even in England, where frosts are less frequent, as well as less severe, and therefore penetrate to a less depth, the tops of the higher hills are often buried some feet deep with wreckage of the frost's making; only very often we fail to realize what is going on because the loosened fragments are being constantly washed away by the rain. In more severe climates the waste is immense, the hill-tops and mountains being crowded with great blocks and slabs wedged off by the frost; and this is the first step towards their being crumbled into soil. The more water a rock absorbs, the more easily, of course, it is cracked and splintered by the frost; and though we may not, many of us, have much opportunity of observing the work done in this way upon the rocks, we all know something of glasses and pipes cracked by the freezing of the water in them. 
We may have seen, too, how fence-posts are sometimes lifted out of their places, simply by the heaving of the soil beneath them; the water in the pores of the soil having frozen and swelled, and forced them up.

But even where there is no rain, and no ice can therefore be formed in their cracks and crevices, the rocks themselves feel changes of temperature; and where these changes are sudden, severe, and often repeated, no rock is strong enough to stand against them. The rocks of the Sahara and other similar regions are crumbled into sand simply by the intense heat of the day and the sharp frost at night. The one causes them to expand and the other makes them contract; and between the two the outer grains are being constantly loosened and forced out of their places.

When the 'Glass Road' was being made in the famous Yellowstone Park (Wyoming, U.S.A.), some huge blocks of obsidian, or volcanic glass, were found to come in the way; and as they were too hard to be either hewn or drilled, and could therefore not be blasted, the engineer in charge had large fires lighted on the top. When the rocks were scorching hot, a sudden deluge of cold water was poured upon them from the neighbouring lake, and by these means they were thoroughly shattered. This is of course a very extreme instance of the effect produced by changes of temperature, and such as would seldom, if ever, accur In nature; but it may serve to show how very real these effects are.

Of the other ways in which the rocks are broken up, it will not be needful to say much. We must pass over with brief mention the work done by sand, set in motion by wind or water, which cuts and polishes the 


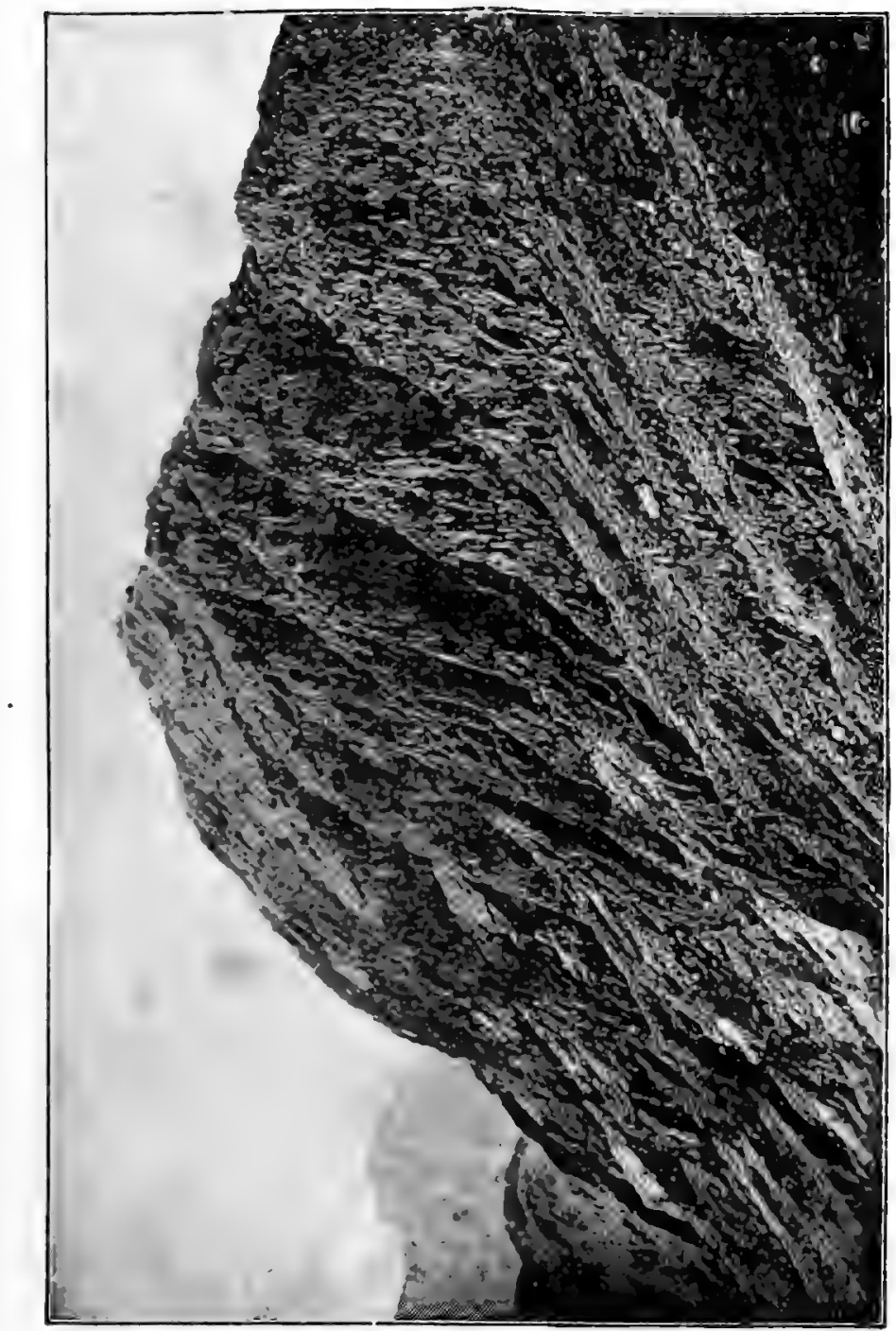



very hardest rocks when driven against them by the former, and, when driven by water, has produced the great cañons, or narrow gorges some thousands of feet in depth, with which we are familiar in California. Nor will it be necessary to dwell upon the hammering, battering effects of the rains, which are sufficiently obvious even in our climate, and are of course greatly intensified in tropical regions.

But a few words must be said about the glaciers, those frozen rivers, which are among the mightiest of nature's grinders. Looking down upon a glacier, and seeing it strewn with the blocks of stone and vast heaps of rubbish which have fallen upon it from the cliffs above, dislodged by the frost, we should be disposed to think it a very rough labourer indeed, merely engaged in carting away the wreckage made by others. But this would be a great mistake. A little brawling stream makes, it is true, far more noise and fuss, and even more show of work, as it rolls the pebbles over in the bed which it is perpetually deepening and widening; but the glacier is a giant mill-stone, pressing upon the rocks beneath with a power which is simply irresistible.

Glaciers move on in solemn silence, it may be at the rate of perhaps only an inch or two in the twenty-four hours, but they go on steadily and roiselessly, and as they go, they grind the rocks beneath to a powder so fine, that when at last it escapes from the glacier-mill in the stream, which flows out from beneath, it has been reduced to nothing but mud.

One other grinder, equally mighty and thorough, but by no means silent, must be mentioned in conclusion. This is the volcano, which, besides pouring 
forth streams of lava, often buries the surrounding country many feet deep in the finest dust and ashes, or in mud, if the eruption be accompanied, as it often is, by rain.

Such, then, are the principal pioneer-labourers employed in breaking down the rocks. By the combined efforts of the gases and moisture of the atmosphere, by heat and frost, wind and rain, by rivers and streams, by glacier and volcano, the rocks are gradually split up, worn away, and reduced on the surface to a condition of softness.

In tropical regions, where the air is always moist, and the rainfall large and violent, some rocks are decayed and softened to a depth of a hundred or two hundred feet. In drier climates, the work proceeds more slowly and to a less depth, the rock beneath being to some extent protected from the weather by the looser material above, when this is left to accumulate.

But the labourers which we have been thus briefly considering are only pioneers. They accomplish only the rougher work of preparation, and very much remains to be done before anything that can properly be called 'soil' is ready for the crops. 


\section{III.}

\section{SOIL-MAKERS}

STANDING before some bare expanse of hard rock, we might well wonder, if we knew nothing of the subject, how it should ever be converted into a surface fit for the support of vegetation. There may be vineyards close by showing that it has been done in other Instances; but what is to be the first step?

Ploughs, even steam ploughs, are quite useless here, and man must wait until the work is done for him, as it will be, and very thoroughly, too, in the end; but it will be done deliberately, without hurry or bustle, and it may take years or centuries. Meanwhile, it is of no use for him to look with longing eyes upon the rock; he can't plough it, and he would be mad to sow it, for any seed he could sow would be washed or blown away.

And yet if he were to look closely at the seemingly bare surface, he might, and in most cases would, find that it was not altogether bare and barren. He might need a microscope to show him the truth, but if he understood what he saw, he would discover that the rock had been sown.

The pioneer labourers, far from finishing, have hardly begun their work here, but seed has been 
scattered in this unlikely place; and if we look at what has been done in other similar places, we shall see that it has not been wasted.

Floating about in the air, invisible, but in countless multitudes, are-what answer to the seeds of other plants-the spores of those strange forms of vegetation called lichens, which, except in towns, are to be seen beautifying every old wall, roof, and tombstone. They are so light that they cannot settle at all, except when the air is still, and even then the least breath would disturb them.

But they are sticky, and this stickiness enables them to cling fast even to the bare rock. Once settled, they begin to grow, and are the first traces of vegetable life to make their appearance upon recent streams of lava. They may truly be called 'traces,' for the first-comers are nothing more than helplesslooking stains, or dust, hardly noticeable except by those on the look-out for them; and one would have said anything but dangerous to the rock, for they look not only perfectly inactive, but entirely lifeless.

Just so a stranger to the tropics, newly-arrived, would see with perfect unconcern a single small ant making its way across the floor of his room, a helpless insignificant insect, which he could crush with a finger. But the native knows better. He could crush the one, but behind it is a mighty column of ants two or three hundred yards long coming to take possession of the house, and there is nothing to be done, as he knows, but to give it up to them and retreat for the time. The ants come and go again when their work is done; but the lichens come to stay until displaced by other and more important members of the family, for they are the 
advance guard of the vegetable host, and their appearance signifies that the fate of the lava surface upon which they have settled is sealed. Nature has marked it for her own. She is going to break down the hard, barren surface sooner or latter, and convert it into a fertile, productive soil, fit for field or vineyard.

The lava has resisted for some time. For years it did not even cool, and it has scorched innumerable lichen spores to death in their attempt to settle upon it. Even when the surface had cooled there was for a long time heat enough within to dry all the life out of them; while multitudes have found the glossy surface too glossy even for their powers of clinging, and have been blown away as fast as they came. There are some streams of lava which are as glossy now as when they were first poured forth three or four hundred years ago, and no lichens have as yet managed to gain a footing there. But they are not generally kept so long at bay. They return to the charge again and again, helped by the pioneers who have also been at work meantime, and have gradually roughened the surface a little, or at least have taken off some of the glossiness; and at last the spores manage to, settle and fix themselves so firmly that neither wind nor rain can dislodge them, and they begin to grow and spread at their ease.

Then, in spite of what was said in the previous chapter, these vegetables, at all events, must live on air and water?

Not at all! Lichens are very substantial feeders indeed, and consume more mineral matter in proportion to their size than any other plants.

But if it is locked up, and not available until the rock 
is crumbled down and softened enough for the roots to penetrate into it, how can they get at it?

In one respect lichens are like seaweeds, for they have no roots through which to take up food. But they are unlike them in another, for they do feed upon the rocks; and even these first-comers, the humblest members of the family, mere stains in appearance, contrive to make a living wherever they can gain a footing. Not, of course, that they take up particles of stone, but, being all of them strongly acid, they are able to dissolve it first and then absorb what they need; and though they are at first so minute as to be almost microscopic, no rock can resist them.

The 'stains' spread and grow and decay, and by degrees there is formed from their remains a thin film of soil, in which lichens of a much larger growth are able to flourish. They are all more or less harsh to the touch ; and the ashy, steely grays, and rusty browns, and the brilliant yellow and orange of their colouring remind one more of minerals than of vegetables, which is not surprising, considering that often a fifth part of their substance, and sometimes much more, consists of solid matter eaten from the rocks.

When the lichens have had possession for a time, and have prepared the way, they are followed by mosses, which absorb much moisture from the air and help to decay the rock by keeping the surface damp, for, as we have already seen, where water is there frost and gases can get to work. The mosses grow and die in their turn, and their remains, with those of lichens and loosened particles of rock, as well as the dead bodies of such minute insects as may have found a dwelling among them, together form something deserving the 


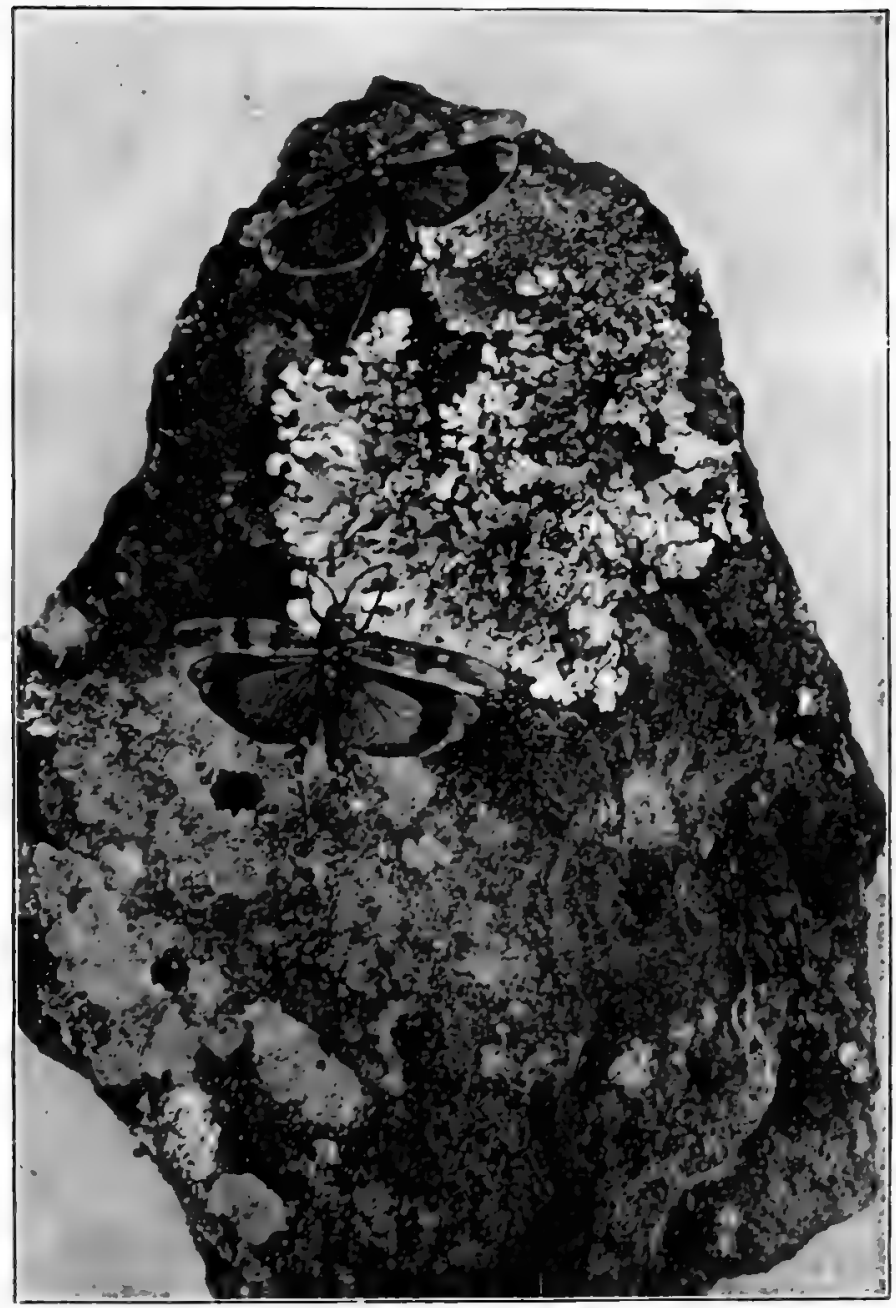



name of mould, which will support plants of quite large size. These are followed by dwarf shrubs, whose roots help on the work more rapidly; and in a century, more or less, the stream of lava is usually converted into soil fit for the planting of vineyards and gardens. *

Lichens attack not only lava, however, but also granites, slates, and even hard crystalline quart $z$-rock, wherever there is sufficient moisture. No rock is proof against them; almost any climate suits them, hot or cold, moist or dry, and they are the last signs of vegetation to be lost sight of by the mountaineer as he ascends towards the region of perpetual snow and bare peaks, whither even they are unable to follow. But they flourish best and do most work where there is moisture.

They quickly make their appearance upon any freshly exposed surface of granite, though we may often need a microscope for their detection. In one instance, at least, however, their brilliant colouring and, what is more unusual, their sweet scent betray them.

The so-called Violet-stone found on the summit of the Brocken is nothing but bare granite, covered with a film of what looks like scarlet dust, which smells like violets, especially on being rubbed. It looks so perfectly harmless, that one can hardly believe it possible it should affect the solid granite in any way. Yet it does; to a very small extent, indeed, but just sufficiently to prepare the way for two large brown lichens, which are the next to make their appearance; and then the work proceeds more rapidly in the way already described, until at last tall pine-trees rear their heads, and find sufficient food and foothold, where but a few years before there was nothing but a bare surface. 
The pines are much more imposing in appearance, and look capable of much greater exertion (as they are in some ways), but they could not have done what the lichen does ; and, but for the lichen, they could never have grown here at all.

We see, then, that nature makes large use of the humbler vegetables in preparing the way for the crops which are eventually to be grown; but it must not be forgotten that the process of preparation is an exceedingly complicated one, performed, not by one set of labourers, but by many, all working together.

Even a very scanty covering of vegetation does something, it is true, to protect the rock below against the battering of the rain and against changes of temperature; but, on the other hand, it keeps the rock damp, and moisture not only dissolves on its own account, but attracts gases from the atmosphere, which greatly increase its powers in this respect. Then, too, the powerful gas, carbon dioxide, is also formed in the soil itself by the decay of vegetable matter, besides being given off by living roots, and this greatly enhances the dissolving power of water.

Lichens, as we have said, are able to eat into the rock, as oxygen eats into iron, and by similar means, for both are strongly acid; and on removing lichens from a stone one sees indentations, similar to those left on a piece of iron by the removal of rust. But what is true of lichens is true in a degree of all plants. The roots of all plants, that is to say, are acid, though in a less degree, especially the young, fine, hair-like roots; and if these find their way through the thin soil to the rock beneath, they eat into it, leaving a distinct impression of themselves 
upon it when they are removed. The finest hair will leave its mark.

The amount of acid contained in a delicate little rootlet, or even in a lichen, is, of course, very smallquite insufficient, one would say, for the work it has to do; and so it is in our hands. That is to say, if we get from the chemist and apply the self-same acid in similar quantities, we cannot do with it what the lichen and other plants do; we cannot make as much impression upon the rock. For the lichen, though it may look dead, is alive, and the roots are alive; and living things, however humble, produce wonderful effects, such as dead matter never can.

But roots also exert a powerful influence upon the rocks in another way. A very common method of breaking up the rocks in use with quarrymen is to drive into them plugs of very dry wood. These plugs are then watered, whereupon they swell with such force as to split even the hardest granite. Roots act in a similar manner, though less violently; and by swelling in every direction, they gradually widen any cracks into which they have found their way, and actually wedge off large slices from the sides of hills and cliffs.

In the neighbourhood of Mount Etna people make the roots of the prickly pear work for them in this way, for they want to hasten the breaking up of the lava, in order that they may turn it to account as soon as possible. The lava cracks as it cools, and in every crevice that appears they insert a branch of this cactus, which not only lives, but soon begins to grow, thanks to the warmth, sunshine, and moisture of the genial climate. Its roots cannot, of course, penetrate the lava, but they can and do make their way into every 
crack and cranny within reach, and as they grow and swell they break up the rock into fragments.

As to what the plant lives upon in the absence of soil, it must be remembered that often a very little mineral food is enough for a plant, if only it is able to make the most of what there is and has plenty of water; then we must remember, too, that lava is especially rich in the materials required by plants, and that water flowing over it, or draining through it, would certainly dissolve some of these materials and bring them within reach of the roots, which would obtain them in this way quite as well as from soil; and then, finally, the whole cactus family, like the lichens, are furnished with large quantities of acid, by which they take up an altogether unusual amount of mineral matter, and they are apparently able to take it up, as the lichens do, from the solid substances, at least, to some extent, for in their native land, America, they are to be seen growing out of the rocks.

Though we may not have had the opportunity of noticing how roots split the rocks, we are all probably familiar with the power which they exert on a smaller scale and upon humbler material. Who that has ' gardened,' even to the extent of growing a few ferns, but has some time or other known a pot cracked by the efforts of the roots to find room when they have outgrown their domicile?

But we have now to consider other means by which nature prepares the soil. Hitherto we have confined our attention to what is done with the rocks on the spot, the soil being left where it is made; but this proceeding is attended by certain disadvantages : the soil 
rarely attains any great depth, for one thing, as the rock below is protected more or less from frost; and then, again, generally speaking, one kind of rock alone does not contain all that is necessary to make a really fertile soil rich in all the various mineral matter required for luxuriant crops. If we look at those soils which are acknowledged to be the richest in the world we shall find that, as a rule, they have been much mixed. We say, as a rule, because most of the lavas are rich enough in the minerals which plants require, and are also so well drained, thanks to the cracks and fissures within, that they do form most productive soi] when simply crumbled down.

With the granites, however, the case is very different : they are poor in the necessary minerals to begin with, and what they do possess is, as we have seen, dissolved; and in great part washed away. Granite slopes are poor and sandy, therefore, while the clay deposited at their feet is too stiff and compact to be fertile; and nature seems to tell the farmer as plainly as she can that in most cases he will not find it worth his while to try and grow wheat either on the hills or in the dales of a granite district. Of course, where granite decays on the level, and its various minerals remain, all crumbled down and mixed together, it is naturally more fertile than where the best of them are washed away; and thus we find that the granite soils of the Scilly Isles are far more productive than those of the Scotch hills, and are capable of bearing good crops of corn, in part, at least, because less of the potash has been washed away from them. But some thanks are also due to the more genial climate, for on the granite highlands of Dartmoor 
there is no vegetation but heath and coarse grass, and though one has heard of labourers attempting to cultivate portions, and not without some success, it is impossible to say that the soil is naturally adapted for either field or garden crops. The moor is flat enough, indeed, to prevent the separation of the sand and clay, and such minerals as the granite possesses are fairly enough mixed without much loss by washing; but the natural poverty of the rock is aggravated by its elevated situation on the one hand, and by the shallowness of the soil on the other, and the soil therefore labours under the two great disadvantages of a cold climate and want of drainage. To the latter of these are due the many bogs which abound, not only on Dartmoor, but on the granites of Scotland, and the serpentine rocks of the Lizard as well-everywhere, in fact, where the soil lacks depth and the underlying rock is so close and compact that water collects on the surface instead of draining through.

These moorlands and bog-lands are accordingly dubbed 'waste' by those who look at them only with the eye of the farmer, and are reckoned among the twenty odd million of uncultivated acres in Great Britain, thirteen million of which are pronounced altogether irreclaimable.

Waste lands! because the farmer cannot profitably bring them under his plough and harrow! as if that were the only end for which soil could possibly be wanted, and as if man and his domestic animals were the only creatures requiring to be fed. Waste lands! where grouse and black game feed upon the heath buds, where bog and moor are the summer haunt of curlew and plover, not to mention the countless other 
feathered fowls, not classed as 'game,' which yet form part of the live stock for which nature grows the varied crops of the 'great farm.'

The soil of the chalk-downs is like that of the granite table-lands in one respect, that it is derived chiefly from the rock beneath, and has had little advantage of intermixture with others; but-and this makes a vast difference-the underlying chalk absorbs water readily, like a sponge, so that bogs have no chance of forming. The downs grow excellent pasture, and are especially adapted for sheep-farming; but if people will plough up the soft fine herbage of nature's providing and try to grow corn and turnips instead, they must not be surprised if they get poor crops in return for much labour. The soil wants mixing before they can be grown to much purpose; and since the other minerals necessary are not upon the spot, the farmer must fetch them from a distance before he can grow a satisfactory crop-and this is expensive.

But nature has labourers at her command who can do what the farmer can never accomplish, no matter what his wealth and appliances. Nature's soil has been transported wholesale, not once only, but over and over again, and has become so much mixed in the process that no soil is absolutely pure, even though it be produced by the crumbling down of one kind of rock only. For every rock that meets our eyes was formed from others more ancient still.

Most of the richest soils of the world have been mixed, either by the work of rivers, or by that of other labourers to be considered by-and-by. And besides being mixed, they have in many cases been transported' from situations where they were comparatively useless, 
to others where their good qualities can be turned to the best account.

The richest soil in the world is of little use on a lofty mountain-top, for none but lowly plants can stand the cold and exposure, and anything to be called luxuriant vegetation is impossible. Take even the case of the Cheviot Hills. They cannot be called lofty, but their more elevated parts are too exposed, too bleak, for successful cultivation, in spite of the rich soil, which would be invaluable for farming purposes if it could be transported to a more genial climate. To yield its full value, this soil must be brought down to a lower level, and for that we must wait nature's time.

But in numberless other instances this is what has been done. Soil has been brought down from the mountains, where it must have been comparatively unproductive; it has been mixed and prepared, and finally spread out in extensive fields ready made to the farmer's hand, in situations where his crops can have the warmth and moisture which are essential to them. - It certainly does appear perverse, therefore, that men should persist in trying to grow crops where they seem plainly meant to feed their sheep; and that they should want to plough up moors and deer-forests which could never make productive fields, when by long and most elaborate preparation thousands and millions of acres have been provided which would yield abundant harvests with less than half the labour. 


\section{IV.}

\section{SOIL-CARRIERS}

WE have now seen by what means the rocks are crumbled -down; but in many cases much besides crumbling is necessary to convert rock into good soil. On a bleak hill-top the crumbled materials will be of little use owing to the climate, though they may be most valuable when brought down to the lowlands. But, more than this, nearly all the soils which we look upon as especially fertile have been made so by being mixed. We have now to see how this mixing has been effected, and how the crumbled matter of the rocks has been transferred from one place to another.

When we consider which are the best corn-producing regions of the earth, our thoughts naturally turn first to Egypt, once the granary of the world.

And what is Egypt? 'The gift of the Nile,' as the ancient historian says. The soil which produces such wonderful-crops has not been produced by the decay of the rocks upon which it rests, but is a mixture of soils brought in great part from the lofty mountains of 'Abyssinia, hundreds of miles away.' The only fertile tracts in Abyssinia itself are due to the sediment washed down from these mountains, which are rich in the minerals most desired by plants, but, like the 
Cheviot Hills already mentioned, unproductive, owing to their height and the consequently severe climate.

The top of this magnificent chain of mountains is a vast table-land, upon which the rains descend heavily and incessantly during some three or four months of the year, the fall being so abundant as to supply five tremendous mountain-torrents, which rush down the sides of the mountains with the force of cataracts, and carry with them enormous quantities of rock, which is ground up by degrees into the finest mud and poured into the Nile. The river rises so much in consequence that it overflows its banks, inundating the plains of Lower Egypt during four months of the year, and wherever the flood comes, there it leaves behind it a thin film of rich mud, which needs but little labour on man's part to make it produce most abundant harvests. So large is the amount of sediment brought down by the river-which those who like statistics may be interested to know is about equal in bulk to a solid cube measuring more than five feet each way transported in every second - that the river-bed is gradually rising, and the inundation therefore extends further and further; and very, very slowly, but still surely, more of the desert is being converted into fruitful soil. Left upon the Abyssinian mountains, the materials of which this sediment is composed would have had little or no value -for man's purposes, at least-but, transported to the magnificent climate of Egypt, and mixed with other matter, they form a soil which is the very perfection of fertility.

The sediment is not all deposited on the land or in the river-bed, however; much is carried into the Mediterranean, where another delta is being gradually formed, 
equal no doubt to the old one in richness, and capable of bearing crops as abundant, should it ever rise above the waters. A delta is possible only where there is little or no tide, or current, to carry the sediment away.

But it must not be forgotton that something more has been done than merely to transport this wonderful soil. It has also undergone much mixing, and consists not only of mud washed from the Abyssinian mountains but of sand, which is blown into the river in vast clouds from the desert. The Nile itself, too, has done a great deal of grinding, and sand- and mudmaking, as well as its tributaries. Sand, driven by water, will wear away the hardest rock by degrees; and by means of the sand which the wind blows into it, the river has cut its way through the rocks, scooping out for itself a wide deep bed. The solid mass of rock thus removed, grain by grain, has also contributed in no small degree towards the formation of the Great Delta.

But even this is not all. No soil can be really fertile, however rich in mineral matter, unless it contain some amount of animal or vegetable matter. And this, too, has been supplied to the Delta in an interesting and remarkable way.

Nile-water, like that of all rivers more or less, contains a vast number of microscopic animals and vegetables, the lowest and simplest forms of life, which are not only left behind with the mud, but are killed in myriads where they come in contact with salt water. The Mediterranean being a tideless sea, this wholesale destruction cannot take place except at the mouth of the river, and for a certain distance beyond it in the 
sea. Fresh water being lighter than salt, flows over the latter at first, before the two mingle; and, as seawater abounds in these minute forms of life to a much greater extent than river-water does, and as fresh water is as deadly to the one as salt to the other, the destruction wherever the two come in contact must be wholesale.

At present it is the delta of the future which chiefly. benefits; but the present delta was slowly formed in like manner under water, and has therefore received an abundant share of this fertilizing matter in ages past, some amount of which is also brought and left with the mud every year.

But where rivers are affected by the tide, there the salt water flows up under the fresh, for many a mile above their mouths, carrying with it a living freight, which must to a large extent perish and be left behind; while the microscopic inhabitants of the river-water are destroyed with equal certainty wherever they come in contact with that which is salt, or even brackishthat is, partially salt.

Hence the great fertility of large districts on both sides of the Thames, at the mouth of the Humber, on the shores of the Wash and Bristol Channel.

The remarkably productive 'carses' of Scotland owe their fertility to the same apparently insignificant cause; and the soil of Holland is rich for similar reasons, having been to a large extent formed by the Rhine, Meuse, and other rivers.

The whole of Southern Louisiana, with its extensive cotton and rice-fields, was made in like manner by the Mississippi, which becomes a deuse yellow torrent after it is joined by the Missouri, and brings down 
with it a heavy load of mud, ground from mountains 3,000 miles away, which it has deposited in some places to a depth of 300 feet.

And so again, on a smaller scale, the low plain at the head of the Lake of Geneva is formed of mud from the mountains, which the Rhône has brought down and deposited in the lake, adding to it year by year, until it has risen above the water, and Port Vallais, which stood on the margin of the lake in Roman times, now lies a mile and a half inland.

Inundations are caused usually either by excessive rain, such as that which falls periodically in Abyssinia, or by the melting of the snow in spring; but passing mention must here be made of certain inundations brought about by very different causes, and which, though on a very much smaller scale than these others, are yet said to have altered some of the valleys of North America to a quite incredible extent.

These inundations have been caused by the beaver. The beaver is retreating further and further before man; and though it still inhabits the North of Europe and Asia, it is nowhere now so plentiful as here in North America, where, also, the effect of its work in the past may best be observed.

But the beaver once abounded in England and Wales, and indeed throughout the greater part of Europe, as the names of many places, such as Beverley, Beverstone, Biverbike, and many others, plainly show. What we see of its work in America, therefore, is probably only a specimen of what it has done wherever it has been undisturbed. Here, at all events, thousands of acres of land have been submerged, at one time and another, as the result of its 
labours. As is well known, the beaver is in the habit of building dams; and these are often so solid and extensive as to stop up the streams and rivers in which they are constructed, causing them to overflow and form shallow lakes.

But local floods were only the first result of its work; for the streams brought down with them the usual sediment, which was spread over the inundated surface, gradually raising its level, until the lake became a marsh covered with marsh-plants. Then, as the sediment still accumulated, the marsh-plants by degrees. found the situation too dry for them, and died off; their places were then taken by grasses, and the lakes were thus converted into meadow land, fertile, as river-formed soils usually are, and enriched by the decay of the marsh plants.

The value of river-mud is abundantly seen in Egypt ; and in Hungary the broad river Theisz is left uncontrolled by dikes in its upper part, because the yearly spring-floods which lay the whole neighbourhood under water, though inconvenient, are found to be of such great benefit to the soil.

Rivers, then, must be reckoned among the most important makers and carriers of soil. But the wind, too, does much good service, though also occasional damage, from man's point of view, as nature's labourers are apt to do, in these disorganized days.

On the Lincolnshire Wolds, for instance, and on the coast of Norfolk, where the soils are light and sandy, the whole of the finer portion, as well as the seed sown, is sometimes altogether blown away by the equinoctial gales. One field near Cromer was sown three times in the course of a single spring, and was finally left to 


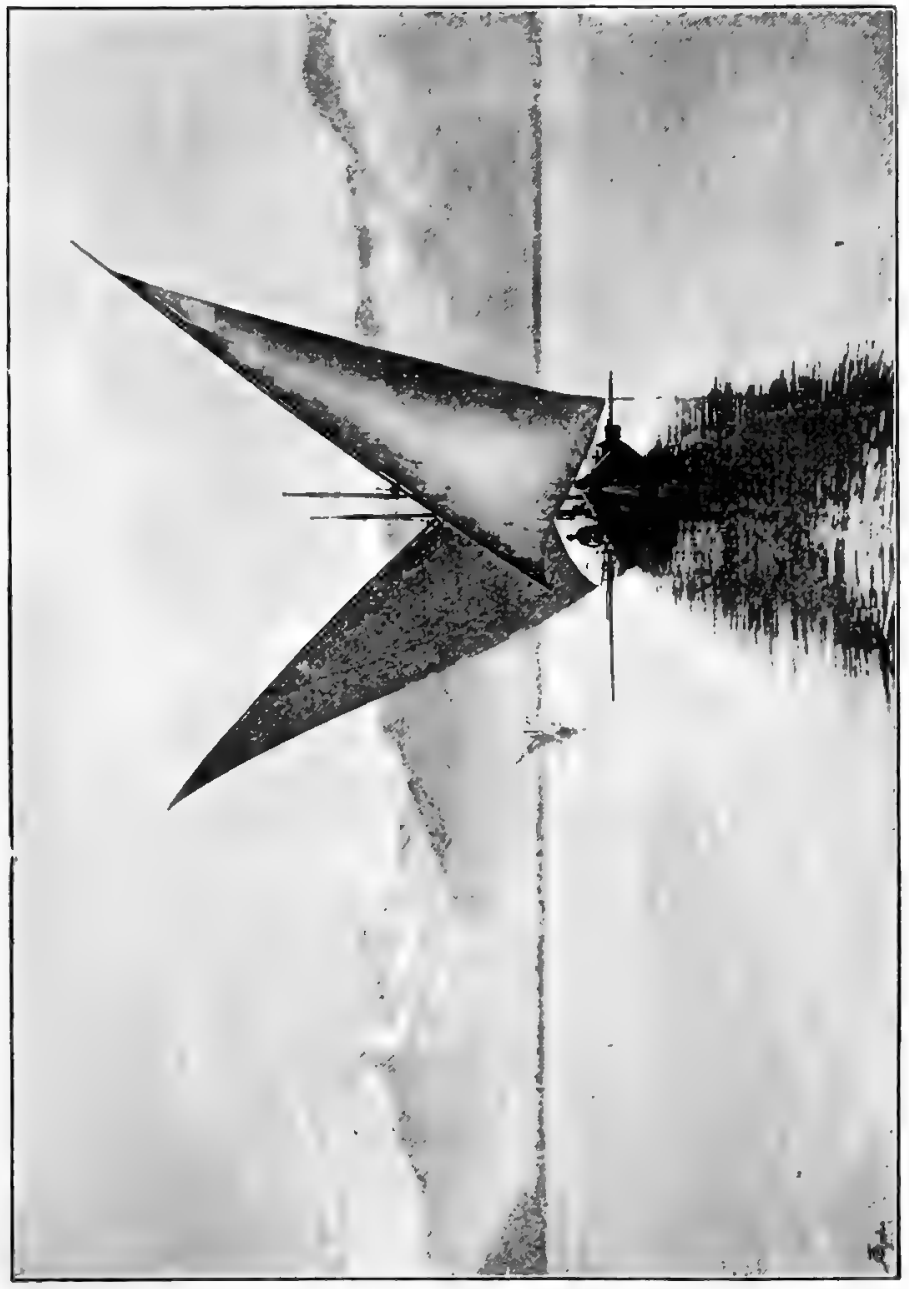



itself, all the upper portion of the soil being banked, like a snow-drift, against the hedge.

But for the hedges the wind would no doubt have spread the soil fairly over the neighbouring fields. Its efforts on this occasion were, however, certainly misdirected.

But when the wind is able to raise dust from the fields high in the air, as it does at times, it may carry it great distances-miles, and even hundreds of miles -and so do real service to the soil elsewhere.

There is naturally most dust in winter and early spring, when the fields are bare, more or less, and especially during the dry March winds. Clouds of dust are raised from ploughed land, and in dry weather even from grass-land. Large quantities are transferred in this way from the high lands to the lower.

But dust may be blown uphill as well as down, and it may be carried over dry sands, or absorbent rocks, where water would be sucked up so quickly as to be of no use as a carrier.

It has been suggested that much of the fertility of our own land may be due to the east wind, for which few people have a good word to say. The east wind is a dry wind, and undoubtedly a dusty wind, as we know it ; but when the climate was colder it must have been sharper, and drier, and dustier still ; and it may well be, therefore, that it has helped to bring about that mixture of the soils to which they owe their fertility.

As to the enormous distances which fine dust is often carried, we have positive proof in the brick-red or cinnamon-coloured sirocco dust which falls thickly upon vessels in the Atlantic at certain seasons of the year, and is carried to Europe as far inland as the Tyrol. 
This dust, which is exceedingly fine, has travelled thousands of miles on the wings of the wind, the greater part of it having been borne across the Atlantic from the banks of the Orinoco and Amazons. Its value as a fertilizer is recognised by the North American farmers, who use a similar deposit of 'flint-earth' to mix with some of their heavy soils. Very fertilizing also must be the volcanic dust, which, being carried high up into the air, at times probably far above the cloud-region, is conveyed enormous distances before it finally sinks to the earth.

The most tremendous volcanic outburst on record is that of Krakatoa in 1883 , when millions of tons of matter were hurled into the upper air, and dust, to the depth of two inches, fell a thousand miles off. The vegetation of the neighbourhood was, of course, utterly destroyed, being deeply buried in ashes and pumice-dust; but the great farm is so extensive that occasional ruin here and there is of little moment compared with the benefits which follow in the long run, especially when the ravages made are so quickly repaired as they sometimes are. In this instance it took less than five years to cover up the dismal scene of desolation with a fresh growth of tropical luxuriance. Just so Vesuvius is said to smother and destroy the crops in its neighbourhood every eighth year; but it is this very fact which makes the soil so wondrously fertile during the other seven.

However, we are concerned just now chiefly with the work done by the wind, and must glance at one curiously interesting sample of it which has been observed in the valley of the Limagne, in Auvergne. Here there is no active volcano to furnish dust, and 
yet the fields seem to get it-and that, too, without the drawback of being suffocated every few years. Where does it come from?

The wind blows chiefly from the west and southwest, across the mountain-chain of the Dômes. The air on the western side of the mountains is bright and clear, but that on the Limagne side is generally slightly hazy, and the haze seems to consist of fine dust. And when we inquire about the mountains, we find that they are extinct volcanoes, and are widely strewn with volcanic ashes, the relics of ancient eruptions, rich in the minerals which make the most fertile soils, and just in the condition in which plants can most readily make use of them.

It seems, therefore, that the inexhaustible fertility of the Limagne is in great part due to these constant supplies, which are carried across the country by the sometimes severe wind, and naturally fall when it subsides, besides being brought down by rain and snow.

The English proverb declares that 'a peck of March dust is worth a king's ransom,' and there can be no doubt that the clouds of dust blown upon the fields from the high-roads are most valuable. So, too, in spite of all their drawbacks, are the dust-storms which occur from time to time in certain regions-as, for instance, in Western Iowa, where the air is filled for days together with dust of the finest description. 


\section{V. \\ SOIL-BINDERS}

THE materials being ground up, mixed, and in some cases transported, there are still two important matters to be attended to before anything strictly to be called 'soil' can be formed.

First, these materials have to be bound to the spot where they have been deposited; and, secondly, before they can grow any but poor crops they in many cases need the addition of animal or vegetable matter.

Nile-mud, and river-mud in general, already contains some proportion of this, and does not consist of mineral matter only.

But the first thing is to make the future soil settle down, since nothing of value can grow in a wandering sand-drift. The deposits, whatever they be, need protection against the washing of the rain and the drying of the wind, which will not only dry the surface, but blow it away in clouds if it is left exposed.

Even to this day the plains of Hungary suffer from dust-storms, though they have long been covered with vegetation; and we may easily imagine how much 
worse these must have been when sun and wind had full play, with nothing to check them.

It is clear, too, that where sand or volcanic ashes have been brought by the wind, the same wind may in many instances scatter them again. And where mud has been brought down by a river and deposited within reach of the tide, there it will be liable to be washed away, unless some means be taken to fix it to the spot.

Let us even look, for instance, at a railway embankment. It has been piled by human hands with a special object, and is a far more solid mass than if it had been merely blown together; but yet it to some extent wastes away. Its bare, exposed surface is washed and wasted by the rain, dried and blown away by the wind; for there is nothing to protect it from either, to begin with. But this state of things does not last long. There is always plenty of seed floating in the air, ready to sow itself on any bare space it can find; so that in two or three years' time the embankment is overgrown with grass, whose roots are so matted together that further shifting of the soil is to a large extent prevented.

Of course, where seed is sown even before the soil is made, as we have seen in the case of lichens, there the mould as it is formed is kept in place and protected, and is able to deepen undisturbed. But where sand has been heaped together by the wind, or mud deposited on the coast, there something is needed to give it firmness, or else it will be dispersed again.

The sandhills on the plains of Venezuela, for example, are still constantly moving to and fro, here to-day and there to-morrow, except in one district where they 
have been consolidated into a low range of permanent hills by a curious grass with tall, cutting, sword-edged blades, which grows so closely and with such rapidity that any paths made by travellers are quite covered up and destroyed by it in a few days. In itself it is of no use-that is, it cannot be used as fodder for flocks or herds, though no doubt it affords shelter, and possibly food, to wild animals; and where it grows, there other more useful plants have no chance, being simply overpowered and choked by it.

But then useful grasses and other fodder-plants would be quite unable to spring up while the sand was shifting about; they could not grow fast enough to stop it from smothering them. Their turn may come by-andby, when generations of this coarse grass have improved the soil.

The plants which are most useful for this work of binding the soil and giving it its first firmness are those which, besides growing quickly, also send out especially long roots, runners, or underground stems, often miscalled roots, which are pegged down at frequent intervals by real roots, much in the same way as the thatcher binds down the straw on the rick-top. The couch-grass and others have long underground stems of this sort, as the gardener knows to his sorrow; and then there are the bindweeds, most appropriately so named, for they send out long, trailing runners aboveground, having roots at each joint, which make them extremely difficult to get rid of when once they have established themselves in a garden. Their tropical relatives, the ipomæas-plants of much larger growth, but bearing similar convolvulus-blossoms of more brilliant colour-are among the plants which render most 
useful service in the Bermudas by stopping the fine white coral-sand of the coast from invading and burying the neighbouring gardens.

Plants of the convolvulus family are equally useful on the coast of Ceylon, where the rivers, flowing rapidly down from lofty hills, bring with them heavy loads of sand and mud. Under ordinary circumstances, since the Bay of Bengal is not, like the Mediterranean, a tideless sea, these would be carried away and deposited some miles from the coast. But this is prevented by the ocean-currents, which set towards the island, and not only drive back what the rivers bring down, but add to them similar loads of their own. Accordingly, the sand and mud of the rivers, unable to escape further, are piled up in bars along the shore, and these, when once begun, rapidly increase in size until they rise above the water, and form long embankments reaching for many miles, with the river flowing behind, and occasionally bursting through them.

These bars, though a mile or two and even more in width, are not very solid at first, but they are presently sown with such plants as do not mind salt water, and the roots soon penetrate and mat together in such a way as to prevent the soil being washed away. The drier sand on the top of the bank is protected from wind and rain by creeping plants, among which is one of the great bindweeds already mentioned, which covers the surface down to the water's edge, with its long, trailing branches pegged down at each joint, as already described.

When the sand has been consolidated and improved by the growth and decay of these and such-like plants, 
there follow shrubs and small trees, such as do not object to the saltness of the soil ; and finally, when the way has been carefully prepared, the once barren sand-banks are covered with groves of coco-palms. It is a fact never to be lost sight of, that here, as so frequently elsewhere, the first all-important work is done by comparatively feeble instruments; the dustlike lichen prepares the way for the pine, and the insignificant salt-worts, and weak-stemmed, creeping bindweeds make ready for the palm. The pine could not have found foot-hold or sustenance on the granite, nor the palm on the sand-bank, but for these indispensable fore-runners.

The mangrove, like the coco-palm, thrives in salt water, but is unlike it in being able to grow without any preparation, and itself does much to consolidate the mud in which it grows. A mangrove-swamp is not, by all accounts, a delightful place, and is strongly suggestive of malaria and fever, but it must be regarded as only a first step towards arresting and cultivating the mud in many tropical regions.

The mangrove is a low-growing tree with widelyspreading branches, and is wonderfully adapted by its peculiarities to the situations in which it grows. It is found on many tropical coasts, growing between high and low water-mark, and in river estuaries washed by the sea during one part of the day, and left exposed during another. From its branches it sends down long roots which, on reaching the mud, fix themselves frrmly in it, and become independent trees; and the seed, which begins to germinate and grow while still in the fruit and on the bough, also sends out branches and roots sometimes long enough th touch the ground, 


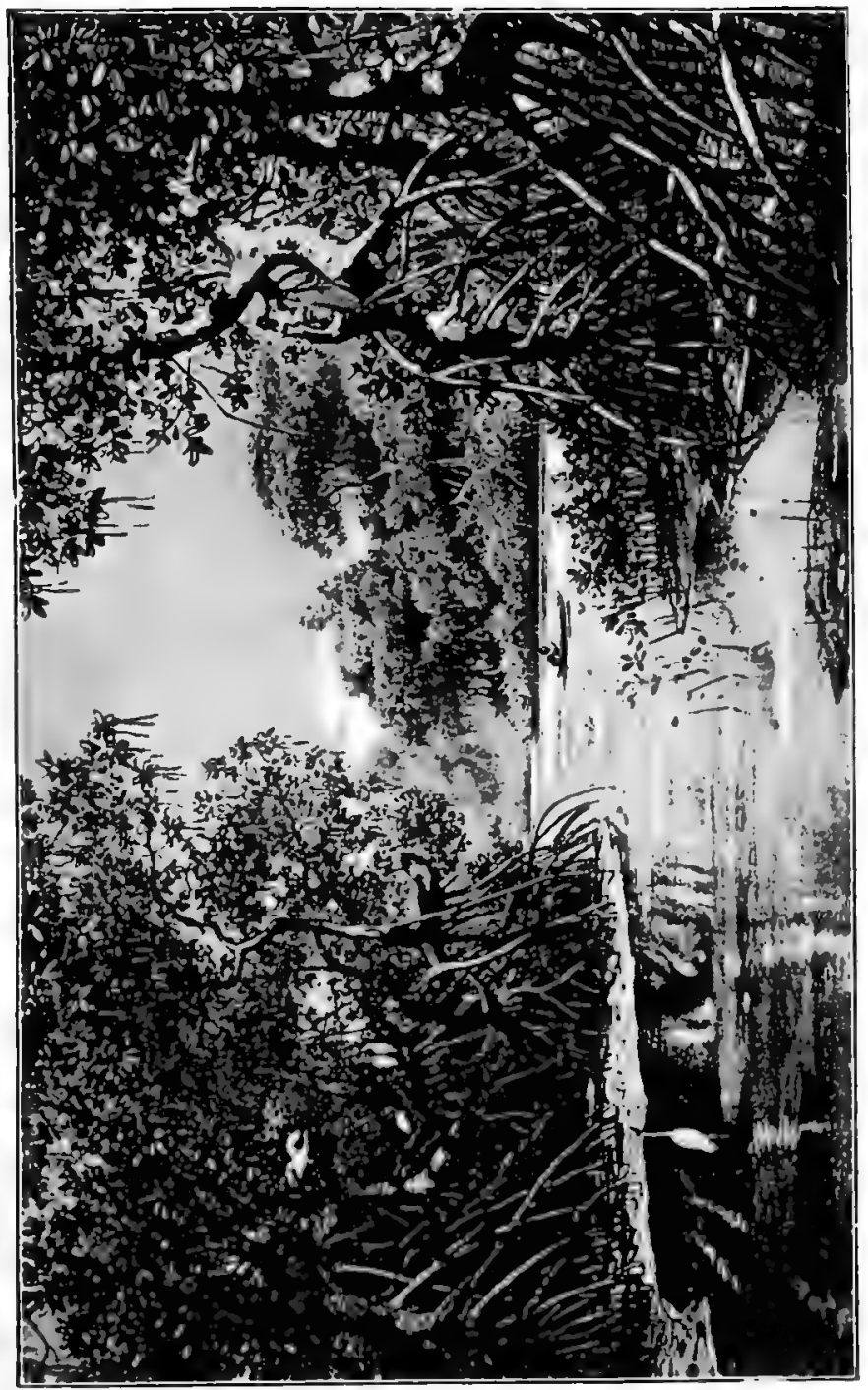



before it falls. The fruit-roots, branch-roots and stems, together form a tough, closely-woven net-work, in which the mud of the river is caught and entangled, and converted into solid, or something like solid, land, very much more quickly than it would be without their help.

In Holland, the people have taken a leaf out of nature's book, and carefully plant the sea-dikes, on which the very existence of their land depends, with the 'sharp rush,' whose multitude of roots mat together near the surface, besides striking deep into the soil.

The horse-tails, too, which thrive there to such an extent that we used to import them under the name of Dutch rushes, have underground stems of extraordinary length, and so much interlaced that they seem exactly intended to bind the loose soil.

Then there is the sea-sedge, an insignificant little grass-like plant, but a few inches high, which does not look capable of much at first sight. But it grows with marvellous rapidity-always an important advantage where loose sand is concerned-and it covers extensive tracts in a very short space of time, sending out, only just below the surface, long, creeping stems, which are firmly pinned down by frequent root-fibres.

The growth of the sea-reed is even more remarkable. It will grow in the very driest soil, and has been planted in the Hebrides to cure sand-drift. Its runners are often as much as twenty feet long, and so tough and strong that they have been used for ropemaking.

Some quite fragile-looking roots are indeed remarkably tough, and capable of resisting an immense strain 
without breaking. The roots of the Lucerne clover are said to be often as strong as those of an ash-tree, though, of course, very much finer, and looking much weaker; and they have at times given unmistakable proof of their strength, not merely by resisting the advance of the ploughshare, but by actually breaking it.

It is this wonderful tenacity which makes roots so useful in binding the soil together, and in keeping the banks of streams and rivers, as well as sea-dikes, from being seriously undermined.

On mountain slopes, too, the roots of trees and brushwood serve to keep in its place the soil which must else slip down by its own weight, even if there were no rain to wash or wind to blow it. And where people have been so short-sighted as to cut down mountain forests, there they have had to lament not merely the ruin, but the actual loss, of the fields in their vicinity, which have been carried bodily away.

In some parts of the French Alps half the cultivated ground has been washed away, owing to the reckless destruction of the pines; and this is not all, for when the forests are gone, not only does the soil follow, but so do the avalanches; or rather they come! plunging down from the heights above and overwhelming everything in their way. The trees, and the trees only, were strong enough to resist them.

It is remarkable what a very slight obstacle is often enough to stop the onward motion of a sand-drift, a few oleanders, by no means very sturdy shrubs, being often found sufficient for the purpose in the Bermudas. A sand-drift cannot, of course, compare with an 
avalanche, but it has also been found possible to stop formidable snow-drifts by means of rose trees!

In the wide plains of South Hungary, where the wind has nothing to break its force, the railway lines are often in winter blocked with snow-drifts, which there seemed to be no means of preventing, until in one part the experiment was tried of planting hedges of Provence roses on each side. The hedges are of the height of a tall man, and the lines were kept clear during some exceptionally heavy falls of snow a few years ago where they were invariably blocked before.

On the south-west coast of France there is an extensive sandy region known as the Landes, which at one time seemed likely to be converted into a veritable Sahara, and was saved from this fate by nothing else but the planting of pines.

It is a sandy region still, and the fine dust arising from it in windy weather gives it the appearance of being overhung with clouds. The sand rattles incessantly against the carriage-windows as the train advances southwards; but in the last century the sand-dunes were always in motion, constantly changing their places, ebbing and flowing like the tide, but creeping gradually further and further inland. When the storm-wind blew from the west it caught up the sand and scattered it over the adjacent country, where it fell like volcanic ashes, doing equal damage and none of the good, for it consists to a large extent of fine white quart $z$, the most hopelessly barren sand there is.

In ancient times this district is said to have been fairly well covered with oak woods, remains of which 
are yet to be seen; why, and when, they were destroyed seems to be unknown, but the results were disastrous and even alarming. At length, however, the happy thought came to an engineer named Brémontier, in I787, that where trees had grown, trees might be induced to grow again, and the attempt was made, not with oaks, for they could not have borne the sand, but with the maritime pine. Over and over again it was tried and failed, owing to the shiftiness of the sand; but at length, by dint of immense perseverance, the seed was induced to take root, and then the worst of the battle was over.

The pine-roots spread little by little, entangling the sand and putting a stop to further rovings; one dune after another was brought to a standstill, and that which threatened to become a desert has gradually been converted into profitable pine-woods, with intermediate stretches of vigorous heather and furze ten feet high, and here and there a thick growth of hawthorn and holly.

We may conclude this chapter by mentioning the curious origin ascribed to certain patches of grass which occur frequently all over the bison region of North America. These patches are said to be evidently due to the bison's habit of wallowing in the dust, and were, in fact, the wallowing places of the herd. The repeated wallowing of a number of animals created shallow hollows or depressions which the rain converted into pools, where the water lingered and into which it drained from the surrounding soil. Even when the water had drained away the hollows would continue damp for some time, and grass-seeds falling upon them would readily spring up. The grass-plants would 
speedily weave a network of roots over the whole, forming in time a thick mat by which the soil would be effectually held together and consolidated, and the bison who wanted a dust bath in future would have to choose a fresh wallowing place for himself and his companions. But the soil would have been won for vegetation, and, once covered with green things, it would not easily be given up again. 


\section{CHAPTER VI.}

FIELD - LABOURERS

THE field-labourers, whose work we are going first to look at, are somewhat rough in their ways, it must be confessed, and not such as the farmer generally cares to see at work upon his land. For when he has taken possession of the beds of soft earth ready prepared for him, his ploughs and harrows come in very usefully, and he is of opinion that he can manage the tillage of his fields himself.

Nature, however, has no steel ploughs, and her fields must be tilled by other means, for they need it as well as the farmer's. And her labourers work in all parts of the farm, giving man a vast amount of help, for which he is often not as grateful as he might be,for he and they do not at present understand one another; and though he may tame a lion he cannot control a worm.

But though they may often be troublesome where man has taken possession, it is to the long-continued services of some of these natural labourers that he owes much of the fruitfulness of some of his richest, lands.

The wonderful fertility of the lands in Manitoba 
for instance, is due, not only to the fineness of the soil, but to the long ages of undisturbed animal and vegetable life by which it has been deepened and enriched.

Every now and again, perhaps, there has been a prairie fire, laying waste wide tracts of country, but leaving a large supply of most valuable ashes behind; and of the value of ashes as a manure, the farmers of Flanders have so high an opinion that they say, 'He who spends nothing on ashes is sure in the end to pay double.' Season by season, too, leaves have fallen, and annuals have withered and decayed, adding their remains to those of countless former generations.

No soil is readly fertile, whatever the mineral matter composing it, unless it also contain some amount of organic matter-matter derived from organized, living things, whether animal or vegetable. Organic matter alone is not enough to make a fertile soil ; but with less than one-half per cent. of organic matter, no soil can be cultivated to much purpose. Even with this quantity it will not grow corn of any kind successfully, but it will grow wild crops with less; and these in time add what is required, if they are let alone for many generations. The Black earth of Russia, which is jet black when wet and brown when dry, owes its colour and much of its fertility to the finely divided and well-mixed vegetable matter which it contains, the remains of countless generations of wild plants, which held undisturbed possession there for ages, but have now made way for their betters.

All soils contain some amount of organic matter, 
animal or vegetable, but chiefly vegetable; and this is true even of such as seem to consist only of sand, clay, or chalk. For wherever it is possible for a plant to grow at all, thither something suited to the situation is sure to find its way. The wild crop may be a very poor one, perhaps only some coarse, wiry kind of grass-for there is hardly any soil so poor but that grass of some kind will grow in it-and when this has improved the soil a little, other better sorts may follow.

The Black earth is of a very dark colour even when dry; but it is not always so easy as in this case to judge of a soil by its appearance. Sometimes the organic matter, being only imperfectly decayed, may be visible enough; sometimes it may be reduced to a fine brown powder; in some cases it may have more or less entirely lost its colour; and then, again, it may be so thoroughly decayed- as to be even soluble in water.

Whether visible or not, however, there it surely is in every soil, in larger or smaller quantities.

But it is the effect of animal life that we are now to look at. Animals, large and small, benefit the land by manuring it; but this is so obvious a benefit that wo need not dwell upon it further than to remark that coprolites-the fossilized droppings and bones of animals of former ages-and guano, the droppings of birds, are among the most valuable manures which the farmer can use, and where they are not to be had upon the spot he finds it worth his while to bring them from a distance. When, therefore, we consider the abundant animal life which for ages occupied many of the lands now brought under the plough, we can understand one 
cause of their fertility-they have been regularly manured for ages.

But besides manuring the land during their lives, the animals must have left their bones to enrich it also, whenever they escaped being devoured. Small dead bodies must have been covered up by leaves, or buried, as we shall see, either by the castings thrown up by worms or by the burying beetles, whose office it especially is to act the part of sexton to the smaller wild animals.

Burrowing animals have also been especially useful in more ways than one. In the first place, they have added to the organic matter of the soil, and, in the second, to the mineral matter also; and besides this they have done much to drain the soil, and expose it to the influences of the sun and air.

The organic matter which they have added, besides their own droppings, consists of the materials which they use to line their nests, principally leaves and grass, and also the remnants of their food, nuts, grain, acorns, and sometimes the whole of their winter stores.

They have added also to the mineral matter of the soil by helping on the decay of the underlying rocks. These are seldom at any great depth beneath, for the loose materials with which they are covered are but as a film of dust compared with the thickness of the solid mass. The soil at its very thickest is measured only by feet, while the solid crust of the earth is measured, at least, by hundreds of miles; and in most cases the soil is actually only a few, often a very few, feet thick.

Burrowing animals often carry their tunnels down 
several feet, and in this way make it easier for the rain and the air to reach the rock below; and wherever these penetrate, there, as has been already shown, decay must surely follow, slowly or rapidly, according to the nature of the rock. In this way, therefore, burrowing animals, whether rabbits, ground squirrels, or even worms, have helped to deepen the soil; and by the lives and labours of these and similar animals, long continued, some of the most fertile lands have been prepared.

We will now look at their work more in detail. All over the Pampas of South America there are frequent groups of holes excavated by the bizcacha, a curious, rabbit-headed animal, as large as a badger; and in South America also, but chiefly in the mountain valleys, dwells the bright-eyed, soft-furred little chinchilla, not much larger than a squirrel, whose burrows are found together in such large numbers as to cause almost as much inconvenience as those of the bizcacha.

In the western regions of North America, from. Mexico to the Arctic Ocean, as well as in the northern parts of the Old World, there are a large number of small animals called by the general name of 'groundsquirrels,' and resembling tree-squirrels in many respects, though some of their habits are very different. Like the tree-squirrels, they lay up stores of food, but, unlike them, they burrow in the ground, and live together in large villages instead of in pairs.

One of these, the Chipmunk or Hackee, abounds in parts of North America, where it makes very extensive excavations, considering its size, which is less than that 
of a tree-squirrel. It has a large nest lined with leaves and grass; and the storehouses of one burrow have been found to yield a grand supply of food-a quart of hazel-nuts, nearly a peck of acorns, two quarts of buckwheat, and smaller quantities of other vegetable food.

The Prairie-dog, of the same family, is rather larger, and something between a squirrel and a marmot in appearance. Its 'villages,' 'towns,' or warrens cover many square miles, and in some parts are so extremely numerous as to have undermined extensive tracts of pasture-land, much to the inconvenience and danger of horses, not to mention their riders.

The dog-towns, so-called, are ruled by a 'big-dog,' who sits on a mound in front of his burrow, apparently directing the affairs of the community.

The Gopher, or Canada pouched-rat, too, is to be found in the prairie, where it dwells not merely in thousands, but in hundreds of thousands, and has so completely taken, perhaps we should rather say kept, possession, that in some parts other quadrupeds are almost excluded. The Gophers extend over hundreds of thousands of square miles, and have honey-combed millions of acres. One may indeed ride for days and even weeks through some districts, finding them everywhere as plentiful as if the whole district were one vast warren. If ever the lands should be settled, the first husbandmen will have a hard fight for possession with the present owners, whose diligence in burrowing is wonderful, for they work both night and day, though they do not go nearly as deep as the 'dogs.'

The burrows will just admit a man's arm at the 
mouth, growing narrower farther down, but they make up in numbers for what they lack in size. Each Gopher lives alone in a burrow of its own; there are separate burrows to hold the winter stores, and large numbers seem to be made either for temporary refuges, or from a pure love of digging which can never be satisfied, for the deserted burrows are many more than can be accounted for by the size of the colonies.

Other burrowers, better known in the Old World, are the marmots, which make very large and rather complicated burrows, and have quite riddled the rocks in Turkestan, in some parts of which they abound; and others again of the same great family of rodents, or 'gnawers,' the Gerboas, have honey-combed the sides of mountains in South Africa, and possess such strong teeth that in the north they even gnaw through the thin layer of stone beneath the sand, and thus do some of the very first work of the pioneer labourers.

Every country, indeed, seems to have its special burrower or burrowers, and everywhere their work has similar results, often troublesome enough, where man has established himself, but doing a useful and important part of the work of the farm, of which man reaps the benefit in after years.

In England the field burrower with which we are most familiar, unpleasantly familiar, too, is the common mole. No matter where he lives, the mole's labours are not anywhere looked at with a friendly eye by farmer or gardener; and so fierce is the war waged against him that it is matter for wonder how he has managed to escape extermination. Mole-catchers boast of having slain many tens of thousands, one declaring that he had trapped twelve hundred in six months. Yet still 
the mole lives on; lives and labours, as some say, in the service of ungrateful man.

The sins alleged against him are : that he drains the soil so thoroughly by his network of underground galleries as to render it dry and barren; that he damages the crops by uprooting them, and by exposing, destroying, or eating their roots ; and, finally, that he uses such a large quantity of spring corn, as much as a couple of hundred blades, to make his bed, that where he abounds one-eighth of the crop is lost.

These are serious accusations; but the mole is not without friends, enthusiastic friends even, though probably not farmers or gardeners, and these declare that the damage done is slight compared with the service rendered. The soil is greatly benefited, say they, by being upturned and lightened; and they claim that the mole takes high rank among nature's field-labourers, and should be honoured accordingly, not only for his work as ploughman, but also for his extraordinarily large and voracious appetite for smaller animals of all sorts, which do far more injury to the crops than himself.

It is, however, too much to expect that any gardener of tidy mind should look favourably upon an animal which throws up earthworks in the middle of his neat paths and borders. The mole has occasionally done even worse damage than this by burrowing through dams and dikes, thereby causing inundations, which, though they have their use in fertilizing the soil, are not generally desirable where man has taken over nature's fields, and would prefer to cultivate them in his own way. 
Putting aside for the present the mole's services as a devourer of injurious insects, which are certainly great, we may perhaps admit that we do not now need him as ploughman, as we have our own ways of doing his work. But it would be very rash to say that we could dispense with him altogether; and even if we could nore, this need not make us overlook the share which he has had in the past, and in unoccupied lands still has, in preparing the soil for our use.

Wherever a mole lives the organic matter in the soil must be continually receiving increase, for it lives almost entirely on animal food-such as worms, grubs, insects, as well as mice, dead birds, lizards, frogs; and as it is extraordinarily voracious, large numbers of these must be consumed, their remains, digested or not, being left in the earth: Large quantities of vegetable matter are also carried into its nest by every mole every year, and there they are, of course, left to decay. When, therefore, one thinks of the thousands of moles still existing, and the many more thousands and millions of past countless generations, every one of which lives, or lived, the same sort of life, always burrowing, always feeding, and always making nests year by year, it is evident that their effect upon the soil-in places where they are, or have been, plentiful-can certainly not be small.

Some might like to be rid of them now, though probably, if they had their will, they would find cause to regret it; but in unoccupied land the mole has certainly done nuch service.

And now we turn to another very different set of workers, most unlikely ones we should say at first sight, who are helping to improve and prepare some of 
the limy mud-flats of the East Indian Archipelago. At present, we believe, their work has been watched only on the Keeling or Coroz Islands; but what crabs are doing now crabs may have done, and have most probably done, in the past, so that some part at least of the present fertility of other mud-flats, perhaps of coral islands, may be owing to them.

But what, it may be asked, can crabs do? They burrow, for one thing; and they make their homes so close together that as many as a hundred and twenty of these narrow, corkscrew holes have been counted in a space only two feet square, so that the ground is very thoroughly perforated indeed. And they not only burrow, but are incessantly busy carrying down twigs, bits of seaweed, scraps of coco-nut shell, seeds, and so forth, with the object of making themselves comfortable, it is to be supposed, and yet it almost seems as if they laboured, some of them, in this industrious way simply and solely for the sake of improving the soil.

One of these crabs works so near the water that its burrows are covered at high tide; another works a little further in, and a third further still, where the mud is dry; but what is curious about this last is that as soon as the white, chalky mud has been turned into dark vegetable soil, which it is by the decay of the various things dragged into it-at once the crab goes off to another fresh spot, and begins all its work over again. Perhaps it does not like decayed vegetable matter; but the result is that it is always at work, and must get through a good deal of digging in the course of its life.

Further inland still, the soil is dry and turned up to the sun and rain by the 'great coco-nut crab,' one of 
the largest that live on the shore, whose deep tunnels are larger than rabbit-burrows, and are lined with coco-nut fibre.

Beetles, again, are most useful workers, almost all the world over, and on some of the wild hill slopes of Ireland all the patches of good grass are said to be their work. Cows are kept on these wastes, and are attended by numbers of large beetles. Three or four of these together set to work at a patch of cow-dung, burrowing into the soil beneath, and bringing up little heaps of clay until they have covered it three or four inches deep. Their object, no doubt, is to make a suitable place in which to lay their eggs, for the grubs when hatched live upon this food; but they at the same time provide a suitable bed for grass-seeds, which is quickly taken possession of.

The Dumble Dor beetle, or Flying Watchman, the slow, hump-backed, bluish-black creature, which is often found lying on its back, goes to work in a different way, and in spite of its slow movements gets through what is really an amazing amount of work for its size. We all know it probably, though we may not all have watched its operations. It, too, is an attendant upon cattle, and works so expeditiously and in such large numbers as to clean a meadow tenanted by cows in three or four days. Instead of bringing up earth to cover the droppings, it removes them altogether, pellet by pellet. It digs its way down between the grassroots, carrying with it as much as it can to a hole a foot deep, where it lays one egg; after which it crawls up again for more, over and over again, making many journeys. As many as forty or fifty burrows have been counted in one square foot. 
In tropical countries, where animal life is abundant, dung-beetles of many species are especially plentiful. The great Scarabæus of Egypt, which is common throughout Africa, as well as in the south of Europe, may be looked upon as the head of the family, some of the members of which are of very large size. Some of the family, like the Carrion-eaters, bury the dead bodies of small animals, which, though small, are many times larger than themselves.

Burying beetles, of one species or other, are everywhere plentiful, so plentiful indeed that we very seldom meet with the dead bodies of bird, mouse, or mole, or any other animal, in our walks in field or wood. All have been cleared away and buried several inches, sometimes nearly a foot, underground, where they benefit the soil, besides providing food for the beetle's family - this latter being of course the only object which the beetle has in view. They work sometimes singly, sometimes in company, scraping the earth away from beneath the carcase with their forelegs, and then carefully covering it up; after which they burrow down and lay their eggs. One beetle alone has been known to bury a mole forty times its own weight; while four together have been seen burying a crow; and if we consider for a moment what a task it would be for a man, alone and unaided, to bury an animal weighing forty times as much as himself-say four hundred stone-we may gain some idea of the vast amount of work performed by these insects. Four beetles which were kept and watched for fifty days, buried in that time four frogs, three small birds, two fish, one mole, two grasshoppers, the entrails of a fish and two pieces of ox liver. But even rabbits are not too large for 
them; and one foreign species will bury a snake in a few hours.

Burying beetles of the many carrion-feeding species abound especially in temperate climates, for there it is that there is most work for them to do, since there dead bodies decay but slowly. In those parts of the tropics where great heat is combined with extreme dryness-as, for instance, on the Pampas of South America or in the African deserts-a body is dried up so quickly that it can hardly be said to decay at all. A dead horse can even be used as fuel, and there the carrion-feeders are comparatively few. They are little needed as scavengers, and, unless covered up immediately, the dead body of any small animal such as they could bury would supply little food for their grubs. 


\section{VII.}

\section{FIELD-LABOURERS- continued.}

'THE plough is one of the most ancient and most valuable of man's inventions; but long before he existed the land was, in fact, regularly ploughed, and still continues to be thus ploughed, by earthworms.'

Earthworms are continually busy about this work over pretty nearly the whole world, 'reversing the earth's crust, turning it over and over, from year to year,' as the ploughman does, 'only much more slowly, and much more thoroughly, spadeful by spadeful, foot by foot, and even grain by grain.' And the earthworm's work has another great advantage over that of the ploughman. It is not only more thorough, but it can be, and is, carried on even while the crops are growing, and that without any material injury to them.

We have learnt much about the earthworm of late years, thanks to Mr. Darwin; but long before 'Vegetable Mould and Earthworms' was written-more than a hundred years ago, in fact-Gilbert White, the naturalist of Selborne, had a very good idea of the worm's importance as one of nature's field labourers. 'A good monography of worms,' he wrote, 'would 
afford much entertainment and information at the same time, and would open a large and new field in natural history.' 'Vegetation would proceed but lamely without it, so great are its services in boring, perforating, and loosening the soil, and rendering it pervious to rains and the fibres of plants, by drawing straws and stalks of leaves and twigs into it, and, most of all, by throwing up such infinite numbers of lumps of earth, which is a fine manure for grain and grass.'

Gardeners and farmers hated the worm in his day, as the former at least do still; but he remarks that they would find 'the earth without worms would soon become cold, hard-bound, and void of fermentation, and consequently sterile.'

The earthworm is an animal possessed apparently of more than the traditional nine lives, and endowed with a wonderful power of adapting itself to the most diverse and most adverse circumstances. Bodilyinjury affects it but little, so far as life is concerned. One worm is said to have been beheaded eight times in succession, and to have perseveringly grown a new head each time; another was cut into fourteen pieces, thirteen of which became perfect worms, while only one died.

Earthworms closely similar in appearance to those which we know in England are found in soils of the most various kinds and in almost all parts of the world. The English species is extremely plentiful on commons and chalk downs, where the soil is poor and the grass short and thin, and it is almost equally abundant in some of the London parks, where the soil is rich. But their numbers may vary in different parts even of the same field, showing that they have their pre- 
ferences, though it may not always be easy to discern the reason for them. Moisture, however, they cannot do without, and hence, while they avoid dry sand and heaths, they frequent paved yards near houses in large numbers.

On the mountains of North Wales and on the Alps they are rare, owing perhaps to the lack of sufficient depth in which to make their winter burrows; but they are found in Scotland on hills I,500 feet above the sea ; near Turin, at a height of 2,000 or 3,000 feet; on the Nilgiri Mountains of South India, and on the Himalayas. They have, indeed, an enormous range, occurring in the most isolated islands, abounding in Iceland, and found in the West Indies, St. Helena, Madagascar, New Caledonia, Tahiti, Kerguelen's Land, and the Falkland Islands, though how they reached these is at present a mystery, since sea-water is absolutely fatal to them. In the United States they are plentiful; in Venezuela, common in gardens and fields; in South Brazil the soil, to the depth of a quarter of a yard or more, looks in most parts of the forest and pasture land as if it had repeatedly passed through their bodies. Even in the dry soil of New South Wales their castings abound, and in the hot, moist jungles of Bengal they occur almost everywhere.

Strange to say, they seem to be either absent or uncommon in the Canadian prairies-that is, they never seem to have come in the way of the surveyors; but, after all, this does not prove much.

Almost the whole surface of every moderately damp country is covered with a layer of fine, dark, vegetable mould; it is only a few inches thick at most, from four 
or five to perhaps twelve inches, but no matter what the nature of the soil beneath, there it is. One may see it in any railway cutting, or on the top of any bank, be it chalk or be it sand; and this black earth, or humus, is, to a very large extent, the work of worms.

In a very loose soil worms can move easily, but, generally speaking, as their bodies are soft, and cannot pierce through anything at all hard or close, and, as they have nothing but their mouths to work with, they are obliged to eat their way through the ground. No doubt they are fed, to some extent, by the animal or vegetable matter contained in the soil, but their primary object in swallowing it does not seem to be food; to swallow it is the only way they have of getting rid of it, and their real object is to make a tube or burrow in which to live.

Where other food is scarce, or absent, they must, of course, live on what they can get from the soil, and, in purely mineral soils, they are rare accordingly, as they could not find sufficient nourishment in it in case of necessity.

The effect produced upon the soil by its passage through their bodies is very marked: it is not only rendered extremely fine, but its colour is gradually altered, becoming darker and darker, until, after repeated swallowing, it is turned almost black. The layer of dark mould which covers our fields is dark just because it is composed of the castings of worms, castings which have passed through their bodies over and over again, times innumerable.

The worm has no teeth, and its mouth is a mere opening, but it has the power of flattening its head and extending it on each side of this opening so as to form 
two lips, with which it is able to grasp leaves and other things firmly enough to drag them into its burrow. Sometimes, however, it seems to vary its manner of proceeding, and, instead of grasping the object it wishes to move, it presses its mouth upon it until it adheres firmly by mere suction.

Worms are omnivorous: they will eat anything eatable, and will feed daintily upon half-decayed flowers and almost any kind of vegetable matter, or coarsely upon their own dead comrades, or meat when put in their way. But their chief food consists of halfdecayed leaves, enormous quantities of which are pulled into their burrows, torn into small shreds, and then swallowed and digested; and it is this vegetable matter which changes the colour of the earth which the worms swallow with it, and converts it into 'mould' - vegetable mould.

Two worms kept in a large pot of sand, well moistened, of course, but consisting only of mineral matter, converted the top layer into vegetable mould four inches deep, simply by the help of the leaves strewed on the surface.

In woods the fallen leaves are being constantly covered with worm castings, and thus converted into rich soil; and in Sumatra the ground in the forests is almost as rough as a field which has been literally ploughed, so thickly is it covered with large worm heaps eight inches high, often thrown up in a single night. There may be as many as ten or twelve of these in a square yard, and the creatures seem to be incessantly at work bringing up soil and burying leaves, twigs, etc.

As to the actual amount of soil swallowed by worms, 
it varies, of course, according to their size, in which they differ very greatly. There is a worm in Ceylon about two feet long; in the Nilgiri Hills, already mentioned, they are twelve or fifteen inches long and as thick as a man's little finger; while on the Amazon there are some as much as two feet and a half long and thick in proportion, and able therefore to do much work.

Seeing only the little dark heaps of soil thrown up by worms on grass-plots and gravel-paths, heaps which are soon washed down again by rain, one has some difficulty in realizing the vast amount brought up in the course of a year. But Mr. Darwin reckoned that near Nice this amounts to from about fourteen to eighteen tons to the acre; this is supposing them to be as numerous and active over the whole of a field as they were in the one square yard chosen for observation; but it is also supposing them to work for only six months of the year, which he considered a low estimate. The largest amount was brought up on very poor pasture, where leaves were probably scarce, and the worms had to swallow much earth in order to obtain sufficient food.

On the whole it seems probable that they bring up more than ten tons of soil to the acre in many parts of England year by year, and that the entire mass of mould-the dark surface-soil of every field-passes through their bodies in the course of a few years, and is by these means sifted and rendered extremely fine, besides being thoroughly impregnated with vegetable and animal matter. Moreover, bones, twigs, leaves, shells, are constantly being covered with castings, and these further help to enrich the soil by their decay; 
whereas, left upon the surface, they would benefit it but little. Large earthworms sometimes bring up soil from a great depth: in sandy soils, for instance, their tubes go down from three or four to six feet, and are then continued horizontally; and the whole contents of these tubes must, of course, be brought to the surface.

Estimates differ so much that it seems hopeless at present to try and calculate their numbers. But this one thing we know, there are many thousands in every acre of moderately damp land, and, grain by grain, the whole surface is literally 'loughed and saturated with fertilizing juices.

So far from being over-rated, as some have thought, the earthworm is now proved to be an even more valuable field-labourer than was supposed, and it is said that, in estimating the value of land for farming purposes, no satisfactory conclusion can be arrived at unless the number of worm-holes be taken into the account.

Besides grinding up the soil in the process of digestion to a state of extreme fineness, besides adding to it vegetable matter and darkening its colour, worms are most useful in another way: they prepare channels through which the roots of plants are able to spread with ease. Plants evidently prefer, when they can, to take advantage of ready-made passages, and worm burrows which have been in existence some little time are usually found lined to the very end with fine roots and rootlets, the latter covered with fine hairs, through all of which the plant absorbs food.

Roots of red clover have been found running down six feet, or more, into the ground by means of these 
holes, and the plant of course gains by this. The longer the root, the larger the surface with which it is brought in contact, and the larger the supply of food which it can extract; and it obtains this food more quickly where it can run through a tube than where it has to force its way through close soil, and consequently the plant grows more rapidly.

Much of this will be more readily understood when we come to speak of how plants feed and grow; but we may mention here that plants which are able to send down roots to any considerable depth have the advantage of reaching soil which is quite fresh and unexhausted : they have also plenty of room in which to develop their roots, and, more important still, their roots are kept warm and well supplied with moisture at all times, even when the surface of the ground is frozen hard. Dig through the frozen surface, and you will always find moist earth beneath; so also even in drought, there will be more moisture below than on the surface; and this moisture plants are enabled to reach by means of the worm-tubes, instead of spreading their roots only, or chiefly, through the surfacesoil as they might otherwise do.

However, as we have observed already, man may tame a lion, but he cannot control a single wormcannot make his wishes understood or respected by one of these insignificant creeping things ; and so, as the worm's proceedings are at times exceedingly irregular, he blames the worm, and sometimes goes so far as to deny that it does any good at all.

Their way of top-dressing lawns and paths does not improve the appearance of either, we must admit ; topdressing may be all very well in a meadow, or in the 
rice-fields of Bengal, which are very soon studded with worm-heaps after they have been flooded, but in a garden we are inclined to think it out of place. And it is true that, in the Botanic Gardens of Calcutta, the lawns are covered in a single night or two, if they are left unrolled, with tower-like castings, which weigh some ounce and a quarter each, and are anything but sightly.

Sometimes, too, the earthworm may disturb seedlings by burrowing, but it does not eat them. Neither does it touch living roots, as it has been suspected of doing, at least when these are growing in the open ground; though what it may do when confined in a pot, and pressed by hunger, is perhaps another matter.

In spite of some drawbacks, however, it would be not merely hard but absolutely impossible for man to contrive any substitute for these natural ploughmen if he could succeed in banishing them.

But people are never all satisfied; and among the malcontents are some who find fault with the worm, not for doing too much, but for doing too little! It works, say they, only for a few months of the year, and therefore does not deserve so much credit and gratitude after all.

The poor worm cannot work in dry soil. Indeed, moisture seems to be the one thing essential to it ; for though it can stand much bodily ill-usage, it is actually killed by exposure to the dry air of a room for even a single night. In hot countries, such as Bengal, therefore, it can only work during the cool season, about two months, after the rains; and even in the moist climate of England it cannot work near the surface during the dry weather of summer, any more than 
in hard frost. Gilbert White remarked that worms worked most in spring; but he added that they were by no means torpid during the dead months, and were in fact out, even in winter, on every mild night.

There is, however, another and much smaller animal, which, as some people think, has done much work hitherto attributed to the overpraised worm. Ants have not generally had the reputation of being useful to the agriculturist, however clever some of them may be as agriculturists on their own account; but in Ireland, according to at least one observer, they do appear to have been most useful; and if in Ireland, then why not elsewhere?

These Irish hill-building ants love what the worm cannot bear, a dry, sandy, or peaty soil ; and they are busy at work from early spring to late autumn, all through the hot weather, when the worm is comparatively idle. Yet even so, they do not work for more than about five months of the year; whereas the worm works on an average at least six, and in mild, damp winters often much more.

However, whatever their respective merits, the ants work where and when the worms cannot do so, and are most useful where there are crags, or large stones, with patches of sandy peat; for the hill-building ants always choose rock to build upon, and gradually cover the surface with soil. These patches are at once taken possession of by grass and other seeds, and so the soil is kept in place. During the winter there may be a little loss by wind and rain, but the greater part is held together by the roots, and a patch of permanent vegetation is formed where previously there was only bare stone. 
A single colony of ants seldom covers less than two square feet, and sometimes more than three; and as they generally choose a fresh place every year, they really do a great deal towards clothing bare places.

The ants which work on the sandy moors seem to keep to the same spot year after year, but their hillocks are much taller, sometimes as much as four feet high and a yard across at the base, all composed of soil brought up from below mixed with refuse vegetable matter, and in this way much of the unprofitable peat is converted into good soil.

In some parts of Ireland the work done by ants is, if not larger, at least much more noticeable than that done by worms, and it is believed that the space covered by the work of the two is about equal.

But in the tropics worms are, of course, quite powerless during the greater part of the year, the soil being either baked to a brick or dried to dust. In the burning deserts of Nubia a worm was never seen or even heard of, and even in a tropical forest during nine months of the year the soil is so hard as to be quite unmanageable by its jaws.

In the sub-tropical parts of South America and India, worms swarm out in endless numbers when the rain comes, but in the tropics proper, except in the moister regions, they are on the whole few. Not one was seen by Professor Drummond in Central Africa, even during rain, and he suggests that their place is taken in these parts by the termite, commonly, though erroneously, called the white ant.

The white ant lives underground, and being quite defenceless, it has such a dread of exposure that when 
obliged to come out for food it brings some of the earth with it, and builds a tunnel within which it always remains.

The food of the termite is dead wood, and, not content with what it finds on the ground, it climbs the trees in search of it, toilsomely carrying earth for its tunnels wherever it goes. There may be perhaps a few feet of dead wood at the end of a long branch some thirty feet from the ground, and the whole distance must be covered in if the termite is to reach it. But as it does not know exactly where the food desired is to be found, it more often than not covers the whole tree with tunnels and galleries made on speculation.

The extent to which this tunnelling is carried, and the amount of earth brought up, are something incredible. In some districts of tropical Africa there are millions of trees covered with tubes, every one of which must be plastered over with many pounds of soil. The tunnels generally are about the size of a small gas-pipe, some occasionally larger, and here and there are large chambers covering nearly the whole trunk for some feet. Every branch, every twig has a tunnel, and as for the dead wood which falls to the ground, none is ever to be seen, as it is at once encased in soil. At first sight the traveller may think he has found a faggot, but on closer inspection it proves to be nothing but a cast in mud, a very perfect cast, with all, even the minutest, knots reproduced.

But of trunks, branches, boughs, or even twigs lying about on the ground, there is nothing to be seen. All are eaten up.

The outside texture of the termite galleries is like that of coarse sand-paper; but being intended for 
temporary purposes, only they crumble into dust after a little exposure. But the dust, brought up from the sub-soil in the first instance and now returned to earth again or scattered abroad by the wind, has been altered in character; it has been powdered for one thing, and it has been to some extent mixed with animal juices for another, since the only 'mortar' at the termite's command is its own saliva, by means of which it makes the grains adhere together. So far, then, the soil which the termite has brought up from below is richer than before; but the chief point gained seems to be that the soil is being constantly turned over and over.

Some districts are more especially favourable to the termite than others, and in one of these there are miles of trees all covered with. its earthworks. 'The soil of the tropics is therefore in a state of perpetual motion. Instead of the upper crust being converted into a paste by the autumn rain and then baked to adamant, the under soil being hermetically sealed up from light and air, there is a slow constant transference, grain by grain."

But the tunnels do not represent nearly all the termite's work, though they are much. Besides these, there are the nests, mounds of earth of huge size, which are a common feature of the African landscape, and can be seen for miles. In India they are seldom more than a couple of feet or so in height, but in Central Africa they are from ten to seventeen feet high and contain many tons of earth, while the excavations beneath are many feet and even yards deep.

The mounds are not solid, but composed of many tunnels, chambers, and galleries, yet they are so strong that they will bear the weight of a man on horseback. 
The exterior is, indeed, brick-like or stone-like in its hardness, but with all its strength it must give way at last beneath the fury of the tropical rains, which continue off and on for two or three months at a time, and thus the soil is returned to the earth enriched by its admixture with animal matter.

Ants, true ants, as well as white ants, abound everywhere within the tropics, but they also do a large amount of work outside, though their numbers gradually diminish as we go further and further north and south.

There are 'ant-cities' in Pennsylvania, each of which contains more than 1,600 nests of various size, the largest being fifty-eight feet round the base and fortytwo inches high, with galleries some sixty feet long leading to the feeding grounds.

The muscular power of these ants is truly wonderful. The loads they carry are twenty-five times their own weight, and they carry them what, for their size, is an enormous distance. It is as if a man of ordinary size were to carry a weight of 4,000 pounds from the bottom of a coalpit to the top of the Great Pyramid. And they have not merely to carry these loads, but first to prepare them.

The ant begins work by scratching with her forelegs like a dog; later on she bites, cuts, or twists off pellets of earth, during which process she often works like a collier on her back, and then she compresses the particles into a ball and carries them out. The only implements she has for her work are her mandibles, or first pair of jaws, which are placed outside her mouth, each jaw being furnished, with seven teeth. These powerful jaws serve as pick, shovel, crowbar, 
saw, axe, and cart, all in one, and as the little creature grows old her teeth are gradually worn down by the hard work they have done, just as a workman's tools are worn.

The number of these ants is simply enormous; and, besides enriching the ground by the quantity of leaves with which they fill their storehouses, they also perforate it to a considerable depth. Some of their subterranean galleries have been traced down fifteen feet, and found to be still descending. Whatever the depth may be, from it they bring up the soil with which they build their mounds; and in Brazil there are very large deposits of earth which have been raised to the surface entirely by the ants.

Thus not only is fresh soil continually exposed to the action of air and rain, but ways are opened by which the same air and rain may penetrate to the underlying rocks and carry on the decaying process, as described in an earlier chapter. Nor must it be forgotten that wherever there is decaying vegetable matter, there carbon-dioxide and other gases are formed, which are absorbed by the rain in its passage through the earth, and increase in a very high degree its power of acting upon the rocks beneath.

The ants' store-rooms, the worms' burrows with their quantity of decaying leaves, the ground-squirrel's hoards, and the beds made for themselves or their young by mole, marmot, and the like, all increase the organic matter and the supply of carbon-dioxide in the soil; while their various burrows, large and small, make an easier passage for the rain.

We cannot attempt to give more than a sketch, and 
The exterior is, indeed, brick-like or stone-like in its hardness, but with all its strength it must give way at last beneath the fury of the tropical rains, which continue off and on for two or three months at a time, and thus the soil is returned to the earth enriched by its admixture with animal matter.

Ants, true ants, as well as white ants, abound everywhere within the tropics, but they also do a large amount of work outside, though their numbers gradually diminish as we go further and further north and south.

There are 'ant-cities' in Pennsylvania, each of which contains more than $\mathrm{r}, 600$ nests of various size, the largest being fifty-eight feet round the base and fortytwo inches high, with galleries some sixty feet long leading to the feeding grounds.

The muscular power of these ants is truly wonderful. The loads they carry are twenty-five times their own weight, and they carry them what, for their size, is an enormous distance. It is as if a man of ordinary size were to carry a weight of 4,000 pounds from the bottom of a coalpit to the top of the Great Pyramid. And they have not merely to carry these loads, but first to prepare them.

The ant begins work by scratching with her forelegs like a dog; later on she bites, cuts, or twists off pellets of earth, during which process she often works like a collier on her back, and then she compresses the particles into a ball and carries them out. The only implements she has for her work are her mandibles, or first pair of jaws, which are placed outside her mouth, each jaw being furnished, with seven teeth. These powerful jaws serve as pick, shovel, crowbar, 
saw, axe, and cart, all in one, and as the little creature grows old her teeth are gradually worn down by the hard work they have done, just as a workman's tools are worn.

The number of these ants is simply enormous; and, besides enriching the ground by the quantity of leaves with which they fill their storehouses, they also perforate it to a considerable depth. Some of their subterranean galleries have been traced down fifteen feet, and found to be still descending. Whatever the depth may be, from it they bring up the soil with which they build their mounds; and in Brazil there are very large deposits of earth which have been raised to the surface entirely by the ants.

Thus not only is fresh soil continually exposed to the action of air and rain, but ways are opened by which the same air and rain may penetrate to the underlying rocks and carry on the decaying process, as described in an earlier chapter. Nor must it be forgotten that wherever there is decaying vegetable matter, there carbon-dioxide and other gases are formed, which are absorbed by the rain in its passage through the earth, and increase in a very high degree its power of acting upon the rocks beneath.

The ants' store-rooms, the worms' burrows with their quantity of decaying leaves, the ground-squirrel's hoards, and the beds made for themselves or their young by mole, marmot, and the like, all increase the organic matter and the supply of carbon-dioxide in the soil; while their various burrows, large and small, make an easier passage for the rain.

We cannot attempt to give more than a sketch, and 
that a very slight one, of the work done by nature's various field-labourers; but, slight as it is, it would be incomplete without some mention of the very curious animals known as ant-eaters, which are found throughout the tropics.

These creatures have very long, thin, pliable tongues, looking like red earthworms, and as if they were endowed with independent life; and when they can get at them they lick up the ants with marvellous rapidity.

The ants, as we have seen, dwell, many of them, within walls almost as hard and strong as if built of stone or brick, capable, one would think, of defying the attack of almost any animal. But ant-eaters are armed with tremendously powerful claws-so powerful that with them they are able to dig and tear down even these strong citadels; and this done, they sweep up the terrified inhabitants by thousands.

Ant-eaters of the Manis family, long-tailed and shorttailed, which are found in Africa and Asia, are covered with horny plates, sharp-edged and overlapping, the points turned to the tail and raised, so that they have the combined advantages of scale-armour and the hedgehog's bristles.

The Aard-Vark, or Earth-hog, of South Africa, is a very different-looking animal, covered with coarse, bristly hair, and about five feet long with its tailaltogether too large, one would have fancied, to be satisfied with such very small food as ants. Its forelimbs are very powerful, and armed with long, hooflike claws, with which it digs through the hardest mounds and burrows in the hard-baked earth faster than a man can dig with a spade.

The great Ant-eater, or Ant-bear of tropical South 


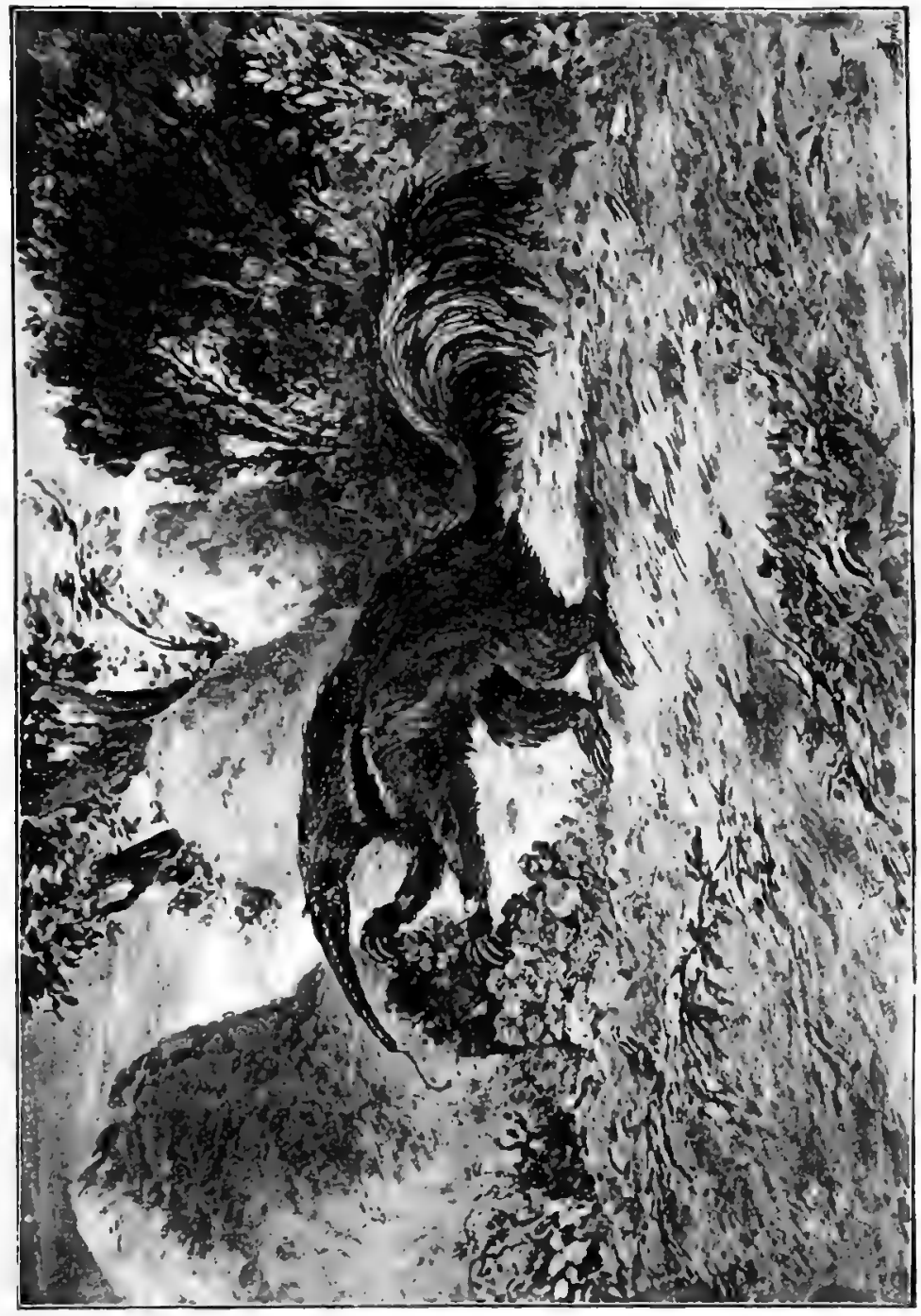



America, is like the Aard-Vark, but larger, and is so bold that it will sit up and fight even a 'tiger,' or more properly jaguar, with the very long curved claws of its fore-feet. Yet, notwithstanding its size and strength, it lives chiefly on ants.

By these and other ant-eaters the hills and mounds of the ants are demolished, and the earth which they have excavated with so much labour is returned to the soil. And it is returned in an altered state, much finer than before, and enriched to some extent at least by what has been added to it, and so is better fitted for the support of plant-life. 


\section{VIII.}

WA T E R

THE soil may have been ground and mixed, perhaps transported long distances, and otherwise prepared by the various labourers already described; but even then no crops, whether wild or cultivated, can thrive in it without moisture. In perfectly dry soil they must starve in the midst of plenty; for they can no more get at the food around them, however abundant it may be, without water, than if it were locked up. To them, indeed, under such circumstances, it is locked up.

Of course, we all know, as a matter of fact, that plants fade and wither, and eventually shrivel and die, if they be kept without water. We may know, too, that three-quarters of the weight of most plants, and a great deal more of many, is made up of nothing but water. But when once they have had a supply of water, why should they need more? Cannot they keep it? and if not, how do they lose it? Why do they need constant watering?

A potato is watery: only one-fourth of its weight is solid matter ; the rest is all water. An artichoke contains still more water, and still less solid matter; a 


\section{Water}

91

turnip is more watery still; and a pumpkin contains only five and a half per cent. of solid matter.

And yet, when we have stored our potatoes and turnips, or our pumpkins, we do not find it necessary to water them. They do not shrivel; they keep their moisture. Why does not a plant do the same?

The only answer to this question is, simply because it can't. It cannot shut the many mouths by which it is constantly losing moisture. We human beings cannot prevent the escape of water through the pores of our skin, or in the breath which we breathe; and the plant is in similar case. It is constantly giving off water, and if the loss is not made up it must needs become dry and shrivel.

Almost every part of a plant which is exposed to the air, and not covered by a layer of cork or of thickened skin, is constantly losing moisture in ordinary air ; and unless the roots can suck up enough to make the loss good, it droops, flags, withers, and dies.

The potato and the pumpkin are protected - the one by cork, the other by thick skin-and they are therefore able to retain their moisture for a considerable time. In a similar way, the stems of most woody plants and trees are protected by layers of cork, and often of fibrous bark as well, which almost, though not altogether, prevent the escape of water. It is the young, green stems, the growing parts, and the leaves by which it is chiefly allowed to go off into the air; and these are just the parts which especially need the mineral food, the food derived from the soil, which the roots are constantly preparing.

How are the roots to convey this food to the growing parts of the plant? Of course, they cannot do so; 
they can only make it ready, and then it must be pumped up to where it is wanted. Accordingly, as the water is drawn off, so to say, above, the sap from below -that is, water containing food from the soil-mises to supply its place.

A constant current, therefore, rises from the roots upwards; but a great deal of this would be lost during its passage before it reached the young shoots but for the fact, already mentioned, that the trunks or stems through which it passes are protected against the air, and moisture can escape but very slowly through bark or cork, though it does still escape to some small extent.

When the sap reaches the green parts of the plant it passes off into the air as invisible vapour; or, rather, the water of the sap passes off in this way, and the food from the soil, the mineral matter, is left behind. But even from the green stems and leaves the water is not allowed to escape quite unchecked, else it might pass off too fast-faster than it could be supplied.

For anything moist, whether it be moist earth or wet clothes, dries when exposed to the air. The air sucks the moisture out of all, and the drier the air, the more quickly it sucks. Without some protection against this thirsty air, therefore, leaves and green stems would also be sucked dry, like anything else, and accordingly their outer skin is more or less thickened; and it often contains, or is covered by, a waxy deposit as well. We may perhaps have noticed how drops of dew lie upon the leaves without soaking in, so that when the dew is shaken off, the leaves are dry. This is especially noticeable on some shiny 
leaves, but also on some mealy-looking ones, as, for instance, cabbage leaves; and in both cases it is the waxy substance in or upon the skin of the leaf, which not only prevents water from soaking in, but also prevents all but a very small quantity of moisture from being drawn out.

Then, if water is constantly passing off, and that in considerable quantities, how does it escape? A little, as we have said, passes off through the whole surface, but the bulk finds its way out through special openings, pores, or mouths, to which the name of 'stomata' has been given. These pores aré extremely minute openings in the outer skin of leaf and stem, and vary very greatly in size and number in different plants. It is through them that used-up air and water in the form of vapour are allowed to escape.

The process by which vapour is given off through the leaf pores is called 'transpiration,' and is not the same thing as evaporation, though like it, it proceeds more quickly in hot dry weather. But evaporation goes on-or, in other words, the air sucks moisturefrom the whole surface of a plant-from trunk, stem and leaves more or less, and would suck much more than it does if it were not prevented.

Transpiration, on the other hand, is confined to the leaf-pores, and is the process by which the plant parts by its own action, so to say, with its superfluous moisture. In evaporation the plant is merely acted upon by the air; the moisture is sucked out as it is sucked from a wet sheet hung out to dry, or a piece of dead wood. In transpiration the moisture passes out through the proper openings, and the plant itself acts, or at least discharges one of the natural functions of 
its being. Evaporation may continue in a dead plant, but only a living plant transpires.

Both processes are affected by the weather, however, and both in a similar way.

Nothing, we know, dries on a very damp day, because the more moisture the air contains, the less it can take up; or, in other words, evaporation proceeds slowly in moist air. So, too, transpiration almost or quite ceases in damp weather, or when the leaves are wet. But both go on more briskly in the sun, in dry air, and more especially in a drying wind.

The leaf-pores by which transpiration proceeds are usually more abundant on the under surface-the shady side- of the leaves, and are few or altogether wanting on the upper surface, where they would be exposed to the sun, and water might pass off too rapidly. In moist, shady situations there is no danger of too much transpiration, and plants growing in these not only have more leaf-pores than others, but can also have them without risk, both on the under and upper surface of the leaves, for here transpiration goes on more slowly, and the loss of water is also easily made up.

Thick, fleshy leaves have the fewest leaf-pores, and thick, fleshy leaves are particularly characteristic of hot countries, where plants can afford to lose but little of the scanty supply of water which comes to them.

Many leaves which are alike on both sides have about an equal number of pores above and below; but when there is any difference, as, for instance, where one side is dull and the other glossy, the dull side, which is also the under side, has the larger number of 
pores. The leaves of the laurustinus have no leafpores at all on their shiny, upper surface, neither have those of the lilac; while those of the carnation, which show no such difference as these do, have about an equal number on each side. Some leaves have as many as $I 70,000$ pores to the square inch, but this seems to be the largest number. An apple leaf of ordinary size has about roo,00o leaf-pores altogether.

The size of the pores varies very much, but at their largest they are so minute as entirely to exclude the very finest dust. Those of the white lily, for instance, which are called ' remarkably large,' measure only one 4,25 oth part of an inch across.

Hard, evergreen leaves, such as those of the pine, are like the thick, fleshy ones in this, that they have but few leaf-pores, and lose but little water except through these openings. For pines grow in very dry, sandy soils, and often in elevated situations, where the air, though cold, is exceedingly dry and drying, and they therefore need as much protection as plants which grow in hot, dry climates.

Many and various are the devices by which evaporation is checked and controlled, even in temperate latitudes, lest the plant's need of water should exceed the supply. For it must be remembered that air has an immense appetite for water; the drier it is the more it takes up, but it goes on sucking, if allowed, as long as it is in contact with anything containing moisture until it can hold no more.

It is this which makes the misery of an east wind, which is a very dry wind, as well as a cold one, and sucks up moisture wherever it can, not only from vege- 


\section{6}

tation, but from the bodies of animals, drying the skins of human beings, as the hot, dry air of the desert dries them, though in less degree.

Since three-fourths of the weight of most plants, and more of many, is made up of water, the air would be always sucking at them, if not prevented. As things are, however, though some, generally very small, amount of water is sucked by the air from the whole surface of a plant, as we have said, its escape is confined, as far as may be, in most cases, and especially in dry climates, to the legitimate openings, the pores made for this purpose.

Soft, thin leaves lose water by evaporation from the whole surface, and have a large number of pores as well, but they grow in situations where they can easily make up the loss. All leaves, however, have some protection more or less in the skin which covers them, this skin being, moreover, as we have said, impregnated with wax, which, though commonly invisible, often appears as a shiny coating, or as 'bloom.'

A cabbage, for instance, has a mealy look about it, as if it had been dusted with flour; many grasses, acacias, and the now well-known Australian gum-tree or eucalyptus, have a similar appearance, and when this 'bloom' is examined it is found to consist of minute rods, or needles, of wax. The substance forms a regular incrustation on the stem of the Peruvian wax palm, whose native land is one of the most rainless regions of the earth; and there is nothing more effectual than wax for excluding air and preventing evaporation. Honey stored in wax-cells is, as it were, hermctically sealed up and preserved. 
With the wax is often associated resin, which acts in a similarly protecting way apparently. No explanation indeed has hitherto been given of the use to the plant of gums, resins, caoutchouc, and the strong-smelling oils frequently found in leaves; but, as water in which gum or any other substance is dissolved evaporates more slowly than pure water, it seems not unlikely that one at least of the uses of these substances is to check the escape of water. And this seems the more probable when we consider that aromatic, as well as gum and resin-bearing, plants are especially characteristic of deserts and dry regions, hot or cold. Thus the pine-tree of the north has its turpentine, the eucalyptus of hot, dry Australia its oil, and the acacias of Africa their gums.

Many trees and shrubs in hot, dry countries are protected also by having either small or very few leaves, or even none at all.

Where the air is constantly damp, as it is in many parts of the tropics, there the trees may boldly venture, as the plantain does, to spread broad leaves many feet square to the sun, for the water-supply never fails, and the air is not outrageously thirsty, as it is in the desert. But in those parts of Australia where rain is scanty and droughts are frequent, there the leaves are not only small, as we have said, but they, most of them, also protect themselves by turning only their edges, not their broad sides, to the sun; for they have to economize their resources as much as possible. This is particularly the case with many species of Eucalyptus, some of which turn one leaf-edge to the earth and the other to the sky, or stand erect, turning one edge towards the stem and the other away from it, in each 
case exposing themselves as little as possible. Their leaves, too, are for the most part narrow, and so scantily distributed over the branches that an Australian forest has none of the deep shade which the word naturally suggests to us.

But when the eucalyptus is transported to other lands, where it has plenty of deep, rich soil, and moisture in abundance, then it puts on more foliage, showing that it was only the dry heat of its native climate which made it so sparing of its leaves.

Most of the many species of acacia found in Australia go even a step beyond the eucalyptus in the way of economizing their foliage, and give up having any true leaves at all as soon as they are full-grown. They keep their leaf-stalks indeed, but there are no leaves at the end of them, and instead there are 'wings,' or narrow, leaf-like margins, growing out from each side of the stalks. Even these 'wings ' do not venture to face the sun, but turn their edges to earth and sky.

Acacias are especially the trees of deserts; they are, indeed, the only timber-trees of the Arabian Desert, and they abound in Africa, as also in Australia. But wherever they grow they are characterized by the lightness of their foliage; and of the Australian species, which number something under three hundred, two hundred and seventy drop their leaves altogether when they are grown up, and merely flatten out their leafstalks as described.

None of the Cactus family-which are natives of the hot, dry regions of America, North, South, and Central-make any attempt at having leaves or even 'wings, but their stems are flattened out and do 


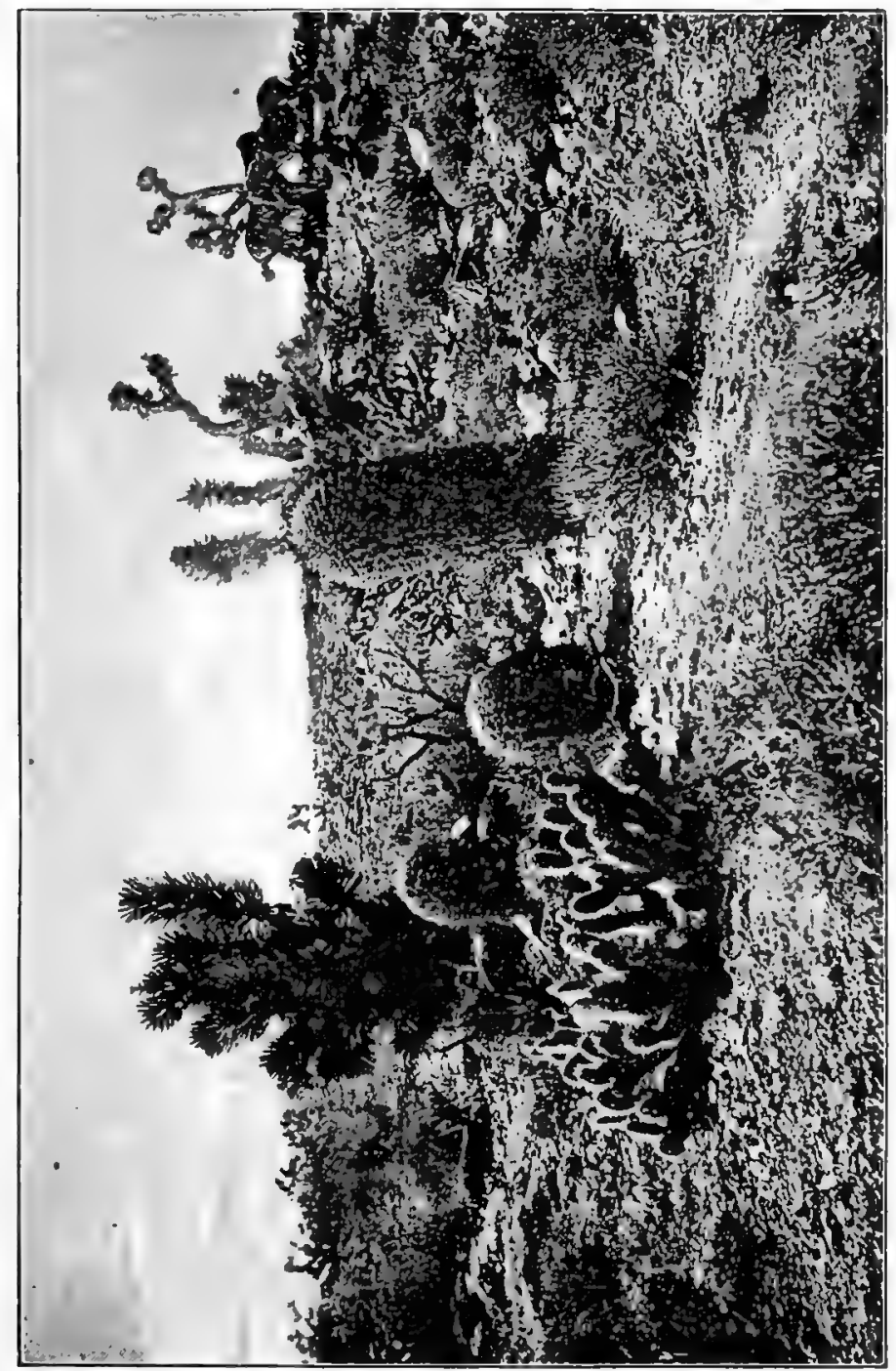



duty instead. The stems, too, are protected against evaporation by being enveloped in a peculiar leathery skin, which is thickest in the species inhabiting the hottest and driest regions; and they lose little water therefore, except through the pores, which are but few in number. Thus protected, they not only exist, but flourish, in dry sand, where for three-quarters of the year they are exposed to the blazing, parching sun.

The tall, fluted columns of the species of cactus called the 'Torch Thistle,' sometimes fifty feet high, are to be seen springing out of crevices in the hard rock, and standing up like telegraph-posts on the mountains and in the rocky valleys all over the hot, parched, almost desert regions of New Mexico.

This tall cactus seems to be so fully protected by its thick skin that it may venture to expose its whole surface to the sun without risk; but other species are less bold, and keep close to the ground, growing in the form of large cushions or great globular masses, and so diminishing the extent of exposed surface. Some, too, are set all over with long, slender, needle-like spines, and are also covered with what look like dense masses of floss silk, both of which protect the plant from the hot air and sun.

But though these special means of defence are more striking in the tropics than elsewhere, they are employed more or less everywhere, our own moist land not excepted. Besides the bark, and the cork, and the more or less thick skin of the leaves, and the wax, which we have already mentioned as the ordinary means by which evaporation is checked, these other measures are also frequently adopted for securing the 
same end. Our plants do not indeed go so far as to drop their leaves altogether, but some of them do greatly diminish both their number and size; and some clothe themselves with hairs, partly, as it would seem, lest they should be deprived of too much moisture, though partly also, probably, as a protection against insects. An example or two of these must suffice, and we will take, first, that of the Amphibious Persicariaa particularly interesting plant, as it grows both on land and in water, and adapts itself to its situation in a very marked manner. When it grows in water, where, of course, it does not matter how much it may lose, it has smooth, lance-shaped leaves; but when it grows on land the leaves are narrower, and not only this, but they are covered as well with a quantity of long hairs, pressed close upon the surface, which they protect against evaporation.

Then there is the Sweet Woodruff, whose lanceshaped leaves grow in whorls of eight, for the plant dwells in moist, shady places, where there is no risk in having many leaves. But look from this to another member of the family, the Quinsy Wort, and what do we find? The leaves are very narrow, and there are but half as many of them. Why? Because this little plant grows on dry banks, where many and large leaves would be dangerous to its welfare.

It has been already mentioned that the Pine family, which thrive in dry, sandy soils, have hard, needle-like leaves, with few pores, and therefore give off but little water, either by evaporation or transpiration; and it is for this reason that the air in a pine forest in summer has none of the coolness which one finds in a forest of what the Germans call 'leaf-trees,' The 'needles' of 
the pine they do not consider worthy the name of leaves.

Leaf-trees are continually cooling the air by the moisture which they give up to it; but the pineneedles have so few pores, and are so very much protected, that the little water they part with is not enough to produce any appreciable effect upon the air.

It is, perhaps, hardly necessary to do more than remind our readers that the evaporation of water is always accompanied by the absorption of heat, or, in other words, that water cannot be converted into gas or vapour, which it is when evaporated, without using up heat. Whether it be the heat of a fire or the heat of the sun, it is all the same. A certain amount of heat is required to make water pass from the liquid to the gaseous state, and if this heat be taken from the air, the air is necessarily by so much the cooler.

And this brings us to another part of the subject, the question, namely, as to the amount of water given off by trees and other plants, notwithstanding the various ways in which, as we have seen, they are protected.

We have distinguished hitherto between the two processes of evaporation and transpiration, because they are distinct; the one being due to the action of the air, and the other to the action, so to say, of the plant. Evaporation takes place whenever air comes in contact with anything moister than itself; whether it be animal or vegetable, whether it be wet earth or damp clothes, from all it draws water, and by its own heat converts this water into vapour. The other process, transpiration, is that by which, through the pores-the openings left in the skin of stem and leaf- 
the plant gives up, in a regular, systematic manner, the moisture with which it would else be overcharged.

But in both cases the water passes off into the air in the form of vapour; and in both cases it passes off as nearly pure water, all mineral matter being left behind; in both cases also, the amount given off varies with the weather, there being more loss on a hot, dry, sunny, or windy day, than on a damp, dull, still one. When, therefore, we consider the amount of water which passes off into the air from a plant in a certain time, it is generally impossible to distinguish between that which comes through the whole surface and that which comes through the pores; and both processes are frequently spoken of together as transpiration or evaporation. The quantity transpired is, however, usually very much larger than the quantity evaporated.

In some plants it is occasionally possible to see the moisture coming from the leaf-pores, as it escapes faster than the air can evaporate it. This is the case with many grasses, especially the maize, which may be seen studded with actual drops of water.

A grass-plant gives up its own weight of water in the course of twenty-four hours, in hot, dry weather; and a square foot of turf will yield more than $\mathrm{I} \frac{\mathrm{x}}{\mathrm{B}}$ pints of water in this time. But a square foot of long pasture-grass gives off nearly $4 \frac{2}{5}$ pints, or as much as Io6 tons of water to the acre!

The larger the surface, the larger of course the amount of water which passes off from it ; and therefore the extent of surface exposed is a matter of great importance, though it is also one which we are very likely to overlook, at least in many cases. Of course we can all see that a tropical plantain with its broad, 
large leaves, has a considerable surface exposed to sun and air ; and so with other conspicuously large-leaved plants. But when, instead of a few large leaves, a plant has many small ones, it is not so easy to realize what the whole surface may amount to.

A sun-flower, for instance, has leaves of a good size, and yet it is rather surprising to find that in a plant only three feet and a half high, the whole leaf-surface may amount to more than thirty-two square feet! One specimen of this size was found to give up from a pint to a pint and a half of water during a day of twelve hours. The sun-flower is quite outdone by the cabbage, however, one specimen of which gave off nearly two pints and a half in twenty-four hours, and that from leaves which, had they been spread out, would have covered only nineteen square feet. We have seen how well the cabbage is protected by its wax coating against evaporation, so that almost the whole of this amount is given off by the plant's own action. The camellia is much less thirsty; it has fewer pores, and its thick, glossy leaves are so efficiently protected, that half an ounce of water, $\frac{1}{10}$ pint to the square foot of foliage, was all that one plant gave up in a day and night.

These calculations are comparatively simple; but, when we come to trees, who would venture to guess at the extent of surface exposed to the air and sun by the leaves upon an elm? We look up at the quivering multitudes, and feel as if it were hopeless for anyone even to attempt to count them; it is too bewildering !

Yet the calculation has been made, and the leaves on a not very large elm-tree are said to be about $7,000,000$, which would give a surface of about 200,000 square feet, or five acres! 
From the whole of these five acres of green surface, water passes off into the air in the form of vapour, to the amount of seven tons and three-quarters during each twelve hours of clear, dry weather.

But if this is the quantity returned to the air by a single tree of only moderate size, how large must be the amount received from a wood or forest, containing hundreds or thousands of trees! 


\section{IX.}

DESERTS

From what has been already said, it is evident that every tree, every plant, every spire of grass indeed, is a pumping apparatus on a larger or smaller scale, by which a portion at least of the water which descends from the clouds begins to mount up again almost as soon as it has fallen.

Plants give up to the air, chiefly by transpiration through their leaf-pores, but partly also by evaporation from their whole surface, nearly as much water as is taken up by their roots-nearly, but not quite-for, as long as they are growing, they need some water for the formation of new shoots and leaves. The quantity is not much in itself, though water makes up a large part of the weight of most plants. But it is quite clear that, without water, they cannot grow at all.

Provided a plant has a plentiful supply of water, enough, that is, to make up for what it loses, it does not seem to matter how much it transpires. Some plants thrive perfectly well in dry air-where they give off moisture constantly and rapidly-if only their roots be kept in damp soil ; and others thrive equally well in comparatively dry soil, provided the air be damp enough 
to check transpiration and allow them to retain most of the moisture they draw up. But, when once a plant has thoroughly flagged, the case is different. Then, nothing short of water supplied to the roots will be sufficient to revive it. Damp air will be of no use; neither will the heaviest dew avail anything. The roots, and the roots only, can furnish the necessary supply.

Of course every substance-even, as we have seen, the hardest rocks-will absorb some amount of water when actually steeped in it; and so, if a withered shoot is kept soaking in water, it will absorb a certain quantity in time, as any piece of dead wood does. But leaves and stems have little or no power of absorbing moisture from the air.

This is the general rule, to which there are a few, but only a few, exceptions; lichens, which have no roots, do draw moisture from the air, and would be badly off if they could not, considering the bare rocks upon which they grow. Mosses, too, which grow where there is little or no soil, also supply themselves with moisture from the air to a great extent; and so it is believed do plants, such as the mistletoe, which grow upon others.

But still the general rule holds good; leaves have little or no power of absorbing moisture either from the air or from water poured upon them.

And yet, how the drooping leaves revive on a dewy evening, or in a shower of rain, or even under the influence of a shower from the watering-pot! The water cannot surely have had time to reach the roots, and then to travel up the stem.

Water certainly does travel upwards with amazing 
rapidity in some plants, as will be seen presently; but when leaves revive on a dewy evening, or during a shower, it is not because they have drunk in any of these fresh supplies. Moisture is constantly passing up to them in larger or smaller quantities from below; but they part with it nearly as fast as they receive it generally, and faster than they receive it in dry weather. It is the want of sufficient moisture which makes them droop and renders them flabby. But when the dew falls on them transpiration ceases, or nearly so; they are able to keep nearly all the moisture sent up to them, and so they swell out again and stiffen, and hold themselves up.

A similar effect may be seen even in cut shoots which have been allowed to fade, and are then placed in very damp air. No moisture is taken up; quite the contrary; the continued decrease in their weight shows that moisture is passing off into the air, little by little, all the time; but stem and leaves are losing it very much more slowly than they did in ordinary air; and as water from the lower, older parts of the stem continues to rise, as it did before the shoot was severed from the tree, so the younger parts at the top, the leaves and buds, are refreshed and revived. Of course, this can go on only for a time, so long, that is, as any of the original moisture is left in the stem; and when this is exhausted the leaves droop as before, and at last wither entirely.

And now to gain some idea, if we can, of the rate at which water travels upwards from the roots to the leaves of a plant. This of course varies enormously in different plants, because some transpire so very much more than others; and it also varies greatly at different 
seasons of the year, according as the plant is growing, or putting out buds and leaves, or not.

Experiments made by watering plants with coloured solutions are not very satisfactory, because the colouring matter may be caught and entangled, while the water moves on without them. Still, it is interesting to learn that in the case of a white iris, which was watered with a blue solution, the white petals were streaked with colour in from ten to fifteen hours.

A more trustworthy experiment made upon a willow seemed to show that the water in this case rose from the roots at a very much more rapid rate-thirty-four inches an hour. But the willow, having its roots always in or near water, has no need to be economical.

In a plant of maize, whose roots were in earth, the rate was much less, being little more than $\mathrm{I}_{4}$ inches per hour; in a sunflower it was 25 inches; but in a tobacco-plant it was $47 \frac{1}{2}$ inches per hour. The tobacco transpires so freely that its leaves droop as soon as gathered, and these experiments were made in such a way as to encourage transpiration to the utmost.

In some plants the sap rises with extraordinary rapidity; as, for instance, the Water-liana. This is one of the many gigantic, rope-like creepers or 'vines ' of tropical America, and owes its name to the fact that clear, cool water fit for drinking can be obtained from its stem-by those, at least, who know how to proceed.

These climbers mount up among the trees far overhead, so that to cut off the top of one is quite impossible. A length of some seven feet has to be cut out where it is within reach, and this piece will yield about a pint of water; but it must be cut first at the top, 
otherwise, if cut first near the ground, almost the whole of the water will have rushed away into the vine high overhead before the second cut can be made.

This plant therefore seems to dispose of a pint of water in less than a minute, and almost all by transpiration, since the quantity evaporated and the quantity required for growth, in one minute, must be exceedingly small. At this rate the liana pumps up from the ground 60 pints of water in an hour -720 pints, or go gallons, in a day of twelve hours.

In early spring, when the sap is beginning to rise, the sugar-maple will sometimes yield as much as seven or eight gallons every day for three weeks, and this, of course, does not represent more than a small portion of the water which the tree has taken up, as it is only tapped, not drained of moisture. But the maple is far outdone by the Black Birch, another of the American trees from which sugar is made; for one specimen of this yielded, in four or five weeks, the extraordinary quantity of about 1,890 gallons. And this, like the sap yielded by the maple, is only a part, and a small part, of the moisture which the tree has drawn from the earth, and would in the natural course of things return to the air, diminished only by the small supply needed for fresh shoots and leaves.

But the amount of water which a plant takes up does not depend solely on the soil and climate in which it grows, but also on the plant itself. There is a wonderful difference in the power which plants possess of supplying themselves with food and water. Just as one man will live, and even thrive, where another would starve, so it is with vegetables. The lichen makes a living off the bare rock, where nothing else can grow; 
and the ice-plant carpets some of the most arid rocks of Greece, even after months of drought, and looks, too, just as deliciously cool as ever, its fleshy leaves being still covered with their characteristic 'frosting,' against which the hottest sun is powerless. On closer examination the coating of 'frost' turns out to be composed of innumerable globules of water contained in the surface-cells- the skin-of the leaf. A prick with a needle shows that these globules are just tiny bladders filled with water; but this skin is so exceedingly thin, and so perfectly transparent, that it is a mystery how the plants manage to keep their moisture; and it is often no less a mystery how they manage to obtain it in the first instance.

An English meadow, again, would wither and turn brown if it were left unwatered beneath the fierce heat of a tropical sun, but the grasses of the Kalahari desert of South Africa remain surprisingly green, though they get but one or two falls of rain in the course of the whole year. Sometimes they get no rain at all for a twelvemonth; but even then, when they are the colour of hay, they are equal to hay of ordinary quality as fodder for cattle, and hence are of course still very valuable. The wonder is how they manage to keep any life at all, and any nourishment in them, after so many months of burning drought.

In parts of Texas, where also rain is quite the exception, the grass is often destroyed during the hot months; but other green things contrive to exist, and these supply its place to the cattle. Timber is scarce in these parts; but within the last twenty years thickets of 'mesquite' have sprung up, and now cover miles of prairie, where formerly there were none. And 
a most valuable tree the 'mesquite' is, not only for fuel, fences, and for the framework of houses, but for food. Its light foliage takes the place of grass during the hot season, while its beans supply the cattle with abundant food in winter; and it is enabled to bear the drought by the fact that it has huge roots, which weigh hundreds of pounds when the tree is only a few feet high.

But the Prickly Pear cactus is almost equally useful, so far as the cattle are concerned, and it covers prairies so vast that the supply is simply inexhaustible. In spite of drought, and heat, and dry soil, the thick stem-like leaves, or leaf-like stems, hold an enormous quantity of moisture, and when the thorns have been burnt off even sheep can live and grow fat upon it. For horses and cows it is split open, and they eat out the inside, which is so succulent as to answer the purpose of drink as well as food. One can hardly imagine any other way in which water could be so successfully stored in these arid districts as within the thick leathery skin of the cactus.

But the gourd family are almost as wonderful in the way in which they manage to appropriate and keep possession of water, even under the driest circumstances.

A pumpkin is all water, with the exception of five and a half per cent. of its weight; and yet large pumpkins may be seen growing in what looks like nothing but sand. To be sure, their thick rinds enable them to keep the water when they get it, and sand is liberal in the way of parting with its moisture; but even so, knowing how very watery they are, it is strange to see them growing in such dry soil. Plants of this kind, 
however-gourds and melons-are especially characteristic of so-called 'desert ' regions, which are exposed to long-continued droughts.

Whenever there is more rain than usual vast tracts of desert land in South Africa are covered with melons, which provide food and drink both for man and beast. The sama, or wild water-melon of the Kalahari, grows in great abundance in many parts of this desert; and the fruit, which remains good for a year in dry seasons, affords the natives almost their only supply of water when they are journeying across this rainless region. Evidently, therefore, the sama is able to make the most of its limited opportunities, and can not only appropriate, but also keep, moisture, where most plants would simply perish of thirst.

Trying as are the droughts of the South African desert, they are less severe than those of Australia, for at all events such rain as does fall is kept, and sinks into the sub-soil, there being no rivers to drain it away; whereas in Australia the rivers quickly carry it off again. Even here, however, some trees, and among them the eucalypti, manage to store water in their roots; and from this supply the natives were in the habit of helping themselves in time of need. The long side roots were laid bare, as much as twenty or thirty feet, and divided into short lengths, from which water dripped at once, clear, cool, and free from any unpleasant taste or smell.

How the water remains so cool, buried only from six to twelve inches beneath the burning surface, is one of the many mysteries connected with the great mystery of life.

Water in a pipe, from which there was little or no 


\section{Deserts}

evaporation, and water in a dead root, would speedily grow warm under similar circumstances. Water in a porous vessel keeps cool, indeed, in the hottest sun, because the vessel is porous, and water is constantly passing through it and being turned into vapour; with the result that the air immediately surrounding the vessel is being constantly cooled. The water is turned into vapour by means of the heat abstracted from the air.

But the water in the roots of the eucalyptus is not kept cool by evaporation; else, in time of drought, it would be evaporated altogether. Besides, the juice of the hard, leathery-skinned pomegranate is cool on the hottest day; so, too, is that of the melon, with its thick rind; and the abundant juice of the thick-skinned mango feels as cold as iced water, even under the blazing sun of Ceylon; though the evaporation from any one of these must be very slight indeed.

Moreover, the coolness lasts only while the fruit remains on the plant, and disappears in a few minutes after it is gathered. It must, therefore, be quite independent of evaporation, and the temperature of a living plant's juices must be like the temperature of the blood in men and animals, quite independent of climate.

The ordinary temperature of the blood of human beings $\left(98^{\circ} \mathrm{F}\right.$.) remains the same whether they live under the equator or in the Arctic regions.

And so it is with plants. They are cold-blooded, so to say, and cold-blooded they remain, even when surrounded by hot air, as long as they are alive. When they are dead their temperature soon rises or falls, according as the surrounding air is hot or cold. But 
if, while alive, the temperature of their sap were affected by climate, or by the changes of summer and winter, day and night, then not only would it be constantly frozen in the far north, and not far short of boiling in the tropics; but the sap of an acacia of the desert might freeze by night and almost boil by daya sudden and violent change, which, as has been shown, wears out the very rocks.

But to return to the 'deserts,' by which we are to understand those regions where water is scarce, drought frequent, and where vegetation, though seldom or never entirely absent, is more or less scanty, and more or less, peculiar, because it is especially adapted to the special circumstances of its situation.

The soil of the desert may, or may not, be poor, but it is the want of water which renders these regions comparatively barren.

Well-watered, the Kalahari desert might, it is said, be one of the richest grazing lands in the world; and the utter barrenness of certain tracts of the Sahara is owing merely to the lack of rain, for the soil beneath the sand is actually rich, and is not only quite capable of supporting vegetable life, but is extremely fertile wherever there is moisture.

The other marked characteristic of desert-lands is the dearth, if not absence, of trees, and the question we have now to consider is whether these two characteristics-the want of water and the scarcity of all vegetation, but especially of trees-are brought about the one by the other.

Vegetation cannot thrive, though it may manage to exist, without a regular supply of water; but does vegetation bring rain or increase the rainfall? 


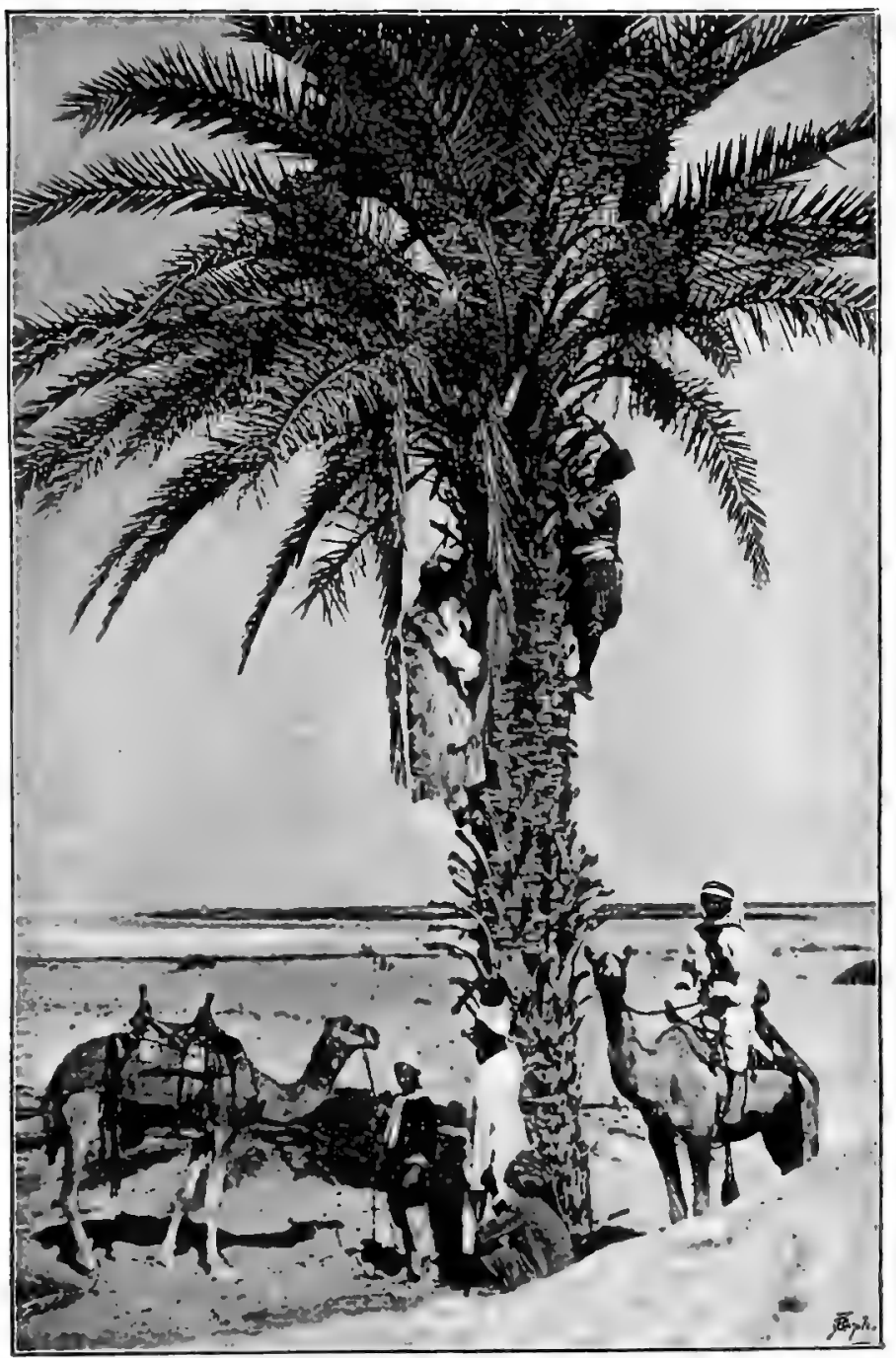





\section{Deserts}

There is no doubt whatever that where forests have been recklessly destroyed there the climate has been most seriously injured. The Ceylon coffee-planters cut down forests to make more room for their plantations, and many of them were ruined in consequence. The trees were gone, but so, to a large extent, was the rain also; and the additional space gained was valueless, for the coffee could not grow for lack of moisture.

So, also, the destruction of the olive-trees in Palestine has diminished the rainfall there, and with the rainfall the productiveness of the land, for centuries past. Now that trees have been planted again the rain is said to be returning.

So much, then, is certain : cut down forests and you will have less rain; and, though the natives of Namaqua Land, South Africa, attributed the great diminution in their rainfall to the presence of the missionaries, others had no hesitation in ascribing it to their own wasteful way of cutting wood.

But though loss of forest brings loss of rain, it is difficult to say precisely how the change is brought about, and whether rain is actually caused by transpiration or not.

Wherever there is vegetation, be it grass or be it forest, there, as has been shown, large quantities of water are constantly passing off into the air in the form of vapour. And the amount is large, not merely considering the means by which it is pumped up, but it is large actually ; very large, when we compare it with the amount of rain which falls.

For instance, from the record kept at Greenwich it appears that during July, our wettest month, the average fall of rain is something under three hundred 
tons to the acre, or under three inches-three hundred tons during the whole month, or less than ten tons each day. But an acre of pasture-grass actually gives up more than ten times this quantity in the course of twenty-four hours-106 tons-that is to say, in a single day and a night. So that an acre of pasture which has received three hundred tons of rain in a month, gives up more than three thousand tons in the same time.

The question as to where this immense quantity comes from will have to be considered later. At present we are concerned only with the fact that so much water is returned to the air. Whether it falls again on the same spot is another matter, and we have no proof that it does so. It may do so under certain circumstances, or it may be carried away by the wind and fall elsewhere, perhaps close by, or perhaps a long way off.

But if the air immediately over a certain district is being constantly cooled by the evaporation day after day of large quantities of water, does this produce no effect upon the air above?

What happens when water is boiled over a fire? Clouds of visible vapour rise from it, which we commonly call 'steam.' They are not properly steam, however, for steam is invisible. These are clouds, true clouds, consisting of minute globules of water, steam made visible, converted into water again by coming into contact with the air of the room, which is cooler than that within the kettle.

As heat converts water into gas or steam, so cold turns it back into water again. So when the earth is chilled at night the moisture of the air is also chilled 
on a large scale, and dew is formed-first on grass and leaves, because they are cooler than the soil.

If this be so, then when a current of warm moist air comes in contact with the cool air over a forest, or over acres of pasture, will not some of its moisture be condensed into a cloud, as the steam from a kettle is condensed into a cloud when it escapes into the air, and may not this cloud discharge itself upon the grass or the trees?

Of course the cloud may be carried away; but it seems likely that, in some cases at all events, it will water the district above which it is formed.

There is a further question as to whether trees actually attract the clouds or not, and this still waits for a satisfactory answer; but it is certainly the popular opinion that they do, and it is a very common thing to hear it said that the clouds have gone over to a neighbouring park or wood, when the farmer would have been better pleased that they should water his fields.

As we began by saying, the subject is a difficult one; but though we may not be able to explain precisely the how, there is no doubt at all as to the fact that the presence or absence of all vegetation, not of trees only does very greatly affect climate, and the climate in its turn affects vegetation.

For instance, Tacitus, the Latin historian, writing some eighteen hundred years ago, mentions that not even a cherry would ripen on the banks of the Rhine; and he certainly would not have believed that in centuries to come the same region would have become warm enough to be famous for its vineyards. But in his day forests abounded all about the river, and it is the removal, or great diminution, of these which 
has raised the temperature. A similar, but in this case disastrous, result has been produced on the southern slope of the Pyrenees, where what once were wide fertile tracts, covered with vegetation, have been turned into wastes by the destruction of the forests too recklessly carried out.

Wooded countries certainly seem on the whole to receive most rain; and the clearing away of any kind of vegetation, be it herbage, brushwood, or forest-trees, may be, and often has been, attended by evil consequences. For vegetation protects the soil from evaporation, enabling it at least to keep what water it receives, and, as this accumulates, springs, or reservoirs, are formed, from which the plants in their turn may derive supplies when rain fails or is insufficient.

Then again, vegetation preserves the soil from the assaults of wind and rain, a matter of no small importance, especially in mountain regions, for, as we have already seen, the earth on the slopes may be clean washed or blown away, and the fertility of centuries may be thus destroyed.

But even this is not all. The soil gone, what remains?

Bare rock or subsoil, which is dried and heated by the sun, growing drier and therefore hotter, till it is quite parched. But a dry, hot surface heats and dries the air above it, for hot air, being lighter than cold, rises.

From a wide expanse of dry hot sand, such as that of the Sahara, therefore, there must be a constant upward current of hot air, and this, again, must act like a furnace upon any moist current with which it 


\section{Deserts}

comes in contact. The moisture has no chance of condensing into a cloud, or rain, as it might if it met with cool air, but is dispersed-drunk up and evaporated by the hot, thirsty air from below. No wonder, therefore, that the Sahara is a rainless region.

The island of St. Helena, again, is a notable instance of what man can do in the way of reducing a luxuriant garden to a barren waste, simply by his ignorant or reckless destruction of its natural vegetation. When first discovered, the island, though very mountainous and bounded by tremendous precipices rising some two or three thousand feet above the sea, was very fertile, and possessed a luxuriant growth of forest. For it is astonishing what a thin film of soil is enough for seeds to sprout in, if only it be moist; and it is astonishing, too, how little soil will suffice even for hardy evergreens, birches, and other small trees, whose roots often grow in immediate contact with the rock. But one thing is absolutely necessary. If the soil be shallow, moisture must be abundant.

The soil of St. Helena was rich, being formed by the slow decay of volcanic rocks, but it was not deep, and was only kept in place by the roots which held it fast. The Portuguese brought goats to the island, and by these destructive animals the luxuriant vegetation was in great part destroyed, for they multiplied by thousands. There was a wanton waste of wood, too, on the part of the human inhabitants, though some were far-sighted enough to predict that the island would be ruined when the 'Great Wood' was destroyed. And so, sure enough, it was.

Gradually the soil became more and more exposed, and whenever this was the case, it was washed away 
by the violent rains, leaving bare rock and utter barrenness behind. Still the destruction was allowed to go on, until, as the timber rapidly vanished, not only did the soil follow, but the rain deserted it also, and the Governor, taking alarm, reported that the island, hitherto abundantly watered, was beginning to suffer from drought.

But the authorities-the island was then in the hands of the Hon. E. I. C.-were not to be persuaded that there was any connection between the loss of trees and the want of rain, and returned for answer that the goats were more valuable than the ebonytrees, and were not to be destroyed. So the goats stayed, and the ebony-trees went; and the general aspect of St. Helena became that of a dreary rocky desert.

On the other hand, a change greatly for the better has taken place in the region round about the Suez Canal. Here there was formerly hardly a blade of grass to be seen, and the land was a desert. But the cutting of the canal has brought water into the midst of the parched land; this soaks through the sandy soil, and everywhere herbage is springing up along the banks. Rain is still rare, but the air is moister; for the blazing sun draws up from the canal large volumes of water, which, though it is only invisible vapour by day, is chilled and condensed into water again by the lower temperature of the night, and falls upon the thirsty land as a heavy, refreshing dew.

But the very fact that it is a sandy district is in its favour in one way, for water soaks easily through it, and is thus brought to the roots of all plants growing within reach, 
Then, again, in the Delta of Egypt there is much more cultivation than there was some years back. There are more cornfields, more pastures, and even little forests are springing up, so that its general aspect is quite altered, and this change is accompanied by a change for the better in the climate also. Alexandria has rain, even to excess; and Cairo, which used to have at most five or six light showers a year, now has three or four times as much. The increase in the rainfall seems to be distinctly traceable to the increase in the amount of vegetation.

So impressed are the Americans of the West with the connection between want of trees and want of rain, that they now set apart a day in each year, which they call 'Arbor-day,' and dedicate to the planting of trees. Before this idea was started there had been such reckless cutting of wood in the mountains and timber regions as to cause quite a dearth even of fire-wood, especially in what is called the 'arid-region' of the Western States. Now, however, more than six million trees are said to be growing on formerly barren lands, and Kansas alone has 2,50,000 acres of artificial forest growing up-a change which it is expected will so benefit the whole region that it will cease to be arid.

In this land we have little idea of the magic change produced in the appearance of the landscape by rain falling upon the hot, parched surface in southern latitudes. There, growth is so rapid that, in Ceylon for instance, a green hue begins to colour the saturated ground after a single day's rain, almost between dawn and sunset, where all before was dreary brown.

But the change which takes place in the desert of Nubia is far more wonderful. During the dry season 
not a blade of even withered grass is to be seen; trees and bushes have shed their leaves-their very bark is cracked by the fierce heat. The Atbara-that mighty tributary of the Nile, to which its yearly inundations are due-has altogether ceased to flow, and is converted into a barren waste of glaring sand, four or five hundred yards wide, interspersed with a few pools here and there. And yet the tremendous torrents which pour down into it from the Abyssinian highlands have never ceased to flow; but the whole of their waters, to the last drop, have been evaporated on the way by the intense heat, or have been absorbed by the desert-sand which has accumulated in the bed of the river. Everything is parched, scorched, gasping; not only the sand, but the air is burning.

Such is the state of things towards the end of June: the Atbara is dead!

Then one night, when everything is suffocating, there comes, suddenly, without warning of any kind, a sound as of distant thunder, a continuous roll and roar, which means that the river has arrived!

There, where there was only sand the day before, it flows five hundred yards wide, a mighty flood, and already fifteen to twenty feet deep; for the rain is pouring down upon the great table-land of Abyssinia, and it will continue to pour for two or three months to come.

And the change in all the bare and withered trees and shrubs, how rapid and how marvellous it is! In two days' time they show signs of bursting into leaf, having previously looked as dead as they do with us in winter; and as for the mimosas - their light, feathery foliage is already, beginning to afford shade. 


\section{Deserts}

Yet there has not been a drop of rain, or even of dew. The air no doubt is moister, for evaporation from this wide expanse of water must go on at a tremendous rate. But at present it is too hot and dry to part with a single drop; and it is from the soil that the trees have received their fresh supplies, so quickly does the water soak through the sand. But this is not all that they will get. All nature seems to expect a change, for the wind is blowing from the south, and rain is surely coming!

The natives of South Africa say that the wind ' smells of green grass' when the wind blows from a quarter where rain has fallen, though this may be hundreds of miles away; and thousands of cattle will start off sometimes and travel immense distances, in the endeavour to reach the fresh pastures of which the wind tells them. So keen is the scent of men and animals in lands which suffer from long drought. 


\section{$\mathbf{X}$.}

\section{ROOTS}

Plants, as we have seen, need a constant supply of water for transpiration and for growth. They cannot, as a general rule, take this in by their leaves, and therefore must take it in by their roots; and without water the roots cannot take up and supply to stem, branches, leaves, flowers, and fruit that mineral matter without which the plant cannot exist.

Before examining the way in which the roots perform their work of supplying all parts of the plant with liquid food, we must briefly consider where the water comes from.

For if, as has been said, the ordinary rainfall in England for the whole month of July is about 300 tons, and if an acre of pasture-grass transpires more than 3,000 tons in the same time, it is quite evident that the demand far exceeds the supply from the clouds. Moreover, the grass does not get even the full benefit of that which does fall, for a very large proportion is either at once evaporated from the soil, or is drained away into ponds, lakes, streams, or rivers.

Of the rain which falls in England between April I 
and October I, it has been calculated that go per cent. is evaporated from the soil and returned to the air. From the air, however, the soil again absorbs it; for though leaves do not absorb moisture from the air, the soil does.

We speak commonly of the air as being 'damp' or 'dry,' as the case may be; but in point of fact it is never absolutely dry, for nothing could live in it if it were. It always contains some amount of watery vapour, and, whether it be large or small, soil which has been dried during the day regains some degree of moisture by night by the simple process of sucking it from the air. The air sucks it from the soil by day, especially during sunshine or dry wind, and the soil thus dried sucks it back again at night.

Some soils suck much more moisture from the air than others, and some are also able to keep it much longer than others. We all know that a sandy soil; for instance, is a dry soil : it takes some time to grow really damp, and it dries again very quickly. Indeed, pure quarţz-sand seems as if it could not be moistened by anything short of rain or dew, being insapable of sucking any moisture from the very dampest air.

A chalk or limestone soil, on the other hand, acts like a sponge, and, though it may dry on the surface, keeps its moisture a long time within. The subsoil of the Kalahari Desert, already mentioned, is limestone ; and this is probably one reason why the grass there is able to remain green so long without rain. Such water as is received is kept for some time, stored up in the subsoil. 
Of all kinds of soils, it is those containing most vegetable matter which take up most moisture, and also remain damp the longest.

It is a curious fact, however, that the soils which are least ready to part with their moisture to the air are also those which are least ready to part with it to the roots of plants. There may be actually more moisture in vegetable mould than in sand; but the latter, at all events, makes the plants welcome to what there is, and lets them have almost every drop; while the mould may have more to give, but also keeps back more. If the two contained an equal amount of water, therefore, plants would actually be better off for moisture in the sand than in the mould; but this is not the case.

An experiment made for the purpose of trying different soils with regard to their readiness to give up their moisture to the roots of plants gave some very interesting results: the soils chosen were three -I, loam; 2, a mixture of vegetable mould and sand; and 3, coarse sand alone; the loam held two and a half times as much moisture as the sand, and the sand and mould mixed held more than twice as much.

In these three soils were placed some tobacco plants, which are very thirsty and very watery-four-fifths water, indeed. Their broad, tender leaves begin to droop as soon as gathered owing to their rapid transpiration. The sand gave up the whole of the water it contained with the exception of one and a half per cent., and it was not until it had reached this dry state that the tobacco planted in it flagged; the other plants flagged when the loam still contained eight per cent., 


\section{Roots}

and the vegetable mould and sand a fraction over twelve and a quarter per cent.

The supply contained in the sand was exhausted first, of course, because it contained so much less to start with; but, though the other soils were not nearly as dry, the plants flagged because they could not get hold of the water which they still contained.

Some plants, such as rice, grow equally well in soil or water, but most plants are injured by having their roots kept in water for any length of time, and are, as a rule, in better health when allowed to take up the moisture they need from that which is contained, invisibly, in the pores of the soil, when it does not look actually wet at all, and no moisture could be squeezed out of it.

But our main point now is to show that soil may, and does, become damp without rain. It may be dried by sun and wind by day, but it makes up for this by drawing moisture from the air by night, and it is this, partly, which enables plants at least to live through a time of drought, though their very stunted growth shows that the supply has been insufficient for their needs.

The moisture which the soil thus draws from the air does not remain on the surface, but, like the rain and dew, sinks into the ground, penetrating deeper and deeper, and moistening the soil until it is used up, or stopped by meeting either with damp soil, or with soil or rock through which it cannot pass. Rain falling upon a porous soil, such as sand, or even soil containing much sand, passes quickly through it until it meets with a bed of stiff clay or rock, which prevents its going further; and then what is left, over and above what the 
soil has taken up, accumulates, and may in time form a spring, or even a sheet of water. In some places there are known to be very extensive underground lakes, and these must do much to keep the soil above them moist in the absence of rain. The springs, or underground streams, too, do the same, and in some cases they flow such long distances that it seems not unlikely the Kalahari Desert may have some such subterranean supply of wazer, which enables the plants to live through the long terrible drought.

But, it may be asked, what is the use to the plants of water so far beneath as to be quite beyond the reach of their roots? The answer to which is that it does not remain beyond their reach, but is brought up to them.

The water in the soil, visible or invisible, is like a stream which is never at rest; it is in constant motion, always either rising or sinking according as the surface of the soil is damp or dry.

When the surface is wet from rain, the rain goes on sinking down and down till it is either absorbed by the soil through which it passes, or accumulates at some greater or less depth below. But when the sun shines out again, or a dry wind blows, the moisture of the surface is evaporated, the upper soil grows dry again, and, the moment it is drier than the soil below, the damp soil begins to give up its moisture to this drier bed immediately above it. Thus the stream of moisture at once begins to ascend, and will continue to ascend until the surface is wetted again; it moves, in fact, either up or down, to the drier parts of the soil, whichever these may be, the movement being exactly like that of the oil in the wick of a lamp; 
as fast as the oil is consumed, more rises to take its place.

In time of drought the soil may appear quite dry even to some depth, but, as we have seen in the case of the tobacco planted in sand, plants can continue to draw moisture from the soil long after all trace of moisture has vanished, so far as can be seen. To find it at all we should have to dry the soil by artificial heat; but it is there, and the plant manages to draw it out.

In very long droughts, even the springs near the surface may fail, all their water being drawn away from them by degrees.; but still, at a greater or less depth, some water there is, for the deeper wells do not fail though the shallow ones may; and, unless this water be buried under some bed through which it cannot pass, it will continue to rise to the surface.

The water which plants need, therefore, for growth, and to supply the small loss by evaporation and the large loss by transpiration, comes to them from rain and dew; it is also very largely absorbed from the air by the soil; and the large stores accumulated in the ground are also drawn upwards as they are neededchiefly, of course, during the spring and summer. In autumn, when growth ceases, transpiration is less; in winter, when the trees are bare, there is next to none, so that they have little need of water. In spring and summer, on the other hand, they need much, and receive it, in part, from the accumulated stores of the other months.

All the water which plants transpire-in many cases a very large quantity, as we have seen-is taken up by 
their roots, and their roots alone. And these roots we must now look at a little more closely.

A root is a very wonderful organ, much more wonderful than a passing glance would lead one to suppose. And, indeed, the most important parts cannot even be seen, without careful examination.

The root serves two purposes : it keeps the plant in one place, enabling it to stand against the wind ; and it collects from the soil food and water which the plant can obtain in no other way, and without which it can neither grow nor exist.

Some plants have a single fleshy root, like that of a carrot, which descends straight into the earth, and has no branches, but only a few fibres growing from it. A carrot needs a good pull to uproot it; but an onion is easily lifted from the earth, as its roots are only fibres growing from the base of the bulb; while a dock may resist the full strength of a man.

Water-plants have few roots, as their food comes to them already prepared, without their having to search for it; bog-plants have more roots, as they have more work to do; and land-plants have most of all, as their roots frequently have to explore the earth for a considerable distance in search of food.

In a fertile soil, where there is plenty of food, roots are generally short and much branched. They branch out, in fact, where the food is to be found. But in a poor soil they have to go further to find what they need, and are usually long and slender.

But the mere mention of so many feet gives no idea at all of the real length of a plant's roots; for besides the long main roots, there are rootlets innumerable branching from them, and these rootlets, though they 
may be mere threads themselves, are covered with millions of hairs, generally so minute as to be hardly visible without the help of a microscope.

But here again, as we have seen in various ways before, it is the small, insignificant workers which are of the most importance. It is through the younger, threadlike rootlets, and through these millions of minute hairs, that food is chiefly taken up; and this is why, in moving a plant, the gardener is careful to keep a ball of earth round its roots, that the small, delicate rootlets may not be injured, and its food-supply lessened.

The root-hairs are being constantly produced in fresh millions, for each individual lasts but a few days.

It is difficult in any degree to realize what length of root a plant possesses, for to do this one must measure not only the main root, or roots, but the branches, rootlets and fibres as well; and even then, the fringe of hairs will have to be left altogether unreckoned.

An oat or barley plant, for instance, has roots several feet long; but when we say several feet, we merely mean that they stretch several feet downwards through the soil. Their real length, if the many roots are measured end to end, branches and all, is a very different matter. A barley-plant grown in a very small quantity of rich porous soil, was found to have a total length of root of 128 feet! This measurement included the fibres, but not the hairs. In loose soil, such as this, roots can make their way easily; but in closer soil, growth is more difficult, and so slower, and a plant grown in soil of the latter sort had roots only 80 feet long. Only 80 feet; but both the 80 feet and the 128 feet were packed 
into the fortieth part of a cubic foot of soil, a quantity which would be contained in a box between three and four inches square and equally deep.

Of course, if these roots had had their liberty they would have been much less branched, and would have spread much further. They would, so to say, have gone much further ahead, without running up so many by-paths. But being prisoners, they had to make the most of what they had, and so explored most thoroughly the small space at their command. Everyone knows what a mat of roots and fibres there will be when a plant is taken out of a pot too small for it; such a mat that the earth is often completely enveloped.

Now, of course, it is not natural for a plant to grow in a confined space, with its roots crowded together in this way, and when left to grow as it likes, in the open ground, its roots often roam to great distances, and therefore require much more soil than they make use of as food. The poorer the soil the farther the roots spread in their endeavour to find nourishment, and a maize-plant in sandy soil will send its roots out a distance of ten or fifteen feet.

It is supposed that only a very small portion, perhaps a hundredth part, of the soil helps to feed the plants growing in it. And this is probable enough when we consider it; for the soil, however fine, still consists of solid particles, which the roots cannot swallow; and though it is being constantly dissolved by water and gases, the process is a slow one. Where the soil is coarse the process is slower still. For, as a lump of sugar takes much longer to dissolve than the same quantity of sugar when reduced to powder, just so it is with the soil; when it is fine the water has a very 


\section{Roots}

much larger surface to act upon, and, can act more quickly. And this is one reason why finely-ground soils are so generally fertile.

But this is not the only reason ; for, besides drinking in the moisture of the soil, with whatever may be dissolved in it, the roots do much dissolving on their own account. And it is for this purpose, apparently, that all, down to the smallest fibre, and even hair, are more or less acid.

What food comes to them ready dissolved may be brought from a distance from the soil above or below the roots, but it is brought. The particles of soil, on the other hand, do not move, and the roots must go to them, and actually touch them, and that very closely, for the acid to be able to act upon them. A rich morsel which is a foot, or even an inch or a half-inch away, is of no use, except so far as it may be dissolved by water. The roots can do nothing with it unless some part of them, fibres or hairs, are near enough to get hold of it and press close to it, as the lichen adheres to the rock.

And it is this which makes it so important that a soil should be not only finely ground, but well mixed, so that all the ingredients may be within reach of the roots of each plant.

Most soils distinguished for their fertility contain a large proportion of fine matter, and to this is largely due the extraordinary productiveness of some of the lands of Ohio, which have borne heavy crops of wheat and maize for sixty years in succession. A considerable part of the soil here consists of particles which measure from the five-hundredth to the thousandth part of an inch across. The same thing is to be 
observed in the Black earth of Russia, and again in the mud brought down by the Nile and other rivers: all are distinguished for the fineness of their particles and their thorough mixture.

Why is it that a block of granite is able to support only a few lichens and mosses? Chiefly because it is a block, into which roots cannot penetrate. It would not make a really fertile soil even if it were crushed into coarse gravel, but it would grow more than it does now; and if it were ground to fine powder and kept well watered it would grow even corn-not perhaps good crops, though even granites differ in fertility, but still corn-whereas not a stalk can spring up while the granite remains a block, no matter how diligently it be watered.

By way of testing this point, an experiment was made with some barley sown in a soil consisting of pure felspar. Felspar is that one of the three minerals of which granite is composed, which, when finely powdered and washed away, forms beds of clay. In this case it was first only coarsely powdered, and the barley grew to a height of fifteen inches; moreover, the ears formed, one ear ripened, and two seeds were perfected. In the second instance the felspar was finely powdered, and the stalks were very much stronger. One grew to a height of twenty inches, and perfected four seeds.

Felspar alone, though a compound of several elements, could not in any case produce a good crop; for the stiffest clay soils under cultivation have been not only well ground, whether by ice or water, but also mixed besides, and contain sand and other ingredients. 
It is, of course, possible for the soil particles to be too fine, as they are in pure clay, which is so close in texture as to exclude what is as necessary to the plant as food and water, namely, air. A plant's roots need air as much as any other part of it, for they are constantly taking up oxygen, and hence all specially fertile soils contain a large proportion of sand, which makes them light and porous; for, though fine, it is not nearly as fine as the particles composing the clay, and does not turn into a stiff paste when mixed with water.

In a stiff, heavy soil roots make their way with less ease and with less rapidity than in a light, loamy one containing a large proportion of sand, and therefore they must needs collect food less rapidly. Moreover, both air and water penetrate a heavy soil less easily than they do a light one, and hence not only is the air which the roots need less able to reach them, but less water can enter also, and consequently less soil is dissolved and made ready for their use. The 'loamy soil' which a farmer loves contains from forty to seventy per cent. of sand.

Here, again, we see the great usefulness of earthworms. In sand they, like the roots, can make their way so easily that they have little need to remove the soil by swallowing it, the only means at their disposal. But in a stiffer soil they are obliged to do this, and thus they let in both air and water, to the great advantage of the plants, while they also spare the roots much labour by preparing for them airy passages, down which they can run with ease.

But though roots take advantage of these readymade channels, and are evidently all the better for them, they do not let go their hold on the soil, 
but keep a close grasp of it, lining the wormburrows with thread-like fibres, which cling fast to the sides. '

Roots coming in contact with a piece of limestone will leave upon it a perfect impression of themselves, even to the hairs with which they are fringed, showing how, like the lichens, they have eaten their way into the solid substance.

How do they do it? We can hardly do more than conjecture; but it seems probable that the acid in the roots acts much as acid contained in a bladder would. If a glass tube is filled with water made slightly acid with vinegar, and then covered with a piece of moistened bladder strained tightly over the mouth, and in contact with the liquid, this will represent the root, though the resemblance would, of course, be closer if the tube itself were of bladder. This, however, seems to be the only practicable way of trying the experiment. The acid is very weak, as the acid in the roots is weak; but if salts, such as phosphate of lime, and others found in the soil, are now strewn upon the bladder, they will in a short time begin to pass through it into the tube, being dissolved by the weak acid in its pores.

The acid in the roots acts, it is supposed, in a similar way, and thus the dissolved minerals are sucked in. But, as before said, living things have more power than dead ones; so it may well be that roots, like lichens, dissolve more than the weak acid alone would do.

The roots take up what they themselves dissolve from the particles of soil immediately surrounding and closely touching them, and also what the water in the 
soil has dissolved for them, with the help of carbondioxide and other gases.

The water thus taken up-for what is dissolved by the roots and what is dissolved by water and gas are taken up together-the water thus taken up is a very weak solution of various salts-phosphates, and others - so weak that it may fairly be compared with ordinary drinking-water.

No water in nature is or can be perfectly pure, as has been said, because it is constantly dissolving something wherever it goes. And though, even with what the roots have dissolved, the solution is still so weak as to pass for ordinary water, yet it must be borne in mind that the roots are constantly sucking it in, and that the leaves are as constantly returning the water to the air-only the water, however. The salts remain behind and accumulate day by.day.

The same sort of thing on a vast scale goes on with the rivers and the ocean. River-water is generally tasteless, though it, too, contains various salts dissolved in it. This small proportion of salts is, however, being constantly poured into the ocean, while the sun is constantly taking away by evaporation almost pure water. The salts, therefore, accumulate, and seawater is salt and bitter in consequence.

The salts left in a plant do not usually make it salt or bitter, because the quantity is altogether extremely minute in proportion to the plant's size; and as they are distributed through the whole of its substance, there is a continual demand for them while the plant is growing or putting forth fresh leaves.

But if a plant is stunted by drought it may become actually bitter A cabbage, for instance, which has 
not reached perhaps a quarter its proper size for want of water, will be quite bitter; and the reason seems to be that the salts, which would have been enough for a large cabbage, are compressed into a very small one. Or, in other words, the roots have not been able to find enough -water to dilute the food which they have gathered, as well as to keep pace with the transpiration of the leaves, and to allow of their proper growth. 


\section{XI.}

FOOD FROM THE SOIL

IT is but a very small part of their food after all which plants, generally speaking, draw from the mineral matter of the soil in which they grow; and yet this small quantity is not merely important, but absolutely necessary. It is dissolved by water and gases, and by the action of the plant itself, and is then taken up by the roots, especially the younger, finer roots, and roothairs, by which it is passed on to the stem, and so is conveyed to every part, not only to branches, leaves, and buds, but also to flowers and fruit. Every part of a plant needs some amount of mineral matter, and the plant cannot obtain it without water, for whether dissolved by the plant's roots or otherwise, it is in each case taken up in a very diluted condition; so diluted, indeed, that the water containing it is hardly to be distinguished from ordinary drinking-water.

The plant could not be sufficiently nourished by these very weak dilutions, especially while it is growing, but for the fact that it is constantly receiving them.

Perhaps one of the most striking examples of the way in which plants are fed by this very weak food is to be found among the sea-weeds. Many sea-weeds contain 
large quantities of iodine, which, like the rest of their food, they draw from the sea. With the smell of iodine we are all no doubt familiar; but if we mix one part of iodine with 300,000 parts of water we entirely lose it. That is to say, no one of our senses is keen enough to detect it. We can neither see, nor taste, nor smell it. But of course it is there, and we can find it again by adding starch, which is turned to a brilliant blue by coming in contact with even this minute quantity.

But the iodine contained in sea-water is less even than this-it is less even than the hundredth part of this infinitesimal amount. And yet the sea-weed manages to extract it. And although plants take their mineral food in such weak dilutions that we cannot detect its presence either by taste or smell, and might be inclined to think that it can matter very little what it is, yet they are discriminating; and their roots have to some extent the power of choosing what they will, or will not, take up.

This is evident from the fact that plants growing side by side will take up different food, or take it in very different proportions.

There is, for instance, the common reed and the common species of moss, which both grow in bogs. The soil is dissolved by water and gases equally for both, and both take up a good deal of dissolved flint, or silica; but the reed takes up also a very small quantity of salt, a little more, but still a very small quantity, of iron, no soda, a little magnesia, and a great deal of phosphoric acid; whereas the moss, which grows close by, takes very little either of phosphoric acid, magnesia or salt, but some soda, and much iron 
The same thing is also true of the farmer's crops, and it is for this reason that he varies them, not growing the same crop year after year, or even two years running, on the same soil, lest it should be exhausted and unable to feed them.

Corn-crops, for instance, take up much flint, which goes chiefly to give the hard, glossy coating to their stems; and they want from a fifth to a tenth part as much potash. Turnips and beet, on the other hand, take in little flint, but more lime and potash; and turnips and carrots will use up the sulphuric acid; while clovers want little sulphuric acid, but much potash, lime and soda.

All plants need more or less of several mineral substances, and even when it is 'less,' they cannot do without this lesser quantity, be it never so small. When, therefore, we say that corn-crops take up much silica or flint, it is not at all meant that they do not take some proportion of lime, potash, soda, sulphur, iron and phosphoric acid as well; for they use them all, in larger or smaller quantities.

The amount taken up of each varies in different kinds of corn; wheat, oats, barley, etc., have all their special needs, and so, too; have different varieties of the same kind of corn. More than this, different plants of the same variety differ slightly in this respect, as if they had their own individual preferences; but the difference is very slight, and in plants of the same species, the proportion always remains nearly the same.

And this is true, no matter where the plant may grow. If it grows at all, its ash-that is, the mineral substances which it has taken from the soil-will always 
be found to be pretty nearly the same; the proportion will be the same, that is to say, for of course, in unfavourable soil, the plant may be a dwarf. Grasses, for instance, which are like corn in taking in considerable quantities of silica, will take up just as much of this when they grow on the chalk soil of the downs as when they grow in a soil containing much sand. Yet chalk, pure chalk, does not contain a particle of silica.

As before remarked, however, such a thing as a perfectly unmixed soil is hardly to be found anywhere. Even on the mountains there is rarely less than ten per cent. of soil which has been brought from elsewhere, either by wind or water, or added to it by animals. So it is on the downs, and the grass finds there what it needs.

It would be rash to say of any plant that it will not grow on any soil until it has been tried; but plants certainly have their likes and dislikes in this matter, though sometimes a good climate will make up for poor soil.

Clover, for instance, loves lime; and cowslips and primroses are poor and scanty where lime is deficient, and luxuriant on chalk; but the heather, in this country at all events, shuns lime; and though it may be found growing close by on a patch of sand, and though its seeds must be scattered all around, it is not to be found on the chalk downs. Here and there a stray plant may be seen growing in a mixture of sand and chalk; but as a rule it is conspicuously absent from chalk and limestone in England, and in Wurtemberg it actually disappears even from sandy soils, if marl containing more than a fifth part of lime be added to them. But the same thing does not hold good in 
France, where heather is sometimes to be seen actually thriving on a limy soil.

Some plants have such peculiar tastes, or requirements, in respect of soils, that they must seldom, one would think, be able to gratify them; and one almost wonders where the seeds come from when the opportunity for growing does arrive.

Some, for instance, are never to be seen except after forest-fires; apparently because they require woodashes to grow in. Other plants have similar likings; and it was observed that after the fires of London and Copenhagen, plants of the same kinds grew among the ruins of both cities.

It is very remarkable, too, what slight, and even imperceptible, differences in the soil will make very great differences in the crops grown upon them. This is especially noticeable in the case of vines. Tokay wine, for instance, cannot be made except from grapes grown in the one district from which it takes its name. The vines may be grown elsewhere, but the wine is different. So, too, in France; vineyards growing side by side, and separated only by a narrow footpath, having the same aspect, and apparently the same soil, and cultivated in precisely the same way, yet produce wine of quite different qualities and very different values.

Plants differ, too, extremely, among other things, as to the quantity of salt which they take up. To corn, and most other plants, any large quantity is absolutely fatal. Some, however, take up much.

On the west coast of France grow various species of the small plants called, from their love of salt, saltworts, which are interesting because, though they are 
entirely lostsight of as one moves inland, and are not to be seen anywhere, all across Europe, except in the neighbourhood of salt-springs, yet they do reappear in some parts of Hungary, and in the great plains, or steppes, of south-east Russia, where the soil contains so much salt as to be often encrusted with it in summer.

Here these plants thrive as well as on the coast, but nothing else will grow, except a few such plants as are nearly related to them; and in some places it is the custom to cut and remove the whole crop of these every year, by way of improving the soil. The plants have some value in themselves, because they yield soda - common salt being a compound of soda; but the main object in cutting them is that, by this means, the salt may be gradually removed from the soil, so that other and more useful crops can be grown in it.

And what is true of the saltworts is true of every crop. That is to say, every crop takes away from the soil, not one mineral substance only, but several, in larger or smaller proportions; and the soil is to this extent poorer than it was before. If the crop is cut and carried, nearly the whole of what it has taken up is lost to the soil; in the case of turnips and other root-crops, the whole plant is taken away, and the loss is so much the greater.

A meadow which is mown by a machine, too, loses more than one mown with the scythe, as the machine cuts closer; and horses are said to take more from a meadow than either sheep or cows, ior a similar reason, because they are closer feeders. But where a crop is consumed by animals, it is not all lost to the soil. On the contrary, so much is returned to it in their 
droppings, and returned, too, with increased fertilizing powers, that the land is actually benefited, and needs no other manure; whereas hay-meadows cannot go on bearing crops year after year without being manured or top-dressed, to make up for their yearly loss.

It is a different matter, of course, where the crops grown by nature are concerned; for these, being neither machine-mown nor scythe-mown, so far from rendering the soil poorer, really do much to enrich it.

Herds of wild cattle may eat off grass and herbage, as they did for ages before man came and took possession of their grazing grounds, but they manured the soil in return. And the same is true, in its degree, of squirrels, monkeys, birds, bats-in fact, of all the grain, fruit, and vegetable eaters.

The same is also true, though in a different way, of the plants themselves. If they are left alone, they return to the soil all that they have taken from it, and more besides. For they give to it, also, that food which they draw from the air, of which we have yet to speak.

The roots of a tree are constantly bringing up supplies from the deep subsoil, which, when the leaves fall, are added to the surface-soil ; and the ancient forests of North America, after flourishing for ages, and producing enormous quantities of timber, left the soil, not impoverished, but so rich that it was hardly exhausted by a whole century of wasteful farming.

The 'yellow earth' of China, a deposit of very great extent, is believed to consist very largely of the ashes of plants, accumulated during more generations than one can attempt to realize, for in some parts it is more than $I, 500$ feet thick. 
It is the long-continued course of this green-manuring which has so largely contributed to produce the extraordinary fertility of the 'Black earth' of Russia and the region of Manitoba. And so, too, with the Pampas of South America, a still more interesting example, because the process is going on under our eyes.

In the winter Captain Head found the 'thistle' part of this region looking something like a rough turnipfield intermixed with clover, so large and luxuriant were the leaves of the 'thistles'-really wild artichokes. In the spring, the 'thistle'-leaves had spread, and had overgrown the clover, but still had the appearance of a rough crop of turnips. Less than a month later, however, they had shot up in the most surprising manner, and were in full bloom. They were now ten or eleven feet high, and formed such a close, impenetrable barrier on each side of the track that nothing whatever could be seen in any direction. The growth was so amazingly rapid that an army might easily have been hemmed in unawares by the thick, strong stems.

Before the end of the summer there was another change. The heads drooped, the leaves faded, the stems turned black and rattled in the breeze until they were blown down by the periodical hurricane, when they quickly rotted away, and the strong luxuriant clover rushed up again.

The artichoke, as well as its near relation the true thistle, requires a rich soil, and would be an exhausting crop if it were cut and removed, because it takes so much food; but as the roots penetrate to a great depth, it benefits the clover, and the clover in its turn enriches the soil for the thistles.

Clover is found, indeed, to be such a beneficial crop 
that farmers in America sometimes grow it in alternate rows with wheat, and this is also the only kind of green-manuring commonly practised in England. It is in warm countries, where growth is rapid, that this sort of manuring is chiefly useful; and in the Azores, yellow lupins are very frequently sown among the corn and ploughed in when it is reaped.

Lupins are plants which are especially active in dissolving mineral matter; and the same is true of other members of the large family of leguminous plants to which they belong-clovers, vetches, beans, peas. Moreover, not only these but other plants dissolve more food than they need for their own immediate use and leave it in the soil, making it easier therefore for their successors to find nourishment.

This, then, is another important service rendered by the wild crops which have grown for ages past on what are now the best soils in the world for the farmer's purposes. Whether these crops be trees, or shrubs, or herbage, they have not only brought subsoil up to the surface, but they have, at least in some cases, dissolved more than they have used, and have left it all ready for the crops which follow to make use of.

But even this is far from exhausting their very important list of services. Indeed, the most important of all has yet to be mentioned.

Animals cannot live either upon mineral matter or upon gases, though they need both, until these have been made ready for them, which they must be in the first instance by vegetables.

Plants are more independent, for they can make use 
of mineral matter, and of gases; but they, too, need a little organic matter as well, either animal or vegetable. Some plants need more than others; but no soil is really fertile which does not contain at least some small amount. As has been shown, however, no soil is absolutely lacking in this important ingredient, for wherever plants have grown, or animals, however lowly, have lived, there they have left their remains.

Why plants should need organic matter is another and more difficult question, which seems to be at present unanswerable. All organic remains, of course, contain some mineral matter; but this the plant can get from the soil. They all also contain much carbon; but this the plant can get without their help from the air. And finally, they all contain nitrogen in some one or more of its compounds; and it is this nitrogen which the plant wants, and cannot apparently get, in sufficient quantity, except from organic matter.

There is an abundant supply of nitrogen in the air, however, and why plants cannot help themselves to it - when they can, and do, take up carbon dioxide from the same source-one cannot say; but such is the fact. Both are gases; and, as nearly four-fifths of the air consists of nitrogen, there is certainly no lack of it. However, the plant takes the one up by its leaves, as will be seen in the following chapter; and does not take the other, much as it wants it.

All animal and vegetable matter, then, contains nitrogen; and as all plants, whether lichens and mosses, or oaks and palms, must have some amount of it, they most of them get it from this source-the decayed organic matter in the soil.

But there are others which get it equally well from 


\section{Food from the Soil}

living matter. The mistletoe and other similar plants get this, as well as other food, from the living trees or plants upon which they grow. And other plants, again, sometimes turn the tables on the animal world, and actually devour living insects.

The plant called Venus' Fly-trap is one of these insect-eaters, and a very curious plant it is. Its leaves end in two lobes, on each of which are three delicate hairs, so placed as to form a triangle, and in such a position that it is almost impossible for any insect alighting upon the leaf to help touching them. As long as the leaf only is touched, no harm is done, but if but the tip of one of these magic hairs be touched, the leaf closes instantly upon the victim, and does not re-open until it has sucked it dry! The trap will close equally upon a dead, dry fly, or any other substance placed upon it, but it re-opens almost immediately, when the plant, by some mysterious instinct, discovers that the morsel is indigestible.

A large blue-bottle will be seized at once, and squeezed so tight that escape is impossible. But a meal of this sort seems to be very satisfying, for in one instance the leaf did not open again for twenty-four days, and when it did, though the dry remains of the fly were removed, no attempt to catch more was made until several days later. There was a similar result in the case of caterpillars, raw meat, and spiders. All are digested by means of an acid which the leaf pours out upon them.

It is a curious fact, that the dropping of water upon the trap does not make it close, unless the sun is shining, or has been shining immediately before, upon it. In this case, the plant, not being prepared for rain, 
seems to be for the moment deceived. Rain usually comes when the sky is cloudy, and then the leaf, knowing apparently what to expect, takes no notice. If it closed for rain, it would of course often lose a meal.

One of these plants, having six leaves, has been known to comfortably digest twelve flies, or twelve good-sized spiders, at once, one for each lobe, after which it was satisfied for some time.

Venus' Fly-trap is found only in Carolina; but we have carnivorous plants in England, and it seems very possible that many plants, hitherto unsuspected of it, feed upon insects when they have the opportunity.

The Sundews, British plants nearly related to the Fly-trap, openly catch prey, and are frequently disfigured by the remains of insects. Their leaves are fringed, as well as scattered over, with red hairs. Each hair has a shining drop on its tip, which, lovely and innocent as it looks, serves only to entrap the insect touching it. Dragon-flies seem to be attracted and fascinated by these glistening beads, for they have been observed to hover over the leaf, and then to dart down upon it and be hopelessly caught by the folding of the tentacles. In the small space of one square foot, six Sundews have been seen growing at once, every one of which had secured a dragon-fly, while one had even caught two. The plants were young, and the leaves in some cases were smaller than the prey, whose wings were two inches across, while their bodies were an inch and a half long; but chance of escape there seemed to be none for them.

The Bladderwort has been seen to catch newlyhatched roaeb and also worms, by means of its 


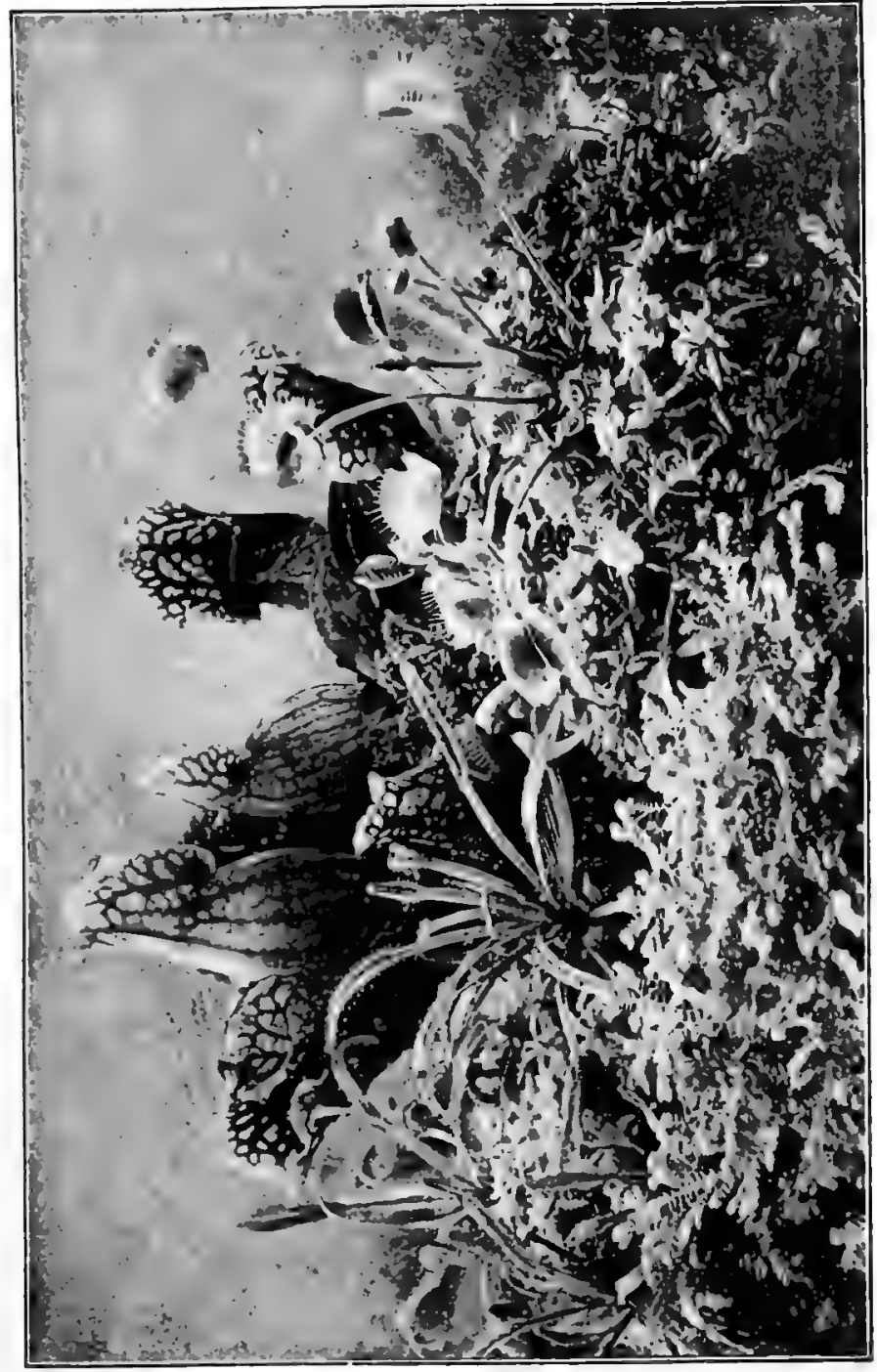



bladders; and the Butterwort catches its victims by means of the sticky glands with which its leaves are thickly covered, rolling up its edges over them and undoubtedly eating them.

The various Pitcher-plants also feed upon the large number of insects drowned in their receptacles, which are from two or three to as much as eighteen inches deep, and always contain water.

But, whether or no many plants are actual flesheaters, it is certain that they all need nitrogen; and other food, however abundant, will not be enough for them, or enable them to grow properly, if they be stinted in this respect. Their more usual way of obtaining it, however, is from the soil, or from the air; but in neither case can they take the pure gas itself; it must be in the form of a compound before they can make any use of it.

By way of trying whether plants could do without nitrogen, other than that by which they are surrounded in the air, three pots were filled with a soil of sand and brick-dust, from which all animal and vegetable matter had been removed. A couple of sunflower-seeds were planted in each, and all three were watered with pure, distilled water, containing no food whatever.

The plants in the first pot turned out mere dwarfs, as was to be expected; those in the second were not much better, though they had had a small quantity of clover-ashes given them; but those in the third were almost as large as the finest specimens grown in the garden, for they had been supplied with a compound of nitrogen, in the form of potassium nitrate; and while the two first had managed to get only about the thirtieth part of a grain of nitrogen from the air, these 


\section{2}

had taken sixty-six times as much from the soil. The quantity is still very small, of course, only two grains and a fifth; but it strikingly illustrates the immense importance of small, and even minute quantities, since it made the whole difference in the growth of the plants.

The dwarf sunflowers obtained their small fraction of nitrogen from the air; but this is no contradiction to what has been previously said, for they did not take pure nitrogen, but ammonia, which is a compound of nitrogen and hydrogen.

There is always some very minute quantity of ammonia in the air-about one part in a million-and there seems to be no doubt that plants can and do take this up by their leaves, for they thrive all the better when the quantity is artificially increased. But they take it up also, and in larger quantities, by their roots, when it has been absorbed by the soil, or brought down to it by rain, snow, and dew.

The quantity of nitrogen thus washed down in combination with hydrogen in the course of the year seems to be from about $2 \mathrm{lb}$. to nearly $2 \mathrm{I} \mathrm{lb}$. per acre; but the average is about $4 \frac{1}{2} \mathrm{lb}$. to the acre$4 \frac{1}{2} \mathrm{lb}$. spread over an acre of ground! Considering that there are 7,000 grains in a pound, and that the sunflowers, even when they had more within reach, took up little more than a grain of nitrogen apiece, perhaps the quantity may not sound so very small.

But an acre of wheat, yielding twenty-eight bushels, takes up about $45 \frac{1}{2} \mathrm{lb}$. of nitrogen; while an acre of clover uses ro8 lb.!

And even this does not at all represent the whole of what is required; for the roots, however many, cannot 
possibly be in close contact with all parts of the soil at once, and they can no more make use of all the nitrogen than they can of all the mineral matter, or all the moisture; so that of this, as well as of the rest, they need much more than they can actually use.

An acre of soil, one foot deep, weighs some $4,000,000 \mathrm{lb}$; and just a few pounds of nitrogen equally mixed in this would be almost as difficult to find as a needle in a haystack; and even if there were actually as much as the crop required, the roots could not reach it.

A heavy wheat-crop needs, therefore, nearly $300 \mathrm{lbs}$. of nitrogen to the acre, or about six times as much as it actually takes up. And this it certainly cannot get from the ammonia in the air, or from that which is washed from it into the soil.

But when organic matter decays, whether it be animal or vegetable, the nitrogen contained in it combines with other gases to form not only ammonia, but also nitric acid.

Much of the ammonia streams off into the air, but the nitric acid remains and combines with potash, soda, lime, magnesia, or iron, with which it forms nitrates. These nitrates are easily dissolved, and it is from them that the plants obtain their nitric acidvery much diluted, of course, as is all the food which they take from the soil.

As already remarked, plants have the power of decomposing such salts, taking one ingredient and leaving the other. The sunflowers which throve so well in the experiment described, were supplied with potassium nitrate, and from this they were able to extract the nitric acid which they needed. 
Nitrates are very soluble, and in damp soil they are formed and dissolved so quickly as seldom to be visible. But it is not so in regions where rain falls either at certain seasons only, or very rarely. The most fertile soils of Bengal, for instance, are often covered during the dry season with a white crust of some of these salts, chiefly potassium nitrate, otherwise called nitre and saltpetre. The crust vanishes as soon as the rain comes, being dissolved and washed into the soil, which is so rich as to bear two or three crops a year.

Wherever these nitrates are formed, whether, as in England, they are dissolved almost at once, or whether, as in dry lands, they accumulate and encrust the soil, they are formed by the decay of animal and vegetable matter. And what, it may be asked, causes this decay? Not the action of the air ; for in perfectly pure air organic substances do not decay. The change is brought about by the action of living organisms, invisible, but very potent in their effects.

We have all heard enough about 'germs' of late to know that they swarm in the air; but they also swarm in all the moist places of the earth. Some few classes of them are dangerous to man, and produce diseases of various kinds; others are not only harmless, but productive of the greatest good.

All decay, fermentation, or putrefaction, whichever we call it, is their work; and when we say 'work,' all that is meant is their living, growing, multiplying, which they cannot do without feeding. There is an immense variety of them, and they produce different results according to their different modes of feeding. The yeast which' is put into dough, the 'mould' which 
grows upon paste, or jam, are all of similar nature, and all produce alterations in the substance which they attack. When we like the result of these alterations, we call the process 'fermentation'; and when we do not like it, we call it 'putrefaction'; but both are substantially the same, for both are the result of decomposition. Grape-juice, apple-juice, and wort, are converted by these 'ferments' into wine, cider, and beer respectively; and another ferment again alters wine yet further, and turns it into vinegar.

It is these living organisms which bring about all decay of animal or vegetable matter, whether in the soil or elsewhere.

Their work in the soil seems to go on chiefly in the upper nine inches, and most rapidly when the weather is warm and damp.

The multitudes of leaves drawn in by worms, the old roots of former crops, or green crops which have been grown only that they may be ploughed in-all are decayed, and so converted into food, of which the next crop can avail itself.

As has been more than once remarked, all soils contain more or less organic matter; but unless the amount is very large, as it is in the Russian Black earth region, Manitoba, and elsewhere, not much of the nitrates formed by its decay will be left in the upper twenty-seven inches of the soil after a crop of corn has been grown in it. Organic matter there will still be, but decay is gradual, and nitrates take time to form; so the farmer must supply the want in one way or other.

In former days, till within the last century in fact, his way of doing so was simple. He merely ploughed 
up the field, and let it alone to recover itself; in other words, he allowed it to lie fallow.

And what goes on in a fallow field? Generally speaking it is, or was, both ploughed and harrowed repeatedly, so that the soil might be exposed as much as possible to the action of the air and rain, by which the mineral matter would be dissolved ready for the next crop. Then in the winter the soil would be yet further broken up by the freezing of the moisture in its pores, which would separate grain from grain, reducing it to powder in a way that no plough or harrow yet invented can do. The crumbling of the soil would make it yet more easily dissolved by water, as well as more easy for roots to penetrate; nor must it by any means be forgotten that while the land lay idle the worms were busy, turning it over, also, grain by grain, and enriching it as already described. And though the farmer did not sow it, seeds were sown by the wind, and a crop of weeds was certain to spring up, whose half-decayed leaves the worms would drag into their burrows. The whole wild crop, too, would be ploughed in, and, with the roots of the farmer's last crop, would be gradually decayed. The soil when damp would absorb ammonia from the air, and ammonia would also be brought down by rain and snow, and converted into nitric acid, which would combine with some of the minerals already mentioned; and in this way, as well as by the decay of the organic matter left in, or added to, the soil, a fresh supply of nitrates would be prepared. 


\section{XII.}

\section{LEAVES AND THEIR WORK}

ALL the plant-food which we have yet considered is drawn from the soil, with the exception of- the minute quantity of ammonia taken in by the leaves from the air. But this latter is far from being all that the leaves contribute to the food-supply.

The roots furnish food from the soil-mineral and organic matter; and the leaves furnish food from the air-the carbon, which makes up about half the dry weight of a plant-half its weight, that is, when all the water has been removed from it. Roots and leaves, therefore, supply about an equal amount of food.

But the leaves do more than merely supply food; they prepare it for the whole plant, both that which they themselves take up, and that which is procured by the roots. Leaves are the food-manufacturers; and it is they which combine the various materials, and distribute food to the several parts.

Nitrogen, the food derived from organic matter, which we have last considered, is needed in some combination or other by all parts of a plant, but especially by the seed. No one needs to be told that grain is more nourishing than straw; but the 
reason why it is more nourishing is that it contains more nitrogen, in the form of nitrogenous or albuminous compounds, commonly called albuminoids, because they resemble the albumin, or white, of an egg. There is albumin in the liquid part of blood, and there is albumin in the seeds and juices of plants. "There is fibrin in flesh and in the thick red part of blood; and there is vegetable fibrin, a sticky substance usually called gluten, in flour. There is casein in milk and cheese, and there is casein in beans.

These various substances are all jelly-like, and are very similar in composition, whether they are obtained from animal or from vegetable matter. They are called nitrogenous because it is the nitrogen they contain which gives them their especial characteristics and value as food; but the nitrogen in them forms less than a seventh part of their substance, more than half of which consists of carbon. In addition to this large amount of carbon, most of the nitrogenous compounds contain sulphur, besides hydrogen and oxygen, and most of them phosphorus as well. They could not therefore be formed without the help of mineral matter from the soil, and of carbon from the air ; the nitrogen being obtained both from the nitrates in the soil and from the ammonia in the air.

All the corn crops, as well as the clovers, beans, peas, and other leguminous plants, require much nitrogen, especially when their seeds are forming and ripening; but by the time they have done blossoming, they have taken up all they want, and it is being prepared and compounded by the leaves, to be gradually passed on by them to the growing seeds as they need It. Grass, therefore, is not cut for hay until after it 
has blossomed, because it then contains most nitrogen and is most nutritious. For the nitrogenous compounds are the flesh-forming part of all food, animal or vegetable.

They are very much alike in composition, as has been said, and substances which are closely similar may be obtained both from a beef-steak and a cauliflower; from the white of an egg and from a cabbage; from milk curd, and from peas and beans, of which the Chinese do actually make a vegetable cheese.

Quantity for quantity, a cabbage is, indeed, less nutritious than the white of an egg; but the cabbage contains a similar substance. It would, however, be necessary to eat a much larger weight of cabbage to obtain as much flesh-forming food as is contained in an egg.

And then, again, though the nitrogenous compounds obtained from flesh and vegetables are similar-so closely similar even as to appear almost identical-they are not absolutely identical, and it would be rash, therefore, to conclude that they are equally nutritious. For, if one thing be more plain than another, from what has been said in the previous pages, it is the immense importance belonging to little things-to trifles so minute as almost, or quite, to escape detection.

Let us remember the vineyards growing side by side -the treatment the same, the soil so apparently the same, that the difference cannot be detected-and yet the wine from the one is worth, and fetches in the market, twenty times as much as the other! The vines being of the same species, and all other things being equally enjoyed by both, it follows that the difference 
in quality must be caused by some slight difference in the soil, which is so slight as to be undiscoverable.

If, therefore, so slight a difference in the vine's food can make so large a difference in its produce, it seems altogether rash to conclude that the cheese of beans is as nutritious as the cheese of milk; or that it makes no difference whether one dines on cauliflower or beef.

All plants do not contain an equal amount of the nitrogenous compounds; and even the same plant contains very different quantities in different parts, and also at different stages in its life.

Leaves and stalks are less nutritious than seed, and the seed itself is most nutritious when it is ripe, as it is then that it contains the largest amount of nitrogen. Ripe ears of maize, for instance, contain ten times as much nitrogen as green ears; but even then they contain less than either rye, oats or wheat, and less than half the amount contained in peas, beans, or lentils. Lentils, indeed, are among the most valuable of the seeds used as food, for nearly a fourth part of their substance consists of albuminous, or nitrogenous, compounds. As for potatoes, they are very low down in the scale of food, for they are chiefly water, and the amount of flesh-forming food which they yield is only two parts in a hundred, less, that is, than meadow-grass before it has blossomed.

We must now look a little more closely at the work done by the leaves, for it is they, as has been said, which supply the plant with carbon. Carbon is wanted for the nitrogenous compounds; carbon is wanted for the plant's skeleton, and for its wood; carbon is wanted for the manufacture also of starch, gum, sugar, oils, acids, and the various aromatic 
compounds to which plants and flowers owe their fragrance.

And this carbon the leaves have no difficulty in providing, so long as the roots do their part; but if they fail, the leaves must fail too. For the plant is a whole, a body, of which every part is dependent upon the rest. But while the roots can do their work in the dark, the leaves are perfectly helpless without light.

Give the plant light, however, together with the proper food which the roots collect from the soil, and then the leaves have no difficulty in adding the carbon which is their share.

And why, it may be asked, should they have any difficulty? Since the whole plant wants it, and has to get it through the leaves, surely it would be more strange if the leaves could not find it, since they live in the air, where it is.

Perhaps; but the proportion in the air is extremely small, though the amount sounds large; and leaves cannot wander in search of food, as roots do. The food must come to them, as they cannot go to the food. Carbon exists in the air, combined with oxygen, as the gas carbon-dioxide, or carbonic acid; and there are about three billion four hundred million tons of the gas in the atmosphere of the whole globe. The figures convey little to one's mind, but, at all events, the amount sounds comfortably large-sufficient, at least, to preserve the vegetable world from all risk of a dearth of this species of food.

And yet it has been calculated that, if used at the present rate, the whole of this enormous supply would be exhausted in about a hundred years, after which 
not so much as a blade of grass could exist until the supply were renewed.

Let us put it in another way. The amount is large in itself, but it is enormously diluted--so much diluted, indeed, as to be hardly reckoned at all! That is, in speaking of the air, we commonly say that it consists of about four-fifths nitrogen and one-fifth oxygen, leaving the carbon-dioxide out of the account altogether. For, except in confined spaces, and under special circumstances, one part in twenty-five thousand is all the carbon-dioxide that the air contains, so vast is the space through which the gas is distributed. There is just enough carbon-dioxide in the air to furnish twenty-eight tons to every acre all over the globe-twenty-eight tons of gas, or eight tons of carbon!

But an acre of beech-forest would use up the whole of this allowance in about eight years; and it would not last an acre of bananas much more than one year.

All plants do not, it is true, use up carbon at these rates; but it is evident that the supply needs pretty constant renewing. And it is renewed day by day, hour by hour; nor, so long as animals breathe, and fires burn, and vegetable matter decays, is there any danger that the supply will run short.

Whenever carbon unites with oxygen it is what we call burnt, and carbon-dioxide is produced. The carbon disappears, but it is not destroyed-it has only been made invisible by combining with oxygen. Whenever, therefore, animal or vegetable matter decays, the carbon which it contains is slowly burnt, and the gas passes off into the air as it forms, unless prevented, as it is, in a great measure, when produced underground. 
Again, when animals or plants breathe, the oxygen which they inhale unites with, and burns, part of the carbon of their food, and the gas is breathed back into the air. The air we inhale contains but one part in twenty-five thousand of carbon-dioxide; but the air we exhale contains much more-from three to six per cent. Plants, however, breathe very much more slowly than any warm-blooded animals, and give off less carbon-dioxide in proportion.

Whenever carbon is burnt by combining with oxygen, whether in food, coal, wood, gas, oil, candle, or in decaying vegetable-matter, there carbon-dioxide is formed. It is being constantly poured into the air, therefore, by men and animals, by the chimneys of factories and houses, by volcanoes, and by the soil.

But it is not produced in anything like equal quantities in all parts of the world. Very little is returned to the air above the ocean, and that little chiefly by passing vessels; and as there is more ocean than land in the southern hemisphere, much less is produced there than in the northern hemisphere, which is chiefly land.

Then, again, the eastern hemisphere is much more densely populated than the western, besides having, of course, many more factories, furnaces, and engines of all sorts, which are constantly burning carbon. It might seem not improbable, therefore, that some parts of the world, such as the islands of the Pacific, should be at times in danger of not having carbon-dioxide enough to supply the wants of their vegetation, especially when we consider that bananas, which need such large quantities, form an important item in their crops. 
But the fact is not so; for the supply is equally distributed. More fires are kept burning, and more carbon-dioxide is produced in winter, when the trees are leafless and do not want it, than in the summer, when they do. And yet we are not choked by it, or even inconvenienced by it, in the winter months, so it must be got rid of somehow. For, if there were two per cent. in the air, we should have severe headache, and ten per cent. would suffocate us. What, then, becomes of it? Roughly speaking, we may say that the carbon-dioxide produced during the winter of the north goes to feed the vegetation of the south-the thistles, clover and grass, for instance, of the Pampas, which are flourishing in all their luxuriance while winter prevails with us. And it goes, to some extent, at least, because the leaves of the southern hemisphere drave it thither.

The ocean of air which surrounds the world is not, it must be remembered, a compound, but a mixture. If we could see it we should find oxygen, nitrogen, carbon-dioxide, ammonia, all perfectly mixed, but perfectly distinct. The combination of two gases, oxygen and hydrogen, makes water-a liquid entirely different from both; but there is no such combination and alteration in the gases of the air. Each keeps its own character ; but, though all are of different weights, they are so thoroughly and perfectly mixed that, except under special circumstances, there is but little appreciable difference in the air of different parts of the world.

Carbon-dioxide is the heaviest of these gases, and it is more than twice the weight of the mixture of these gases which we call the air. Where it is poured out from cracks in the earth, as it is largely in some volcanic 
districts, its weight keeps it down for a time near the ground, but gradually, in obedience to a mysterious law, it rises and spreads through the air. Its weight draws it down to the earth, or, more correctly speaking, the earth attracts it to itself more than it attracts either oxygen or nitrogen. It is heavy, because the earth attracts it, just as a stone is heavier than a feather. But it rises.

We should be surprised to see a stone thrown from our hand continue to mount upwards instead of falling to the ground, but this is precisely what carbon-dioxide does, and we can but state the fact without explaining it. Gases, no matter what their weight, are obliged to mix one with the other.

Put into a bottle first some heavy carbon-dioxide, then some oxygen, which is lighter, nitrogen, which is lighter still, and, lastly, hydrogen, the lightest of all, which is so light that it has to be poured upwards, and, though at first the heaviest gas will be at the bottom, before long all will be perfectly mixed, and there will be as much hydrogen at the bottom as at the top. Carbon-dioxide moves more slowly than hydrogen, owing to its weight, but move upwards it will, and that without any shaking.

All, or part, of the carbon-dioxide might, however, be removed from this mixture without affecting the other gases, if a piece of caustic potash were introduced; for this substance has the power of attracting and absorbing this particular gas. Each of the other gases might also be removed by similar means, one by one substance, and another by another.

Leaves, then, act upon carbon-dioxide in some such way as caustic potash does. They attract it to them- 
selves and absorb it; but, by so doing, they are constantly diminishing the amount of the gas in the air immediately surrounding them; and as, according to the law of their being, gases must mix equally one with the other, more carbon-dioxide flows in to supply the place of that which is absorbed. Streams of the gas are therefore constantly flowing towards each leaf, even when the air is still; when there is wind the whole air is, of course, in motion.

We have now to see what becomes of the carbondioxide when the leaves have taken it up. As has been said, in most plants nearly one-half the dry substance left when the water is removed consists of carbon, of which charcoal is an impure form. Carbon enters into the composition of every animal and vegetable substance, no matter how minute. It is to be found in every part of a plant from the root upwards, but especially in the seed. In the grains which we use as food the quantity of carbon amounts to some forty or fifty per cent. of the whole; and, though the carbon compounds are not, like the nitrogenous compounds, flesh-formers, they are equally important as fat-formers, and as supplying fuel to maintain the heat of our bodies. The carbon of our food is oxidized, burnt, by the oxygen of the air we breathe; heat is thus produced, and the greater part of the carbon is given back to the air as carbon-dioxide.

One pound of wheat-flour contains about nine and a half ounces of starch, and starch is a compound of carbon, oxygen and hydrogen; but it also contains two ounces of gluten-one of the nitrogenous compoundsand half of this is carbon; and besides these it contains smaller quantities of sugar, gum and fat, and 
these are all carbon compounds; so that altogether the pound of flour contains some seven ounces of carbon.

Some of the palms, as the sago palm, use very large quantities of carbon in forming the starch of their pith: one tree, for instance, often yielding the extraordinary amount of $800 \mathrm{lbs}$. of starch. All the sugars, oils, gums, caoutchoucs, of the vegetable world, contain large quantities of carbon, and so also do the fibres of cottonl, flax, hemp and others.

But, as already said, carbon forms part of the

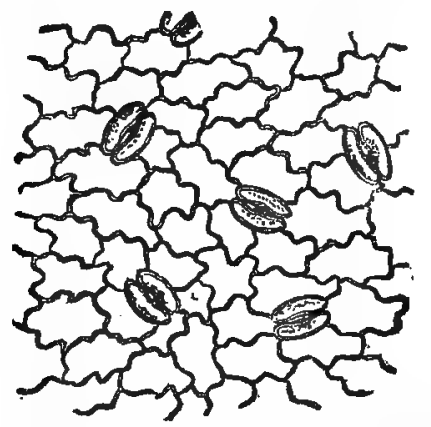

Surface leaf-cells, with pores, magnified.

structure of every portion of a plant from root to seed, and it enters largely into the composition of the skeleton, or frame-work, both of stems and leaves; for a plant's skeleton consists of fibre, identical in composition with the fibres of the cotton and other plants used for weaving purposes.

Now, both the skeleton and the flesh of a plant, every part of it, indeed-roots, stems, leaves, flowers, fruit, seed-consists either of a single cell, or of an assemblage of cells, which may be compared with the 
rells of a honeycomb, except that they vary extremely in size and shape.

Some cells are so minute as to be altogether invisible to the naked eye; as, for instance, the spores of lichens and fungi, the 'germs ' already mentioned, and certain minute water plants, each and all of which consist of a single cell, filled, like the honey-cells, with more or less fluid contents.

But the cells in the flesh of a lemon are gigantic by comparison, being half an inch long; the cells of

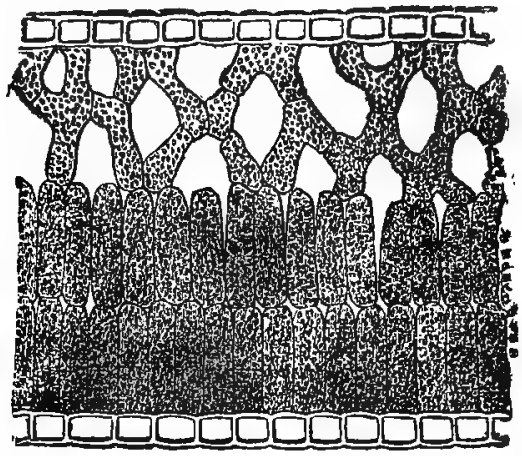

Transverse section of a leaf, magnified.

fibres are often much longer than this, and there are cells of all sizes between these, the most usual size being from $\frac{1}{1200}$ to $\frac{1}{200}$ of an inch across. Cells are of almost every possible shape, too-globular, square, six-sided, twelve-sided, or quite irregular, with their outlines bea utifully zigzagged or waved. But, whatever their shape and size, their walls, thick or thin, are composed of the skeleton material mentioned above, which is called after them ' cellulose.'

This material, like cotton and other fibres, is composed in great measure of carbon, and, as all plants in- 
crease in size by the multiplication of cells, it is evident that they could not grow at all in air containing no carbon-dioxide. Neither can they grow if deprived of their leaves, for these are the chief manufacturers of cellulose and other food. A tree stripped of even half its leaves will be unable to make much wood, though it may manage to live.

The skin of a leaf usually consists of a single layer of cells, not green, but colourless and transparent, and beneath these are other cells containing, besides other things, 'leaf-green,' or colouring matter. It is in these lower cells that the manufacture of the plant's food is carried on; and, though the process cannot be explained, one or two facts are certain-it cannot, in most plants, go on without light, or in any without the leaf-green.

The gases of the air are able to pass through the cell-walls, both in and out. It must not be forgotten that plants need air for breathing, as well as carbondioxide for food; and though they breathe as well as feed by means of their leaves, the two processes are quite distinct.

What the plant does with the carbon-dioxide is to separate the carbon and keep it, and to let go most of the oxygen. The two have to be torn asunder, and this is done in the cells containing leaf-green. But the leaf-green itself cannot be developed either without light, or without iron; and when developed it cannot act in darkness.

For the supply of iron the leaves are, of course, dependent upon the plant's roots, and if the roots cannot find it, the leaves and young stems remain yellow or colourless. Compounds of iron are, however, so 
very general in all the rocks composing the earth's crust, that it is almost impossible to find any soil quite without them.

But the iron may be taken away by artificial means, and when this is done the leaf-green turns yellow, as human beings do when their blood contains too few red particles, and for precisely the same reason. Both stand in need of iron. Iron oxide is reddish when it contains the full amount of oxygen possible, and green when it contains less. Give the plant iron and keep it in the light, and the grains of leafgreen at once begin to turn their proper colour, and tiny grains of starch form within them.

A very little light, barely enough to read by, will be sufficient to make a plant begin to turn green, but not sufficiently green to enable it to separate the carbon; and therefore in dim light no starch grains can be formed. In ordinary daylight, however, whether the sun be shining directly upon the plant or no, these starch-grains are being continually produced; but the brighter the light the more briskly the manufacture goes on, up to a certain point-provided, that is, that the air contains carbon-dioxide wherewith to furnish the necessary supply of carbon. If it does not, no starch, of course, can be formed, no matter how bright the light, or how green the leaf-green.

But all air, unless artificially deprived of it, contains enough to furnish what the plant requires in this respect, thanks to the supplies which are being constantly furnished to it. If the supply of carbon-dioxide were not renewed, however, it would be exhausted, as already mentioned, in about a hundred years by the present vegetation of the globe. But if the world were 
covered with beech-forest, all this gas, even though it amounts to billions of tons, would be gone in eight years! For one acre of beechwood takes about a ton of carbon every year; and to supply one ton of carbon, three and a half tons of carbon-dioxide gas are necessary. This is taken up not only by the leaves, but by all the green parts of a plant, leaves, buds, stems, and fruit, so long as these remain green; for it is only in the cells which contain leaf-green that starch is manufactured from the gas. These green cells lie immediately underneath the thicker-walled but transparent

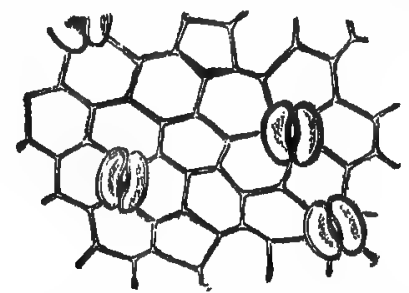

Surface leaf-cells, with pores, magnified.

cells of the surface which compose the skin; and through the skin the gas finds its way into them.

The leaf-pores, by which water escapes, are openings in the skin formed by two curved, lip-like cells, which gape open in hot, bright weather, and close more or less in rain, damp, and darkness ; and it is when they open most widely that the manufacture of food goes on most briskly. For it is then that most carbon is separated, and most food is pumped up from the roots, as that is the time when the plant transpires most, and in this way both kinds of food are received together. When there is much transpiration, and water containing dissolved food is pumped up rapidly, then also much carbon is received, and vice versâ. 
Such plants as the cactus, which have no leaves, very few pores, and skin so thick and leathery that evaporation is prevented, transpire very little, and grow in consequence very slowly. The tall Torch-thistle cactus of Mexico is said to take some hundreds of years in attaining its full size; whereas the thin-leaved gourd of the East is noted for its very rapid growth.

How the food from the soil and the food from the air are combined, and distributed from the leaves to all parts of the plant, is unknown; but from them each part does receive its due share of nourishment, one more of this sort, one more of that.

But without the leaves no food can be prepared, except where the stems take their place; and without light the leaves have no power to act. Hence the plant's whole life depends upon the sun.

In the autumn, when the plant has finished growing, no more leaf-green is formed, and the leaves begin to change colour; for instead of manufacturing food, they are giving up their own stock to feed the young fruit.

Some plants, such as lichens, copper-beeches, and others, might be supposed to possess no leaf-green, because it is not visible; but they have it all the same; it is merely concealed from view, hidden by other colouring matter.

But some plants never have any leaf-green under any circumstances, and, therefore, being non-manufacturers, they have to live by the labour of others. Among these are the fungi, which grow and feed entirely upon organic matter, animal or vegetable, and are independent of the light. Mushrooms, for instance, may be grown in cellars; toadstools spring up in the night; for their food of all kinds-mineral food, nitrogenous 
compounds, carbon compounds-has been made ready for them in the light, by the dead vegetable matter upon which they grow. Perhaps it is the fact of their not having any work to do which enables them to grow with such extraordinary rapidity, as they devote all their energies to feeding and increasing in size. The cells of the puff-ball, for instance, multiply at the rate of three or four hundred million in an hour, and the plant will attain the size of a large gourd in a few days. The curious brown Bird's-nest orchis is another plant which has no leaf-green, cannot provide its own food, and lives upon dead vegetable matter.

But there are other plants devoid of leaf-green, which prey, not on the dead, but on the living; sucking their juices, and profiting by their labours in earth and air. Among these may be mentioned the broom-rape, a brown, uncanny-looking plant, which attaches itself to the roots of living plants, clover and others, and draws all its nourishment from them.

In one way or another, then, all plants obtain carbon; and when they have to do it by their own exertions they must have leaf-green, and they cannot usually have leaf-green without light, or, in any case, without iron.

But, it may be said, seeds, most of them, begin to grow in darkness, underground, and so do bulbs; and they are usually pile yellow at first. If they have no leaf-green, as they evidently have not, then, if cells cannot be multiplied without carbon, and carbon they cannot get for want of this leaf-green, how do they manage to grow?

In the same way that other plants do which are also without leaf-green. They make use of the carbon stored 
by others. That is to say, they live for a time, seedlings - upon the material stored in their seeds-bulbs, upon the material stored in the bulbs, which are buds, not roots-all of which has been prepared by means of leafgreen, and in the light.

In the case of bulbs, the leaves go on collecting food long after the plants have-done flowering, in readiness for the blossoms of the next spring; and if the leaves are cut off before they have finished their work, the bulbs shrivel, and have not the means of supplying next year's blossoms at all. The autumn crocus comes up and blossoms, without its leaves, but it is dependent upon them for the means of putting forth its blossoms; for the leaves have been busy months before, in the spring, storing the necessary material in the bulbs.

Seedlings, in like manner, when first they germinate under the soil, before they are provided with leafgreen, live upon the food stored up within them; but if, when this is exhausted, they are still kept in darkness, they will not only remain yellow, but will lose, instead of gaining in weight, and that though their roots may be busy collecting food from the soil.

But why, it may be asked, should they lose in weight? Without carbon they cannot, of course, use the food from the soil, they cannot grow; but provided they have water, why should they not remain as they were? What are they doing to make them lose weight?

Well, they are doing just what all living things do, and must do, if they are to remain living; they are breathing! breathing as animals do, though they have no lungs, and though they breathe very much more slowly. That is to say, they are taking in air.

In breathing, as has been said, part of the oxygen of 


\section{Leaves and their Work}

the air inhaled combines with, and burns up, part of the carbon taken in as food, converting it into the gas carbon-dioxide, which is breathed back into the air. Warm-blooded animals breathe much more vigorously than plants do, but the process is the same in both.

Plants, however, breathe more or less through their whole surface, though chiefly through their leaves, and from the leaves, the air finds its way to every part.

Probably the breathing of plants may be fairly compared with the slow breathing of cold-blooded animals; but though feeble it is always going on, night and day, in light and in darkness, though more vigorously in light; and, therefore, as the stock of carbon is gradually burnt, or oxidized, and breathed out, if it is not replenished it must be gradually exhaussod, and the plant must lose weight.

To prove this two beans of nearly equal weight were planted at the same time, one being kept in the dark, the other in the light. At the end of twenty-six days it was found that the seedling kept in darkness weighed more than a third less than the original bean, and the other weighed more than a third more. The one had breathed away some of the carbon contained in the thick seed-leaves without being able to extract any from the air to feed upon, while the other had obtained food enough for growing and breathing, too.

There is some difference in the breathing of the leaves and the blossoms of a plant. The blossoms breathe faster than the leaves, especially when they are just opening ; and they are therefore slightly warmerin some cases, indeed, so warm that the heat may actually be felt! And the same is true of sprouting seeds when there are many together. The sprouting 
barley, for instance, from which malt is made, gives off quite a high degree of heat.

As the plant, like the animal, must breathe in order to live, it must needs have a constant supply of air for breathing, as well as feeding, purposes. And this air is necessary, more or less, not only for leaves and blossoms, but for all parts, including stems and roots. It breathes through all, though chiefly by its leaves and blossoms; and the roots are always breathing out carbon-dioxide into the soil. If the soil be too close, or baked on the top, the roots cannot get enough air to breathe properly, and the plant is sickly. And the same thing happens when soil is piled up round the stem, for the air is then kept away both from it and from the roots, and many a tree has been killed in consequence.

Leaves covered with dust, or smoke-particles, cannot possibly thrive, for they are choked, just as much as an animal would be if kept without air ; and besides being unable to breathe, they are also unable to take in food. The whole plant, therefore, suffers, and unless relief came from time to time in the shape of rain to wash the leaves, it must die of suffocation.

The patient, laborious Chinese, who were the first to attempt market-gardening in the sandy environs of Melbourne, were so well aware of the fact that plants cannot thrive when choked with dust or sand, that they were in the habit of washing their vegetables, leaf by leaf, three times every day to keep them in health. 


\section{XIII.}

\section{CLIMATE}

THE plant's whole life depends, as we have seen, upon the sun, for without sunlight it cannot obtain carbon from the air and must starve. And this is equally true whether the plant manufactures its own food or whether it feeds upon what has been manufactured by others. The parasite sucks the juices of plants growing in the light; the fungus feeds upon dead vegetable matter which has grown in the light; the seedling lives at first upon food stored in the seed, by the leaves which waved in the sunlight, and so on.

But plants require of the sun something more than light; they must have some degree of heat as well-a very small degree in some cases, but this small degree is essential to bring them to maturity. Even those lowly plants which grow in snow and ice cannot dispense with some amount of heat, and though they, contrive to exist in the lowest temperatures, they remain dormant during the winter, and only wake up when the summer sun begins to shine.

Many seeds will even begin to grow while it is freezing, though they cannot make much progress; and wheat has been known to germinate when actually 
upon ice, and to send out roots into it. Barley and oats will also send out roots with the thermometer down to freezing-point, but they cannot develop seedleaves without a few degrees of warmth. Maize, as might be expected, requires more heat than any other corn, and will not start until the thermometer shows about $15 \frac{1}{2}^{\circ}$ above freezing, and even then grows but slowly; and cucumber-seed shows no sign of life without still more heat.

But, though many seeds will make a start in cold weather, even in frost, it does not follow that they will do more than start; for a plant requires different degrees of light and heat at different times in its life. And if it does not receive enough at the important period when it has done growing, and is going to blossom, the chances are that it will bear no fruit. For fruit cannot do much towards feeding itself, and though it does take up carbon from the air, it is chiefly dependent for nourishment upon the leaves, the great food manufacturers. But, in a cold summer, the leaves, instead of passing on their stock of food to the fruit, and themselves turning yellow, as they ought to do, seem to be quite thrown out of their calculations. They keep their food to themselves, and remain green and juicy, while the fruit is starved, and its development checked. In very bad cases, the plant puts out new shoots, and the crop never comes to perfection; for the heat which is quite sufficient for the growth of stems and leaves is not sufficient for the growth and ripening of the fruit.

If, on the other hand, the piant gets too much lignt and heat at an early stage in its life, it grows up and ripens its fruit too quickly, before it is properly 
developed; and this is what takes place when crops are sown too late in the year. In the ordinary course of nature, seed generally drops and sows itself as soon es it is ripe, and begins to grow forthwith. But it cannot go on growing. Winter comes and checks it, and it is obliged to put off bearing fruit till the following summer. Plants grown in this, the natural way, are generally the stronger, if they manage to survive the winter. But they are exposed to more perils than when the seed is sown in spring, and of course they are much longer in coming to perfection.

Barley sown early in August and'September, as soon as it is ripe, has been found to take two hundred, and two hundred and forty days, to come to perfection, which is just eight times as long as it often does in Egypt, where it is sown and ripened not only the same year, but quite early in the year.

Provided, however, the seed be not sown too late, the crop seems to be equally good whether the seed be sown in autumn or spring. Barley sown for experiment on the 2Ist of April came to perfection in eighty-eight days, that is, by the I8th of July; whereas that sown five weeks later ripened, indeed, in an equal number of days, but prematurely, before the grain was properly developed, because it had been over-stimulated-too much hurried, in fact, during the long, light, warm days of June.

Of all the influences by which the plant is surrounded, none affect it so powerfully, for good or evil, as light, temperature and moisture, or, in one word, climate. Where the climate is favourable, the quality and quantity of the soil are of comparatively little importance, for the plant manages to make the very utmost 
of what it has. But, where the climate is unfavourable, no soil, however good and abundant, can make up for it, though it may do something to lessen the evil consequences.

As we have already seen, the richest soil is unable to supply the place of water; while in Guiana, on the other hand, where moisture is abundant, and the climate genial, groups of trees may be seen growing on a spur of the great sandstone mountains, wherever there is just sand enough to afford them a foothold. The sand is, of course, not mere sand, though it may look like it; but the soil is undeniably poor and shallow. Yet, helped by the climate, the trees thrive, as they could not possibly do without that help.

We are naturally accustomed to look upon the sun as the source of light and heat to our planet; but temperature does not depend solely upon the sun; for if it did, the same temperature would prevail all along the same parallel of latitude, which it certainly does not.

Rhine grapes, for instance, will not ripen in England; laurels and camellias flourish all the year round on the coast of Cornwall, while in the same latitude on the continent, only the hardiest trees can stand the winter. The vine can hardly flourish at the mouth of the Loire; yet it comes to perfection in Tokay, which lies a degree further to the north; and Astrakhan, in nearly the same latitude, has summer-heat enough to ripen the southern fruits of Italy, and even of the Canary Islands, though its winters are so severe that no vine-stock would be able to live through them without being buried several feet deep in earth.

In Germany, where the summers are much hotter than in England, roses, and other trees and shrubs, 
which we do not think of protecting, are matted up like mummies for the winter.

Then again, myrtles will flourish out of doors all the year round in Ireland, as well as they do in Portugal; but plums and pears do not usually ripen well, though they will do so perfectly on the continent, in the same latitude.

It is evident, therefore, that the climate of a country does not depend solely upon its position with regard to the equator. Indeed, the great characteristic of the equatorial climate is, not so much its heat, as its wonderful uniformity. Hot it is, of course, though not as hot as the plains of North India; but there is nothing to be called change of season, and there is seldom more than $16^{\circ}$ or $17^{\circ}$-of difference between day and night. It is not often that the thermometer stands above $90^{\circ}$ or $9 \mathrm{I}^{\circ} \mathrm{F}$. by day, or falls below $74^{\circ} \mathrm{F}$. by night. And the temperature of the soil varies but little, too. Four or five feet below the surface it never varies at all, and remains constantly at $80^{\circ} \mathrm{F}$., just about half-way between the temperature of night and day.

Where the temperature of the air varies more, there the temperature of the soil varies more also, and to a greater depth. At the equator, the sun affects only the upper four or five feet of the soil, the change between day and night being unfelt below this; but in England the change between summer and winter is felt to a depth of fifty or sixty feet probably; and below this the temperature remains steady at but a little above $40^{\circ} \mathrm{F}$.

$40^{\circ} \mathrm{F}$. is about the mean temperature of the air in England, as $80^{\circ} \mathrm{F}$. is that of the equatorial region- 
half-way between the two extreme points to which the thermometer rises and falls.

But this fact, that the depth at which the temperature of the soil remains always the same is so much greater in one case than in the other, has much influence upon the two climates; and for this reason: whenever a hot body is in contact with a cold, or cooler one, it at once gives up some of its heat to this other, and continues to do so until there is no difference between the two.

When, therefore, the sun warms the surface of the soil, the upper layer parts with some of its heat to the one below it, this to the next below, and so on, until that depth is reached where the temperature is always the same. At the equator, therefore, the heat, having only four or five feet of soil to travel through, soon raises the temperature of the whole mass equally, and then, as it cannot descend any lower, it goes on adding to the heat of these upper layers, in which it accumulates. At night, when the sun is gone, the surface of the soil cools, and the reverse process begins : the heat stored during the day gradually passes up again to the surface, and from the surface into the air, so that both earth and air are kept at a more even temperature than would otherwise be the case.

But where, as in England, the sun has forty or fifty feet of cool earth to warm, naturally it is much longer about it, and the whole mass is consequently not warmed equally through till summer is at its height. Then, and not till then, the whole mass being warm, heat begins to be stored during the day in the upper layers, and is given up again, when the sun is down, to warm the air at night. Hence we have warm nights in 
July and August; and winter is less cold than it would otherwise be, thanks to the heat gradually given back by the great mass of earth.

But the heat given back to the air in this way would quickly escape, and benefit us little, were it not for the moisture in the air, which acts the part of a blanket, and keeps it near the earth. At the equator, the air is generally in a very moist condition all the year round; and this moisture, while serving the part of a blanket by night, acts as a veil or parasol by day, and prevents the sun's rays from being too scorching.

It is to the large quantity of moisture in the air that the region of the equator owes its very even temperature, therefore.

In the dry plains of North India the heat is scorching, much greater than at the equator, just for want of this veil ; and the nights are often so cold that water is frozen, because the heat received by day all escapes again through the clear air.

Everybody knows that a clear night is a cold night, while a misty or cloudy one is comparatively warm.

Among other circumstances, therefore, which greatly affect the climate of a country is its nearness to or distance from the ocean. For where constant evaporation is going on, on a large scale, as, of course, it is from the ocean, there the air must needs be loaded with moisture, with the consequences already mentioned: the nights are warmer, the days cooler, the winters less severe, the summers less scorching. In qne word, the climate is more equable. Moreover, the ocean is warmer than the land, in winter and by night, while it is cooler, in summer and by day; and this tends to further equalize the temperature. 
Winters are colder and summers hotter in Germany than in England, mainly for this reason-because the air is so much drier owing to the greater distance of the ocean. For the same reason, plants and shrubs need protection there during the winter which they do not here; and, on the other hand, grapes will ripen there when they will not here.

But, besides these general circumstances, there are also various local circumstances which affect climate more or less. Thus, if the neighbourhood of the ocean tends to equalize climate, the neighbourhood of any large expanse of dry soil does exactly the reverse, inasmuch as it dries the air.

If the Sahara were covered with water, the climate of the South of Europe would be many degrees less warm than it is; for the wind passing over it would be cooled, instead of heated as it now is. It would also be moistened, and so more snow would fall in the Alps, and less would melt in the summer.

Then, again, there are the many ocean currents, hot and cold, which also influence climate to a considerable extent. Western Europe would be far colder than it is without the Gulf Stream, which brings about 166,000 cubic miles of hot water from the tropics to the North Atlantic in the course of each year. And this tremendous volume of steaming water, besides warming the air, loads it with moisture; so that it is easy to understand why the winter climate of Ireland should be mild enough to allow of myrtles flourishing out of doors, and yet why the summer heat should not be sufficient to ripen fruit, owing to the thick veil of vapour which screens it from the sun.

Other local circumstances which affect climate in a 
greater or less degree are the presence of forests, rivers, lakes, mountains, which cannot now be dealt with in detail.

But plants are also affected in a minor degree by the colour of the soils in which they grow.

Dark substances absorb more heat than light ones do; and snow will melt more quickly if a piece of black cloth be stretched above it, even though the two do not touch one another. In the Arctic regions the ice melts much faster wherever a small dark-brown plant, of the same family as the Red Snow, grows, because it attracts the heat. So, too, in some parts of Switzerland the peasants hasten the departure of the snow by strewing it with black powdered slate.

Dark soils are therefore usually warmer than light ones; and it is not an uncommon thing for gardeners to sprinkle a light-coloured soil with peat, charcoal, or vegetable mould to warm it, for these all act as suntraps.

Melons are thus ripened, even in the coolest summers, at Freiberg, in Saxony, by means of a layer of coaldust.

Grapes, too, in the Rhine district, ripen best where the ground is covered with fragments of black slate; and the vines are purposely kept near the ground, that they may have the full benefit of the heat which the slate absorbs by day and gives up again by night.

The difference in temperature between two substances, one of which is white and the other black, when both are equally exposed to the sun, is very remarkable. There will be as much as thirteen or fourteen degrees difference, for instance, in the temperatures of a piece of lamp-black and of a pie e of magnesia. 
But though colour makes such an important difference in the power to absorb heat, it has no influence, apparently, upon the power to retain it. Indeed, though sand may absorb heat less quickly than a darker soil does, when once it is warm it remains warm longer than any other. The coarser it is, too, the less quickly it cools ; and as coarse gravel, once thoroughly heated, retains some degree of heat even through the night, it is found useful to put it round grape-vines to keep them warm.

Great, and especially sudden, changes of temperature are particularly trying to most plants, though such as grow in deserts have become so accustomed to being scorched by day and frozen by night, as at least to manage to keep alive. But though an even temperature is in some ways most desirable, it does not by any means follow that all plants would thrive in the equatorial region. That region, as has been said, is characterized less by its great heat than by its remarkable uniformity of climate. It knows no change of seasons : it is always summer, always spring, and always autumn there, and many trees bear both flowers and fruit at the same time. But this constant activity, though it suits the trees and plants accustomed to it, is too much for our European fruit-trees and other plants; for these are in the habit of taking a winter sleep, and cannot get on without it. Transported to the equa. torial region, they grow, indeed, freely enough, but too freely; for they become evergreen, putting out fresh leaves all the year round, and are so exhausted for want of their customary rest that they are unable to ripen their fruit. This is the case even when they are taken to the cooler hill-country of Ceylon; and it is 
true even with regard to the vine, which, though a native of warm climates, still is not a tropical plant, and is accustomed to shed its leaves year by year. In the tropics, however, its leaves remain green, instead of giving up their stores to feed the fruit as they ought; the grapes fall off almost unformed, and the vine puts all its energy into growing leaves instead of fruit, not having strength for both. The one thing which it lacks is rest-the rest which in winter it is compelled to take.

It being, however, impossible to provide the vines with winter-cold in Ceylon, it was suggested that heat might perhaps be made to answer the purpose as well, and the experiment was tried of laying the roots bare for a time to the strongest sun. This had the effect of checking the flow of sap as effectually as frost could have done: the leaves dropped, the vines had their sleep, and awoke from it so refreshed and invigorated that they were able to bring their crop to maturity; and this plan has been adopted with success both in Ceylon and Bombay.

In those tropical regions, outside the equatorial belt, where there are periodical rainy seasons and long droughts, the latter answer all the purpose of winter, and are, indeed, winter, so far as vegetation is concerned, in spite of their intense heat. Trees and shrubs are as leafless in the desert of Nubia, for instance, before the rains set in, as if it were mid-winter, in spite of, or, rather, in consequence of, the terrible heat ; and thus a time of rest is secured to them.

In the far north we have a very different state of things. Here, instead of its being necessary to secure that the plants shall have rest, the great thing is to 
provide that they shall make the utmost of the very short spring and summer which are all that fall to their lot. Their time of sleep lasts on an average ten months, and during the remaining two months they have everything to do, so that it is most necessary that they should make the most of their time. The days are of course very long, which is a help, while the nights are so light as to be hardly like night; and if Professor Nordenskjöld's observations be trustworthy, it seems that the plants do indeed turn every moment to account, by growing all night as well as all day.

But many of them do a great deal of growing in advance, so that as soon as the summer comes their blossoms and fruit, which need heat more than the leaves, may be ready at once to take advantage of it. These plants, that is to say, make very large, strong buds, which are packed full of leaves and blossoms in a more or less undeveloped state, but with all their parts ready, before the winter sets in. Directly the growing time comes round again, therefore, they can burst out, and begin to gather food from the air at once, and the plant is able to blossom very early, thus ensuring as much time as possible for the perfecting of the fruit.

Most of the plants ripen their fruit, but some few are not able to do so, except now and then, when the summer is hotter or longer than usual; and some which are annuals further south become perennials here, as they would not have time to grow from seed, and ripen seed, in one short season.

During the long winter many are of course protected by the snow; but there are wide surfaces here and there left quite bare of covering, and yet even here plants manage to survive, some without any protection 
whatever, others because they are buried under a deep layer of dead leaves and stems.

But though they bear the intense cold without injury, it is quite evident that even these dwellers in the Arctic regions enjoy a little warmth when they can get it, for they are most abundant on sunny slopes and in sheltered nooks and corners. Many of them, indeed, crouch close to the ground, and few venture to raise their heads very high; trees there are none, the bushes are dwarfs, with few and small leaves, and the vegetation generally is on a miniature scale. Still, there is vegetation; and whether in 'deserts' of ice or 'deserts' of sand, it would be equally difficult to find any spaces of large extent where vegetable life of some kind or other does not exist, at least during certain seasons of the year. 


\section{XIV.}

BLOSSOM AND SEED

Plants, even the very humblest and lowliest, have, as we have seen, many requirements in the way of food of various kinds, water, air, light, and warmth. But having seen them duly provided with all these, we might fancy that now at last all their wants were satisfied, and that nothing more remained but for them to make the best of their opportunities and-grow.

But all depends upon what we consider to be the plant's object in life. For instance, we may be quite satisfied to grow orange-trees for their blossom merely, or maize for use as forage, and palms for the sake of their foliage, in climates where it is impossible for any one of them to ripen their fruit. And provided they throve and answered these purposes, our object would be attained.

But plants in the natural state grow to bear and ripen fruit. All the rest of their lives is merely a preparation for this one grand end. The roots draw food from the soil, and the leaves do the same from the air, all for the purpose of feeding and maturing the fruitthe one aim to which everything tends.

Of course, where man comes upon the scene it is 
quite another matter, as he can take cuttings of some, divide the roots of others, and fetch continual supplies of seed from the ends of the earth, if necessary. But the wild plant has not these resources to fall back upon, and if its race is to continue, it must as a rule be able to perfect its seed, otherwise it will merely thrive for a time, longer or shorter, according as it is an annual or a perennial, and then it will perish without descendants.

But in very many cases the plant, like Mr. Belt's scarlet-runners already mentioned, is quite unable to perfect seed without the help of what we may call nature's under-gardeners. The plant does much for its offspring; it collects and stores food, it drains itself of its own life-juices for their benefit, but it cannot always do everything; and if these under-gardeners were banished from the earth, some plants would speedily vanish also.

Both blossoming and fruit-bearing are processes more or less exhausting to the plant, for neither flowers nor fruits do much, though they do something, towards feeding themselves. Annuals blossom and bear fruit once and then die entirely, roots and all, their leaves and stems being drained of nourishment by the end of the season. Others, perennials, die down, but their roots remain alive; and others again, merely shed their exhausted leaves, and grow fresh ones, for several or many seasons in succession. Others again, take more than one season to store food before they venture upon the expense of having blossoms at all; and others take many years to prepare for this great effort, and when it is at last accomplished, the great end of their lives, they die of mere exhaustion. 
The food of blossom and fruit is, as has been said, very generally accumulated in the leaves and stems of the plant; but sometimes the root serves as the main storehouse. The turnip, for instance, like other biennials, spends the first year of its life in doing nothing but gather a store of food by means of its roots and its tuft of leaves. It does not shoot up, and it makes no attempt to blossom; and as the farmer does not want turnip-blossom, and does want roots, he takes the latter while they are plump, and well-filled with the food intended for the seed. If he waited till the next year he would see his turnip-plants shoot up rapidly and blossom; and very thriving they would look, no doubt; but all this time they would be sucking away at the roots, which would be losing their plumpness, and growing gradually hollower and more hollow, until, by the end of the second year, they would be reduced to nothing but fibre, and be quite useless.

We have spoken already-of bulbous plants, such as crocuses, whose blossoms are nourished on the food previously stored for them in the bulb, by the leaves, which, in most cases, do the chief part of their work after the blossoms have faded. But in some instances, as in that of the colchicum, or meadow saffron, they come up and make their preparations in the spring, for the blossoms which do not appear till the autumn, long after the leaves have vanished. In these cases. the food for the blossoms is stored in the bulbs; and if a tidy gardener unwarily cuts off the leaves before the bulb is properly stocked, he starves the blossoms.

But some plants take years to prepare food sufficient for the supreme effort of their lives. 
The American aloe, for instance, which was supposed to blossom only once in a hundred years, though it does not wait quite so long as this, does actually wait five or six years in its own country, and from fifty to seventy in ours, before it attempts to send up a flower-spike. But when it does begin, it grows with such tremendous energy-at the rate of a foot a day even in our conservatories-that one can well understand its need of a large store of food ready for immediate use, since it would be impossible for leaves and roots to collect, manufacture, and supply it as fast as it is wanted.

The aloe does not, however, always die of its effort, and may live to blossom again, some years later; but the Talipot palm, though it attains a great age, spends its whole life in accumulating food for its progeny; and having once blossomed, it is quite exhausted and perishes.

Blossoming, then, is a serious matter for all plants, and not to be undertaken without due preparation. But it is a curious fact that the size of a plant's blossoms is often quite independent of the size of the plant itself. Many a forest-tree, for instance, bears flowers which are quite minute and insignificant; others, as some of the palms, bear spikes of blossom several feet in length and leaves in proportion. As a rule, however, trees have small leaves, small dull blossoms, and small seeds for their size; but they bear all three in large numbers. A diminutive cactus, only a few inches high, on the other hand, may boast a glorious crimson flower, measuring two or three inches across; but, then, it has to be satisfied with one or perhaps two. The beautiful night-flowering cactus attains some size, 
but it is a conservatory plant, not a tree, yet its blossoms measure half a foot across and it bears at times as many as twenty or thirty together.

The largest known blossom, however, is that of the extraordinary Rafllesia Arnoldi, a native of Java and Sumatra, which, much more truly than even the orchids, is 'all blossom,' for it has neither branches, leaves, nor roots. Of course, therefore, it must needs be a parasite, living by and sucking the life-juices from others; and it produces a huge blossom, more than a yard across, mainly at the expense of the vine-like plant upon which it fixes itself.

It is not by any means a beautiful object, and its petals, which are thick and fleshy in texture as well as flesh-coloured, have the smell of tainted beef. This monster takes several months to come to perfection, and then weighs about fifteen pounds; after which it begins, in a few days, to wither away.

An ordinary, complete, simple blossom, whether large or small, brightly coloured or inconspicuous, consists of two sets of parts, or organs, an outer and an inner set. It is the function of the inner set to form the seed; and it is the function of the outer set to protect the inner from all injury, and also, in many cases, to attract the under-gardeners already referred to, whose good offices are required for the development of the seed.

The perfecting of the seed is the great thing to be accomplished; and those parts of the blossom which contribute to this object are placed in the centre, as far out of harm's way as possible. If we examine, for instance, a common primrose, splitting it carefully 


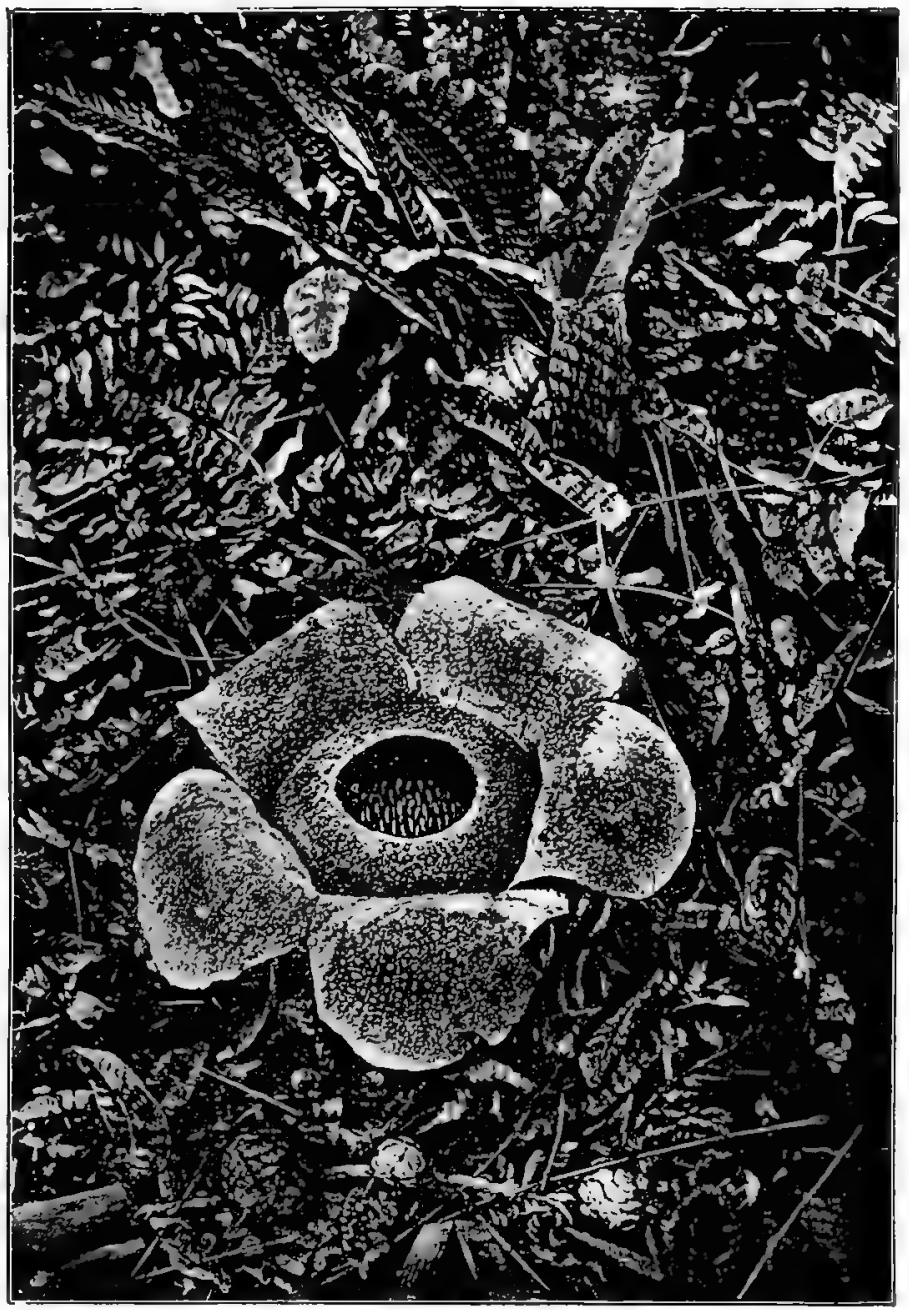



upwards from the base of the flower, we shall see in the very centre a hair-like stalk, with a knob at the upper end and a hollow swelling at the lower end. On splitting open this hollow part, we find that it contains a number of very minute grains, ovules, or little eggs, which, in the ordinary course of things, would be converted into seeds.

This central organ is the pistil, which consists of

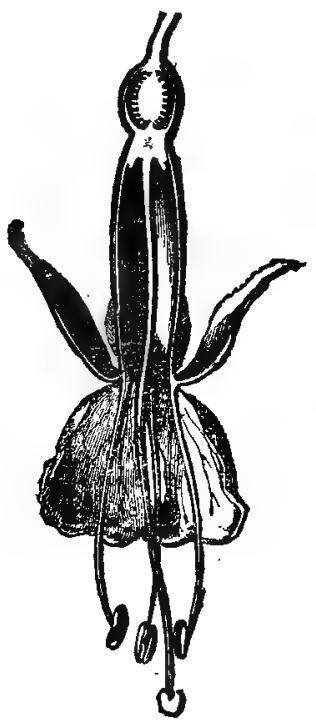

Section of Fuchsia-blossom.

one or more bodies, named carpels, each with its hollow case, or ovary, below, and its stalk, or style, above; and these are either distinct one from another, or combined into one organ.

Outside the pistil stand the dust-spikes, or stamens, -stalks bearing each a double sac, or anther, which is filled with the dust known as pollen. Pistil and 
stamens together form the inner and more important set of organs.

The outer set consists of a double envelope of leaves; the inner, or petals, more delicate in texture and more varied in colour, forming the corolla; and the outer, or sepals, generally green, and forming the calyx. A perfect flower has all these parts, and some have double rows of each. Naturally our eye is attracted chiefly by the brightly coloured part of a blossom, and we think little about the inner organs, which are often almost or quite hidden from our sight. But it is these inner organs which are really the only absolutely necessary parts of a blossom.

Many flowers have no calyx at all; some have no petals; but, provided they have stamens and pistil, they can still accomplish all that is necessary for the perfecting of their seed. Even pistil and stamens, however, may be, and often are, reduced in size and deprived of their stalks; but dust-cells there must be, and ovules, or grains to be developed into seeds, there must be if the plant is to bear seed at all.

Now all these organs, the inner set as well as the outer set, are really leaves-leaves whose appearance and duties in life have been altered. The calyx still looks more or less leaf-like usually, and it is not difficult to believe that the petals might be leaves too, though more delicate and more daintily coloured. But it is less easy to believe the same of stamens and pistil. Let us, however, look for them in any double blossom, and we shall find few if any, for they have been changed into petals. It is blossoms with many stamens, such as the rose, ranunculus, anemone; or blossoms with many florets, such as the daisy and 
dahlia, which are most commonly doubled by cultivation.

Nature does not grow many double flowers, for wild plants need seed, and double flowers produee little if any, seed being sacrificed to petals. Geraniums, which have only ten stamens, are among the plants, however, which have a tendencý to increase the number of their petals; and, among the single blossoms, one may often be seen with a petal or two more than the rest, or an extra small petal, which is half way between a petal and a stamen. If the seed from this blossom were saved, some of the next generation of plants might have still more petals and still fewer

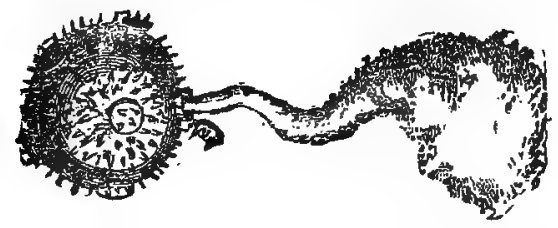

Pollen of the Melon, magnified.

stamens, and by carefully cultivating those having these peculiarities the gardener would at last obtain quite double blossoms. The orange day-lily, too, may sometimes be seen with one or more stamens enlarged into small petals and bearing an imperfect anther.

But we have now to see what it is which changes the little immature grains in the hollow part of the pistil into seeds, capable of growing into independent plants. At first they are mere specks of matter to all appearance, and so they will remain unless they are brought into close contact with some of the dust contained in the sacs borne by the stamens. This is the special stimulant which they need to make them 
develop, and if it be kept from them they will simply shrivel and die, for nothing else will do instead.

This dust, or pollen, is contained in the anther, which is usually seated, or more often perched, and apparently very loosely perched, too, on the end of a stalk.

When the pollen is ripe, that is, ready for the use of the grains contained in the pistil, the chambers open and it is discharged. The pollen consists of hollow grains, varying very much in size and shape in different plants, though always alike in the same plant.

Pollen-grains are very beautiful objects when seen through the microscope, though they look like nothing but powdery dust to the naked eye. Their colour is usually yellow or brown, but they are also red, green, blue, whitish, and even black; and though their general shape is round, or egg-shaped, they are of many other forms, wonderful in their great beauty and variety, and reminding one of microscopic shells.

Some pollen-grains, for instance, are covered with ridges or 'grooves; others, such as those of the hollyhock and aster, with spines; others again with hairs or thorns; those of the thistle are many-sided; of the fuchsia and evening primrose, triangular; of the chicory, six-sided; and, if we could see, we should no doubt find a reason for every change of form and colour, and discover that each was exactly adapted for its own special purpose.

Every pollen-grain is delicately coated with oil, probably as a protection against damp and wet, and all have upon them markings, like pores or slits, to some of which there are lid-like covers. Usually each grain consists of a single cell, though sometimes there are 
more, and the cells are filled with a liquid of a most nutritious kind, consisting partly of starch, partly of oil, and partly of some jelly-like nitrogenous compound.

It is pollen which is the flesh-forming food of the bee. It may live on honey, which is mainly sugarnot nitrogenous-during the winter, when it is doing no work, but when it is taking long journeys to and fro, it needs something more nutritious to make up for the waste occasioned by so much muscular exercise, and it eats pollen, besides carrying it home to make bee-bread for the young grubs.

But our concern now is with the ovules, the possible

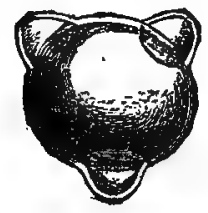

Pon.en of Wheat.

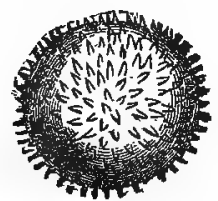

Pollen of the Hollyhock.

seeds, lying enclosed in the ovary at the base of the pistil, while the pollen, which is to make seeds of them, is in the anther-sacs above, and, as it would seem, out of, and beyond their reach. The question is, how are the two to be brought together?

In describing the primrose, we mentioned that the top of the pistil ends in a knob; and this knob is a matter of great importance. It is called the stigma, and is of all sorts of different shapes in different flowers; sometimes merely a point, sometimes large and divided into lobes, sometimes feathery, as in most of the grasses; but whatever its shape, it has no covering of outer skin, as the stalk on which it is borne has, and it is more or less sticky, and often crowned with a bead of nectar. This bead is so large 
in some plants-as, for instance, the white lily - that it may be taken off; and if then a few grains of pollen from the anther be sprinkled upon it, we shall see that these will in about half an hour begin to swell and grow. Each grain will put forth a slender tube, very minute, of course; but in an hour or two it will have lengthened out, and the fluid contained in the pollen-

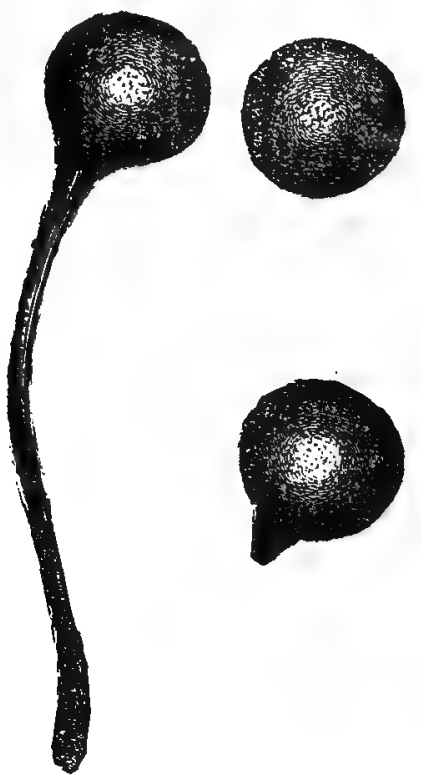

Throwing out the Pollen Tube.

grain may be seen passing down one side of the tube and up the other. Pollen-grains may also be grown in a solution of gum or sugar.

Now this is exactly what takes place when pollen falls upon the sticky stigma at the tip of the pistil, only that instead of growing in an objectless way, each grain 
sends out its tube, or sometimes several tubes, in the most business-like manner, and with the most precise and definite aim. The object is to reach one of the ovules below, and to do this the tube, in many cases of more than hair-like fineness, pierces its way downwards through the stalk of the pistil, and makes straight for its aim with unerring exactness, entering one of the ovules by an opening in it which exists for this purpose.

Sometimes the tube may take months to reach the ovule, but more usually it accomplishes its purpose in a few days or hours. As soon as it has made its way into the ovule, it begins to pass into it the fluid contents of the pollen-grain, and the ovule begins to grow.

But the ovule does more than grow, it acquires a new character. At first it was a mere speck of matter, containing a germ-cell, indeed, but no germ, no rudimentary or embryo plantlet, such as one may see on splitting open a bean, pea, nut, or any other seed large enough for the purpose. The tube sent out by the pollen-grain enters the ovule, and the germ is developed and vivified by the liquid which passes down it. The seed, which before was unfertile, and could never have germinated and produced a plant, is now fertilized, made fruitful, and if allowed to come to maturity it will be capable of producing a plant like that by which it is borne.

It is quite possible in certain cases for ovules to grow and even to attain the size of seeds without being seeds, without having within them any living germ capable of independent life and growth. For each ovule is attached to the walls of its nursery, as one may see by looking at the peas in a pod, and is fed from the leaves. 
But unless it receives also the liquid contained in the pollen-grain, it remains lifeless, and sooner or later shrivels and perishes.

The quantity of pollen prepared and needed for the ovules varies very greatly in different plants. The violet, for instance, produces about a hundred grains in each blossom, and the poppy more than three million and a half. Some ovules need only two or three grains of pollen to quicken them, and others several; some of the foreign orchids bear as many as seventy-four million seeds, and though they are very small, each seed requires the contents of about twenty grains of pollen to fertilise it; so that the quantity produced is necessarily very large. Moreover, a good deal more is required than the plant itself needs, as a considerable margin must be allowed for waste, some being blown away by the wind, some washed away by rain, and not a little consumed by bees and other insects.

Since the pistil with its sticky tip stands in the middle of the blossom all ready to catch and hold fast the pollen which is discharged by the surrounding dustspikes, it would seem that there could be little difficulty about the matter, and that stamens and pistils might safely be left to manage it without help. But there are various obstacles in the way of this apparently simple arrangement.

In the first place, even though stamens and pistil be most conveniently placed, as it might seem, for the very purpose of giving and receiving pollen, it does not follow that they are so. For where is the use of their being within easy reach of one another if they are not both ready to act at the same time? And this is a thing which happens very frequently indeed. Some- 
times the pistil is ready first; its tip is unfolded and sticky, and waiting for pollen, before that of the surrounding stamens is ripe enough to burst from the anthers. But the pistil cannot go on waiting, and if pollen does not reach it at the right time, it is of no use its coming at all ; the time is gone by, and the ovules are left to shrivel.

Often, too, the pollen is ripe first and all scattered before the pistil is ready for it; and here again the ovules must perish, unless pollen is brought from elsewhere. Even when pollen and pistil are ripe together, they may be out of one another's reach ; for the pistil may be taller than the stamens, or the anthers may open outwards instead of inwards, and in neither case will the pollen be scattered on the pistil-tip, or be of any use to the ovules.

But there are more difficulties even than these. A perfect flower, as has been said, consists of a double set of outer and a double set of inner organs ; but very many flowers are quite imperfect. One or both of the outer set of leaves may be altogether wanting, and one or other of the inner set may be also wanting. That is to say, some plants grow the pistil in one blossom and the stamens in another, but never both in the same blossom; and others go a step further than this, and grow their pistils and stamens not merely in different blossoms, but on different plants.

Those plants or blossoms, which bear stamens only, are of course barren, for they possess no ovules, as they possess no pistils; and those which bear pistils only are, or may be, fertile, since they possess ovules, which may become seeds provided pollen be brought to them from another blossom or plant, but not otherwise. 
And then, again, even when a plant bears perfect flowers with both pistils and stamens, it not unfrequently happens that pollen from their own blossom, or from another blossom on the same stalk, does not suit the ovules. Some which are fertilized by the pollen of their own blossom, close-Pertilized, as it is called, do well, and the seed is plentiful; but in most cases it is poor and even worthless. Sometimes the pollen from a blossom on the same stalk actually has the effect of poison, and when applied to the pistil-tip, causes it to shrivel and decay, and makes the petals drop; sometimes, again, it does neither good nor harm directly; it does not poison and it does not fertilize, but-which is equally injurious-it prevents any other pollen received afterwards from having any effect, so that in either case the ovules are equally sure to shrivel. Then, further, there are some plants, as, for instance, certain of the passion-flowers, whose ovules cannot be converted into seeds unless they receive pollen not merely from another plant of the same species, but from another plant of a different species-a passionflower, but a different species of passion-flower.

Such, then, being some of the many arrangements by which it is made difficult or impossible, for ovules to be fertilized by pollen from their own blossom, or from a blossom on the same stalk, one must conclude that there is some reason for them, and that seed is the better for being cross-fertilized-fertilized, that is, by pollen from another plant. And so, indeed, it proves; for if cross-fertilized and self-fertilized seeds be sown together, it generally happens that the former grow up so much the stronger as quite to overpower the rest. As a rule, then, cross-fertilized seed produces much 
more vigorous plants than self-fertilized seed does. But still, as wild plants have to keep their own place in the world, which they cannot do without offspring, it is better for them to have some seed, even poor seed, rather than none at all. And to ensure this some plants manage to bear seed of both sorts ; some fertilized by the pollen of its own blossom, some if possible by that brought from outside, so that if by any chance the latter should fail, they may still have something to fall back upon.

There is, for instance, that ubiquitous little plant, the common chickweed-weak-stemmed and fragilelooking, but not in the smallest danger of dying out, for it goes on sowing itself through many months of the year. Its first crop of seed is fertilized quite early in the spring, so early that the plant is left to itself, and has to make the best of its own pollen, which it does in the most thrifty way possible.' The pollen is never scattered, so there is no waste, but, while still in the anther-sacs, it sends out tubes in the direction of the pistil-tip, which it reaches without fail. This process takes place while the flowers are still only buds, so that pollen and tubes are carefully protected. The seed thus produced may be poor, much of it may even be useless, but at least what there is, is better than none; and later in the season, if circumstances are favourable, better seed will be produced by pollen brought from other plants.

Generally speaking, pollen grains do not begin to swell until they actually touch the moist tip of the pistil, but in these early blossoms of the chickweed and some other plants, they never leave the anthers. The sweet violet, in like manner, bears some buds, 
smaller than the rest, which never open. These produce but a few grains of pollen, as there is no waste to be allowed for, and they send out long tubes without leaving the anthers.

The dog-violet, on the other hand, as it does not resort to this device, is quite seedless, unless pollen be brought to it; and other plants are much worse off, and can never set seed at all in this country, being unable to make use of their own pollen, and not finding here the messengers which, in their native land, bring them pollen from other plants. The Greater Periwinkle is one of these, and never has seed.

As has been mentioned, some blossoms have pistils so much longer than the stamens that it seems impossible for the pollen of the one to reach the tip of the former. This is the case with the colchicum, whose mauve-coloured blossoms are much like those of the crocus. But when the pollen is ripe and the anthers have burst, some of the dust is rubbed off upon the inside of the petals when the flower closes, as it does every night several times in succession. Meanwhile the petals lengthen so much that, when the blossom closes for the last time, the first spots of pollen are brought up to a level with the tip of the pistil and are pressed against it, with the result that some of the grains adhere to the sticky surface and soon begin to grow, at the rate of something more than an inch in an hour.

In the case of the colchicum, the ovules are a very long way from the pistil-tip-as much as thirteen inches-but they are reached in about twelve hours. This takes place at latest at the beginning of November; but, for some reason, perhaps because it 
needs warmth, the germ or embryo does not begin to form in the ovules until the following May.

The ovules of the American oak wait almost a year after the entrance of the pollen-tube before they begin to develop, and then take another year to ripen.

Why should the pollen-tube always grow with its end directly towards the very narrow opening by which it is to enter the ovule?

For the ovule is often far away-what, considering the size of the pollen-grain, may be called, without exaggeration, hundreds of miles away-while the door by which alone the tube can find entrance is the merest point. Indeed, the ovules themselves are often mere specks, and usually they are placed in what looks like a most inaccessible position, quite enclosed in the ovary. Often, too, there are hundreds, and even thousands, of ovules in one ovary, each of which receives at least one pollen-tube, in some cases more.

Even when it has taken the first turn downwards in the right direction there is plenty of room-either on its way down the pistil stalk or when it reaches the ovary-for the tube to go astray. But instead of doing so it makes unerringly for its mark, and we can only conclude that some definite arrangements exist by which it is directed into, and kept in, the right way. 


\section{XV.}

THE GOLDEN RULE FOR FLOWERS

" "GET fertilized! cross-fertilized, if you can, selffertilized if you must," that is nature's golden rule for flowers.'

We have mentioned only a few of the curious and interesting arrangements by which the pollen is in very many cases prevented from coming in contact with the ovules of its own blossom; but enough has been said to show that this self-fertilization is generally discouraged, and made in many cases either difficult or altogether impossible.

We have now to see how cross-fertilization is provided for, and by what messengers pollen is conveyed from one blossom to another. These messengers are wind, insects of many kinds, birds, and even in some instances that most unlikely of gardeners, the illreputed snail.

Plants which depend upon the wind for bringing them the needful pollen have small, inconspicuous, and generally scentless blossoms; bright colours, sweet scents, and honey, being usually confined to those plants which need the services of birds and insects. The pistil-tips or stigmas of the former are also especially 
adapted for catching and holding the grains of pollen blown upon them, for they are either divided into plumes or feathers, or are plentifully beset with hairs. Grasses and sedges are chiefly wind-fertilized; and so, too, are many trees, such as the oak, beech, hazel, birch, elm, poplar and pine, all of which blossom early in the year, often before there are any leaves to interfere with the scattering of the pollen; and they mostly bear pollen and ovules in separate blossoms, some on the same tree, some on different trees.

The pollen-bearing, or staminate blossoms of these trees grow together in large numbers, in the form of tassels or catkins, which wither and drop when their pollen is scattered and their work done.

The catkins of the hazel contain more than a hundred blossoms, having no petals, but ten or twelve stamens each. The blossoms containing the ovules grow on the same tree, but they have no petals either, and are so small as almost to escape notice, for they look like nothing but small scaly buds, with tiny crimson tufts on the top. These crimson tufts are the stigmas, outspread on purpose to catch the grains of pollen as they float by.

Pines, on the other hand, have not only no petals, but no pistil-stalks, and not even stigmas either; all that there is of the pistil being the ovary, which is scale-shaped and open, so that the pollen falls directly upon the ovules within it. As the ovules develop into seeds and grow, the scales that bear them grow also, and ripen into fir-cones.

Pollen which has to be carried by the wind is light, dry and powdery, and is produced in very large quanti- 
ties to allow for the unavoidable waste. It is carried far and wide, and the air is often filled with it, especially in the neighbourhood of forests. Masses of pinepollen are often found in America as much as three or four hundred miles away from any trees which could have produced it. Of course, where plants are dependent upon the wind for pollen, they are liable to have a great variety of it brought to them; but this does not hurt them, for unless the right kind comes it simply has no effect whatever. But as it is of great importance to these plants not to miss any chance of the right pollen, and as the wind blows at all times, night and day, they never close, many being unable to do so from want of petals, so that they are always ready to receive it.

Among the trees which are fertilized at least in part by the wind are the palms, whose blossoms are small and dull-looking, and enclosed-thousands of them together - in a sheath, something like that of the arum. But some of the palms are very strongly scented, and when the sheath opens it is a centre of attraction to a buzzing cloud of flies, small beetles and other insects.

The date-palm bears ovules and pollen on separate trees; and when date stones are planted it is found that instead of coming up half of one sort and half of the other, there are more of the fruit-bearing than of the unfruitful trees among them.

However, one pollen-bearing tree is well able to supply more than one ovule-bearing tree, and in their wild state the trees have no difficulty in obtaining all that they want. But when they are cultivated then 
they require help, though trees of both kinds grow in the same plantation. The fact is mentioned by many writers, from Pliny downwards, though without explanation; and in all the plantations part of the work consists in climbing the trees, first to collect pollen-bearing blossoms, and next to dust with them the little ovules, which are about as large as peas, and lie exposed in the centre of the other blossoms, not enclosed in an ovary. If this is not done the date crop fails.

During Napoleon's campaigns in Egypt, the natives not having much leisure to attend to husbandry, the plantations about Cairo were neglected, and although the trees blossomed as usual the eatable dates were few.

In the East dates are such an important article of food, and the failure of the crop such a serious loss, that nations at war, and desirous of inflicting as much injury as possible upon one another, were in the habit of cutting down, not all the palms indiscriminately, but those bearing pollen. On one occasion it is said that the Persians, fearing they might be injured in this way during a civil war, took the precaution of collecting the pollen from the trees, kept it in close vessels for nineteen years, and made successful use of it when peace was restored.

The Arabs are said always to keep some of the unopened sheaths containing pollen from year to year, in case of any failure in the blossoms.

It has been mentioned that pollen may often be borne long distances by the wind, and this has been exemplified in a remarkably interesting way by the case of a date-palm growing near Otranto. The palm is not a native of Italy, and though introduced, does not grow 
wild; and this specimen, being the only one of its kind in the neighbourhood, was barren for years. But at last, one year, the young dates, instead of shrivelling as usual, remained on the tree and grew to their proper size; and then it was found that a date tree had flowered that same year for the first time at Brindisi, some forty odd miles away, and had borne pollenblossoms. This pollen, therefore, had no doubt been carried by the wind to the tree at Otranto.

The case of another solitary date-tree, growing at Martinique, in the West Indies, is also interesting, though in another way. For this tree bore eatable fruit without being fertilized, but though the dates might be eaten the stones would not grow, for the seeds were imperfect, and contained no germ.

The fruit of a plant, botanically speaking, is the ripened pistil, or rather that part of the pistil which contains the ovules. Sometimes, as in the case of the various kinds of corn, it is the ripened ovules, the seeds, which are the eatable part of the fruit, the ovary in which they are contained being a mere husk. In the various gourds, on the other hand, the ovary itself grows enormously and becomes fleshy. So, too, with apples, pears, peaches, nectarines, plums and oranges, the swollen, ripened ovary containing the seed is the part best worth eating; and it has, therefore, been the gardeners' object to increase its size and improve its flavour. In the almond, the ovary remains a mere woolly skin without edible flesh; in the horse-chestnut it is a tough, thick and prickly skin, equally uneatable; in the filbert and beech-nut it is a hard shell; and in the coco-nut it consists of fibre. Whether husk, 
shell, skin, flesh or fibre, however, the whole ovary with the ripened ovules is properly the plant's fruit.

Generally speaking, the growth of the ovary, as well as of the ovules, depends upon pollen, and when the ovules are fertilized and begin to grow, the ovary begins to develop also, and not until then.

But it is not always so. Among the plants belonging to the order of Liliaceæ, which includes, besides lilies, the hyacinth, tulip, garlic, onion, and others, it is a common thing for the ovary to begin growing actively before the pollen-tubes have reached the ovules-before they are fertilized, therefore-though not before the tubes have begun to penetrate downwards through the style. In these cases the ovary seems to be excited to growth by the pollen, though not in the usual way, and before the ovules are affected.

But in many plants the ovary, and even ovules, may be fully developed, altogether without pollen; though in this case the ovules do not become seeds any more than the 'stones' of the Martinique date become seeds, and no plant can be raised from them.

Among the plants which ripen the ovary without the help of pollen are the Zante 'currant' (really a small grape), many Maltese oranges, and some kinds of apple.

While some ovules are so independent as to be able to grow to the size of seeds, and even to assume the appearance of seeds, without being fertilized, there are, on the other hand, some-as, for instance, those of the orchids-which are not even formed until the pollentubes begin to grow towards the place where they should be. The pollen in these cases not only fertilizes 


\section{The Golden Rule for Flowers}

them, but, though still at a distance, is the means of bringing them into being.

Of course, as pollen is so light, and easily blown about, many plants may at times be fertilized by the wind, besides those which are especially dependent upon it. Not many, one would suppose, are fertilized by water; yet there are one or two instances of this too curious to be passed over.

One of these is that of a small water-plant, nearly related to the duckweeds, which bears two blossoms enclosed together in a boat-shaped sheath, which floats upon the water. In the upper part of the sheath is a perfect pistil, with its ovary, short stalk, and stigma; in the lower part are the anthers containing pollen, which cannot by any possibility reach the stigma unless rain happens to fall when it is ready. If it does, the sheath is gradually filled with water, and the pollen is floated up till it reaches the right place.

There is a still more curious arrangement in the case of the Vallisneria, which grows in the ditches in Italy, and is well known, though not in a flowering state, in fresh-water aquariums. This plant bears its pistillate and staminate blossoms on separate roots, which, however, seem to grow near one another. The pistillate, fruit-bearing blossom grows on a long, slender stalk twisted like a corkscrew, which uncurls and raises the bud just above the surface of the water when it is about to open. The barren, staminate, or pollenbearing flowers, grow in great numbers on short, upright stalks under water; but just about the time when the other blossoms up above open and want their help, these buds loose themselves from their stalks and rise 
up like little air-bubbles, opening suddenly when they reach the surface. 'Here they float about on the water among the pistillate blossoms in such numbers that they often quite cover them, and by this means convey to them the necessary pollen. When this has been received, the corkscrew stalks, which are often as much as ten feet long, curl up as before, and the fertilized blossoms sink down again to ripen their fruit under water.

We must now, however, turn to the insects, among which bees have a foremost claim upon our attention, since none are more generally useful in carrying on the very important work of fertilization: Creeping insects are not, as a rule, useful visitors for flowers, as any grains of pollen which they may pick up by the way are liable to be brushed off again before they reach a blossom which might be benefited. But flying insects of all kinds, even to the smallest flies and midges, when once dusted with pollen, are almost sure to convey a few grains to the next blossom upon which they alight.

Pollen is of vital importance to the plants themselves, besides serving as food to bees and other insects; but nectar, so far as appears, is of no use to the plant except as serving to attract useful visitors; and the same may be said of sweet scents and brightly-coloured petals. All these are, in fact, the one, baits, the other, signals, which the plant puts forth to make known to those who understand the language where pollen and nectar may be found.

'Good entertainment for bees and butterflies' is what the bright colours mean; and where, as is often 
the case, the nectar is concealed in some deep and safe recess where wet cannot injure it, many flowers have lines or dots upon some of their petals to point out where it may be found, and so save their visitors' time.

Many bees have a regular pollen-brush of thick hairs under their tails; with which they sweep up the grains; and even when their object is nectar, not pollen, they are almost sure to carry off a few grains by brushing against the anthers of the blossom they are visiting. For all bees are more or less covered with hairs, some of which, being webbed, are especially adapted for holding the pollen-grains; while the grains themselves cling all the better for the spines and hairs with which they are often beset.

Small insects are useful for fertilizing small flowers, but they may light upon a large flower, creep in, and even rob it of nectar, without coming into contact with the pollen at all, which is almost impossible in the case of the larger species of bees, with their hairy bodies. The bee, too, has another recommendation : it has to visit many flowers before its crop is filled with nectar, and both hive-bees and humble-bees, especially the latter, seem generally, though not invariably, to confine their visits to one kind of flower on each journey-a very important matter, as, pollen of different sorts would in most cases be useless.

Of course, the bee may, and does, convey pollen from blossom to blossom of the same plant, which may produce self-fertilization of a sort; but when it has visited all the blossoms on one plant, and flies off to another, the first blossoms visited there must needs 


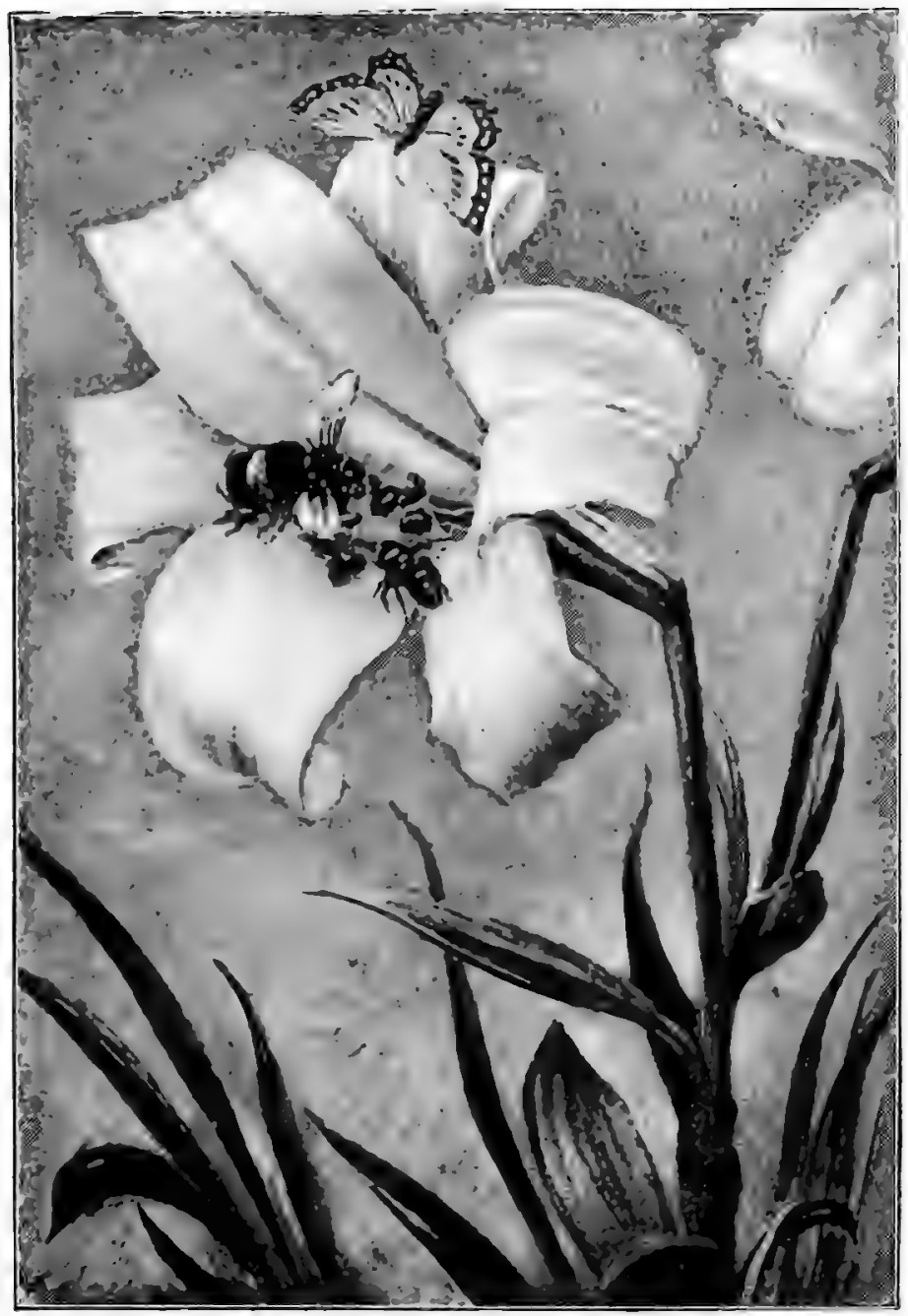



stand a good chance of receiving pollen from the last of the former.

That the work thus done by bees is in many cases absolutely indispensable there is ample proof, though we may not always recognise it.

The bean-crop failed in Nicaragua just for lack of the right sort of bee ; and often when the young gooseberries, or what should be gooseberries, wither and drop in early spring, instead of swelling as they ought to do, it is not so much because they have been nipped by the frost as that the frost has kept the bees at home. For the pollen and pistils of the gooseberry-blossoms ripen at different times, so that the one must be brought to the other if the ovules are to be fertilized; and if this is not done, neither they nor the berry containing them can grow to their proper size.

One year there was a remarkable scarcity of hollyberries in different parts of the country, which some people thought was accounted for by the cold weather in the early part of the year. But the holly is a very hardy shrub, and grows in Norway as far north as $62^{\circ}$, so that it was not likely to have suffered from an English spring. On the other hand, bees were remarkably rare that season; and, as the holly grows its stamens and pistils mostly on different plants, the dearth of berries was doubtless owing to the absence of bees.

For, though holly-blossoms are insignificant, they are fertilized chiefly by bees, and not by wind, pollen having been observed by Mr. Darwin on many pistiltips, which must have been brought from a tree sixty yards away, and could not have been conveyed 
by the wind, since it was blowing in the wrong direction.

The year that the holly-berries failed, the crop of clover-seed failed also in some parts, and no doubt from the same cause. For though some clovers manage to fertilize themselves more or less, there is a very marked difference in the quantiry of seed borne by the plants, according as they are kept covered, and out of the way of insects, or not.

A hundred heads of common red clover bear about 2,720 seeds among them; but a hundred heads covered with a net on one occasion, to keep off the bees, had not one single seed. This common red clover has a tube, too long to be sucked by the hive-bee until it has been mown, when the second crop of blossoms are said to be rather smaller, and its first crop is dependent on the humble-bee. A very slight difference in length makes just all the difference as to the species of bee which is able to extract nectar from the blossom. The brilliant crimson-clover is frequented by the hive-bee, its tube being shorter than that of the common red kind.

Strawberry plants are altogether dependent upon bees for the perfecting of their fruit, even where pollen and ovules are produced in the same blossoms. In one species of strawberry, the true Hautbois, they are borne by different plants; and in the great marketgardens of America, where this is grown, it is usual to plant one row of barren plants to every three rows of fertile ones, leaving the bees to do the rest.

A great deal has to be done to ensure the thorough fertilization of the strawberry-ovules, for there are 
from a hundred to three hundred in each fertile blossom, and there are an equal number of pistils. The pistils are set upon a cone-shaped receptacle in the centre of the blossom; each one contains in its ovary a single ovule, and the ovary and ovule ripening together, develop into a tiny nut, which is the fruit properly speaking.

As the nuts grow, the conical receptacle on which they are set grows too, and becomes soft, fleshy and sweet, forming what we erroneously call the 'berry.'

But if the 'berry' is to grow properly, every one of the pistils must receive a few grains of pollen, and if any are left out, the ovules belonging to them do not grow, and the part of the receptacle which surrounds them does not grow either, but remains hard. The hard spots sometimes found in strawberries, with a number of little 'seeds' crowded together, are due simply to the fact that the ovules have not been fertilized, and have withered instead of growing.

So, too, with the raspberry. Each one of the sixty or seventy little fruits composing the 'berry' depends upon pollen for the power of developing, not only its seed, but also the sweet, juicy envelope surrounding each seed. Towards the end of the season these often fail and wither, because the bees are either dying off, or do not care to come out unless the weather is tempting.

Then again with apples : one may often see an apple which is deformed, having grown on one side; and the reason here, too, is similar.

The calyx of the apple-blossom is a tube which spreads out at the top into five leaf-like divisions. 
Inside the tube, and joined to it, are the ovaries, which together form the horny core. When the stigmas are all properly dusted with pollen, each ovary, with its two pips, begins to grow; but, if nothing else grew, there would be no apple, only a horny seed-ressel, the only eatable part of which would be the seeds. But the calyx enclosing the core grows too, and so does the top of the stalk from which it springs; and it is these which together form the apple.

If, however, one of the stigmas be by chance left without pollen, then the ovary belonging to it, with its two pips and the part of the calyx next to it, does not grow, and the apple is misshapen.

There is a French apple called the S. Valery apple, which is remarkable for having a double calyx and a double core, with ten divisions, but no petals, and only imperfect stamens, which produce no pollen. This has to come, therefore, from different varieties, and it is a regular custom for the girls of S. Valery to go to the orchards in the spring, taking pollen from various other apple-trees, to, as they say, ' make their apples.' Each marks with ribbons her own fruit, and the different pollen produces apples of different flavour, colour and size, according to the variety of apple from which the pollen has been taken.

Occasionally one hears of an apple-tree which indulges in the freak of bearing fruit, some of which is of the ordinary shape, and some pear-shaped, both sorts growing on the same twigs. In this case one must suppose that the bees have been less particular than usual, and have dusted the pistil-tips with pearpollen. So, too, an orange blossom crossed with 
pollen from a lemon will bear fruit which is partly orange, partly lemon, with peel partly of the one, partly of the other.

Among the many plants visited by bees, large or small, are the foxglove, mallow, and campanula, all of which, though they grow pistils and stamens together, ripen them at different times. Anyone not knowing this, and examining a campanula blossom, would be puzzled to know what could have become of the stamens, for when the flower opens they have generally vanished; the pollen is there still, however, having been discharged upon the stalk of the pistil before the bud opened, after which the stamens shrivelled away. It is caught and held by the hairs with which the stalk of the pistil is clothed, apparently for the very purpose of holding it until the bees come and carry it off. When the pollen is gone, the tip of the pistil unfolds from three to five spreading branches which no pollen can reach while they remain folded; and then, back come the bees, this time in search of nectar, but bringing with them grains of pollen in abundance from other flowers.

Some pistils, as has been said, are actually poisoned, and others unaffected by the pollen of their own surrounding stamens. But there are others which carry their likes and dislikes a point further still, and require pollen, not merely from the blossoms of another plant, but from blossoms whose stamens grow at exactly the right height; and if it comes from stamens too short, or too long, they can make little if any use of it.

There is, for instance, the Great Purple Loosestrife, whose tall, handsome spikes of blossom light up the 
river banks. The pistils and stamens of this plant are of three different sizes, but they correspond exactly in height, long pistils with long stamens, short with short, and middle-sized with middle-sized. The long stamens have emerald green pollen, the others yellow; and the grains vary in size with the length of the stamens, the longer the stamens the larger the grains; for the larger grains are destined for the longer pistils, and have, of course, to send out longer tubes in order to reach the ovules.

A bee entering a blossom in search of honey is dusted with pollen on different parts of its body, according to the height of the stamens, and when it flies off to the blossoms of another plant, if the spots of dust come in contact with pistil-tips of the proper height they may be caught and kept.

The red Oxalis is another of the plants having pistils and stamens of three sizes, and a large field in Brazil containing many acres of this plant yielded not a single seed, because, though pollen and insects were both plentiful, all the plants chanced to be of the same 'form,' as it is called: all had long pistils and short stamens, or vice versâ, and the pollen was of no use. Other plants possess similar peculiarities, but we will mention one which all can examine for themselvesthe common yellow primrose.

The blossom of the primrose is a long tube flattened out at the top into five divisions. If we look at a bunch of primroses gathered from different plants, we see at once that all are not alike. In some the pistil, with a knob like a pin's head, stands up just out of the tube; in others no pistil is visible, but in its place, 
just at the same height, are five stamens standing up like teeth, the stalks being so very short that they are almost all anther. In spite of their shortness, however, the stamens are on a level with the long pistil of the other blossom, for they are attached to the flower tube; and for the long pistil their pollen is intended. The pollen grains of the stamens which grow with the long pistil-but out of sight, half-way down the tubeare intended for the short pistil, whose knob is just at their own level, and, accordingly, they are smaller.

All flowers which vary in this way, all which are distinguished by colour, scent, size, or irregularity of shape, are mainly indebted for fertilization to insects. This is the case with all bell-shaped and tubular flowers, also with the snap-dragon and foxgloves, and with the dead nettles, lavender, thyme, and all blossom of similar shape to these, besides many others. In some the shapes of the blossom and of the insect by which it is fertilized are as beautifully and exactly fitted one to the other as the lock is to the key,' and in others there are endless different devices for securing that the visitor shall not depart without doing some service in return for the pollen or nectar which it has consumed or carried off.

In the common stinging nettle the four stamens lie folded down flat until they are touched, when they spring suddenly up and scatter their pollen; a needle inserted in the throat of the common purple lucerne causes two stamens instantly to start up like a jack-inthe-box, the anthers at the same time exploding and discharging their dust. A similar explosion takes place in the flowers of the whin and in many others. 
In one plant the anthers act like a pair of bellows, and on being touched blow their dust out upon the insect; in another-the Kalmia, or American mountain-laurel, the stamens rise up from the petals on which they usually lie flat, and close round the insect, clasping it and impressing their pollen upon its body.

But the various arrangements are so numerous that it is impossible to do more here than give the merest outline-sketch of them, and for fuller particulars the reader must be referred elsewhere.

We have confined our attention hitherto chiefly to bees, because they are the most generally useful of insects, and few flowers seem to come amiss to them if only they can reach the nectar. But there are just a few flowers which they actually avoid. Bees of all kinds, for instance, shun the Crown-imperial, though it blossoms in March and April, when bee food is not plentiful. Gilbert White noticed a small bird like a white-throat running up the stems of this plant and plunging its head into the bells in search of nectar, so it may be that it is fertilized in this way, for it certainly sets seed.

Other flowers disliked by bees are the passion-flower and dahlia-which seem to stupefy and often kill them, and, above all, the oleander, whose nectar is fatal. A traveller in Hungary and Dalmatia, where the oleander abounds, could not remember ever to have seen bee, moth or butterfly visiting the blossoms. And yet their bright rose-coloured petals seem to say, in the language of flowers, that they need the help of insects, and those, too, of a high order.

For colours have much meaning in the flower lan- 


\section{The Golden Rule for Flowers}

guage, and show to some considerable extent what kind of insects are wanted for the blossoms which display them.

White, for instance, serves to attract insects of all sorts ; but bright yellow seems to be especially favoured by beetles, and blue by bees, though they do not, of course, confine themselves to flowers of this or any colour. What a flower lacks in colour may often be more than made up for by its sweet scent and abounding nectar. The dull pink sedum, for instance, which blossoms in the autumn, attracts a swarm of humblebees and butterflies; though, as its flowers are flat and tubeless, the nectar is open to all comers, and bees are not necessary to it.

Yellow is said to attract insects of the lowliest kind; white, those a little higher in the scale; and pink, red, lilac, purple, blue, rank higher and higher as to the insects which they attract, that very superior insect, the bee, being, as already said, especially pleased with blue.

It is the fashion at present to say that the bright. colours and sweet scents of flowers exist solely for the plant's own benefit, as the means of drawing to it the insects which carry pollen from one blossom to another. Nevertheless, man is gratified abundantly; and if this theory be correct, he may at least congratulate himself on the fact that he and the insectworld are of one mind as to what is agreeable and attractive.

But are he and they altogether of one mind ? The butterfly will hover about a lavender-bush, attracted by the perfume, and so far man shares its taste; but it will also go and drink daintily at a drain, and, for any- 
thing that appears to the contrary, an ill scent may be as pleasant to it as a sweet one.

Ill-smelling flowers, as well as sweet ones, have their admirers, and are certainly not especially avoided by insects ; and flies will regale themselves upon honey or filth, with apparently equal satisfaction. Ill-smelling flowers are, however, comparatively very few ; and as their colours are generally deep yellow, orange, brownred, or brown, we may conclude that they are not frequented by such high-class insects as bees. 


\section{XVI.}

\section{GUESTS WELCOME AND UNWELCOME}

BeEs do more, on the whole, for the fertilization of flowers than any other insects; but, though plentiful throughout the plains of Europe, they become fewer and fewer as the traveller ascends the Alps; and in the Tyrol, at a height of from 6,000 to 9,000 feet, he may see hardly so much as a bee a day, and that of the ' humble' species only.

There is, it is true, the Ligurian, or yellow Alp-bee, which is a mountain insect, and thrives in some of the southern cantons of Switzerland up to a height of 4,500 feet ; but still, the higher one goes the fewer bees there are of any kind; and though there are many beetles and flies, and very many moths and butterflies, there are, on the whole, fewer insects of all kinds in these higher regions; and in the highest, bees are almost entirely absent.

Yet the flowers of the high Alps are so intensely bright in colour that it is pretty certain they must be visited by insects of some sort; and, besides being of such vivid colours, the flowers here are made still more striking by being massed together in large beds, instead of being scattered here and there. For the fewer the 
insects, the more needful it is to economize their time and labour, and to avoid the risk, which solitary plants would run, of being overlooked altogether. Here, as elsewhere, "union is strength'; and the butterfly must be blind indeed which could fail to notice these masses of brilliant colour.

For the chief flower-visitors in these Alpine regions are moths and butterflies, together with flies and beetles; and it is curious to see how flowers which are visited by bees in the plains and lower mountainregions are modified to suit moths or butterflies when they come up higher.

Of the many orchids, for instance, which grow in the plains, all but very few-four or five, perhaps-are visited by bees ; but in the Alps, out of five species, all but one or two are dependent upon butterflies or moths.

Flowers change in colour when they migrate to these higher regions, on purpose to attract more notice Our pale yellow primrose is fertilized almost entirely by moths, but it might be overlooked among the bright flowers of the Alps if it did not dress more gaily there, so it wears brilliant pink and magenta. The wild pinks also, which straggle about here and there in the lowlands, sure not to escape notice among the many visitors constantly flitting to and fro, here take the precaution of growing larger blossoms, besides massing themselves together in such a way as to catch the eye of any wandering insect.

Large masses, large blossoms, brilliant coloursthese are the means by which the fewer insects of the high Alps are guided without loss of time to the place where they are wanted; and flowers which might never 
be found out if they grew separately are ensured a oainst neglect by thus growing in company.

But, many and beautiful as are the moths and butterflies of the mountains, one must go to the tropics to see them in their full glory of numbers, size, and colouring.

Of all parts of the world, South America is richest in butterflies, and the richest part of South America is the region of the Amazons; where, also, the broad belt of forest which surrounds the land-surface of the earth almost continuously at the equator is denser than anywhere else, and swarms with insects of many kinds.

There are some $r, 200$ species of butterflies in this region; but these gay insects do not care for the solemn depths of the forest, where they find little or no entertainment, and they are chiefly to be seen in the more or less open paths, where there is more light, and where, consequently, more flowers are to be found.

Here large blue butterflies, and many others, fly along for miles, and always return if driven into the forest. For this is gloomy and even musty, like a cavern; the damp ground is not covered by herbage, there is little beauty or brilliancy of colouring in the trees, and flowers are rare.

The fact is that, according to the German proverb, 'one cannot see the forest for the trees.' They are so crowded together, and they run up to such a height, that there is little to be seen but trunks, canopied by a mass of foliage so dark and dense that the sun is quite powerless to penetrate it.

Many trees never blossom until they are a hundred feet high, and it is only when a shower of bright petals 
falls from above that there is any sign of what is going on overhead, or of the beauty, displayed to insects only, outside the dark canopy. Beneath it the world is dank, dull, gloomy, unrelieved by a ray of light; but what a different world it is above! Here the sun is in full blaze, and bees in swarms are humming cheerily over the magnificent banquet of flowers spread for them.

Bees do not like gloom, or even the chequered shade which contents the butterflies, and they would have missed the feast if the flowers had grown down below.

It is by the roadside, on the margin of the forest, in the paths, and along the river-banks that the real beauty of tropical vegetation is to be seen; for here are bushes, shrubs, trees of every height, adorned with festoons of creepers, and brilliant with bright flowers and gorgeous butterflies.

Even here, however, there is nothing to surpass such masses of glorious colour as are to be seen on our heathery moors or gorse-covered commons; and though tropical blossoms are undoubtedly splendid, they are not as common as one is apt to fancy, and they generally last but a short time, beginning to fall almost at once.

Bees abound in this region, but they keep in the sun, among the blossoms borne high up overhead; and the butterflies float lazily along the paths which are chequered with light and shade, but they keep for the most part near the ground. If the smaller trees, therefore, followed the example of the giants of the forest, and bore their blossoms on their tops, they would be in danger of missing both classes of visitors. The bees would know nothing about them down in the shade, 
and the butterflies would not rise high enough to find them.

Under these circumstances, therefore, many trees, such as the custard-apple, bear their blossom on the trunks or larger branches, where moths and butterflies can find them. The cacao is another which does so, and when the large yellow fruit is ripe, the trunks of some of the smaller trees are hardly to be seen, so thickly'does it cover them.

But, much as these insects do both in the tropics and in the mountains, it must not be supposed that their services could be dispensed with even in temperate latitudes and in the plains. Quite the contrary. Most of the European orchids are fertilized by bees, but just a few species cannot get on without the help of moths. There is a large sphinx-moth which carries pollen to and from one species of orchid in a very curious way-on its

eyes. The pollen of this flower Pollen mass of an grows in two masses, each perched

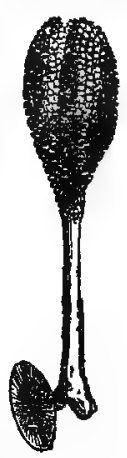
upon a stalk which passes through its centre, and to which the grains are united. At the base of the stalks are tiny button-shaped discs, one on each side of the stigma, face to face. When the moth presses its head into the centre of the flower, the discs come into contact with its eyes, and, being very sticky, they adhere so firmly that the whole thing is dragged out -stalk, pollen, and all. A very strange object one of these moths is when it is thus adorned, for the stalks, with their lumps of pollen at the end, at first stand out 
straight, like horns in the wrong place. In a minute or so, however, they contract and bend down, and then the pollen is in exactly the right position to be caught and held by the stigma of the next blossom of the same species, which the insect must, one would imagine, be in haste to enter if it knows how it may get rid of its undesirable appendages.

Orchid-blossoms remain in full beauty a long time, whether cut or not, as long as they are not fertilized; but when insects are allowed to get at them, they fade rapidly and go to seed.

Among the flowers specially attractive to moths in Europe are the valerian, petunia, phlox, hop, nettle, pink, ivy, clematis, pansy, jessamine, and honeysuckle, the last being frequented, according to Gilbert White, by a large sphinx-moth, which appears after dusk, and feeds, like the humming-bird, on the wing, scarcely ever settling, and making a humming noise with its wings.

The jessamine is probably fertilized by the hawkmoth, which hovers in like manner; but jessamine-seed is rare in England, for hawk-moths are rare too. But the want of hawk-moths may not be the sole reason for the scarcity of seed. The humble-bees are also in some measure to blame, for they come to the blossoms in search of nectar, and finding no perch upon which they can stand to suck in the proper way-the only way to benefit the flower-they get what they want by gnawing through the tube of the corolla, which soon drops in consequence.

Flowers which open at night are of course especially dependent upon night-flying moths; and as colours would not be seen, they are generally white or pale 
yellow, and have no lines to show where the nectar is, for these also would not be visible; but they are often so sweet as to be scented from afar. The large white bindweed, though it opens by day, remains open at night, when the moon shines, but not otherwise, to receive the visits of moths.

Wherever, in any part of the world, there is a dearth of bright-coloured flowers, there, as a rule, there is a scarcity of insects, and vice versâ, for, where insects are wanting, there the flowers fertilized by them cannot of course flourish.

The scarcity of both these is very conspicuous in the Galapagos islands, situated on the equator, some 700 miles west of South America. In Juan Fernandez also, which lies about 400 miles off Chili, ferns form the larger part of the vegetation, as they do in most of the South Sea islands. But there is no such total absence of showy blossoms in Juan Fernandez as in the Galapagos. One shrub which flourishes there bears snowy blossoms, like those of the magnolia; another, also plentiful, has dark blue flowers; and besides these, there are large patches of a white, lily-like bulb, and there are two conspicuous yellow flowers as well.

Yet Juan Fernande $z$ is poor in insects. It has but one butterfly, and that is rare; there are only four species of moths, and no bees at all, but some which are very minute and of no more use to large blossoms than the flies, of which there are twenty species.

But the poverty of the insect-life is made up for by the presence of humming-birds, which are so abundant that there are one or two in every shrub; and these when killed are usually found with the front of their heads covered with pollen. 
The group of honey-eating birds is so immense, both in the islands of the Pacific, Australia, America-North and South-the Moluccas, etc., that there can be no doubt as to the large share they take in conveying pollen from one flower to another.

The ruby-throated humming-bird frequents lilacs, phloxes, portulaccas, morning glories, roses, honeysuckles, snap-dragons, fuchsias, and many other flowers; and in dry weather, before the spring begins, it will even enter greenhouses and suck the fuchsias there, which it does more rapidly than the honey-bee.

The Portuguese name for the humming-bird is Beija Flor, 'Kiss-flower'; but the little creature is not so ethereal in its habits as its appearance and poetical name have led people to suppose. It does ' kiss' the flowers, but with a view to something more substantial than nectar merely, though that may be all very well as an addition to its food.

Many a humming-bird has been starved to death in captivity, owing to the mistaken notion that honey, or sugar-and-water, was all that it needed; whereas these living, flashing jewels possess tongues which are exactly adapted for picking up insects; and insects are their principal food, though they take nectar as well.

The humming-bird's tongue is long, and can be stretched out far beyond its bill; it is very flexible, and being cleft in two it can be opened and shut at will, ' like a delicate, pliable pair of forceps.'

The humming-bird is, indeed, nearly related to the swift, and its chief diet consists of the small insects which are seldom wanting in the long-throated blossoms of the tropics. The sheaths of the arums and their kindred are generally full of insects too; so 
are those of the palms, and the 'pitchers' with which many plants are furnished likewise afford insects in abundance.

Whether the birds go for nectar or for insects, it is all the same so far as the plant is concerned, for in neither case can they help coming in contact with the stamens and getting their heads and beaks dusted with pollen.

The Marcgravia, for instance, is a plant which grows a circle of tlowers like the lamps of an inverted candelabrum. From the centre of to's circle hang a number of pitchers filled with a sweet, $\mathrm{b}$ liquid, which attracts swarms of insects. These, in their turn, attract, not only humming-birds, but a variety of others which cannot capture their prey without brushing against the hanging stamens of the bell-flowers.

In Labuan large flocks of starlings are similarly attracted to a flower with brilliant scarlet blossoms; and in the Malay and Molucca Islands much pollencarrying is done by the little brush-tongued lories, small parrots, with unparrot-like tongues, which are long, flexible, moist and hairy, and thus well adapted for collecting honey from the tubes of the many large blossoms which they visit.

Bees, butterflies, moths, birds-these are the most conspicuous of the 'under-gardeners,' to whom is entrusted the important work of fertilization; but there are others equally useful in their way, though their sphere of operations is less extensive. Even the wasps do something, for, in the absence of fruit, they suck flowers, as Gilbert White remarked, especially those of the ivy and small umbelliferous flowers; they are especially attracted by the red and yellow blossoms of 
the 'Poker-plant' (Tritoma), which blossoms in the late summer, and may be seen creeping quite into the tubes; and they are also said to fertilize the dahlia, which is shunned by bees.

' Where the bee sucks honey the wasp sucks poison,' is a common saying, and as devoid of foundation as such sayings often are. It is a libel on the wasp, and too flattering for the bee; for if the bee does suck and store honey, which last the wasp does not pretend to do, it also secretes poison, and its sting is generally considered much the worse of the two!

To small, flat flowers, whose nectar lies so near the surface as to require little probing for, beetles and small flies are almost as useful as bees, and may be seen in crowds on such little blossoms as those of the wild carrot, and others of the same family which grow together in flat heads or umbels. Even the water-side midges do their part among the small flowers of the river banks.

All sorts of little flies, gnats and midges are attracted also to the arums, some by the prospect of pollen and nectar, others, as the carrion-flies, by the flesh-like appearance and smell of many foreign species, on which they even lay their eggs, supposing that their grubs will be well fed; another illustration of what was said before, that if they existed solely for the purpose of attracting insects, all flower scents might just as well be what human beings consider disagreeable.

The arrangements of the arum family are so curious as to be worth a little special attention. We most of us know the so-called 'arum-lily,' with its white flower with the golden sceptre. The flowers of the arum are 
contained in a sheath, properly called a spathe, which is snowy white in the 'arum-lily " and greenish in the wild one. The real blossoms are clustered round the sceptre, or spadix, which is golden in the one, and purplish, or brown, in the other.

In some of the southern and foreign arums the lower part of the sheath, which is enlarged and contains the blossoms, is shut off by a ring of longish hairs which point downwards and allow the visitors to enter easily, but effectually prevent their coming out again until they have done what is wanted of them. The lower part of the spadix generally bears the flowers with pistils, those with stamens being arranged in a ring a little above. The lower blossoms are ready first, and to them the insects, or some of them, bring pollen from other flowers of the same species. But it is not enough for them to bring pollen, they must also carry some away, and for this purpose they must be kept until the anthers burst.

Meanwhile their prison is made very comfortable for them : it is pleasantly scented-we are not speaking now of the fleshy species-it is also rarmed and provided with nectar. When the anthers burst, pollen is added to the feast, and some of the captives devour it so greedily as to be quite intoxicated. Enough, however, remains adhering to their legs and bodies to make them acceptable visitors elsewhere, and, as soon as the pollen is shed and there is no further reason for keeping them, the hairs which prevented their escape wither and die, and they are free to depart-generally, but not always. The hairy arum of the South is said to show her gratitude for the services rendered to her by her visitors, carrion-flies, in a remarkable manner. 
She catches and devours many, digesting them by means of the sticky hairs which cover the inside of the sheath.

Most of the arums of the temperate zones blossom early in the year, when the nights are still chilly enough to make the prospect of a warm lodging attractive.

Blossoms breathe more rapidly than leaves, and are always therefore a little the warmer. Buds just opening breathe so fast, if they are large, like those of a cucumber, that when they are isolated under a glass containing a tiny thermometer, the mercury may be seen to rise sometimes nearly two degrees.

Many blossoms heat so much more than this, however, that the difference may be felt as well as seen. This is the case with the arums, whose so-called blossom is really an assemblage of many blossoms. In the common wild arum, 'lords and ladies,' the temperature rises several degrees, but in the heart-leaved arum of the Isle of Bourbon the temperature of the sceptre, or spadix, has been known to rise to $95^{\circ} \mathrm{F}$., and nearly $102^{\circ} \mathrm{F}$., and that, too, when the temperature of the air was only $59^{\circ} \mathrm{F}$.

But the common Italian arum outdoes even its tropical cousin, and its spadix becomes hotter than a hot bath, its temperature being nearly $I 10^{\circ} \mathrm{F}$.

Arums are especially marsh-plants, and, though one does not naturally associate the idea of warmth with such cold creatures as snails, it seems that it is these which are chiefly attracted to the arums of south Europe, and, no doubt, of other parts of the world.

One of the foreign arums grown in hot-houses for the sake of their handsome foliage was observed one 
day at noon to begin to blossom and grow warm at the same time, its temperature rising beyond $100^{\circ} \mathrm{F}$. Suddenly it gave out a strong fragrant scent, between that of cinnamon and musk, which filled the whole house, and would no doubt have been a well-understood signal in its own country, telling the small marsh-snails that their night quarters were ready. These would climb the stalk and find entrance by a narrow opening at the base of the sheath, which would soon after close upon them. Twenty-four hours later the scent and warmth have much diminished, but then the anthers open and drop down their pollen, not in separate grains, but in chains or tassels of grains adhering together, as much as an inch long, and far too bulky therefore to be carried away by insects. On coming in contact with the moist bodies of the snails, however, the chains separate into grains, which adhere and are borne away when the guests move on.

And they are obliged to move on soon after the pollen has fallen or else they would be suffocated; for the blossoms have been breathing vigorously in a confined space, and so much carbon has been burnt, and so much carbon-dioxide produced, that the bulb of the sheath is completely filled with it, and a glowing match held within is extinguished. Such visitors as stay too long are therefore safely suffocated, and thus prevented from eating the young fruit, which they would otherwise do without fail.

The prudent snails, however, having enjoyed their warm bed and nectar, do not outstay their welcome; but, when these passing pleasures have come to an end, they linger no longer, make the best of their way up the sheath and down the long stem, and then 
proceed without delay to climb some other plant whose blossoms are beginning to give fragrant notice that another pleasant guest-chamber is ready for their reception. Thanks to this diligence, therefore, pollen is brought to the pistils, as soon as they are ready for it, by the 'fastest snail-express.'

Hitherto we have confined our attention to the welcome guests; but there are unwelcome ones also, and the very snails last considered have two sides to their character. Indeed, the beneficent side is not the one with which we are familiar, being rather a recent discovery, while their mischievous propensities are well and widely known. Even the arums which welcome them as pollen-carriers need some sort of protection against them. They have to be tempted to undertake what to them is really an immense journey, by special attractions, otherwise, being voracious eaters, they would simply begin to devour the first leaf they came across. Then, when they have started, all loitering by the way is sternly discouraged, for arum-leaves are acid, and even poisonous; so there is no temptation to make a meal of them.

Useful as they are to arums and arum-like plants, they are not generally desirable as visitors, and are not often found in flowers, bristles and prickles being enough to turn them back at once. No wingless visitors are generally welcome, for they crawl slowly, lose pollen by the way, by getting it rubbed off them, and are usually so indiscriminate in their tastes, that they go as readily to one blossom as another, and it is quite a chance what pollen, if any, they may bring with them. 
It is, of course, not to the plant's interest that its pollen and nectar should be taken by insects which plunder without making payment in return, as it is thereby robbed of its means of attracting other and more useful insects. But the useless ones are just as fond of nectar as the useful, just as quick, too, to find it out, wherever it may be hidden, so that many devices are needed to baffle these unwelcome guests.

Human beings can, it is said, detect less than the twenty-millionth part of a grain of musk; but in keenness of scent they are far surpassed by the insect world.

Where is the man who can detect any difference, by smell or otherwise, between cane-sugar and beetsugar, when the latter is properly refined?-not, of course, such as one meets with in continental hotels. Yet the bees know well, for if the choice be given them, they will take the cane and leave the beet.

And ants are not only as fond of sweets as bees, but will find them out from an immense distance. They have been known to make their way up from the garden to the second story of a house, by means of an outside bell-wire, all for the sake of some dried fruit which they had scented out. They are sure, therefore, to know where nectar may be had, as well as the bees themselves; and yet, what with their crawling, and their tidy habit of constantly cleaning themselves, and their hard coats, which are not suited for carrying pollen, they are some of the least welcome guests that a flower can have.

When the ants do get a chance, they make the most of it, and swarm in greedily; but on the whole they are pretty well kept out, now by one means, now by another. 
The snap-dragon, for instance, keeps her mouth so firmly closed that none but the strong humble-bee can force its way in, until, that is, the necessary pollen has been brought. But then, when the seed is made sure, and the ants can do no harm, the lips are unclosed, and they are generously admitted to what remains of the feast, an opportunity of which they do not fail to make use.

Ants, like other wingless insects, prefer to avoid the dew, and so are not astir very early. Some flowers, therefore, unfold for only a short time during the first hours of the morning and close again by 9 a.m.; and in all probability there is a close connection between the times when flowers open and close, and the hours when their friends and enemies are abroad.

Plants such as the teasel keep off the ants by means of the basins formed by their leaves, which catch the dew as it trickles down their stems, and keep it so effectually as to be seldom empty while the plant is in blossom. Water is completely baffling to ants, and if placed on the stem of a plant thus protected, they run helplessly up and down, and then drop to the ground.

Stickiness, too, of all kinds, is their abhorrence, and is often fatal to them, whether in the form of sticky hairs or sticky juice. The lettuce is one of many plants furnished with a milky juice, which is especially abundant near the flowers. If an ant crawls up the stem, its hooked feet are so sharp as to cut through the outer skin, and the juice which at once oozes out hardens rapidly, gluing it to the spot, while the little creature's frantic efforts to clean itself only make matters worse, and it seldom succeeds in escaping. 
Many of the plants belonging to the order which contains the catch-flies, campions and pinks, are provided with rings of sticky hairs, and as many as sixty-four small insects have been found at once on one flower-stalk of the red German catch-fly. One can imagine how little nectar would have been left to attract profitable insects, if these sixty-four had been allowed to have their way. Ants are usually very wary in their manner of proceeding, and feel their way carefully up the stalk until they reach the sticky ring, whereupon they generally turn round and come down again; but if they do venture to proceed they are surely lost.

Stickiness is no impediment to slugs and snails, however, for they overcome it by covering it with their own slime. What they do mind are bristles and prickles, which the armour-clad ant can afford to despise.

Pricklets, hairs, and fringes inside the blossom, serve often a double purpose, for they both keep out unwelcome visitors and make the welcome ones reach the nectar by the right way. Thus, insects wanting to get at the honey in the spur of the garden-nasturtium, are obliged to climb over the fringe on one of its three lower petals, and this they cannot do without coming in contact with anthers or pistil, which they might otherwise pass untouched.

Plants sometimes need protection against even their best friends the bees, for some of these, in spite of their many good qualities, have a way of trying to reach the nectar by other than the right way-by house-breaking, in fact, instead of by the front-door; and others, though willing enough to come in properly, 


\section{Guests Welcome and Unwelcome}

are too small to be serviceable to large blossoms. We have already mentioned how humble-bees bite through the tube of the jessamine, because they find nothing to stand upon while they suck the blossom. But as the jessamine is a foreign flower, this may be thought excusable enough, as there are few insects here able to reach the nectar in the right way.

But some bees really seem to be lazily inclined to save time and trouble, for they always bite a hole in the columbine, among others.

The bladder campion, however, successfully frustrates any such designs by growing a calyx which is so inflated that no bee's proboscis is long enough to reach the nectar by means of a hole made in it. Others have calyxes so hard and tough that even humble-bees and ants are baffled by them.

But, then, the little bees-where big bees can enter, why not little ones? The foxglove, for instance, gapes widely open; and as stamens and pistil lie close under the upper side of the blossom, they are quite out of the way of the small bee, which would pass in and out without touching them, if it were allowed to find entrance at all. But an observer who watched the flowers carefully throughout a season in North Wales, where they especially abound, saw many small bees make the attempt but only one succeed the whole time. It looks easy enough, but the upper part of the blossom is so smooth as to be actually slippery, and affords no foothold; and the lower part is beset with stiff hairs, which are very embarrassing to smaller insects, though the humble-bee uses them as rests for her feet and clings to them while she sucks. 
It is interesting to watch the methodical way in which a humble-bee visits and explores a spire of foxglove, always beginning with the lowest bell and working upwards; but it may not have otcurred to all of us that, if she reversed her operations, the foxglove's hope of cross-fertilization would be gone. So it is, however ; for the foxglove-blossoms not only open gradually, beginning with the lowermost, but the pollen is ripe before the pistils are ready for it; and consequently the pistils of the lower blossoms are waiting for pollen-their own being safely gonewhile the anthers of the upper blossoms are discharging it. If the bee began at the top', she would only bring to the pistils pollen from the upper blossoms on the same stalk; whereas, leaving off at the top, she carries pollen away to the lowest blossoms on the stem of another plant.

Such are a few, and only a few, of the many marvellous provisions for ensuring fertilization, for preventing self-fertilization, for promoting cross-fertilization, and for preventing the robbery of pollen and nectar by insects which would not benefit the plant; and to conclude with the words of Professor Asa Gray:

'If these structures and their operations do not argue intention, what stronger evidence of intention in nature can there possibly be? If they do, such evidences are countless, and almost every blossom brings distinct testimony to the existence and providence of a Designer and Ordainer, without whom, we may well believe, not merely a sparrow, not even a grain of pollen, may fall.' 


\section{XVII.}

SEED - SCATTERING

THE great end of a plant's life is to bear fruit. 'It is for this that roots and leaves collect nourishment, and that insects and birds are attracted to the blossoms by bright colours and the prospect of food. So entirely, indeed, is fruit-bearing the aim of the plant's life, that many plants are dry and withered by the time the fruit is ripe, having given up all their sap, their very life, to bring it to perfection. In any case, whether it last for one year or two, or many, the plant's life is devoted to making preparation for its offspring.

For this reason few wild flowers are double, as the number of petals must be increased at the expense of stamens and pistils, and without these fruit is impossible.

A cherry-tree covered with double-blossoms may be very ornamental, but the gardener grows it for its blossoms only, and does not expect fruit from it. When his object is fruit, however, he sometimes interferes in another way, which has the same result, so far as the plant is concerned; for he increases the eatable part of the fruit, in some cases, as he increases the number of the petals-at the expense of the seed. 
A plant's fruit is the ripened ovary, containing the seed; and when the seed is the part used for food, man naturally devotes his attention to that, and cares nothing for the case. From corn, for example, and from nuts, he wants the seed, not the husk or shell, and therefore he cultivates and increases the size of the seeds. But the seeds of pears, grapes, pine-apples, oranges, dates, are not what he wants; and in some of the best sorts of all these he has so cultivated the ovary, or fleshy envelope, at the expense of the seeds, that these have almost, if not quite, disappeared.

He has done much the same thing, too, with some of the best figs; only here he cares neither for seed nor ovary, but for the receptacle; for a fig may be best described as being, like a strawberry, turned outside in.

We may have seen young figs growing on the trees in plenty, but who ever-saw a fig-tree in blossom?

The first things to make their appearance on the leafless branches in spring are not buds but miniature figs. They have much the appearance of hard green buds, but are in truth stems, hollowed out, and having blossoms ranged round them inside, each pistillate blossom having its own ovary, which ripens into a minute nut-the true fruit. The stem or receptacle, therefore, is the part which becomes sweet and fleshy, and it contains within it many ovaries, just as, in the case of the strawberry, many ovaries are placed upon the receptacle. When the gardener increases the size of the receptacle, then, and diminishes or does away with the 'seeds,' he grows little if any fruit, though plenty of figs.

The fig is a tree nearly related to the mulberry, hop, hemp, and stinging-nettle, none of which bear pistils 
and stamens in the same blossom; while some, as the hop, bear them on different plants.

In the fig-tree the two kinds of blossom are borne sometimes in the same 'fig,' sometimes on separate trees. In the former case the pollen-blossoms are above and the ovule-blossoms below, and there would seem to be no difficulty about the fertilization. As we have already mentioned, fertilization is not absolutely necessary to ensure the swelling of the figs, in the case of some varieties at all events; but still many growers resort to what is called caprification, in order to ensure their crop. That is to say, they take branches of the wild fig, when its blossoms are ready, and place them over the cultivated fruit. The wild fig is very much frequented by a small insect, which deserts the wild for the cultivated fig as soon as it gets its wings. Figs are not entirely closed at the top, and through the small opening left the insect makes its way, for the purpose, probably, of laying its eggs. Whether it carries pollen from the wild fig or from the staminate blossoms to those below it in the same fig, or whether it helps the growth of the fig merely by pricking it in order to lay its eggs, seems to be a doubtful matter. But some growers consider that the insertion of an oiled straw answers the purpose equally well, and that, if left entirely to themselves, the figs often do not develop.

In England, however, where excellent figs ripen, especially on the south coast, there are certainly neither wild figs, nor the insects frequenting them, to give any assistance; nor are any artificial means resorted to. But whether the 'nuts' contain any germ or not is another question. 
Whether they receive assistance or not, however, most of the fig's blossoms produce no 'nuts,' and hence the growth of the sweet flesh must be in some degree, if not altogether, independent of them.

With many fruits, as already said, it is possible to almost or entirely do away with the seed, and still to secure, and increase the size of, its eatable part. This the gardener-can afford to do; but nature cannot, for, without seed, no offspring.

Such is the general law, the exceptions to which have been already referred to. But, even when the plant is left in a state of nature, and allowed to produce seed in abundance, it often needs further help, if its progeny are to grow up healthy, and vigorous enough to hold their own among their many competitors. The seed must be scattered.

The gardener often finds it advisable to get his seed from some little distance, the plants raised from it being distinctly-better than those grown from seed ripened in the same place. This is one reason why it is for the plant's good that its seed should be scattered; and here, of course, we mean by the 'plant,' the race, and not the individual. But there are many other reasons.

If seeds are dropped close round the parent-plant, in a confined space, they grow up in a crowd, and there is a desperate struggle for existence. Being all of the same species, they all want the same kinds of food, and none have much advantage over the rest. A few seeds may have been a trifle larger, and may produce seedlings a trifle stronger, and better able to battle for what they want; but the difference is usually slight, and the chances are that all will grow up weakly. 
Where seedlings are crowded together there must always be a struggle as to which shall survive, but it is much more severe where all are of the same sort. Where they are mixed, some will have advantages. They may be larger and stronger, or they may be better fitted for the soil and situation. Whatever the advantage may be, those possessing it will speedily overpower their less fortunate rivals, and then, having secured sufficient elbow-room, will grow up strong and healthy.

Plants of different species, when crowded together, are better off in another respect, for they do not all want precisely the same amount of the various mineral foods, and so there is more for all. For this reason it is a very usual thing to sow a grass-field with seed of different species; and the greater the variety, the heavier the crop of hay, because the plants have had a better opportunity of obtaining food.

On this account, therefore, as well as that they may have change of air, it is well for seeds that they should be scattered, or otherwise dispersed. But there are other reasons still.

Some plants need shelter, and are killed by sudden exposure. If they had no means of dispersing their seeds, not only they, the parents, but their whole progeny, might be exterminated by the removal of trees, etc. Or again, by the draining of a pond or drying up of a brook, plants needing much moisture might be killed out of a neighbourhood, if all their seeds dropped close round them, while they might continue to flourish if they were able to migrate the distance of only a few yards.

In some cases, too, the parent so exhausts the soil, 
that the children have no chance of thriving, if they grow under its shadow; and then again, if cross: fer ilization be an advantage to the plant, even where not absolutely essential, it certainly seems-from experiments made in crossing Indian corn and beans with plants grown some miles away - that crossfertilization with plants at a distance is more beneficial still, the produce being in each case very greatly augmented.

Such, then, are the strong arguments in favour of Nature's plan of scattering her seed far and wide: the plants gain change of air and change of soil; competition is less keen, cross-fertilization is promoted; and, when driven by stress of circumstances from one neighbourhood, they are able to gain a settlement in another.

By one means and another seeds are widely scattered, and there is not a bare patch of soil on railwayembankment or mountain-side which is not speedily sown.

At first sight it would seem that as plants are rooted to the soil, migration would be impossible as well for their offspring as for themselves; whereas, in reality, they are more migratory, and wander further afield than most animals, though these are free to come and go as they will.

Winds, waves, birds, beasts, fishes, and even man himself, are all pressed into the plant's service, and made to act as seed-carriers. But in some cases the plant itself acts, and acts alone, sending her seeds to quite considerable distances.

Many years ago, there was a certain bare, rocky crag near Dunkeld, which the Duke of Athole desired 
to have planted with trees, though he was quite at a loss how to accomplish it. For, as the place was simply inaccessible, no one could climb up, either to sow seeds or to plant saplings. The Duke mentioned his difficulty to Nasmyth, and he, noticing a pair of small cannon in front of the castle, ordered a number of tin canisters, filled them with suitable seeds, and fired them from the guns up the high face of the crag, where they burst, and scattered their contents in all directions. Some few years later there were trees flourishing luxuriantly in all the recesses of the cliff.

Plants cannot perhaps shoot their seeds quite so effectually as this, but in many the seed-vessels split with so much of an explosion that the seeds are discharged to distances which, at all events, remove them from the danger of being squeezed to death in a crowd. The Touch-me-not balsam is one of these. But the Sand-box tree of Barbadoes is much more energetic. Its fruit is rather like a small melon in shape, but hard and woody, and when ripe it bursts with a loud report. One of these-dried very gradually in the hope of its remaining intact-exploded nine months after it was gathered, and so violently as to break the wooden box in which it was kept quite to pieces. The seeds were scattered in all directions, but would of course have been carried very much further had they been unconfined.

The fruit of the squirting cucumber has to be bound round with copper-wire when ripe, to prevent its shooting out its seeds.

The pods of the Chinese wistaria also explode with a sharp, loud report, and the seeds may be carried at least thirty feet; while those of the American wych- 
hazel are shot out to a distance of from twenty to five-and-forty feet.

If, when these and other similar seeds are discharged, a strong wind should happen to be blowing, they may of course be carried much further; and even if it be not to any really great distance, yet it will give them an advantage; their descendants will advance further still, and thus, in the course of generations, the plants may spread over very wide areas.

Even individual seeds transported by the wind do not always accomplish the whole of their journey 'all in a breath'; for the wind comes in successive waves, not in one continuous blast.

Of a hundred seeds carried off by the wind, all will be dropped when the first lull comes, and when the next gust -or wave rises, probably not more than half will be lifted up again to continue their journey; at the third wave, perhaps ten will be caught up again, but at the fourth or fifth, probably not a single one, for they will have been dropped upon damp earth, or water, into cracks, under bushes, or upon moss, all of which act as traps, and, once caught, do not readily give them up again, even to the most violent blast.

Of course, the lighter the seeds, the better chance they have of being carried far, unless they are caught in these ways; and some few seeds, such as those of the orchids, are so exceedingly minute and light, that no mere lull in the wind is enough to make them drop, for they manage to float even in the still, draughtless air of a hot-house. In this respect they resemble the spores of ferns, mosses and fungi, which can hardly come to the ground at all except when the air is 
almost absolutely motionless, so extremely light are they, being, in fact, rather like pollen than seeds.

Spores, owing to this extreme lightness, travel immense distances over sea and land, and are to be found in almost all dust, whether of town or country ; but in damp weather they are not carried so far, and some of the mosses keep the capsules in which their spores are contained tightly closed, except when the air is dry enough to ensure them a long journey.

Seeds, even the smallest, with very few exceptions, fall straight to the ground when the air is still. Even the tiny seeds of the poppy, campanula, and others do this; but then, on the other hand, small as their weight is, they require something of a shake to dislodge them at all, and as they get this only when there is a tolerably strong puff of wind, they must needs be carried some little distance.

It might seem that large, heavy seeds would be at a disadvantage in respect of wind transport; but as they need a stronger shake to detach them, they do not begin their journey till the wind is blowing with some little force; and then again, being generally borne by trees, and tall trees too, they start at a favourable height, and are often carried a long way.

Seeds have, indeed, been raised as much as 5,400 feet in the air by the wind; but hurricanes are usually local, and do not convey what they snatch up more than a few miles at the utmost.

But we have been looking upon seeds hitherto as if they were themselves perfectly helpless and inactive, which is very far indeed from being the fact. Many of them have special means of their own for ensuring or helping their conveyance from place to place - 
means which vary according to the carriers upon which they depend for locomotion.

Those which are carried by the wind, for example, have elastic spines, wings, feathery tails, down, hairs, all of which help to speed them on their way, and make it more easy for them to be raised in the air, or blown along the ground.

Generally as the lower part of the pistil ripens, the upper part withers, having done its work of conveying pollen to the ovules. But sometimes the pistil-stalk remains attached to the ovary, and is turned to a fresh use. In the wild clematis, for instance, so far from withering it grows, and not only lengthens out but becomes silky and feathery, ready to catch any puff of wind, and very easily carried through the air. When it drops, the heavier end, the ovary with its seed, naturally touches the ground first, and is caught at last, perhaps after two or three journeys, in damp soil or moss, or some crack in the earth.

In the dandelion, it is the upper part of the calyx which enables the seed to float through the air. A dandelion blossom is composed of many small florets, each having its own calyx and pistil. The lower part of each pistil is entirely enclosed in its own small calyx, and inseparably united with it. The upper part of this calyx is divided into fine feathery hairs, which at first form a crown to the ovary, and look as if they grew from it. But later, as the ovary ripens, this crown is pushed upwards on a fine stalk, and looks like a miniature parachute, or an umbrella turned inside out, and it catches the wind as easily, the merest breath being enough to float it.

We need not do more than mention the down of the 
thistle and many other plants, the wing-like appendages of the seeds of the ash, maple, and sycamore, commonly called ' keys,' and the long, paper-like leaf-scales attached to the flower-stalks of the lime, which answer a similar purpose; or the wing-like expansions by which many seeds are themselves bordered, and which act the part of miniature sails.

The seeds of the water-pink of Ceylon are helped on their way by other means; they are enclosed in circular heads, measuring eight or nine inches across, and beset with elastic spines which stand out in all directions. These heads are detached from the stalks when ripe, and are whirled over the sands for miles, bounding along on the spines, and dropping their seeds by the way. Often, of course, they are whirled into the water, and there they float, the upper spines catching the wind, and acting as sails.

Water, indeed, plays a most important part in the dispersal of seeds, many of -which, if carried only a short distance by the wind to begin with, may continue their journey and travel much further if dropped. into river or sea, especially if they happen to reach one of the many ocean-currents.

There are not many seed-bearing plants which grow actually in the water; but one of these, the arrowhead, has seeds which keep afloat a long time, not because they are so remarkably light, but because they are so highly polished as to look and behave as if they had been oiled. They do not even become wet, for water runs off them; and it is not until this polish has been destroyed by much rubbing and long soaking that they can be got to sink.

The seeds of the water-lilies, white and yellow, are 


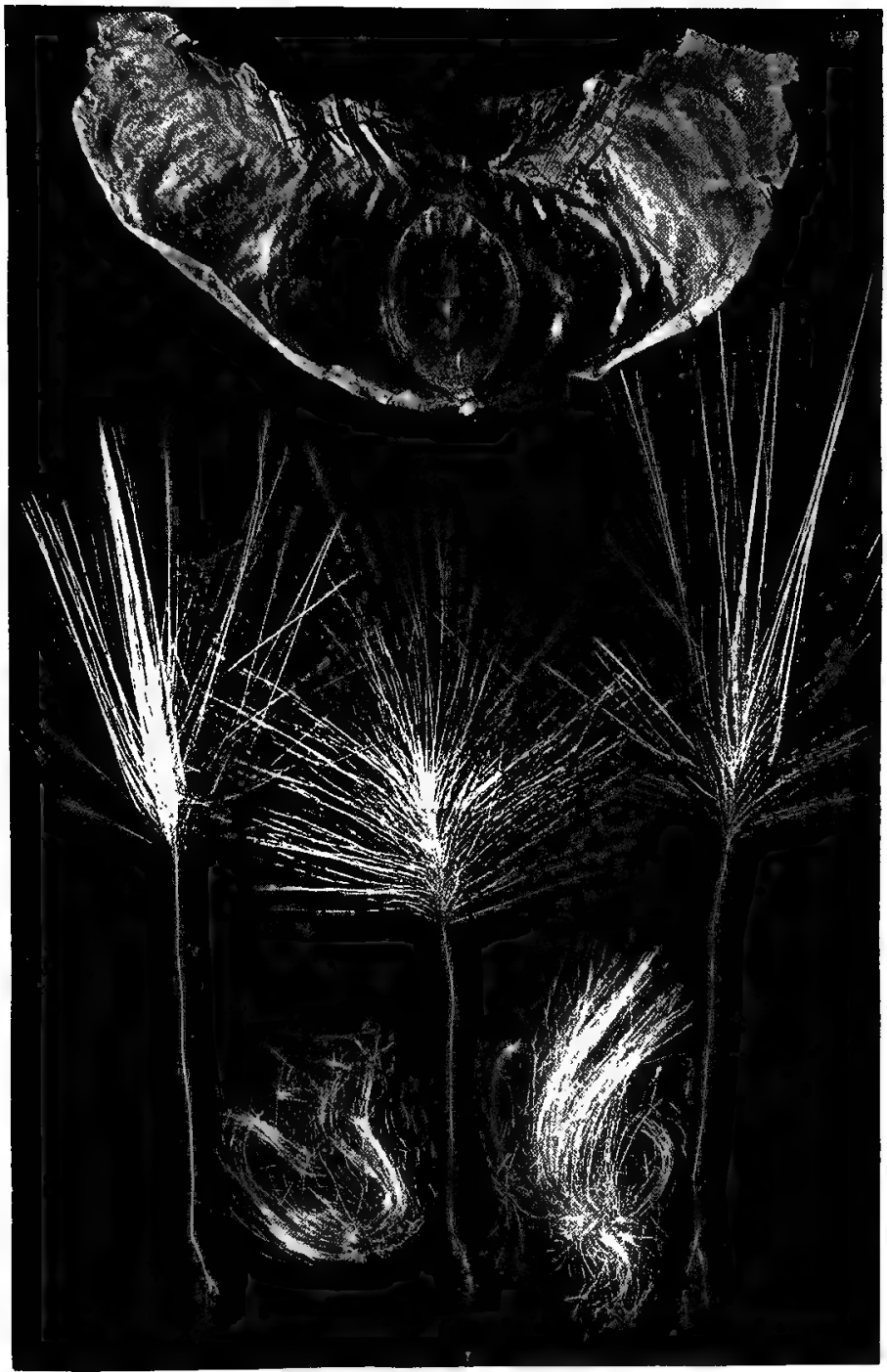



kept afloat for some time by means of air-bubbles. Large fruits often float longer than small ones, and could hardly be transported by any other means than water.

Then, however, comes the all-important question, how far the seeds are affected by remaining for some time in water ; and here again they vary considerably, some being far more hardy than others.

The coco-nut, for instance, being enclosed in a mass of fibre, floats well, and is able to stand immersion in either fresh or salt water for an unusually long time, without losing the power of germinating; and cocopalms, self-planted, are the first trees to spring up upon any newly exposed coral-reef, the nuts having been floated thither from some more or less distant coast. When making experiments to ascertain how long seeds might remain in salt-water without being killed, Mr. Darwin was delighted to find that some grew after twenty-one days'. immersion. Many oceancurrents, as he reckoned, travel at the rate of a mile an hour, so that these seeds might be floated five hundred miles without being any the worse. But, alas! he had overlooked one thing. The seeds had been under water all this time; and as Dr. Hooker reminded him, "If they sink, they won't float!" Seeds vary much as to the length of time they are able to remain afloat, and these seeds could not have been transported at all by water, except under different circumstances, such as while they were still enclosed in their seed-vessels, or even attached to the plant or branch on which they grew.

Some few seeds grew after being kept for 137 days in sea-water ; so that, if able to float, they might have 
germinated after a voyage of more than 3,000 milesa distance greater than that which lies between Europe and America.

The question was, then, whether there were any way in which they might float; and it was found that though ripe, freshly gathered hazel-nuts sank directly they were put in water, they would float for as much as ninety days, and then germinate, if they were first dried.

Now, in the natural state, seeds may often be dried by exposure to sun and air before they are washed, or blown, into the water; and they would, some of them at all events, be then perfectly well able to float. A plant of asparagus, for example, floated nearly as long as the nuts, after being dried, and its berries germinated; and asparagus, being a plant which grows wild on the sea-coast, would have especially good opportunities, therefore, of migrating.

Drying does not answer the purpose with all plants, however; but out of ninety-four, upon which the experiment was tried, eighteen floated more than twentyeight days, and some much longer, quite long enough, in fact, to allow of their being carried from one continent to another.

For Mr. Darwin's estimate of a mile an hour as the rate at which ocean-currents travel, was a purposely low one; several of the Atlantic currents travel thirtythree miles a day, and some as much as sixty miles a day, so that any of these eighteen plants might have been carried some hundreds of miles, and others from three to five thousand, without their seeds being any the worse for the voyage.

Some seeds appear to have no means at all of getting 
themselves transported from place to place; but it will generally be found that these are seeds which have been altered by. cultivation. The grain of wheat and rye, for instance, falls quite naked from the ear as soon as it is ripe, and sinks at once in water; and this is one reason why neither is ever found wild. Rice is a little better off, for each grain is enclosed in a rough, hard case, which effectually preserves it from injury, and probably in its natural state it was able to float on water. But now that its size and weight have been increased by cultivation, it sinks like the others.

Many bean-like and pea-like seeds stand immersion extremely well, and some of these, conveyed 3,000 miles or so by the Gulf Stream and cast upon the Azores and on the Orkney islands, have been successfully grown at Kew Gardens, though they could not establish themselves in either group of islands owing to the unsuitable climate of both.

Among the islands which have been especially indebted to ocean-currents for their vegetation, may be mentioned the Bermudas, more than half of whose flowering plants are supposed to be colonists. The greater number of these belong to the tropics and West Indies, and have been to a large extent brought by the Gulf Stream, which is constantly throwing up various objects on the shore-the seeds of trees among the rest. The soapberry-tree, for instance, has been observed to spring up in this way, from seeds thus cast ashore.

Seeds may occasionally chance to be conveyed across the ocean in drift-wood, without ever coming in contact with the water at all; fo: stones and small 
quantities of earth are sometimes found perfectly enclosed; and from the earth thus entangled in the roots of an oak, Mr. Darwin was able to grow three plants.

But again, there is another way in which seeds may escape contact with water: dead birds, having seeds in their crops, may now and then escape being devoured, and may be floated long distances by river or oceancurrents; and, as many seeds retain their vitality after being in a bird's crop for thirty days, some may be conveyed in this way from time to time.

The so-called 'goose-wheat' of Canada was first sown from grain found in the crop of a wild goose which was shot on its way, probably from Alaska, or the Russian settlements on the other side of Behring's Straits. Migratory geese invariably take to the stubbles when on their way to the south in autumn, and many or most of them would probably be found to have grain in their crops, though the chances of its getting planted are small. In this case, however, the 'wild-goose barley,' as it is also called, has become a permanent colonist, and is still grown in Saskatchewan. 


\section{XVIII.}

\section{SEED-CARRIERS}

The seed-carriers now to be considered are employed for the most part with as little reference to their own wills, and often with as little knowledge on their parts, as the winds and waves. The seeds simply make use of them as carriers, whether they will or no, and that no matter whether they be birds, animals, or even men; for all are pressed into the service, and know, for the most part, nothing of what they are doing. We are, of course, not here speaking of man's voluntary importations, but of his involuntary ones, which are probably almost as many.

There are, however, some few voluntary carriers among both birds and animals-carriers who, though in one sense quite unaware of what they are doing, yet for purposes of their own do carry seeds from one place to another, not very far probably, but often the distance of a few miles.

Some birds, for instance, take a positive pleasure, as it would seem, in carrying things about for the mere sake of carrying them; and the propensity is especially strong in the crow tribe, including not only crows, but rooks, jays, magpies and jackdaws, many of which also have a great love of hiding as well as carrying. 
Rooks seem to be especially busy in this way, at all events in America, where they are said to be perpetually carrying things about in their claws, with which they are able to grasp even hens' eggs.

On one occasion a large number of fowls, destined for New Orleans, had been collected at some spot up the river, and as the boat which was to convey them was not ready, they were turned out into the woods for about a week to shift for themselves. During this time they laid about two thousand eggs daily, a fact which seemed immensely to interest the rooks of the neighbourhood. For, whether with a view to eating them, or simply from a love of being busy, they devoted themselves to carrying the eggs away, and burying them in a field more than half a mile off on the other side of a creek. A month or two later, when the field was ploughed, the eggs were turned up in hundreds, and being still perfectly good, supplied the labourers with many a meal.

But now, supposing that the rooks had buried acorns instead of eggs, and that the field had been waste ground, where plough and harrow never came, might not a small forest of oaks have sprung up? and may not many a plantation of oaks, beeches, sycamores and other trees, have been planted in a similar way?

A certain pine-forest in Minnesota, for example, on being cut down, was at once succeeded by oaks; and a similar thing is said to have occurred in North Carolina, with nothing in either case to account for it. The oaks seemed to have grown of themselves; but since oaks must certainly spring from acorns, it seems at least possible, and indeed probable, that rooks may have been the planters. 
Rooks are always busy in the wild state, and, as the American writer before quoted remarks, on leaving an oak-tree, the bird will often pluck an acorn, which it may carry perhaps five miles; then, if it alights upon a beech, it will drop the acorn and gather nuts instead, and so on, taking a fresh remembrance away wherever it goes, and sowing seeds innumerable in the course of its life.

But when the rooks assemble in their hundreds to hold a "pow-wow' or parliament, then is the time when they do their sowing on a large scale; for, true to their usual habits, many, if not all, bring and drop something. The place chosen for the assembly is always open, and more or less bare, and afterwards the ground may be seen strewn with walnuts, hickory nuts, acorns, sticks and other rubbish. This, at least, is how rooks behave in America; and a field is mentioned which, after being left to itself for some time, was found to be full of young 'bur-oaks,' there being no parent-tree anywhere near from which the acorns could possibly have been carried, even by a high wind.

Now, how could these have been planted, save by birds? Pigs simply crunch up and eat nuts and acorns where they find them; and though the squirrel sometimes carries them several hundred yards, it seldom does more, while the field-mouse certainly does not lay up her winter-store very far from where her crops grow. Besides, neither tree-squirrels nor mice act in concert, and planting on so large a scale must have required a small army to accomplish it.

No doubt, however, both tree- and ground-squirrels, as well as mice, are responsible for the planting of 
many a single nut-bearing tree; for sometimes they may be startled, and made to drop their treasure before they reach home; some may forget their storehouse, and some may die before it is empty. Still, the result of any of these accidents will be rather solitary trees than groves, or even groups; for in the case of an abandoned store-house, though many might sprout, only one or two would have a chance of growing.

But the gray tree-squirrels may have done more, for, unlike the red, and the ground-squirrels, they bury their winter-store of nuts and acorns separately, one by one, about a couple of inches deep; and though they have such good memories as to be able to find them again, even when buried under a foot of snow, no doubt in many cases accidents have happened, and their stores have been left undisturbed, and would have excellent opportunities of growing. The number of these little animals in North America was something extraordinary in bygone times; for in one year (I749) 640,000 were destroyed in Pennsylvania alone. They may well, therefore, have done a great deal of planting, though they would probably not carry their nuts far.

The nuthatch often plants quite a colony of young beeches around its haunts; for it has favourite trees to which it resorts, after twisting a cluster of nuts from the bough; its object being to fix the nuts in some crevice of the bark where it may hammer at them. Very often, however, it fails in the attempt, the nuts fall to the ground, and, under favourable circumstances, germinate.

Monkeys, also, sometimes carry nuts and fruits to a 
distance before eating them; and if meantime their attention be caught by something else, they will probably drop and forget all about them. Brazil-nuts, for instance, are enclosed in such a very hard, strong outer case that no monkey can get at the contents, except by hammering it for a long time against a rock, or a hard log of wood, neither of which is always to be found close at hand.

So much, then, for the voluntary carriers, whose work is but small and limited, compared with that of the great army of involuntary carriers.

Look, for example, at a dog when he has been hunting in a ditch, and see how the burdocks and goose-grass, or cleavers, have taken advantage of him, and made him act as carrier for them. Their fruits are thickly set with tiny hooks, and with these they have laid hold of his coat, entangling themselves in it, and holding so tight, that though he may roll and bite, and try in every way to rid himself of them, he will often carry some about with him for days; and if on some long expedition, might travel a good many miles before he had freed himself from them all.

Now, what is true of the dog in this respect is true also of many animals, wild and domestic, including man himself. The fleece of sheep, the fur and hair of other animals, the feathers of birds, the clothes of human beings-all answer the purpose of these hooked, barbed and thorny fruits, by giving them something which they can lay hold of. No doubt we have all noticed the extraordinary way in which the seeds of the wild barley work their way into one's garments, and remain for months unless picked out. The seeds of the porcu- 
pine-grass, too, cause positive annoyance by a similar habit of sticking into socks and trousers.

This is the way in which seeds of these sorts get themselves transported; and accordingly it will be found that fruits furnished with these means of laying hold of the passer-by generally grow low enough down to be within reach of some one or other of these means of conveyance. Hides, fleeces, hair, wool, fur, feathers, manes, tails-all are turned to account, and made useful.

It is true that both birds and quadrupeds are frequently cleaning themselves, and do not willingly carry anything of the sort about with them; but when once a bur has attached itself, it is very difficult to get rid of again; and the animal which it has made use of will generally be obliged to carry it for a time, however unwillingly.

We have abundant proof of this in the way in which more than one plant has been introduced, not only from one continent, but from one hemisphere, to another, within recent times.

The 'Bathurst bur,' among others, is a striking example of the successful emigrant. Growing in Patagonia, it got itself conveyed to Australia, where it has flourished ever since in the most rampant manner. The first step was to hook its burs into the tails and manes of horses, which it did most effectually; and then, as chance would have it, some of these same horses were imported into Australia, burs and all, for so thoroughly were they entangled that the animals had not been able to shake or rub them all off, even during the voyage. Some no doubt were got rid of, but enough remained to make a fresh start in the new 


\section{Seed.Carriers}

country; and they did it with such energy, that within a few years it was found necessary to pass an Act of Parliament 'against the growth of thistles,' and all persons allowing them to remain on their land, or even on their half of the road, were made liable to heavy fines.

The 'Bathurst bur' was in fact, from man's point of view, a terrible nuisance; but from its own, it was a peculiarly successful colonist. It had secured such a change of air and change of soil as agreed with it amazingly; it had made use first of the horses, then of man, to attain its object; and finally, on reaching the new continent, its downy seeds, being fully ripe, had been launched on the winds, and borne hither and thither to their new settlements. Their descendants, again, had been carried yet further afield, and so with giant strides it had advanced over the country-a most successful plant!

The merino sheep has been similarly instrumental in introducing another thistle-like plant to South Africa. Indeed, plants with downy seeds have been eminently successful, not only in dispersing their offspring far and wide, but also in becoming naturalized-making themselves so thoroughly at home in their new quarters that they are able to mature their seed, and so to propagate their species without artificial help.

But birds are the great carriers; and the migrants, especially, transport such seeds as lay hold of them to much greater distances than quadrupeds ever travel, at least without the help of man.

There is a species of sedge which grows by the water in the highlands of Jamaica, whose fruit is 
provided with long bristles, something like a shepherd's crook, the hooked part being so closely fitting and elastic as to grasp the finest hairs, if drawn across the back of the hand. It grasps them so tight, moreover, as to pull them out, sooner than let go. The highlands where this sedge abounds are the spots generally first touched by migratory birds, and in some cases small birds are caught and held so firmly by the sedge's hooks as to be quite unable to escape. Larger and stronger birds of course get away, but must carry many of the seeds with them; and these, as the bristles wither and relax their hold, are dropped by the way. Accordingly the sedge is plentiful all along the track followed by these birds - the east coast of North America, that is, and the adjacent islands, among which the Bermudas are visited by large numbers of these migrants.

Birds, such as the puffins, which burrow in the earth, get their feathers covered with vegetable mould, which is sure to contain spores and seeds, some of which may cling long enough to be carried at least part of the way, when the birds leave their inland nesting places for the coast, where they spend the greater part of the year.

Birds, it is true, are generally very particular in keeping both beak and feet clean, but still sometimes they are found with little cakes of earth adhering to them; and seeds are so very common in all soil, that some no doubt are transported in this way. Indeed, eighty-two plants have been grown from the earth taken from the leg of a single partridge, and that after the earth had been kept three years. This partridge had carried as much as six and a half ounces of earth on 
its leg; and what one has done, others of course may do, and probably have done. Still, dirt on feet and beaks is rare.

The birds most likely to have muddy feet are naturally the waders, and those which frequent the edges of ponds and moist and muddy places. And these, if they carry away mud, are certain to carry away seeds also, for damp soil catches and keeps the seed dropped upon it in a way that dry soil cannot. From about a breakfast-cupful of mud taken from under the water, and from the edge, of a small pond, Mr. Darwin succeeded in raising 537 plants.

Now the birds which frequent bogs and marshes and other muddy places, are also the very birds which wander most, the migrants, in fact, chief among which, for the wide extent of its journeyings, is the woodcock; for there is hardly any island, however remote, but the woodcock finds its way thither, and no doubt it has carried in its time many a seed, which has been dropped again in soil as muddy as that from which it was taken, and has therefore had a good chance of establishing itself

But, though birds convey seeds both in their feathers and in the mud on their feet, they no doubt convey many more in their crops. There is no gastric juice or anything else in the crop to injure the seeds in any way; and when a large supply of food has been taken, the grains do not all pass into the gizzard for twelve, or even eighteen hours, in the course of which time a good deal might happen. Birds, for example, are occasionally blown the whole way across the Atlantic, the wind carrying them on at the rate of thirty-five miles an hour; and they might well, therefore, be 
carried 500 miles before all the grain had passed out of their crop, if they had just had a full meal.

Supposing them to be blown overland, instead of over sea, or to reach land after a few hours, they might then be pounced on by the hawks, who are always on the look-out for weary travellers. These, like the owls, bolt their prey whole, and after some hours disgorge pellets of feathers and other undesirable matter, among which might be the seed in the crop of their victim, still uninjured. This, indeed, is no mere speculation, for it has been found by experiment that such pellets do contain seeds, such as oats, wheat, hemp, millet, clover, and canary-seeds; all of which may be capable of germination. Or again, a bird with seed in its crop may be struck down by'a hawk after flying some considerable distance, and the hawk in its turn may be driven away from its prey before it has done more than tear the crop open. In this instance, too, the seed may fall where it will be able to germinate, and the plant may be able to establish itself; and though such cases are exceptional, one single successful seed is enough to introduce a plant to an entirely new neighbourhood, where, under favourable circumstances, it may spread and become completely naturalized.

Seeds vary very much as to their power of resisting digestion. Many are, for the most part, quite digested, but there are others which are protected against digestion by a covering so hard, or so tough, that it is a real help to them to be swallowed, as they germinate more readily when this covering has undergone some amount of softening.

Seeds, for instance, which are swallowed, not for their own sake, but for the sweet flesh surrounding 
them, are more or less hard, and some stone-like. Even the seeds of elms, firs and ashes, often escape not merely uninjured, but actually helped by being swallowed; and the same is true, in a much more marked degree, of the stones of the cherry, sloe, raspberry, blackberry, and the seeds of the apple, and the tiny nuts of the strawberry.

In some cases birds render a positive service to man, also, by swallowing and scattering the seeds of plants which he cultivates. The cinnamon-tree, for instance, has been introduced in this way into the interior of Ceylon from the gardens on the coast; and as the wild trees are just as good as the cultivated ones for commercial purposes, their shoots are regularly cut for the trade.

So, too, with the pimento, allspice, or Jamaica pepper-tree. All the present 'pimento walks' of Jamaica, as the plantations are called, have been sown by birds; for though the plants can be raised in nurseries in large numbers by careful treatment, the planters are of opinion that the seeds are better prepared by the birds. And why should they incur the trouble and expense of this 'careful treatment,' when the birds do all that is necessary?

When a new 'walk' is wanted, all that is necessary is to enclose a piece of waste ground near an old 'walk.' The birds eagerly eat the fruit when ripe, and the seeds are dropped, with the result that twelve months after the first rains abundance of young plants are to be seen growing vigorously in all parts of the new enclosure. If not enclosed, the plants would be eaten off or trodden down by wild animals; but this amount of protection is all that they require. 
Turkeys are employed to prepare the haws when hawthorn hedges are wanted, in some parts of France; for the bony cores are quite indigestible, and are softened by being swallowed. Blackbirds, jays, and others keep the haws in their crops for a time, and then bring up the seeds clean and whole, with the thin covering of flesh gone; and no doubt they are responsible for the planting of many a thorn-tree.

Some trees seem to be entirely dependent upon birds for getting their seeds scattered, and cannot spread without them. The red cedar is apparently one of these; for, though introduced into Indiana nearly fifty years ago, it did not run wild, and was not to be found in the forest, until some of the birds became sufficiently familiar with it to venture to eat the seeds. During the last few years numbers of young saplings have made their appearance, and it is likely to be one of the forest-trees of the future. The seeds of the red cedar have so hard an outer covering that gardeners find it well to scald them before planting; and it is therefore, no doubt, a great advantage to them to be swallowed.

How, except by being swallowed by birds, does the mountain-ash berry get conveyed to the top of high walls, where young trees may sometimes be seen growing? How, save in this way, does the mistletoe reach the top of the oak? or how do the wild-rose and privet find their way to the walls of Cologne Cathedral? The reader may possibly be inclined to add another ' how' to the series, and ask how, when they get there, do they manage to find soil to germinate and grow in? But, as already remarked, a very little soil is enough for seeds to sprout in; and this, in the case of build- 
ings, is provided first, probably, by the decay of lichens and mosses and of the stone itself, and also by the wind, which conveys many a little pile of dust into sheltered nooks and corners. As for the mistletoe, being a parasite and living by the labour of others, it has no difficulty about soil, and makes itself at home not only on the oak, but on other trees, above all on the apple.

In the forests on the Amazons, plants without number may be seen growing on the trees, some of which, as the ferns and orchids, have no doubt been sown by the wind; while there are others, such as the fragrant pink-and-white clusia, which are equally surely sown by the birds. The large, round, whitish fruit of the clusia, called the 'wild onion,' is much eaten by' birds, and is to be seen growing on almost every other tree.

Tropical birds, whether in the east or in the west, are all chiefly fruit or insect eaters; while in temperate latitudes, where there is much grass, seed-eaters abound, and a mixed diet is more general.

The fruit-eating, and consequently seed-carrying, birds of the tropics are the countless multitudes of the parrot tribe, which usually feed in flocks of thousands, and wander far in search of food; and, besides these, there are many fruit-eating pigeons, hornbills, and others. Nor must the inımense flocks of large fruitbats, or flying foxes, be overlooked; for their numbers are so enormous that they often take hours to pass, while their depredations in the orchards are carried to such an extent as to make them one of the greatest pests of the tropical fruit-grower of the East. In his absence, however, the fruit-eaters have done, and 
do, much valuable service in the way of carrying seeds.

Seed cannot be sown to any purpose until it is ripe, and it would therefore be simply wasted if the birds carried it off too soon. But it is safe enough from them while it is unripe, for the eatable part, the flesh surrounding the seed, is unripe too, as the birds very well know, and they leave it severely alone. Green fruit they do not like, probably because it is indigestible; for one would not suppose the flavour to be of much consequence.

The fruits of the bird-cherry, hawthorn, ash, sloe, and many others are of a size to be swallowed whole; and as, to our taste at all events, they have no flavour to recommend them even when ripe, a little unripeness would not seem to matter much, except as regards the seed. But for this it would matter greatly, and the birds are therefore warned off until it is ready to benefit by their attention. When the right time has come, the fruit changes colour and becomes more conspicuous-a notice which is perfectly understood.

Red, yellow, purple, and black are the most usual colours of ripe fruit, and these the birds seem, therefore, to understand best ; for they seldom touch white currants till the red are gone, though the white are the sweeter of the two; and they have been observed to leave unnoticed a holly-tree bearing yellow berries, while they stripped other trees near of their ordinary red ones. Yellow holly-berries being uncommon, these were probably considered to be still unfit for eating.

Though birds swallow their own small fruits whole, they seem to appreciate the sweeter flavour of those which man has improved by cultivation. But as seed- 
carriers they are distinctly out of place both in orchard and kitchen-garden; they are not wanted in that capacity, and, in fact, if they were, they are incompetent; for, where cherries and plums have been so increased in size that they can only be pecked at, not swallowed, the flesh only is taken, and the stones are left.

Where plants are cultivated for the sake of their leaves or roots, not their fruit, the former are altered, but the latter remains the same, with the same means of getting its seed carried to a distance which were possessed by the plant's wild ancestors. The fruit of the garden carrot, for instance, like that of the wild, is covered with minute hooked bristles; that of the parsnip is winged; and the seeds of the onion, tobacco, and flax are just as easily scattered by the wind in the cultivated as in the wild state.

But to mention, in conclusion, some of the other seed-carriers besides the birds. Among these must be reckoned fish, locusts, cattle, and, perhaps above ail, pigs.

Fish swallow the seeds of many water and land plants, including even the large seeds of the water-lily; but, being confined to their own pond, lake, or river, their range is necessarily limited. When, however, they, in their turn, are swallowed by herons, storks, kingfishers, and other fish-eating birds, the seeds may be conveyed to much greater distances and be dropped quite uninjured. Some large seeds of the great southern water-lily, for instance, found in the stomach of a heron, had probably first been swallowed by a fish.

The locusts which frequent parts of South Africa are believed by the farmers to have introduced there various new plants which are injurious to the grass; 
and it is a fact that undigested seeds, capable of germinating, are found in their droppings.

Cattle and pigs, but especially the latter, are responsible for the rampant way in which apple-trees are now running wild and forming extensive groves in the Pampas. The pips are so well protected as to be indigestible even by a pig; and the same may be said of peach-stones, which have also been extensively scattered in New Zealand and elsewhere, by similar means and with similar results. 


\section{XIX.}

\section{CHANCES OF LIFE}

OF all the wonderful things in nature, surely a seed is one of the most wonderful. How dead and helpless it looks; how very little it tells us about itself, and yet how very much is wrapped up in it! Seeds, especially small seeds from the same plant, look just as much alike as grains of sand. Indeed, peas have become proverbial; and we say 'as much alike as peas in a pod,' when we mean that things, or people, are quite without individual character.

And yet each seed, even the smallest and most dustlike, has a character of its own-a character which distinguishes it not merely from other seeds of different families, but a character which distinguishes it also from all its nearest relations, even from those which grew in the same pod with it.

Probably it is only want of sight which prevents our seeing the difference between one seed and another, for certainly even the most careless observer will admit that he has never yet found two perfectly identical plants. Not even two peas, taken from the same pod, will grow up precisely alike.

But as long as the seed is kept from its natural bed 
in the earth, it not only looks dead, but is dead to all intents and purposes, for it has no means of showing that it lives-dead, however, with a possibility of life, which generally grows less and less. the longer it is left unburied. When the life has died out of it wholly, it still looks much the same as before, at least to the unpractised eye.

As to living seed, if it be one that we know, we can tell at a glance what sort of plant bore it, and what plant will spring from it. But if it a seed that we do not know?

Well, even then, we may be able to tell by the look of it what family it belongs to, whether it is starchy or oily, whether it will have two seed-leaves, like a bean, or one, like corn. But our knowledge will not carry us much further. In many cases it will not even tell us whether the forthcoming plant will be a tree, or a shrub, or a lowly herb. To the inexperienced, many of the smaller seeds especially look very much alike; and there is certainly no such difference in their appearance as would lead one to guess at the great variety of plants which will spring from them; and even the wisest knows very little about the why and the wherefore of the matter.

For why should the small seed of the elm produce a tall tree, ind the large seed of the gourd only a shortlived, weak-stemmed, creeping plant? Why should one bean grow to the height of a few inches only and another climb up several feet? Why, again, should an acorn always produce an oak and not some other tree? All that we can answer is, an acorn has oaklife in it. But we might as well say we don't know, for all the light this throws upon the subject. 
Look now at these seed-pods and seeds. We may know that they have been taken from plants of the great cabbage family; but the family likeness is so strong between them that we should probably be puzzled to say which would produce red cabbages and which green, and from which will come crinkleleaved savoys, curly-leaved kale, Brussels sprouts, broccoli, or cauliflowers. All these are but varieties of the cabbage, though they are so very different in appearance; and as long as they are only seeds, they are so nearly alike that their secret is quite safe from ordinary people.

Even when we know that certain plants will spring from certain seeds, we are in many cases quite unable to tell what the colour of the blossom will be. There is no difference at all to be detected in the seed, yet one seed will produce blossom of one colour and another of another. But why?

For instance, from the seed of the verbena, phlox, and sweet-pea, we know, because it has been so in the past, that we shall get verbenas, phloxes, and sweetpeas; and we may go a step beyond this, and say that there will be no quite blue flowers, nor any yellow ones among them. This we know from experience. We know, too, that, though the seeds of each sort look so exactly alike, no two plants will be absolutely similar, and the blossoms will vary much. Some of the pea-blossoms may be pink of different shades, others pink and white, or purple, though they grow side by side; and there will be still greater variety in the colours of the phloxes and verbenas, some of which will also have white eyes and some not. But 
we cannot tell by looking at it which seed will produce which blossom.

And even if, in some cases, we should be able to do this, we are still not a whit nearer solving the mystery of the how and the why. We may conclude that there is some minute difference in the food which the roots take up, according as the blossoms are of one colour or another; for we know that the pink hydrangea will turn blue if supplied with an extra amount of iron; and we may argue that, though the peas all look alike, one has that within it which causes it to take up what will produce pink blossoms, and another that which will produce purple ones. But it is a mystery still.

We may prevent their growing at all, we may keep them till the possibility of life has died out of them; or, though we let them grow, we may prevent their blossoming; but if allowed to grow and blossom without interference, in their native soil, one will bear its pink, and another its purple blossoms without fail.

But if the seed tells us nothing as to the colour of the blossom which will spring from it, it often tells us also just as little as to the size of the plant which it will produce, and the length of that plant's life.

Here, for instance, are three seeds of different sizes, but all belonging to the bean-like or leguminous order of plants. Supposing that we had never seen them before, and were told that one would produce a tree, another a shrub, and the third a dwarf annual, should we be likely to guess that, from the two smaller seeds, would grow a laburnum and a broom-plant, while from the third, which is so many times larger, would spring only a broad, or Windsor, bean?

Some of the orchids bear large blossoms, and others 
large masses of blossom; yet their seed is almost dustlike. The seed of the lobelia and of the scented tobacco is about equally minute; but from the one springs a plant only a few inches high, with quite small blossoms; and from the other, one which grows to a height of two or three feet, and has blossoms at least four inches long.

Then, again, size of seed has nothing at all to do with length of life. The large broad bean has life only for a single season; the small laburnum-seed has life which lasts for years. The lupin, another leguminous plant, is both an annual and a perennial; but, strange to say, the perennial lupin bears the smaller seed, though it not only lives longer but is also the taller plant, and produces more blossom of the two.

An oak may live as many centuries as a béan does months, or more; but who can say why?

The famous chestnut-tree on Mount Etna is said to be 1,000 years old; and among other ancient trees, whose age is more or less well attested, there is an oak reputed to be 1,600 years old and a walnut of 900 ; there are olives which are believed to be 2,000 years old; and there is at least one tree in the East which tradition affirms to be even 6,000 years old! But, again, why an olive should outlive an oak, who can say?

There is a great difference, also, as to the length of time during which the seeds themselves retain their vitality or power of germinating. Most of them look equally lifeless; but in some this mysterious power lasts much longer than in others, and this, too, with very little reference to their size, though large seeds, especially oily seeds, have some advantage. The seed 
of the coffee-berry, for instance, is worthless unless planted without delay directly it is ripe; and willowseed is said to live only a fortnight after ripening, or less, if it is allowed to become dry. Seeds of melon and geranium, on the other hand, have been known to germinate after being kept, merely wrapped in paper, for thirty years. It is believed that, if melon-seeds produce plants at all, after being kept for some time, their crop of fruit will be all the larger; but they are commonly supposed not to live longer than seven years, and even within this period the longer they are kept the smaller is their chance of germinating considered to be.

Cases, however, have been known in which certain seeds. quite small seeds, too, have kept the life in them not only for years but for centuries, and evers millenniums. We are not alluding to the famous mummy wheat; for the grain of wheat, being quite unprotected except by a thin husk, loses all power of germinating in a few years at most; and none of the interesting stories told of wheat raised from grain found in Egyptian tombs have ever yet been satisfactorily proved.

Grain taken from mummies has germinated sure enough, but it has been grain recently introduced by the Arabs! In one instance the plant raised bore oats; but this was unlucky, for oats were not known to ancient Egypt; and in no single case has any success attended the innumerable attempts made to raise plants from genuine mummy wheat. But seeds found in Roman tombs have not only germinated, but produced plants.

Of all wel!-authenticated cases, however, the most 


\section{Chances of Life}

remarkable is that of the seedlings raised by $D r$. Lindley, in Chiswick Gardens, from raspberry-seeds found in Celtic tumuli perhaps some two thousand years old. Raspberry-seeds have very hard coats, it is true, and these seeds were safely buried from the air, and beyond the reach of any great changes of temperature; but yet that things so small should have been able to preserve living germs within them for so long a time is a wonderful proof of their great tenacity of life.

Generally speaking, it seems that the seeds of wild plants have the advantage over the cultivated in this respect. They retain their vitality longer; but then, on the other hand, there are not so many of them. Cultivated plants usually produce most seed-except, of course, where blossoms have been doubled or fruit improved at its expense.

When one considers the vast quantity of seed produced, and the ample contrivances for scattering it, it is surprising to find that, after all, many plants do not increase their numbers at all. There are just about the same number of them now that there were years agoneither more nor fewer.

Take, for example, the common wild spotted orchis, a single plant of which often bears as many as thirty seed-vessels, each containing 6,200 seeds. Suppose that there were 400 bad seeds to each capsule, I2,00o in all, which is a fair allowance, one plant might still be the parent of 174,000 others-enough to cover nearly an acre of ground if the plants grew just far enough apart to allow a proper amount of space to each. The descendants of these, again, might more than cover the 
Isle of Anglesey, and the great-grandchildren of the one original plant would more than clothe the entire land-surface of the globe!

This calculation was made by Mr. Darwin ; and yet, as he goes on to observe, the plant is actually not increasing at all in most places, although it is a perennial, and although its seeds are so minute as to be easily wafted to a great distance by the wind. So, then, only one seed out of the thousands borne by a single plant can come to anything, and even that not every year, but only once in several years; for, as each plant lives some years, there must be an increase in its numbers if but one new plant grew up every year.

That the seeds are scattered, and widely scattered, is unquestionable, for seedlings have been found eight or ten miles away from where any plants grew; but it is equally certain that there is some effectual check to the plant's increase, though what that check is remains unknown.

It is plain, therefore, that the mere scattering of the seed, however necessary as a first step, is far from being enough to secure that the plant shall be able to establish itself in a fresh locality; and the farther the seed is carried the greater the risk it often runs. Some plants are much better able than others to adapt themselves to altered circumstances, and these, of course, make the better colonists; but even they may be quite unable to effect a settlement simply for lack of space. Others find that soil, or climate, or situation do not suit them, and soon die out for that reason. Others, again, though they may find ample room, and all things else to their liking, are quite unable to become permanent colonists because they cannot fertilize them- 


\section{Chances of Life}

selves, and, if there are not the right insects to do it for them, they cannot produce any seed. Such plants as have more than one 'form ' (see p. 222), and such as bear pollen and ovules on separate individuals, run, of course, especial risks when they migrate, as one is generally helpless without the other.

In the matter of soil, too, a very short distance often makes a great difference. The bee-orchis for example, grows plentifully on the chalk in Surrey, and one year it suddenly made its appearance in a clayey field near Thames Ditton, where it had never been seen before. About a hundred plants blossomed in this one field, and nowhere else in the neighbourhood. But they gradually dwindled away, and in the course of six or eight years all had entirely disappeared. The seeds had probably travelled to the clay-field in some chalk which had been brought from another part of the county, but the colony could not be a lasting one for some reason-most likely owing to the change of soil, and perhaps also of situation.

Then, again, there is the milk-thistle, which has run riot in Australia, but has utterly failed to make a settlement in New Zealand. Single specimens have been grown in the latter country, and have seeded freely. The seeds, too, after the manner of their kind, must have been carried hither and thither by the wind in multitudes; but still the plant has not spread, and is a failure-a fortunate failure-as an emigrant.

Other European plants, to the number of more than a hundred and fifty, have been quite successful in New Zealand, and are thoroughly established ; but, it is remarkable that, while so many European plants have made themselves at home there, only two or three 
Australians have managed to do so. Yet Australia is nearer than Europe, and the intercourse between the two countries is much more close and frequent than it is with Europe. Moreover, Australian seeds have been purposely and extensively scattered in New Zealand, among them being, we may be sure, the seeds of such common kinds as those of the acacia and eucalyptus; yet none of these trees are to be seen growing wild.

It is the same with our own garden-plants. How many there are which, though they grow in the garden without any special care, and bring abundance of seed. to perfection, yet never run wild, even to the extent of appearing on just the other side of the wall or hedge! Yet it is impossible to suppose but that the seed is often carried beyond these limits; and weeds make their way in without difficulty.

In considering what becomes of the vast amount of seed which is annually ripened, we must, of course, bear in mind that a great deal is consumed as foodluckily for us; for if there were no seed-eating birds, we should be overrun with thistles and other weeds. Some seed also falls upon soil which does not suit it; some requires burying, and gets killed by remaining exposed; some cannot germinate without special preparation of itself or the soil, or both; still more, if transported to a distance, will find the climate unsuitable.

But in many cases want of space is the only obstacle, and a very serious one it is. There is generally plenty of room for weeds in a garden, and they are not slow to take advantage of it; for there is a good deal of crowding on the other side of the wall, where, in fact, a constant struggle for existence is going on, and only 
the stronger survive. Seeds falling upon ground already covered, and thickly covered, with vegetation, as a hedge-bank generally is, have but little chance. In fact, they hardly reach the soil at all, the great inajority of them.

Look among the long meadow-grass, and you may often see hundreds and thousands of downy seeds caught among the stems and suspended, each with its seed pointing downwards, ready to take acivantage of any crack in the soil in which to insert itself, but quite unable and unlikely to reach it. And even of the seeds which do reach it, how many must find that the firstcomers are stronger and better fitted for the situation than themselves! and so, even if they spring up, they are speedily overpowered and crowded out.

This, of course, is especially the case with such seeds as are transported long distances and to other quarters of the world, where the chances are that they will find the soil already occupied by natives, among whom they will be choked. Should they find a bare spot, however, and soil and climate suitable, they will still be unable to do more than effect a temporary settlement-will not, in fact, become really naturalized-unless the plants can either fertilize themselves or find insects able to do the work for them. In the matter of space, those, of course, have a great advantage which grow upon others, as fresh surfaces are being constantlv prepared for them.

The number of seeds produced varies enormously in different plants. Orchids produce them at the rate of thousands to each blossom; and some of the foreign species go far beyond this, a single seed-vessel containing more than million and three-quarters of seeds. 
The blossom of an oak, on the other hand, produces but one seed. But the advantage is not all on the side of numbers; for the greater the number, the smaller the size; and the smaller the seed, the smaller the germ, and also the smaller the supply of ready-made food with which it begins life. A large seed, such as a bean, has a large, strong germ; and its two thick seedleaves, which are really store-cupboards, can supply the seedling with plenty of food, so that it starts with much in its favour. And so ten large seeds will often, it is said, yield more plants than some thousands of small ones. One may also conjecture that, when an ovary contains ovules by the thousand, or million, each requiring the contents of two or three grains of pollen at least, and some as many as twenty, it is not unlikely that some will be left out, and, failing to get what they want, will not succeed in becoming true seeds at all.

One perfect seed to each plant in the course of its life is enough to ensure that, at all events, it shall neither die out nor suffer any decrease in its numbers; but while the oak will be able to hold its own if it have but one sound acorn in the course of a few hundred years, the chickweed must have one good seed every year, if it is to keep up its numbers. This, of course, is supposing that the one seed is allowed to produce a seedling, and the seedling to grow up into a plant; but, as much seed and many seedlings are devoured, many more are actually required.

Neither the acorn, nor the chestnut when it has left its shell, has anything to protect it, except its colour, which being like that of the earth, or of dead leaves, may sometimes enable it to escape notice as it lies on the ground; and if but one escapes now 
and then, at long intervals, once in a few centuries, the stock will be kept up, though not increased.

Small seeds have a better chance in some ways, as they are more easily sheltered, and hidden from the bright keen eyes of the birds. A bed of damp moss is a capital hiding-place; and so are the cracks which open in the soil when the earth is dry; for these close up again when the wet comes, and the seeds are safely buried out of harm's way. Cracks may often be seen full of seeds.

Still, 'if you want a thing done, do it yourself,' is an excellent motto even for seeds, and it is an advantage to be independent even of cracks! This is what some seeds are, especially a good many grass-seeds; for instead of waiting to be buried, they set to work and bury themselves.

The seed of the grass Aristida, for instance, is enclosed in a couple of husks tipped with bristles, each divided into three fine tails, six or eight inches long, which stand out in different directions more or less at right angles to the seed. When the seed falls to the ground the tails keep it upright, and as they dry and twist, they make it turn round and round on its point, which is barbed with flint; and so it bores its way into the earth, the barb holding it fast, so that it cannot be blown away by wind.

Another self-burying seed is that of one of the Cranesbills, which is nearly related to the geranium. The fruit of this little plant consists of four or five miniature arrows, which are the hardened and much lengthened carpels, each having its ovary (containing a single seed) at the lower end. At first they are fitted closely together round a central spike, and form the 
'beak' with which we are all familiar in the geranium. But when they are ripe, they separate at the lower end, and begin to twist like a corkscrew, still holding together at the tip, however, for a time. Each arrow is fringed on the inner side with short stiff hairs, and the ovary is pointed and barbed in a special manner. They are readily carried by the wind therefore, besides also clinging easily to the coats of animals; and when at last they drop singly to the ground, the barbs catch in the soil and hold them fast. The shafts of the arrows twist more and more the drier they grow, and as they twist, they turn the seed deeper and deeper into the ground.

Some seeds have many more difficulties in the way of their growing than others. For with some, it is absolutely necessary that they should be buried before they can even begin to germinate; while others, though they may be able to germinate without help or preparation of any kind, find it by no means easy to do more than make the first start.

With some, germination is an easy matter enough, all that they need being a little moisture. Such is the mustard-seed, which will sprout, and even grow for a time, on any damp surface; a piece of flannel, or even the outside of a porous earthenware jar will do, if only this is kept filled with water. Other seeds begin to shoot even before they leave the parent-plant. The seeds of a species of convolvulus put forth quite large leaves before they burst the pod; and in hot climates, the seed of the water-melon sometimes grows in like manner, within the fruit.

Brazil nuts also begin sprouting before the hard outer case in which they are enclosed shows any sign 


\section{Chances of Life}

of decay; but though they may all sprout, only one of the whole number seems to have a chance of doing more under ordinary circumstances. There, are from twelve to fifteen nuts-or, strictly speaking, seeds-in each ovary or case, which is filled with the matted roots sent out by one and all. At the lower end, where the fruit was attached to the stalk, there is a small opening, and the fortunate individual which gains possession of this exit may eventually burst the case with its roots, and so make its way into the soil. But the shell of the case is extremely hard, and, so far as has been observed, it is not often that even one single plant succeeds in freeing itself. But then, on the other hand, if the shell were less hard, none would probably ever escape the hosts of animals ready to devour them; for sprouted nuts, taken out of the case and planted, have been found to be all dug up and eaten by rats.

Such are the difficulties of the Brazil nuts; but other seeds have equal, if different, obstacles to contend with. Many, if they escape being devoured, are still quite unable to grow as long as they are left lying on the surface of the ground, especially when that surface is covered with the leaves of the parent tree.

With the exception of the sugar-maple, none of the forest-trees or the evergreens seem to have children growing up round them in Indiana. Seeds of white pines, firs, American poplars, etc., when they fall upon the scattered leaves of the parent tree, simply lie there and die; and their almost only chance of life seems to be when they fall upon some little bed of earth made by the hogs, which root about among the leaves and turn up mould while they are searching for worms.

One would not suspect hogs of doing any useful 
work of this sort; but these animals, which have been turned loose in the woods, do seem to have planted many clusters of young poplars, for the age of the trees just corresponds with the date when the pigs were first brought into the settlement.

Other animals, such as squirrels, also give similar help by digging through the leaves; and the hoofs of bullocks make deep tracks in the ground, in which any falling seeds have a fair prospect of rooting themselves.

A change deserving of notice has been wrought in some parts of the Riverina, New South Wales, solely, as it would seem, by the introduction of cattle. In the old times there were not animals enough to eat the grass down; and so, when it became ripe and dry, it was easily set alight by a chance spark from the fire of a native. The natives were, indeed, suspected of firing it on purpose, to ensure a fresh crop to tempt the kangaroos within their reach. Any seeds of eucalyptus or other trees were either killed in the conflagration or by exposure the weather, for they lay on the surface of the ground, with no animal sufficiently heavy of foot to tread them in; and it would seem that their only hope could be in chance cracks. Trees were accordingly scarce in these parts; but the scarcity evidently arose, not from want of seed, but from want of opportunity for its growth. For all now is altered: the cattle tread the seeds in, and don't, apparently, eat the young plants which spring from them; for dense forests and scrubs have arisen-not to the satisfaction - of the graziers, who would prefer grass alone. Some seeds appear to have only an occasional chance of germinating in a state of nature; for they must 
either be scalded, or scorched, or very hard frozen before they can sprout at all, and even then they cannot prosper unless they have a clear field, with no other plants to interfere with them. This is the case with the seeds of the black locust-tree, which are easily carried by the wind, and are so very hard that they may lie exposed for years without being any the worse for it, it is true, but also without being able to germinate. If they were less long-lived, they would probably die before their opportunity came. But if, when a clearing is made in the forest, the trees should be fired and the ground burnt bare, as it is sometimes, then comes their long-waited-for opportunity, and up they spring in numbers wherever the fire has passed.

The same thing is true in some degree of the Tasmanian 'fire-weed,' a thick crop of which springs up like magic wherever even a camp-fire is made, but never except where fire has passed over the ground. The plant, which is nearly related to the groundsel and cineraria, has downy seeds, which would not, of course, stand the fire; but the wind is constantly carrying them to and fro, and wherever there is a spot properly prepared for them they take immediate advantage of it. Numbers must perish while they are waiting for an opportunity which never comes; but still there are always enorgh left to take possession of any bare, burnt'space.

The seeds of a certain species of cedar could not be got to grow at all at the Cape until they had been thoroughly loiled. Such very hard-coated seeds are well protected against injury, but in a state of nature they must be dependent upon fires, frost, or perhaps on being swallowed, for the opportunity of growing. 
Other seeds, again, though they require no special preparation of themselves or the soil, are quite unable to germinate unless they get rain immediately after they have fallen, and that, too, continued for some little time.

Thus the 'soft maples' planted in the streets of Rockville, Indiana, though they have borne seed, have never succeeded in sowing themselves till within the last few years, as a single day's exposure to the hot sun is fatal both to seeds. and seedlings, and even daily watering often proves insufficient to keep the latter alive. In the wild state they spring up only in very moist or watery places, though later on they will bear transplanting to dry soil.

One year, however, there was a storm which shook down such a quantity of seed that the streets of Rockville were yellow with it. Then followed several days' rain, with sunny intervals, and the seeds sprouted everywhere, all over the streets, in the yards and the gardens, as thick as weeds - a sight never seen before.

But the cows ate those in the streets, human beings weeded out those in the gardens, and.the summer drought killed the rest; so that, of all the millions which started into life, only one clump remains, and these owe their survival to the fact that they are not only out of the reach of animals, but in a damp spot near a drain.

To be beyond the reach of animals makes, as $\mathrm{Mr}$. Darwin has pointed out, an all-important difference in the seedling's chance of life; and he mentions the case of an extensive heath near Farnham, in Surrey, part of which was enclosed, and part not. Within the enclo- 
sure multitudes of seedling trees were to be seen; outside, none. Yet they were there, plenty of them, striving, but failing, to get their heads above the heather, because perpetually browsed down by the cattle. One aged seedling, three inches high, had been making persevering but fruitless efforts for six-andtwenty years, so it seemed, from the number of its annual rings; and, but for the cattle, the heath would quickly have become a wood.

Space, as we have said, is a matter of prime importance, and the reason why tropical ferns and orchids have been so successful in establishing themselves in the islands of the Southern Ocean is not only because their seeds are plentiful and easily carried, but because, as they can grow upon other plants, they are never at a loss for vacant spots.

Bare spaces are otherwise not of frequent occurrence in nature, except on mountains, where landslips on a large or small scale are often taking place and exposing fresh surfaces. These are quickly sown with seeds either by the winds or by the birds, and hence mountain chains are very common routes by which plants travel, gradually making their way along them by easy stages. Railway embankments, too, are turned to similar account; and people are sometimes surprised to see these occupied for a time by plants which are quite strangers to the neighbourhood, the fact being that the seeds, though scattered, have never before had the luck to fall on a free space. Plants which thus gain a footing may or may not be able to keep it; they may be overpowered by the natives of the locality, but even so, if they blossom and bear fruit but once, they have gained an onward step, a fresh centre from which 
to disperse themselves, and so they may make a gradual advance.

How is it that European weeds have spread so extensively in the United States, while Australian seeds, widely and purposely scattered in New Zealand, have gained no footing?

First and chiefly because in tne one case there was a vacancy, and in the other there was none. The vacancy in America was not natural, but caused by the cutting down of forests and the dying off of the undergrowth, which was killed by sudden exposure. Of course, there were plenty of plants in America which would have stepped in and taken possession in time, but they were too far off, on the plains and prairies of the great Mississippi Valley, to do it quickly enough, and meantime the foreigners arrived. Weeds from Europe were introduced with grass seed and corn seed, and in other ways, and when the forest lands were turned into pastures and fields, these weeds had as good a chance of thriving as they had at home.

It would be a different matter if they were to arrive now, for meantime other changes have taken place which have made it easier for plants to come from the west, and they do come. New western plants migrate, it is said, almost every year into the eastern states.

And how do these new plants travel? By rail, to be sure, in accordance with the spirit of the age. They come in the coats or in the food of cattle going to market, and they take advantage of the bared railway borders, which are such excellent nursery-grounds. The great railroads run east and west, and as the prevailing winds are westerly and very strong, the plants of the west are now amply provided with the means of 
transport. The seeds also find vacant spots on which to alight, and by which they may break the journey, and finally they are transported into a climate not greatly unlike their own, so that they have much in their favour.

Plants travelling east and west have a much better chance of finding a climate to suit them than those which travel north and south, except, of course, such as cannot thrive without sea air, like the holly, which cannot live at all more than a hundred miles from the coast. But of the plants which travel north and south, those generally have the better chance which travel from a cold climate to a warmer one. Increased warmth is better borne than increased cold, and the plants of temperate latitudes have stronger and more vigorous constitutions, such as give them great advantages.

See, for instance, how they have thriven in the Pampas district of South America, in some parts of which there is hardly a native plant to be seen for miles, so completely have the new-comers ousted them. For the giant 'thistles' and the luxuriant clover already described, are not natives, but colonists. The fatherland of the artichoke family, to which this 'thistle' belongs, is on the shores of the Mediterranean, and from thence 'thistles' and clover were probably introduced by the Spaniards. And they not only found the soil and climate suitable, but, a still greater point in their favour, they found the ground very scantily occupied by native vegetation.

There had not been time to plant this corner of the world's farm thoroughly, for it had been under water until comparatively recent times-recent, geologically 
speaking, that is. And when it became dry land there were few plants and no trees at hand to colonize it.

There was abundant vegetation to the north, however, and that of the most luxuriant kind, and most of the early colonists came from there. But they were too delicate to bear well the change to such much cooler regions, and only a few managed to settle down and really flourish; so that when the Europeans came, strong and vigorous, they soon overpowered these previous colonists, which had but scantily occupied the ground, and themselves grew in a rampant manner. Any delicate new-comers arriving after such sturdy emigrants as these would naturally have no chance at all.

The air of Europe seems, indeed, to give its natives, both men and plants, a wonderful power of pushing their way and standing almost any climate, and they are to be found in almost all parts of the world.

The greater the distance to which seeds are transported, the greater usually the risk they run of meeting with some difficulty in the way of their permanent settlement.

They may find a vacant, or almost vacant, spot, and they may like the soil and even the climate, but if they are dependent upon any particular insect for fertilization they will not be able to perfect their seed without it; and if they cannot do this they can never become naturalized, and must needs in most cases die out.

The vanilla plant, introduced into the East Indies from tropical Ameriça, thrives perfectly up to a certain point, but cannot at present run wild; for being unable to fertilize itself, and finding no insects to do the work, 
it depends entirely upon man's artificial aid. In time, it is true, the difficulty might, and may, be overcome, as it has been in the case of some other plants, either by their becoming seli-fertilizing, or by the insects of their adopted country becoming accustomed to them; but, in the meantime, without man it would die out.

Of plants which require help, those are most likely to prosper whose blossoms are least peculiar in shape and most easily got at. Tubular blossoms, such even as the common clovers, require insects with trunks of some length, because their nectar is so deeply hidden that none but these can reach it. And insects do not visit flowers where there is nothing to be gained.

Composite flowers, such as the daisy, dandelion, camomile, groundsel, and many others whose blossoms grow together in flat heads, are easily fertilized by almost any insects; and what with this advantage and the further one, that so many of the family have downy seeds easily carried by the wind, composites are among the most thriving and successful emigrants. 


\section{$\mathbf{x X}$.}

\section{FRIENDS AND FOES}

From one point of view all animals, with the exception of a few insects, may be looked upon as enemies of the plant-world, since they either themselves feed upon plants, or live on others who do. But this would be a very partial view of the matter, even where the destruction is complete; for it is a positive benefit to the race that the greater number of seedlings, as well as seeds, should be devoured, or otherwise removed, since without this thinning of their numbers none could come to perfection.

Linnæus calculated that any one annual which produced but two perfect seeds-its descendants doing the same every year-would have increased to a million in the course of twenty years. Now all annuals do considerably more than this as a rule; and as they do not increase at an alarming rate, it is evident that their existence must in many instances be cut short, at one time or other of their career.

Plants have many and various enemies which attack them at different stages of their lives, but it is chiefly while they are seedlings that they are altogether exterminated, and this they are wholesale. Out of 357 seedling-weeds growing together without any crowding 
in a small plot of ground, Mr. Darwin found that 295 were destroyed, mainly by slugs and insects.

From the point of view of the destroyed-the victims - these creatures were undoubtedly foes; but from that of the survivors they were as certainly friends, for the latter would grow up all the more vigorous for having plenty of space.

But if slugs and insects were allowed to multiply without check, they would become foes and nothing else, and would end by eating up every green thing. There are checks upon their increase, however; and besides this, many plants are to some extent protected against them, as otherwise certain species might be exterminated altogether.

Plants like the grasses, which bear vast quantities of seed, are protected by their very numbers, and can well afford to be eaten, if but a small proportion be allowed to perfect and disperse their seed; but others, less prolific, are guarded in various ways, being made either disagreeable or difficult of approach.

The whole of the Gentian order, for example, are so extremely bitter, that they are seldom touched even by caterpillars; and the Eschscholtzia, which is of another order, is also so intensely bitter as to be more avoided by slugs and the like than any other plant, it is said. Even Eschscholtzias are, however, a good deal bitten at times, probably by earwigs, but this may be owing to drought and consequent scarcity of vegetable matter, as it is not a common occurrence. It is at least something to be proof against certain classes of enemies; and no plants are defended against all, since they are intended to be eaten, though not exterminated. 
The bark of oaks, elms and willows, is made sufficiently unpleasant to most animals by the presence of tannin; and ferns contain so much of this that few animals care to eat them, though they have their own particular caterpillars.

Many plants are not merely disagreeable, but even poisonous to mammals, though birds may eat the seeds, and insects the leaves, with impunity; and others again are of such a biting flavour as to raise blisters on the tongue or skin. Some members of the buttercup family are of this acrid nature, and the buttercup itself is said to be avoided by cattle; but on the other hand, the deadly nightshade, which is fatal to man, is eaten with impunity by the rabbit.

The Asclepias gigantea of the desert is so deadly that the least drop of the poisonous milk contained in its leaves and stem causes total blindness if it touches the eye; and even those who cut the plant for firewood must beware of so much as touching their eyes afterwards, since a merely accidental rub may deprive them of sight.

One would suppose, therefore, that the asclepias was so amply protected as to have no enemy at all; yet there is one upon which its deadliness makes no impression whatever; and this, the goat, devours it greedily, though all other animals refuse and avoid it.

Goats are indeed the most omnivorous and most destructive of animals, and very few plants, or even trees, are safe from them. Neither the thorns of the prickly pear, nor the flinty 'needles' of young pines and firs afford any sufficient protection against them; and yet even the goat has its preferences, and is said to refuse lettuce, while it will eat cabbage. 
Probably each plant has its own appropriate enemy -really a friend to the race-whose office it is to check its undue multiplication. And one reason why plants introduced into other lands sometimes run riot there, and even extirpate the natives, is just this, that they are foreigners, and that there is at first no animal to keep them within bounds. If there had been some common bird to eat the seeds of the wild artichoke or 'thistle,' for instance, when first it reached South America, it could not have gained the upper hand so entirely as it has done. At present the plant itself is eaten to some extent by horses and mules, but only when other forage is scarce, as its spiny leaves are a great protection, and make it actually formidable to most quadrupeds. Goats might manage it, but otherwise it seems that birds are what are wanted to keep it in check. Eventually, however, man may prove to be its 'appropriate enemy,' and will cut and stack it, as he has begun to do with its cousin the Scotch thistle in Victoria, which proves excellent winter food for cows, when thus treated, as the spines lose their stiffness when dried.

Foreign plants are, however, sometimes at a disadvantage when introduced into a new country, as they may meet with enemies unknown in their native land, and against which, therefore, they are undefended. But generally speaking, foreigners are much let alone at first, for most animals are suspicious of anything new and unfamiliar; and nearly all, especially of the mammalia, far surpass us in keenness of scent. They 'live in a world of odours,' most of them with their noses near the ground, always on the qui vive to notice anything strange; and gener- 
ally speaking, what is new and strange that they mistrust and avoid.

This fact was strikingly illustrated on one occasion by a bear in the Jardin des Plantes, one of certain victims whom it was found necessary to despatch. A bun dipped in prussic acid was offered to this bear, and was graciously accepted; but Bruin quickly decided that there was something not quite satisfactory about it. He was familiar with buns, but this was not an ordinary bun, and therefore might be mischievous, so he dropped it into the water and prudently allowed it to soak until the strange smell was gone.

In a similar way, cattle imported and turned out to feed in strange pastures are said usually to avoid poisonous plants, not because they are poisonous, but because they are strange, and therefore to be doubted.

When they have attained a fair size most plants can well afford to have some of their leaves eaten; but if no blossoms are left the plant dies without successors, and this, in many cases at least, is not to be desired. Accordingly we find that, as a rule, blossoms are avoided by all animals, including even caterpillars, which would rather die of hunger than eat the blossom of the very plant whose leaves are their favourite food. Earwigs, indeed, are less particular, and are given to biting dahlias; and whatever wild rabbits may do, tame ones often begin with the blossom of poppies and succory, as if it were a choice morsel.

Plants are protected against indiscriminate consumption in a variety of ways : by being unpleasant in flavour or poisonous, by the toughness and hardness of their foliage, by prickles and by thorns, sometimes 
of formidable size, and by hairs, whether sticky or stinging.

Certain caterpillars are proof against the stings of the nettle; but as a rule this plant is very carefully let alone; and such grasses and sedges as are unpleasantly wiry are also avoided by cattle, unless they are driven to eat them by hunger. The Alpine fescue-grass is so extremely stiff that its needle-like points prick the noses of unwary animals, and no doubt in this way it escapes being eaten; but, on the other hand, it is exterminated wholesale by the herdsmen of the Alps, who burn it where it occurs in large quantities. In the ordinary course of nature, however, where man does not interfere, it is no doubt very effectually protected.

Prickles and thorns are among the most efficient guards a plant can have, and are often positively formidable weapons of defence. One has only to think of the strong, stout thorns of the rose, and the long, sharp ones of the gooseberry-bush to realize that it would be dangerous for any animal to attempt to make a meal of them. The sharp little prickles of the raspberry, too, must make it, one would think, anything but pleasant eating to most creatures, though donkeys will munch raspberry-canes as well as thistles.

But all these small thorns, sharply as they can wound, are a mere trifle compared with those which protect many foreign plants and trees until they have grown beyond the reach of cattle. There is a palm, for instance, in Ceylon, whose trunk is covered for the first six or eight feet with a coating of thorns so closely set together that the bark is hardly visible; and there is also a climbing plant, very common in the jungles, 
which is thickly studded with knobs, each ending in a thorn as large and sharp as the bill of a sparrow-hawk. Even the tough hide of the elephant is not proof against the 'jungle nail,' or 'elephant thorn,' an acacia, whose lancet-like spines-which frequently grow, not singly, but in branching clusters-make any forest where it abounds absolutely impassable.

The buffalo thorn, or bull's horn acacia, is interesting in another way. Its trunk and branches are beset by strong thorns two or three inches long and as sharp as needles, which grow in pairs, and are shaped just like horns. But, as if this were not enough to ensure its safety, the tree maintains as well a standing army, which keeps off all aggressors, large and small, at least during the wet season, for then every thorn is tenanted by ants, which rush out and sting severely any animal venturing to touch the tree.

Caterpillars, which might make their way between the thorns without injury, have no chance against the ants, and even their own rapacious relations, the leafcutting ants, are completely batilled.

The ants of the buffalo thorn are not to be found in the forest, or, indeed, anywhere except on this particular acacia, which belongs especially to the dry plains or savannahs of Central America. When the 'horns' are first put forth they are filled with a soft, sweetish pulp, which the ants hollow out, burrowing between the partition which separates them, and thus making a single dwelling of each pair. The thorns do not suffer in any way from this treatment, and continue to grow until they have reached their full size.

But the ants do not frequent the trees for the sake of comfortable lodgings merely. They want, and find, 


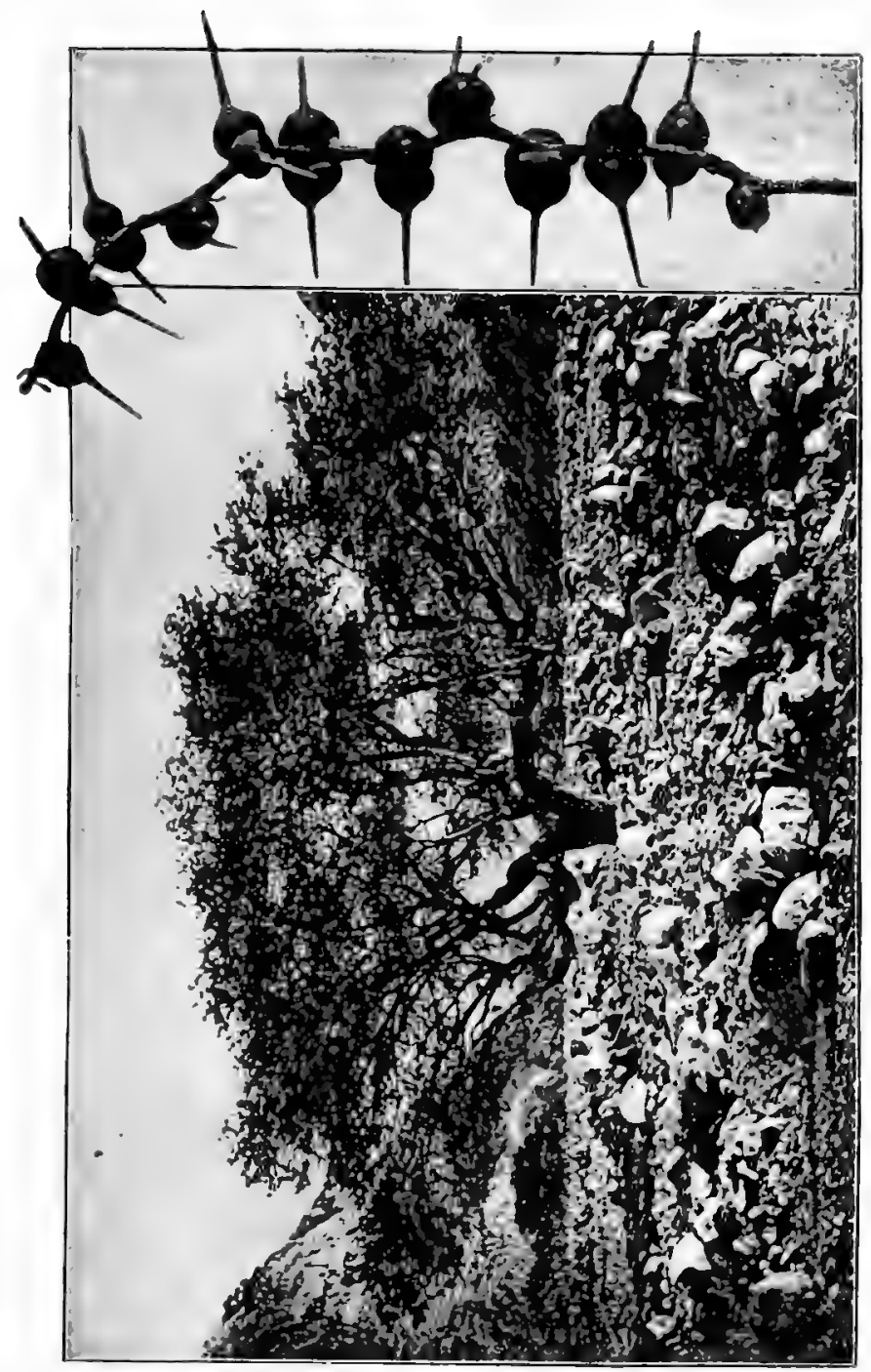



Food as well. At the base of each pair of young leaflets there is a gland, which contains a liquid something like honey; and, besides this, the young leaves bear what are described as 'minute golden pears,' small, sweet protuberances, which ripen in succession and need constant examination. These two delicacies, their sole food, the ants are always ready to defend, and during the wet season hundreds of them may be seen running about on the young leaves, which are thus kept clear of all enemies for some time after they unfold.

Many other plants (among them being many orchids and passion flowers) are similarly defended in the tropics of both east and west, the ants rushing out and biting the finger of anyone touching them; and though they have their disadvantages, when, as in the case of the trumpet-tree, they choose to keep 'cows ' -scale insects which suck the juices of the hollow stem within which they live-still, it is evident. that in other instances their guardianship is not only valuable, but positively necessary. This was clearly proved in the case of some acacias raised in a garden in St. Domingo, Nicaragua, which were cut to pieces by the parasol ant simply for lack of their natural defenders. For St. Domingo is situated in the midst of forests, and the ants which protect the acacia are never found within their precincts, or, indeed, anywhere but on the savannahs.

This parasol, or leaf-cutting ant, is one of the worst enemies of vegetation in tropical America, where it is catled the curse of the country, owing to the damage which it inflicts on the crops. It may be a friend in disguise to the wild crops, by preventing their too 
great increase, and its services in the past in burrowing and tunnelling and in adding to the organic matter of the soil must not be forgotten; but at the present day the farmer can hardly look upon it as other than an enemy. It is the cultivated plants of foreign origin which it especially attacks, for very many of the natives are protected against it in one way or other, while the foreigners are undefended-a good example of the risks sometimes run in this way by colonists.

The Indians defend their trees by a very simple device, that of fastening thick wisps of grass with the sharp points turned downwards round their stems. The multitude of points quite baffles the ants, and prevents their climbing further up. Orange-growers plant their young trees in the centre of ring-shaped earthen vessels, which are kept filled with water, and answer one of the purposes of the natural 'basins ' of the teasel and other similar plants.

In some parts of America orange-trees have run wild, and have formed thickets, in spite of the ants; but, generally speaking, all the species of the citron family-the orange, lemon, etc.-except the lime, would be very quickly destroyed if they were left without the help and protection of man. The lime has run wild, and seems to be less liked by the ants than the orange and lemon, whose leaves they 'cut up into sixpences ' when they have the opportunity, leaving nothing but rags behind them. They are terrible enemies to young plantations, nurseries, and gardens; but they greatly fear the small ants which protect certain plants.

The agricultural ant of Texas occupies a different position from that of the leaf-cutter, for she is really 
an agriculturist on her own account, and the only one in the animal world, so far as we know. She is no more an enemy to vegetation, therefore, than the farmer who cuts down 'bush' that he may grow wheat, for she does a precisely similar thing.

It is unfortunate for the farmer, of course, when her 'bush' chances to be his corn or sweet potatoes, which she cuts down as ruthlessly as he does scrub; or when she decides that his young fruit-trees must be stripped of their leaves because they keep off too much of the sunshine from her domain. But she does not plunder his crops for food, and she does grow and tend and reap crops of her own as regularly and carefully as he does himself.

For this purpose, at least partly, she makes circular clearings some ten or twelve feet in diameter, sometimes in rough, wild pasture, sometimes in the middle of the farmer's fields; and she clears away his cotton, or corn, just as impartially as she does the weeds, for to her they are weeds. Considering her size, her labours are truly herculean, for she cuts through, with her teeth, stems as thick as a thumb; and by dint of sawing, twisting, pulling, biting, she clears everything away, no matter how rank the growth. And this is not all, for the space is not only cleared once, but kept clear till the 'ant-corn' has ripened-a matter involving no small labour where it is surrounded by a dense growth of weeds always ready to encroach.

The crop consists of a tall, yellowish grass, and not so much as a blade of any other species is allowed among it. It ripens about the end of June, when the seed is cut from the stalk and carefully stored. That which falls of itself to the ground is not harvested, and 
it is probably from this that the next year's crop springs, though some have declared that the ants actually sow as well as reap. Harvest over, the dry stubble is cut and cleared away, and weeds are left to grow as they will during winter, the work of cutting them down beginning vigorously again in spring.

These ants live chiefly on grass seeds, which they gather from a distance as well as from the home crop; but though they do not steal food from the farmer, they inflict much injury on his fields, and destroy many an acre of produce, no amount of ploughing being sufficient to drive them away.

It is impossible even to enumerate the many animals which feed upon plants, and, when allowed to increase unduly, become the enemies instead of the friends of vegetation, not merely checking overcrowding, but destroying wholesale.

We cannot attempt any description of the devastations caused by locusts, one of whom is reported by Mahomet to have remarked, "We are the army of the great God; we produce ninety-nine eggs. If the hundred were complete, we should consume the whole earth and all that is in it.' Nor can we tell of the ravages of the American crickets, which eat up a whole crop of maize in a night; or of the caterpillars, which would completely destroy the tobacco plantations if not constantly picked off leaf by leaf; or of the minute beetles, whose grubs, penetrating between wood and bark, destroyed in I780 and the following years a million fir-trees in the Harz mountains and Switzerland, 50,000 trees, chiefly oaks, more recently in the Bois de Vincennes, and are causing avenues of fine elms to disappear in the north of France. Green fly, 


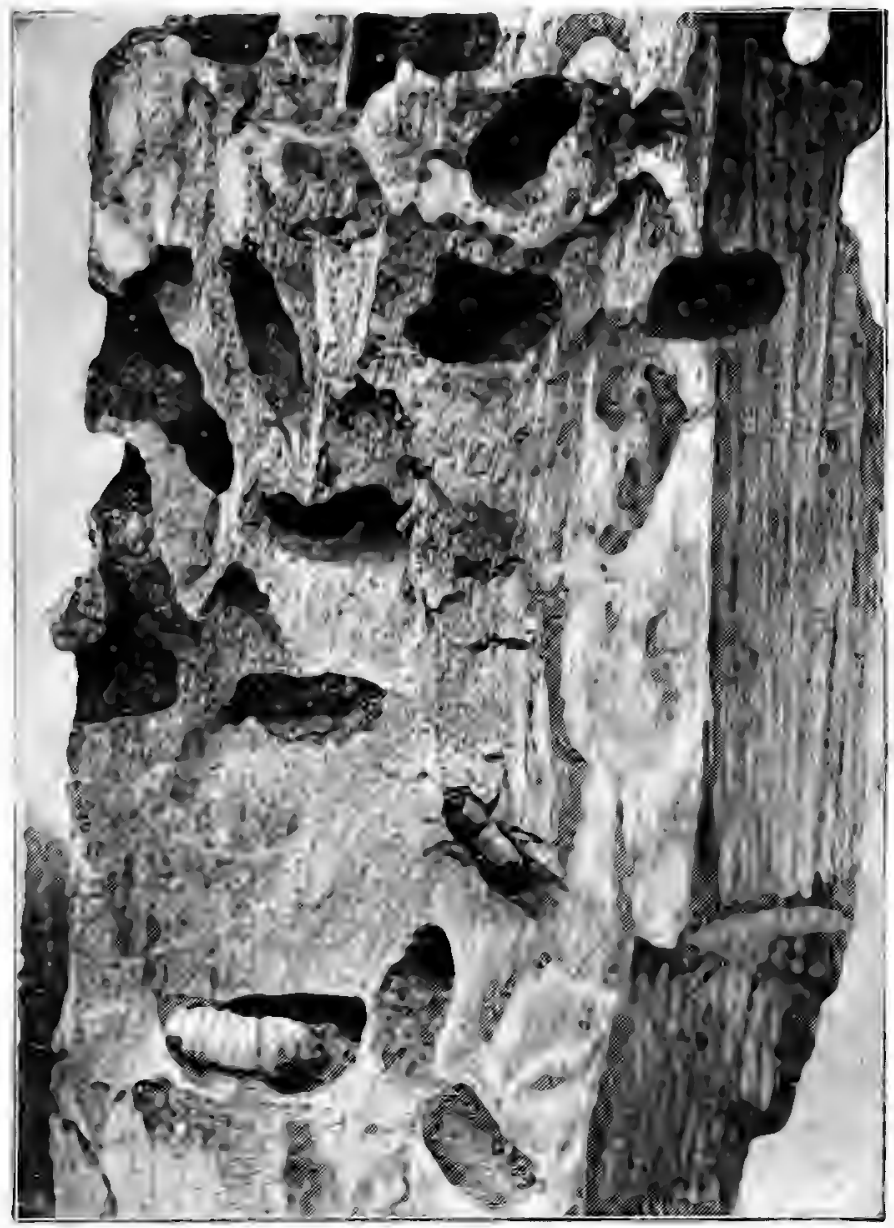



scale insects, slugs, wireworm, grubs, and the various other plagues known to the gardener and agriculturist must also be passed over, and we must go on to consider by what natural means these various creatures are kept in check and prevented from becoming positive enemies to all vegetation, instead of merely thinning the ranks, to the advantage of the survivors.

For, when one reads of flights of butterflies which take days and weeks to pass, of armies of caterpillars which stop the progress of railway trains, and of dense clouds of locusts several miles long, it is quite evident that unless their increase were restricted by some very efficient means they would all more than justify the locust's boast, and leave not so much as a blade of grass.

Man is utterly unable to cope with them by any means at his present disposal, and when he interferes with nature's way of keeping them within bounds, he learns by hard experience his own utter helplessness, and often not till then.

In the Middle Ages people seem to have had the feeling that they ought to be able to control grubs and the like, by the mere word of command, and the chroniclers of the time often give reports of the lawsuits instituted against these creatures. In 1479 , for example, the canton of Berne was troubled with such an overwhelming plague of grubs that the Council petitioned the Archbishop of Lausanne to banish them, and the priests were authorized by him to do so. In accordance with the usual custom on these occasions, advocates were appointed for both parties-the grubs and the people. A written summons was issued; the grubs were cited to appear, and some were brought 
into court; but they were not fairly treated, as the advocate assigned to them was no longer living, and judgment was given against them in these terms: 'We, the Archbishop of Lausanne, condemn and excommunicate ye obnoxious worms and grubs, that nothing shall be left of ye except such parts as can be useful to man.'

No steps seem to have been taken, however, to give effect to the sentence, and the grubs obstinately ignored it.

But if the Council could have imported a few hundreds of small birds, they would most likely have been quickly rid of the plague; for these, and these alone, are the natural and most effectual provision for keeping the numbers of grubs, caterpillars, and the like within their proper limits. 


\section{XXI.}

NATURE'S MILITIA

'IF nature's militia, the army of birds, be killed, it will be impossible to find a substitute for their faithful guardianship.'

'Birds are nature's soldiers, and keep in subjection the inferior animals. Their other uses are scarcely worthy of notice compared with their labours in the destruction of insects.'

Wise words, which cannot be too often insisted on; for though we are beginning to wake up to the immense value of the feathered tribes as guardians of our fields, we are still only beginning; and, unfortunately, farmers and gardeners, the very persons most interested, are precisely those whom it is most difficult to arouse.

They know well enough, of course, that insects, generally speaking, are their enemies; but they do not. yet recognise, as they ought, that the birds are their friends, who, if only let alone, would save the crops from these marauders.

A plague of grubs finds us, in fact, just as helpless as our forefathers in the Middle Ages, and almost more hopeless, for we no longer believe in trying to 'banish' our enemies, and we have not yet discovered any more 
effectual means of dealing with them. When the infliction comes, we talk mysteriously of 'blight' and 'weather'; and it seldom occurs to us to connect the increase of grubs with the destruction of birds, even though we must know, as a matter of fact, that the latter live mainly upon the former, and that therefore for every bird killed, so many grubs must be left alive.

However, as before said, we are beginning to wake up, and in some cases the awakening has been so rude that further slumbers are almost impossible.

It is now some thirty years since piteous complaints were rife in Germany and Switzerland of the alarming increase in the number of destructive insects, which made their appearance in overwhelming swarms, and inflicted the greatest injury on the fields. And at last it occurred to the authorities that insects had multiplied because birds had to so large an extent vanished. The ' militia' had, in fact, been either killed off or driven away; they had been destroyed in the most insane manner, in ignorance and sheer wantonness; and also they had been 'improved ' away by the spread of agriculture. In whatsoever way it had come to pass, the result was the same-there were fewer birds, there were more grubs; and as the latter increase mucil more rapidly than the former, the prospect was a dismal one. The land was being devoured.

And it was devoured, partly at least, because more had been taken into cultivation. For woods and thickets and groups of trees had been cut down to make way for fields; and land being precious, hedges were considered an unnecessary extravagance. There are, of course, still extensive woods and forests in 
Germany, but one may travel many a long mile without seeing any of the hedgerows with which he is familiar in England. The fields are for the most part one large expanse, without any bordering of trees or bushes.

But it is quite possible to be too thrifty. If every foot of land is occupied by crops, where are the birds to build their nests? Most of them need more shelter than is to be found upon the ground, and if they cannot find it in one place they are obliged to look for it in another. If the farmer will not spare them a few trees and bushes, they are compelled to desert his fields and leave them unprotected.

But this is not all. Grubs, as well as birds, find shelter in the hedges; and not only shelter, but food. When the birds are driven away, therefore, the grubs are driven away, too; but, alas! while the birds migrate to a distance, the grubs are only driven out of the bushes and hedge-plants, where they are comparatively harmless, into fields, orchards, and gardens, where, in the absence of the 'militia,' they run riot as they will.

We see, indeed, the '... hedges all alive With birds and gnats, and large white butterflies, Which look as if the May-flower had caught life, And palpitated forth upon the wind.'

We see; but perhaps we hardly realize that if the hedge be cut down its population will find quarters elsewhere; and that while the birds betake themselves to the nearest thicket, perhaps some distance off, the butterflies and moths will simply flit a few yards, many of them being quite content to supply their offspring with cultivated plants when they cannot get wild ones. Somewhere or other they must and will lay their eggs 
-if not in the hedgerow, then in the garden; and the grub of the white butterfly is, as we all know, able to make quite a decent living upon cabbage-leaves.

That there should be trees and bushes, with their usual undergrowth of wild plants, in the neighbourhood of cultivated land is therefore a double advantage : the grubs are supplied with food, and kept away from the crops; and the birds, the grubs' natural enemies, are attracted, and keep down their numbers.

But the larger the area of land cultivated, the smaller the space left to nature; the more fields, the fewer thickets; the fewer wild crops to feed the grubs, the fewer nesting-places for the birds. And thus the mere fact that more land had been taken into cultivation would alone be enough to account, in some degree, for the marked increase in the numbers of Germany's insect enemies.

But this was not all, or nearly all. Not only had the grubs been driven into the fields, and the birds driven out of them, but the latter had been killed wholesale. Government keepers were actually under orders to destroy the woodpeckers, whose special office it is to rid the trees of beetle-grubs, and the cuckoos, which devour the hairy caterpillars which no other birds will touch, and so on.

And the Germans have not been the only, or even the chief, offenders. They have killed their own birds, and have suffered for it. But the Italians have done worse; for they have waged deadly war upon the birds which are the common property of Europe. They have a perfect mania for slaughtering small, insect-eating birds, and unhappily they have special opportunities of gratifying it, as large flocks of migrants pass through 
this, to them inhospitable land, every year on their way to and from the south. Considering the way in which they were received, one wonders why they did not choose some other route; but the force of habit seems to be too strong for them, and their ranks have been thinned year after year in the most fatal manner. Not even the swallows were allowed to pass unmolested; for to catch them, by floating hooks baited with flies in the air, seems to have been considered a particularly fascinating pastime.

For months the chief delight of the population was in catching birds, and several million were killed regularly each autumn in the neighbourhood of Verona. alone. Larks are among the most useful of the insect-eating birds, and so entirely harmless that even the farmer has no fault to find with them. Yet neither their usefulness nor their harmlessness were sufficient to save them from persecution. Unluckily for themselves, and we may add, for Europe, they had chosen Sicily as one of the places at which to break their journey, and they could hardly have done worse. The Sicilians knew when to expect them, for they came regularly every autumn, nearly a million arriving daily for ten days, and they gave them a warm reception. Hundreds of the population went out to meet them, armed with guns, and there was a regular battue. How many were slain history does not say, but the numbers must have been very great. They did not die unavenged, however; for every lark killed left so many more insects to ravage the crops; and when people woke up enough-to put two and two together, and to connect the plagues of insects with the destruction of the 'militia' which should have 
kept them under, measures were taken to check the persecution.

To some extent birds are now protected in Europe; but we do not seem to have learnt our lesson even yet, for a cry that the birds are being exterminated is now making itself heard in Asia, Africa, and America. The war carried on against them in India, is already having very serious results; the swamps and marshes of Florida are being depopulated; Guinea is being despoiled of its birds of paradise, and birds of bright plumage are becoming more and more rare everywhere all over the world.

And why all this slaughter? Not because there is a famine in the land, and the birds are needed for food; not even for the sake of 'sport'; but because the fashionable ladies of Paris, London, and Vienna require the sacrifice of at least thirty million birds every year, that they may decorate themselves with feathers.

In India, which furnishes hundreds of thousands of skins every year, insect life is rampant beyond anything that we have experience of, and is 'only kept within bounds by the utmost effort of all the checks provided by nature.' The 'patient, unpaid labour of the useful small birds' is the one only remedy for the insect epidemics to which the empire is liable, and it is sheer madness to allow them to be killed off.

We must hope that the 'Indian Wild Birds' Protection Act' will at least check the slaughter, for, if it be allowed to go on, it can have but one result, and the birds will be avenged here, as they have already been in Europe. When once they are gone, no artificial substitutes can by any possibility make up for them. One may syringe the fruit-trees, cover the gooseberry- 
bushes with road-dust, pay regiments of school-children to gather grubs by the quart, try in fact all the various expedients which have ever been resorted to, and yet find in the end that it is simply impossible to overtake the damage caused by the absence of the birds, with their marvellously keen sight and extraordinary appetites.

Let us consider for a moment one single fact. $\mathrm{Mr}$. Darwin found that scarcely more than a sixth part of his seedlings survived the attacks of slugs, snails, and insects. But what does this mean? Only this, that if the numbers of the enemy had been increased by so much as a sixth, there would have been no seedlings left alive at all.

One additional slug or caterpillar to every five would positively have destroyed the whole crop, even in England, where there are many hedgerows and many birds, and where insect life is not anything like as abundant as it is in warmer latitudes, such, for instance, as certain parts of the United States, where railwaytrains are from time to time brought to a standstill by armies of caterpillars or grasshoppers $a$ foot deep.

It is difficult to realize, or even to form a faint idea of, the numbers of insects, or the extraordinary rapidity with which they multiply; for the figures which are so easily quoted are "like the distances of the heavenly bodies, too great for comprehension: nothing equals them except the incredible appetites of the insecteating birds.'

Take, for example, the common house-fly, one of which is said to have $21,000,000$ descendants in the sourse of a single summer, or would have, if all 
were allowed to live. That we do not have a yearly plague of flies is due solely to the vigilance of the birds.

Look, again, at the country about Torgau on the Elbe, where, a few years ago, birds were so scarce that a large sum was spent yearly on the destruction of grubs and caterpillars, to save the forest from utter ruin; yet all that human ingenuity could devise was quite inadequate; 800 acres of fir were entirely stripped one year, and at the same time so much grass was devoured that it was necessary to import hay. In Hesse, too, all efforts to deal with a similar plague of caterpillars were equally vain; and it was noticed that they were especially destructive where there were few trees. to divert their attention and to attract the birds.

The shrew-mouse, hedgehog, mole, lizard, frog, toad, bat, and some of the beetles, are all excellent insecthunters, and the wasp and ichneumon-fly do good work against caterpillars. But though their services are valuable, the birds do more than all besides, each kind in its own especial department. Some pick. insects, or their eggs, from the leaves, others from the bark; some dig them and their chrysalids from the earth, others catch them as they fly.

And what quantities they devour! for their digestion is very rapid, and whereas human beings require only a few ounces of dry food a day, they swallow a quantity which is equal to their own weight. Think of it! - the weight of a bird in insects; green flies, for instance.

One redstart, kept in a room, has been known to eat 600 flies in an hour; and one blackcap has cleared 


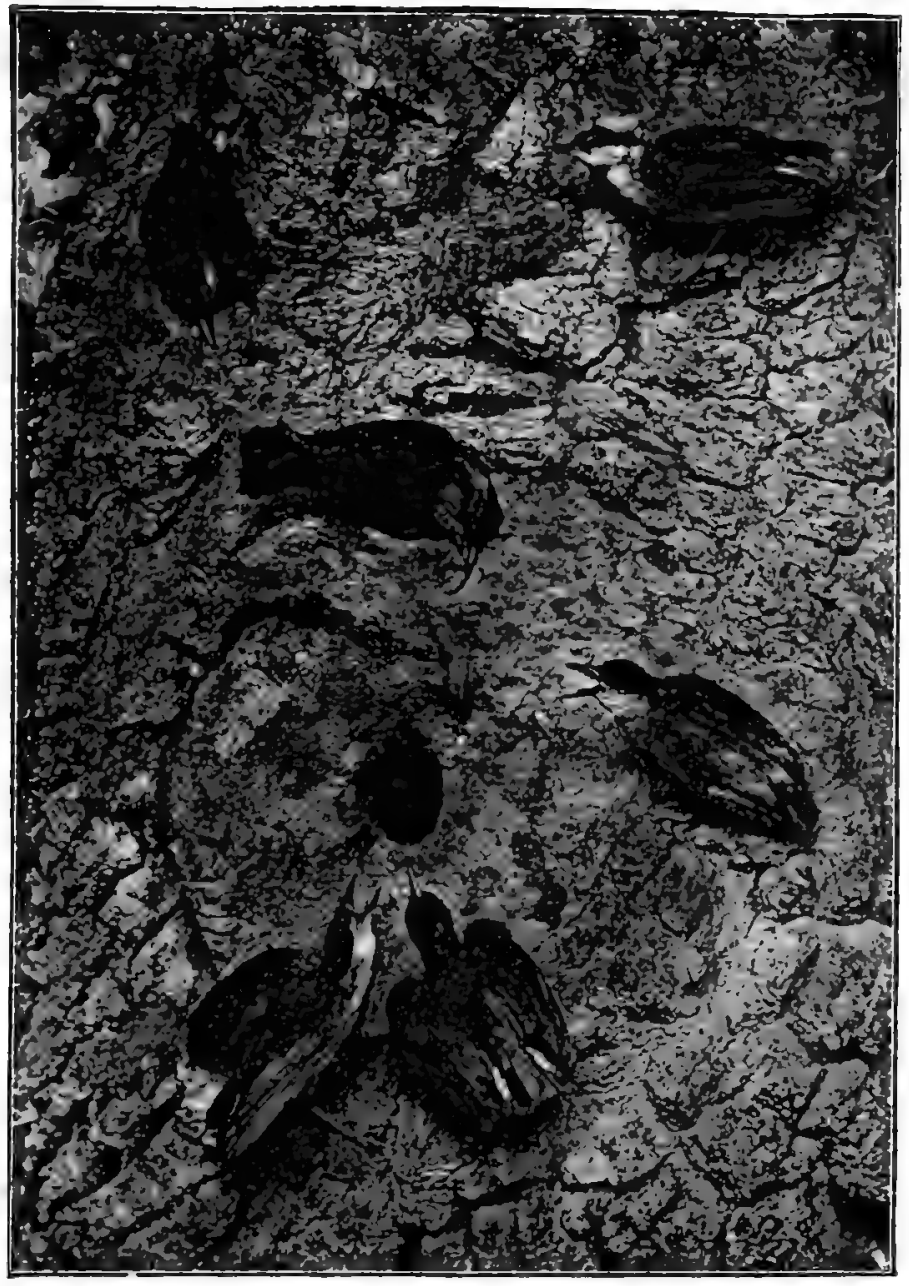



about 2,000 green-fly from the rose-trees in a greenhouse in the course of a few hours.

The titmouse is another most active little bird, constantly engaged in the hunt for food, creeping into rolled-up leaves, and devouring by the thousand eggs which would produce many more hairy caterpillars than the cuckoos could dispose of. As an example of the invaluable services which it renders in effecting a clearance of these, we may mention a garden whose trees one year were entirely stripped by caterpillars. In the autumn millions of eggs were seen on the trunks and branches, and an attempt was made to clear them off at considerable expense, but was soon given up as hopeless. It seems strange that man should have to acknowledge himself defeated by anything so fragile as a butterfly, but so it was. However, the birds came to the rescue. Twenty pair of titmice, as well as some wrens, came and built in the garden the following spring, and that summer the trees suffered much less. By the year after, the plague was so thoroughly under control that they remained in full leaf the whole season.

The wren, like the titmouse, is perpetually eating, and feeds her young thirty-six times in an hour; the cuckoo, too, eats all day long, every five minutes or so, and devours about I70 good-sized caterpillars in the day; and as each of these caterpillars, if allowed to reach the butterfly state, might lay some 500 eggs, every cuckoo rids us of a possible 85,000 odd caterpillars daily!

And the work goes on vigorously in winter, as well as in spring and in summer, for, with all the vigilance of the birds, caterpillars and grubs innumerable escape 
and pass into the chrysalis state, which they spend - as much of it as they are allowed-in cracks and crannies, in sheltered nooks, on twigs and trunks of trees, on palings and walls, and in the ground. These supply food to the many insect-eating birds which do not migrate; and but for the unceasing labours of these stay-at-homes we should be overrun with insects in the spring, in spite of all that is done in the summer; for each chrysalis devoured saves us from some hundreds of grubs or caterpillars later on.

From all this it must be sufficiently plain that without the birds every green thing would be devoured. Yet to talk of the 'patient, unpaid labour' of the birds is a trifle absurd, for their 'labour' is its own reward, and consists in picking up food for themselves and their families; and it is incessant merely because they and their nestlings are always hungry-a most fortunate provision of nature ; for does even the most ardent of bird-lovers flatter himself that they would devote themselves to clearing his trees of grubs if they lost their appetites?

If anyone needs proof of what would certainly follow the extermination of the birds, he need only look at the island of Jamaica, where they are at present very scarce, having been killed off, chiefly to adorn ladies' bonnets. It must be remembered, too, that while birds multiply only by tens, insects increase by hundreds, by thousands, and by tens of thousands, in a single season, so that although the birds are now protected in Jamaica it will be long before the loss is made good. Meantime they are terribly avenged; for the island suffers from a disgusting and grievous plague of ticks imported with 
cattle, which swarn upon every leaf and blade of grass, except on the higher bills.

To make matters worse, too, the mongoose was imported a few years ago, and, like sundry other importations, has proved a dismal failure. The idea was that it would kill off the rats which so swarmed in the sugar-plantations as to be a great nuisance to the planters. And the mongoose began well; but when its numbers had increased, as they did enormously, it began to vary its diet of rats by eating the eggs of such birds as build on the ground, and then it went on to eat the birds themselves, and even poultry, besides killing off all the lizards and snakes, which were not only quite harmless but most useful as insect-eaters. In one way and another, the ticks were thus delivered from their natural enemies, and now have things pretty much their own way, and seem likely to have for some time to come.

Jamaica has given birds for ticks, and the Isle of Bourbon made an almost worse exchange, for it gave birds for grasshoppers. A price was put upon the heads of the swallows, and they disappeared; but in their stead came grasshoppers in such overwhelming swarms that they took entire possession of the fields and devoured everything. And the mischief did not stop here-there was worse to follow; for when the green things were destroyed, the island became a prey to scorching, biting drought. So dangerous is it to interfere with the wise arrangements of nature, so utterly impossible for any human contrivances to take their place.

In sandy deserts, birds are naturally almost wanting, for there are few trees or bushes, and little vegetation. 
of any kind, either to give them shelter or to need their protection. But it is here that the very worst of insectplagues are hatched. Locusts lay their eggs in the hot sand, and there seems to be no appropriate enemy on the spot to reduce their numbers. As soon as tiey take to flight, indeed, which they are compelled to do for the sake of food, they are followed and set upon by flocks of birds, but their numbers are then so large that they are masters of the situation, and devastate any district upon which they settle.

It is, nowever, only when they come down upon cultivated lands that we hear of their ravages, and since, as before said, cultivation in most cases diminishes the number of the trees and with them of the birds, it is perhaps a question whether, in a state of nature, the birds might not even then be fairly a match for them. They seem to be so, at all events, in the Khivan oasis of Turkestan; for though the locusts arrive there in clouds, often several miles long, they are at once set upon by multitudes of small birds. But then Khiva abounds both in birds and in planted groves, and its inhabitants apparently know better than some Europeans the value of their defenders.

However, there are probably few people in the present day who would seriously dispute the value of such birds as live upon insects only. It is when we come to mixed feeders, such as the sparrow and the rook, that opinions are divided.

A fierce battle rages round the sparrow. He is accused of stealing corn and fruit, and of. heartlessly destroying crocuses for the sake of the unformed seeds. In some districts he is persecuted without 
mercy and leads the life of an outlaw. Sparrow clubs, encouraged by the farmers, kill him by the thousand and destroy his nests.

That he is mischievous no one can deny, and that he sometimes does serious damage must be admitted even by his warmest admirers. But if we cannot have our crops without paying toll upon them, it seems better to share with the sparrow than lose all to the grub-the only choice, according to some, which lies before us.

The sparrow's friends, the naturalists, say that each sparrow actually saves a bushel of corn, for he himself lives for nine months of the year almost entirely on grubs, while his family eat absolutely nothing but insect food as long as they remain in the nest. One pair of sparrows, it is said, take 4,300 grubs or other insects to their young in the course of a week; and that they are the deadly enemies of the cockchafers, which have done a million pounds' worth of damage to the crops in Normandy, is evident, for the wing-cases of 700 cockchafers have been found under a single nest.

Finally, we are told that caterpillars to the number of $354,375,000,000$ are eaten by sparrows every year, and that while we see the damage which the sparrow does during three months of the year, we do not see how hard he works for us during the other nine, or what far greater damage he averts from us. We grudge his wages, in fact, simply because we do not understand how vast are his services.

But a few facts are worth many arguments. Let us see what has followed the expulsion of the sparrow in one or two cases. Frederick the Great of Prussia waged war against the sparrow, and-he was defeated, 
ignominiously defeated, and he had the good sense to own it. The king liked cherries, and the birds liked them too; and he gave orders that the sparrows should be driven away, exterminated, got rid of. And he was so well obeyed, that in two years' time there was not a sparrow left in the neighbourhood. So far he was the victor, for he had certainly vanquished the birds; but he had overreached himself, for instead of having more cherries he had none!

There were no cherries at all that year; worse still, there was no fruit of any kind, but in its stead a hideous crop of caterpillars, which had stripped the trees of their leaves. Other birds besides sparrows, of course, eat caterpillars, but the means used to get rid of the sparrows had frightened these others away also. The orchards had been deprived of their guardians, and the enemy had taken possession, and before matters could be set right sparrows had to be imported, at considerable expense; for they would never, it is said, have returned of their own accord, as they are not given to wandering.

Take another instance. In Hungary, as elsewhere, sparrows are given to stealing corn, and they were outlawed in consequence. But in a short time it was found that the people were in danger of perishing by famine, owing to the frightful increase of insect-plagues. The decree against the sparrows was hastily revoked, for they, and they only, could keep down the beetles, and the thousand winged insects of the lowlands.

Then again, in the spring and early summer of 1888 , there was an almost unprecedented attack of maggots in the Kentish orchards, and in many cases the nut and apple crops were grievously damaged, if not 
destroyed. Vigorous efforts were made to fight the enemy, but all was in vain, and the terrible and unusual increase in their numbers was ascribed by some of the wiser farmers to the wholesale slaughter of sparrows.

Of course sparrows, as well as chaffinches, bullfinches, linnets and others, eat some amount of grain (though not necessarily the farmer's), especially when insects are scarce; and sometimes, no doubt, they take more fruit than the owner cares to spare them. Nothing is perfect; but without the birds there would be no crops at all, which would surely be the greater evil; and besides eating as much insect as vegetable food during the summer, which even the grain-feeders do, it is also a fact that the seeds which they chiefly eat are those of wild plants producing such superabundant crops, that they would overrun and choke other vegetation, if there were not some check to their increase. No less than 321 chickweed seeds, for instance, were found in the crop of one sparrow.

Other birds eat large quantities of burdock, plantain, groundsel, and thistle-seed; and without their help we can see, from the state of things in Australia, how rampant and unmanageable these plants, with their easily-dispersed seeds, might become.

Pigeons are the only birds which live on nothing but vegetable-food; yet the wood-pigeon is now recognised as such a valuable servant in Belgium, from its habit of eating the seeds of the poppy, spurge and others, which no domestic animal can touch, that it is strictly preserved. Where such seeds are not to be had in sufficient quantities, no doubt the pigeon makes up for it by stealing peas and corn, but the Belgians seem to have made up their minds that it is better to run the 
risk of having to pay occasional toll to the pigeons, than to have their crops choked with weeds.

In this chapter we a e necessarily considering 'nature's militia' chiefly as they affect the crops of farmer and gardener, for it is here that we are best able to see their work; and from what they do in field and orchard, we are able to form some idea of what their work is in the uncultivated fields and woods of the world.

It is only when the birds come into contact with man that any doubts as to their usefulness can possibly arise, and even here, in that part of 'the green world' which he has taken into his keeping, we are learning more and more to see that they are not only useful, but actually indispensable.

With the exception of the flying insects which carry pollen from flower to flower, there are few insects in any part of the world which are not the enemies of those who cultivate the soil, though, like prairie-fires, they have their uses where nature is sole farmer, and it would be rash indeed to say that any, even of the worst, could be entirely dispensed with. But insects in excess, which we most certainly should have if the 'militia' were withdrawn, would change the world from 'green' to brown, and cause a general famine. And the question before us is: will we share with the birds, or have all devoured by insects?

A few words as to what in temperate latitudes may be regarded, perhaps, as the farmer's three worst enemies - cockchafers, daddy-long-legs, and clickbeetles or skip-jacks. It is in the grub-state that most insects are chiefly mischievous, for this is their grand eating-time; eating is then their sole business, and they eat for their whole lives. For when they get 
their wings they usually want so little food, and that of such a kind that no one can grudge it them. A caterpillar eats leaves, for instance, and devours them greedily, whereas a butterfly takes but a sip of nectar, the loss of which is no injury to even the most delicate flower. Yet, as the winged insects lay multitudes of eggs, they cannot be called harmless, and some few of them even do a good deal of eating on their own account. Cockchafers, for example, eat leaves, and sometimes strip whole woods, while their grubs devour roots. Daddy-long-leg grubs (turnip-fly) are equally destructive, and so terribly hardy that they thoroughly deserve their name of leather-jackets. For they are very little affected by weather, and may be frozen stiff, or lie under water for a couple of days, and yet be just as lively as ever afterwards. Insects, indeed, often take a great deal of killing, and will live through frosts, especially in the chrysalis-state, when the poor birds perish by hundreds.

As for the grub of the click-beetle, its very name is enough to make a farmer shudder, for, as the wireworm, it is only too well known. For five whole years it remains a grub, eating all the time. And it will eat almost anything in the way of vegetable-food, turnips as well as sprouting corn, or hops, and grass-roots as well as any of these. Where the young corn is strong, it will sometimes recover from having its first shoot eaten off just below the ground, and will even send up two or three shoots instead of one; but when the plants are weak, as they often are on light, chalky soil, there the wire-worm destroys sometimes the half, and occasionally the whole, of a crop.

To help him in the perpetual war which has to be 
waged with these three special foes, the farmer has friends-the sparrow again, and the rook, jackdaw, magpie, jay, all the smaller birds of prey, in fact, and many of the larger; and besides these, he has the stoat, weasel, mole and hedgehog, which last, though much persecuted, is most useful, and quite inoffensive.

The battle about the rook is only less fierce than that about the sparrow, but while it is no doubt true that he does uproot some plants in his search for grubs, that he does steal a little corn, and that, when insects are scarce, or rooks too many, he even attacks the crops, still, where rooks are poisoned, wire-worm increases and crops fail. One rook will have as many as three dozen daddy-grubs or click-beetles in its crop at once, and the birds go over the ground yard by yard in the most systematic manner, working from early dawn till evening, each bird catching, it is said, at least fifty wire-worms in the day.

In some parts of the country the rooks are often joined at their work in the furrows by large flocks of gulls, titmice and others, which appear when ploughing begins, and go away when the furrows are cleared, without taking any pay from the farmer, except in the shape of the insect-food which he is glad to be rid of.

Other very useful birds, which must be passed over with a mere mention, are the various species of plover, the partridge, and the pheasant-a couple of which will eat $I, 500$ wire-worms at a meal-the thrush and the landrail, both of which clear the fields of snails and slugs, and the swallow, martin and swift, without whom the air would be so choked with flies as to be simply unbreathable.

So much, then, for the services, the incalculable 
and indispensable services, of the 'militia.' We have seen something of these, and we have seen, too, how surely punishment has followed where the birds have been exterminated; but there is a word or two to be said on the other side of the question.

It is very rash for man to interfere with nature by exterminating any one class of the labourers employed, whether in the tilling or in the protection of the fields, cultivated or uncultivated; but, at the same time, it is hardly less rash for him to interfere in the other direction, and to encourage these same labourers overmuch; or even, because they are found useful in one part of the world, to conclude hastily that they must be equally useful in another.

Thistles do not overwhelm us, and swamp other vegetation, in Europe; but he was a very rash man who imported a sack of thistle-seed into South America and scattered it broadcast about Valparaiso, with an idea of providing useful fodder for cattle! The thistle took to the soil and climate amazingly, and having nothing to check its increase, as it has at home, quickly spread over large tracts of country, to the great inconvenience of the cultivators.

Then, someone may be inclined to say, why not import birds to eat the seed? But things in nature are so exactly balanced that even this step would probably be found to have its disadvantages, and possibly the birds might turn out to be even worse than the thistles. The sparrows imported into the United States, for instance, and at first petted and made much of, have so thriven and multiplied that they are now a pest, and generally hated. But the mischief is done, and is not to be so easily undone. 
They, like the thistles, have had things their own way, for, as there were no sparrows in these parts before, naturally no special checks to their undue multiplication had been provided.

In Europe these checks have been provided; but here, again, man has too often interfered with the wise arrangements of nature, and when he has disturbed the balance and brought upon himself a plague of sparrows and other small birds, then, instead of blaming his own want of foresight, he proceeds to wage a war of extermination on these offenders, only to find himself eaten up with grubs a little later.

Of course, if sparrows and other small birds are allowed to increase until there are not grubs enough to feed them, they will naturally take whatever else they can find. But it is unfair to blame the sparrow for what is the farmer's own fault.

The natural checks provided for keeping the small birds in their proper place are the birds of prey; and these-many of the larger, and all the smaller-not only kill small birds for their own eating, but feed their young entirely upon beetles, grubs, caterpillars, flies, slugs, snails, and the various insects which attack the green things. Many of them, too, hunt by night, and so destroy the night-flying moths and beetles which escape other birds.

Yet birds of prey, especially owls and hawks, are relentlessly persecuted by farmers and keepers, because they occasionally steal a young chicken, or-more heinous offence still-young pheasants and partridges, and perhaps, yet more often, they are killed because it is the fashion to kill them.

But even owls and hawks have their avengers. 
Sparrows, multiplied to excess, take to thieving, and commit great depredations in the fields; and still worse are the plagues of mice, which mar the land.

In Scotland and the north of England there has been a great outcry of late against the swarms of mice and rats which waste the fields and rob the barns, doing far more damage than the sparrows. But why this increase in sparrows and mice? Because the owls, hawks, stoats and weasels have been killed off. Just that, and nothing else.

Owls are the very best mousers possible-better than the best cats. One pair of owls have been seen to take as many as eleven mice to their nest in the course of a single evening. Ravens, crows, hawks, magpies and jays all hunt mice, as well as cockchafers and other insects, as already said ; and the young of the brown owl are fed with anything, from snails even to kittens and puppies. But the young of the barn-owl require a steady supply of fresh mice, and she herself makes mice almost her sole diet, so that she benefits not only corn but clover. For if it is true that the crop of clover-seed depends to a great extent upon the number of cats in the neighbourhood, surely the presence or absence of those grand mousers, the owls, must make at least as much difference to it. For mice are very much addicted to eating humble-bees, as well as corn; and as the common purple clover is fertilized by humble-bees only, there can be no seed where humblebees are wanting, which they certainly would be if mice were allowed to multiply unchecked.

Whether or no people in this land, other than the naturalists, are connecting the grievous plague of 
mice in Dumfriesshire and elsewhere with the disappearance of the birds of prey, it is being clearly recognised in America that without the latter sparrows are a sad mistake. In the States, birds of prey are comparatively rare; not because they have been killed off, as with us, but because nature had not provided them-a very different matter. But now that the English sparrow has made himself unpleasantly obtrusive, hawks are being imported as the only likely means of quelling him. Why hawks instead of owls is not evident, but it will be interesting to watch the result of this second experiment; for if the hawks in their turn should increase to excess they might prove even worse than sparrows.

In some parts of the world the balance of animal life established by nature is very curious, and any interference with it is attended by danger. In some districts in India, for instance, the tiger is as useful to the farmer as owl and hawk are here. If he kills off the tigers, as his English brother kills the birds of prey, then the deer multiply and eat his crops ; and on the other hand, ' if he kills off the deer, the tigers kill him, for even a tiger must live!' so that on the whole he finds it better not to interfere.

We have already mentioned the stoat and weasel as most useful in keeping, down the numbers of rats, mice and rabbits, and the hedgehog as being a devourer of insects, with absolutely no bad habits to take from its value. Yet all these are persecuted without mercy as 'vermin,' chiefly from habit, in all probability; for the old stories as to the hedgehog's milking the cows, and rolling itself on fruit and eggs, 


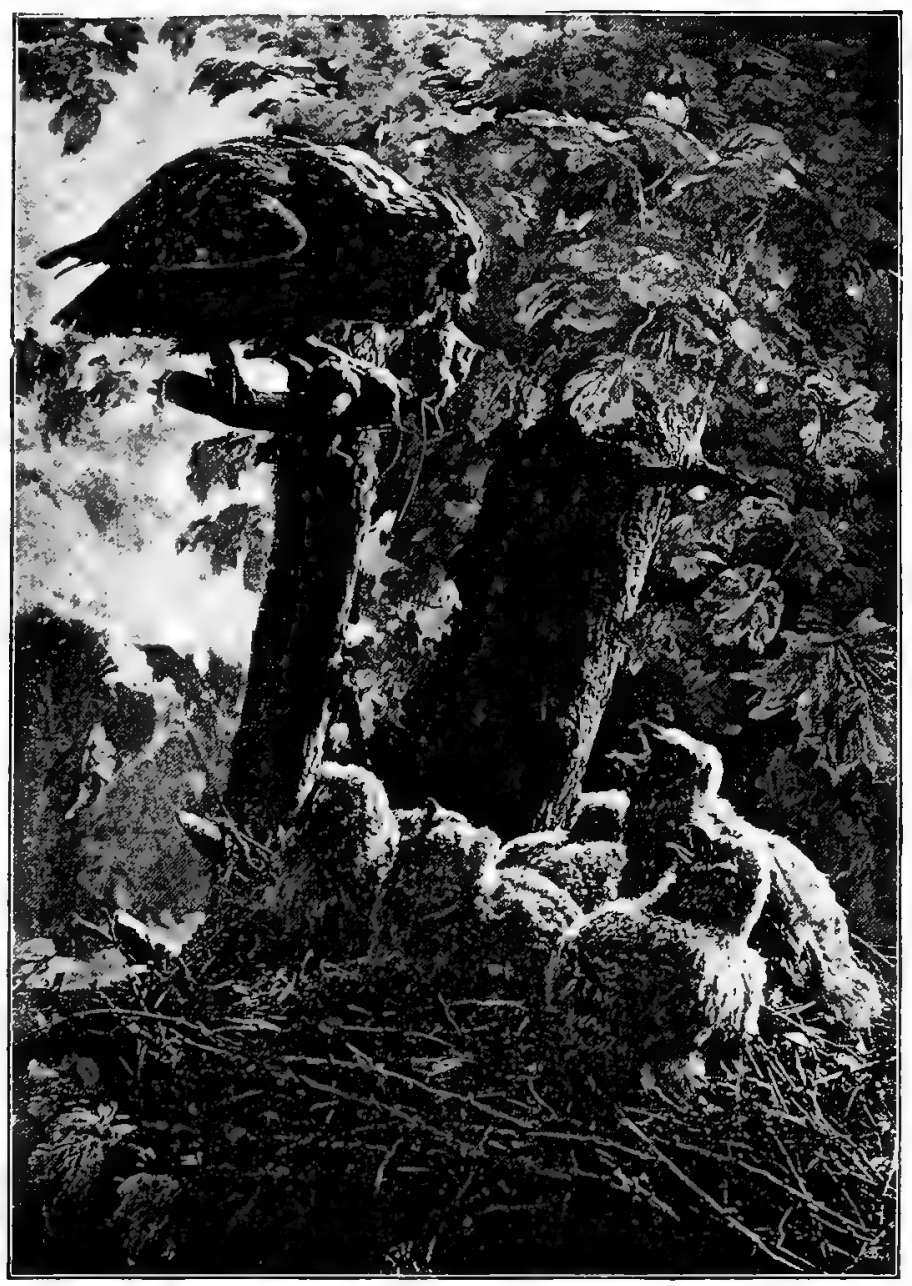



which it carries off on its prickles (!), can hardly, one would think, be seriously believed.

Another much-persecuted creature is the mole; and yet the mole is always eating wire-worm and the like, doing its very best for ungrateful man; for its appetite is voracious, and it is quite unable to survive even a short fast. The mole is not without his admirers, however, in spite of his certainly trying way of throwing up hillocks, and one of his friends says : "As surely as the farmer destroys the mole, so will he have in exchange wire-worm and turnip-fly.'

Insects are, as a whole, such enemies of vegetation that we are apt to condemn them in a body. Yet besides the many which convey pollen there are a few others which deserve honourable mention, and even the name of friends. These few are positive benefactors, for they leave the green things alone themselves and prey upon other mischievous insects.

Among these insect-friends is the lady-bird, to whom, as an American writer says, 'we should take off our hats,' for it destroys those terrible pests, thrips and green-fly.

Wasps carry off flies and caterpillars to feed their young grubs; and some species of ichneumon-fly deposit their eggs in the chrysalids of moths and butterflies, as well as in grubs and caterpillars; thereby killing them. But of all insects, perhaps some of the beetles are the most useful, for, both in the grub and in the winged state, they catch and devour living prey.

To sum up: without insects many plants would be unable to produce seed, and so must in time die out; without the small birds, insects would increase so 
much that all green things would be destroyed; and without the birds of prey to keep the number of small birds within bounds, not only would farming be quite impossible, but wild plants would also suffer; for, wher the insects were devoured, or even very greatly redinced in numbers, the plants dependent upon them for help would be seedless, and the remainder would be so plundered of their seed by flocks of hungry birds, that little would be left for sowing.

Both insects and birds, then, are the enemies of vegetation when their numbers are multiplied to 'excess; but without them, there would be no vegetation at all. 


\section{XXII.}

MAN'S WORI ON THE FARM.

Hitherto we have been considering how the world's fields are cultivated when the work is left entirely to those who labour without hands-to air, wind, frost, rain, snow, sun, glacier, river, earthquake, volcano; to the worms and others which plough the soil; to the insects which act the part of pollen-carriers between the flowers, and to the birds which keep the insects in order, and help the winds and waves to scatter the seed. These and many other workers not here enumerated, are at work constantly in the fields which man has taken under his own care, as well as in those still left entirely to nature. Together they keep the world green, and they would keep it green if there were not a man in it; for they are quite able to do without his help in the matter, though he would be entirely helpless without theirs.

But man has done much to modify the result of their combined labours, not only in that small proportion of the earth which he cultivates or occupies, but even beyond. Where men dwell together in numbers, there the earth is necessarily less green, for towns, cities, roads, railways, have invaded the woods and fields, and 
have not only turned out their inhabitants, animal and vegetable, but have made their influence felt over a much wider space than that which they actually cover. Even where wild plants have been turned out only to make way for cultivated ones, the result has been similar in some degree. The earth bears better crops, no doubt, at least from man's point of view, but they are less crowded, and the fields are bare for some part of the year.

But besides cutting down woods and forests and clearing away bush, man has drained fields, as well as marshes, he has cut canals, and he has taken plants from one land to another and from one hemisphere to another, in many cases intentionally, but in many others quitè unintentionally.

Other changes, though man has been the cause of them, have taken place altogether without design on his part; and even where he has intended to make some change, he has not seldom found that he has done a good deal more than he meant, and has in fact started a whole series of changes.

Trees, for instance, are cut down for the sake of the timber they will furnish, and nothing else, perhaps. But a great deal more is done than merely to take away so many loads of wood. To begin with, the soil is exposed and dried, and the plants which have flourished in the shade and moisture will die off. The insects which fed upon the plants will die off too, and the birds which fed on the insects and found shelter in the trees will be driven away.

If the trees are simply cut down, and the ground is left unoccupied, it will be gradually taken possession of by other plants or trees. In Germany, where the 
ground has been cleared of wood and then left to itself, it is covered in a few years, first with shrubs, then with trees, chiefly of the pine tribe. In eight years, it. will become a coppice with saplings five or six feet high; and all this without any further interference on the part of man.

Man makes the vacancy, and nature, if only let alone, fills it again. There are parts of the United States where pine-woods have been cut down for railway purposes, and have been at once followed by oaks, planted by some or other of nature's many labourers. Why pines should not have sprung up again, when their seeds must, one would imagine, have been present in the soil, seems to be one of the many questions still waiting to be answered; but it is a well-known fact that in many places where forests are cut down, trees of an entirely different kind do spring up in their place. And of course different trees mean different insects, and different birds.

Mr. Darwin mentions some remarkable changes of this sort brought about simply by the enclosure and planting with Scotch fir of a very barren heath in Staffordshire never before touched by man. In fiveand-twenty years, the vegetation of the planted and unplanted portions had become so different that the soil might have been supposed to be of quite distinct kinds. Within the plantation there were fewer heathplants, but there were also twelve species of other plants, not counting grasses and sedges, which were not to be found on the heath at all. Six species of insect-eating birds, too, were common in the plantation, but did not stray outside it; while two or three 
others, quite distinct from these, were to be found only on the heath. For change in the vegetation had been followed by a corresponding change both in the insectlife and in the bird-life.

Not a marsh nor a field can be drained, not a canal can be cut, not a railway or even a road can be made, nor a house built, without making some change, and in some cases a very great change, in the vegetation of the place or immediate neighbourhood. As for the growth of towns and cities, that affects far more than the immediate neighbourhood; for not only is many a field covered with bricks and mortar, but the smoke from the chimneys and the increased traffic on the roads have their effect upon vegetation, sometimes for miles round.

When to houses are added factories, the evil influence is felt still more widely, and that even by lichens. Lichens are such very passive-looking vegetables, so little life-like, and so largely composed of mineral matter, that one is apt to fancy they cannot be sensitive. And they are in many respects very hardy, as we have seen. But they, too, have their limits of endurance. They may stand both biting cold and parching heat; but smoke kills them, especially the larger leafy-looking species, such as grow on the trunks of trees. They flourished formerly in the woods, seven miles from Newcastle, and might flourish there still, but for the change in the atmosphere, for nothing else is altered. But the factories and collieries, though several miles off, have polluted the air; the trunks and branches of the trees have acquired the grimy look which they wear in cities, and all the larger lichens, and most of the smaller, have been killed by 
the soot. Lichens have also disappeared from Kew Gardens, and are rare in Epping Forest.

Changes of this sort are, however, very small compared with those which have followed the destruction of primeval forests, the introduction of agriculture, the wanderings, and even wars, of the human race, the voyages of traders, and the discovery of new lands.

Those who are accustomed to cultivate the soil, in however rude and primitive a fashion, naturally carry with them on their wanderings the seeds of such plants as they have found useful. This is true even of such nomads as the gipsies, whose attempts at agriculture have been necessarily of a very limited description, since their crops had to be sown and reaped during - the short time that they remained stationary.

But besides carrying some seeds purposely, travellers of all sorts, whether nomads or not, frequently carry others by pure accident, and quite unconsciously. They mean to take with them only cultivated plants, but somehow or other, in this way and in that, the weeds contrive to get taken too. It is often quite impossible to say. how they have been brought, but there they are. This is especially the case with what may be called cultivated weeds-those which are found in cultivated fields and nowhere else; for, unless great care is taken, their seeds are very apt to be mixed with those of the crop, and then both are sown together. Clover and grass seeds are especially liable to adulteration of this sort; broom-rape and dodder are conveyed in the one, and worthless grasses, and many another weed, sneak in with the others.

Many seeds are conveyed, also, in forage; and in 
1870 , during the Franco-Prussian war, seeds were thus brought to France by troops from Algiers, and were scattered in different places, where they germinated and grew up, but apparently found soil or climate uncongenial, and died out in the course of two or three years. Had they travelled south instead of north, they might have become permanent colonists.

Again, the ballast of vessels is a very favourite hiding-place for seeds; and foreign plants often first spring up in the neighbourhood of sea-ports, being brought not only in this way but in others less obvious. Intercourse of any kind with foreign lands is almost sure to lead to the introduction of foreign plants, not only without any effort on man's part, but often quite against his wishes.

Fleeces from South America, Mexico, and the Cape, have been the means of bringing seeds to some of the valleys of Gloucestershire, and to the Pont Juvenal, near Montpellier, where they were washed and spread out to dry; and in many cases these seeds have not only germinated but blossomed, though they have not lasted more than a season or two.

No one, probably, would wish to assist that troublesome weed, the wayside plantain, to migrate, yet, if the tradition of the American Indians is to be trusted, it has followed the white man all over the western continent. The seeds are very minute, though they are not otherwise specially capable of dispersing themselves; and if once they managed to slip in anywhere, they would be carried unnoticed. Certain it is that the Indians look upon this plantain as having come with the white man; for they call it the 'White Man's Foot.' Botanists have been rather sceptical on the 
subject,- as there is a plantain acknowledged by all to be a native of America, which is so like the stranger as to have been confounded with it for some time, except by the Indians and the cows. The latter will eat the native plant, but not the other; and as the two are now distinguished by botanists, it seems likely that the Indians are after all right in their tradition.

One weed, the Canadian fleabane, made its way to Europe by very singular means. A single seed came over accidentally in a stuffed bird. This was purposely sown, no doubt out of curiosity, and then the deed was done, and the result was beyond control. For the fleabane has downy seeds, "and these flew away and spread themselves all over Europe without any further assistance.

Few weeds have come, or are ever likely to come, from China, by all accounts, for the population is so dense, and labour so abundant and so careful, that none of the cultivated districts are good huntinggrounds for the botanist. When one thinks of the many plants to be found in our fields and meadows, besides those sown and cultivated by the farmer, it is strange to learn that, with the exception of some few water-plants in the rice-fields, the botanist finds scarcely any plants in the fields of China but such as are cultivated. That is to say, he may find stray plants of millet among the beans, or lentils among the corn, and so on; but of 'weeds' pure and simple, uncultivated plants, he finds scarcely a specimen, and anything answering to the gay poppies and rampant bindweed of our corn-fields is absolutely unknown!

It is a curious fact that almost all the really troublesome weeds in the world are emigrants from Europe. 
But before we consider, in their proper order, a few of the more important changes which have taken place in the vegetation of different lands, a word or two must be said about names.

It is necessary to be cautious about accepting popular names, for these are often given without much reason.

The Indian fig, or prickly pear, is neither fig nor pear, but an American cactus. The Jerusalem artichoke is an American sunflower, in Italian Girasole (Turnesol), which was corrupted into 'Jerusalem,' and it was called an 'artichoke' because the tubers somewhat resembled in taste the heads of the real artichoke.

As for the names 'apple' and 'pear,' they have been used in the most reckless manner both in ancient and modern times. The Persian 'apple' of the Greeks and Romans was the Chinese peach, and their Punic 'apple' was the Persian pomegranate. The 'golden apple' of the Italian is not, as one might suppose, a pippin, 'but the tomato. The 'alligator pear' of Mexico is not a pear, nor has it any connection with alligators. Its native name is ahuaca, corrupted by the French into avocat and avocatier, suggestive of some equally mysterious connection with lawyers, with whom, however, it has as little to do as the pomme d'acajou has with mahogany. As to the red and white 'currants' of our gardens, what right had they to steal the names of the small grapes of Corinth, which we now call grocer's currants for distinction?

The potato is too curious an instance of this kind of thing to be passed over. By French and Germans it has been called the 'earth-apple,' and by the Hungarians the 'earth-pear'; but the English name; 
cannot be said to be much more felicitous than these. For the potato, like its cousins the tomato and the tobacco, is a nightshade; and the batata, after which it is named, is a convolvulus, a native of Brazil. The Brazilian batata bears tubers, which were imported into England from Spain in considerable quantities before the 'potato' was known, or at least before it came into general use; but the two are much alike in appearance, and the later comer was so much the more popular, that the name of the convolvulus was transferred to it, and the true batatas came to be known as 'sweet potatoes.' To make the confusion still worse, the potato has been introduced into Brazil, where it was formerly unknown, and is there called the 'English batata.'

As we have no means of telling when the first migrations of man took place, it is quite vain for us to guess at the date of the earliest migrations of such plants as he carried with him. The earliest wanderings of both are equally involved in obscurity, but we know that they began long before history has anything to say about them; and we know, too, that cultivated plants had been brought from Asia to Europe even in these far-off, dateless ages.

The lake-dwellers of Switzerland, who built their habitations on piles, and used none but stone implements, knew something of agriculture; and, from the blackened remains of grain found, we know that they cultivated three kinds of wheat, two of barley, and two of millet, which are none of them natives of Europe, and must have been brought at some time or other from Asia. 


\section{Man's Work on the Farm}

But if we cannot say when the first corn was brought to Europe, still less can we say when, and by whom, the various kinds were first cultivated. It was, however, at such a very remote period, that they are none of them found in the wild state.

The earliest changes in the vegetation of Europe, of which we have any historical notice, are those made in the south of Italy by the Greek colonists (from B.C. 734), who brought with them the garden-rose and the lily. On their arrival, they found the country much overgrown with wood, among which beech-trees were especially prominent, but there were none of the plants and shrubs then growing there which we are accustomed to think of as particularly belonging to Italy.

We can hardly imagine Italy without the myrtle, laurel and olive, to say nothing of the orange and palm. But oranges were quite unknown both to Greeks and Romans, and Italy was without myrtles and laurels until they were introduced by the colonists and planted round the temples of Aphrodite and Phœbus, to whom these shrubs were sacred. The olive was in like manner sacred to Pallas, and was therefore pretty sure to accompany the wanderers, for it is one of the trees which has been cultivated from time immemorial, especially in Syria, from which the cultivated olive seems to have come originally. Once introduced, it would soon spread, for birds are very fond of the berries, and scatter the seeds far and wide. A wild variety, from the Punjab and Beloochistan, has been conveyed by their means to Portugal, Madeira, Morocco and the Canary Islands.

But near Messa, in Morocco, there is a grove of olives planted in such a regular, but whimsical fashion, 


\section{Man's Wark on the Farm}

that one cannot suppose it to have sprung from the seeds scattered by birds; and if tradition is to be believed, the trees grew from the pegs used in picketing the horses of an army proceeding to the Soudan. Owing perhaps to some sudden alarm, the camp was hastily broken up, and the pegs, cut from olive-trees in the neighbourhood, were left behind and took root.

No trees but evergreens-the olive, cypress, and oleander-are depicted upon the walls of Pompeii; from which it seems that the beeches, and other trees, had been either exterminated or driven into the mountains, or at least had ceased to be in any way conspicuous, by the time these works of art were executed.

What plants may have been introduced purposely, or accidentally, by the Phœnicians, who had trading stations all about the Mediterranean, in Europe as well as in Africa, we have no record to tell us; but, judging by what we have seen in other instances, it is impossible to suppose but that some plants followed, or were conveyed by them to the various coasts they visited. And their voyages extended westwards as far as Britain, and south as far as Senegal.

Nor do we know much more of the effects produced by the wars of Greece and Persia, or the expeditions of Alexander the Great, which took him as far as India. Rice was certainly made known to the Greeks by the conquests of the latter; but no attempt seems to have been made at cultivating it.

It is in the second century (B.C.) that the Chinese first came into contact with Western Asia, on the occasion of their helping the Scythians to ravage the shores of the Caspian Sea. A little later, their ambassador, Chang-Kien, followed on a peaceful mis- 
sion; and coming as he did from a nation of agriculturists, he seized the opportunity to carry back with him to China various useful plants, such as the bean, pea, cucumber, water-melon, lucerne, saffron, sesame, spinach, nut, and others, hitherto unknown in the East. This is the earliest instance recorded of the migration of cultivated plants eastwards. Westwards we know they had travelled long before.

Whether the ambassador was so thoughtful as to bring any plants with him, or whether any came accidentally in his train, we do not know; but the peachtree is said to be a native of China, where it has been cultivated for ages; and it was so well established in Persia, when the country was invaded by the Romans, that they introduced it to Europe as the 'Persian apple.' The Romans, too, about B.C. 68, brought from Pontus or Armenia the first cultivated cherrytree; and it is said that a tree laden with fruit figured in the triumph of the victorious consul. Cherries became at once so popular that, as Pliny says, ' in less than a hundred and twenty years after, other lands had cherries, even as far as Britain beyond the ocean.'

As to any other plants which the Romans may have brought to Britain, we have no certain knowledge; no doubt they cultivated here all such plants as they found useful at home, so far as the climate would allow them; but they have at least the credit of having brought and left with us two wild plants, the columbine and the Roman nettle. The nettle is one of several plants which are, it is said, sure to follow the steps of the European wherever he goes; the plantain, goosefoot, and fennel are others.

But, according to the old botanists, the seed of the 
large Roman' nettle was purposely brought by the Roman soldiers, 'who sowed it for their use, to rub and chafe their limbs, being told before they came from home that the climate of Britain was so cold that it was not to be endured without some friction to warm their blood.'

However this may be, the Roman nettle, which is a larger species, and endowed with more venomous 'stings' than the common stinging-nettle, is rare in England. But it formerly abounded in the streets of Romney, and, though driven out of the town, still flourishes in the neighbourhood. Now, it was near Romney that Julius Cæsar landed, though the town does not take its name from the Romans, but from a Saxon word signifying ' marsh.'

It was not until Roman times that the date-palm -was brought to Italy; and then, as it did not bear fruit, it could neither run wild nor make itself thoroughly at home, and was therefore dependent upon the care of man. But the northern barbarians, who overran the empire in later times, cared nothing for a tree which was only beautiful, and therefore allowed it to die out, and Italy was without palms again, until the Saracens brought them back.

The coming of the Arabs, or Saracens, made a vast change in the vegetation of the lands of the Mediterranean; for, destructive as they were in some respects, they had the Eastern respect for, and love of, trees; and though their power did not extend nearly as far to the east as did that of the Romans, it was they, and not the Romans, who brought to the Mediterranean the many Asiatic plants which we are now inclined to think must always have been there. 
The Romans, though they had colonies all round the shores of the inland sea, made no such changes in its vegetation as those which followed the coming of the Saracens. It is, indeed, curious to reflect how much Europe owes in the way of beautiful trees and flowers, and of useful plants, not only to the fanatical, blood-thirsty Arab, but also to the 'unspeakable' Turk, who brought us the horse-chestnut, tulip, and other ornamental plants. The Arab of to-day carries with him the seeds of his favourite plants, fruits and vegetables, even when he is on his slave-making expeditions in the heart of Africa. And wherever he settles, if it be but for a year or two, there he makes a garden.

It was so, also, in the eighth and following centuries. Egypt, North Africa, Spain, the Balearic Islands, South France, Sardinia, South Italy, Sicily, the Levant -all felt his influence, for wherever he went he tried to make the new country as home-like as possible.

The planting of the first date-palm in Spain was an important ceremony, performed by the first caliph, Abdurrahman himself, in a garden near Cordova, his capital; and this tree is said to have been the ancestor of all the palms of modern Spain, including the forest of 60,000 fruit-bearing trees in Valencia.

In Calabria and Sicily the palm was allowed almost to die out again when the Saracens were gone, and for the same reason as before-because it did not bear fruit; and it was not until the ceremony of the blessing of palms on Palm Sunday was introduced, that people began to think it worth cultivating for the sake of its foliage only.

Then, however, the palm began to be made much 
of in Italy, as there was a brisk demand for its 'leaves'; and the great grove, which is miles long, was planted at Bordighera, simply for the supply of these.

Among the other plants which the Saracens brought to Europe, were the orange and lemon, the sugar-cane, rice, cotton, saffron, and the locust-tree. The citronfamily, which includes the lime, orange, and lemon, seems to be a native of China, where the fruits grow wild, and many varieties have been in cultivation for ages past; but how and when they travelled westwards, as they must have done before the Arabs could make their acquaintance, we have no means of discovering.

Wherever the Arab went, there fields of saffron were sure to spring up; for this was a flower he loved and valued very highly for its perfume, flavour, dye, and medicinal properties. Greeks and Romans had known it as the crocus, and prized it too, but the extreme fondness of the Arabs for it caused it to be cultivated far more extensively than it had ever been before; and their name for it, 'saffron,' quite took the place of the classical one.

Rice had long been known as an expensive foreign article; but there had been no attempt at cultivating it out of Asia, until the Arabs tried it with much success in the Delta of the Nile, and soon after carried it further west. It flourished in the marshes of Valencia, and elsewhere in Spain; but the Italians were only too successful with it; for finding that it could be grown without difficulty, they turned their fields and meadows into swamps, in such a reckless manner that much illness followed, and the law stepped in and set strict limits to its cultivation, 
Large crops are, however, still grown in the plains of Lombardy.

So much was done by the Arabs to make the vegetation of the East known in Europe, that the Crusaders found little to bring home in the way of useful plants; and the next important addition to the food-plants of Europe, though that too came from Asia, was a much more northerly one.

Buckwheat grows wild about the river Amoor, and in some other parts of Asia, and as it made its first appearance in Europe at the same time as the gipsies, early in the fifteenth century, they have generally had the credit of introducing it, as its many names, such as ' heathen' and 'Saracen' corn, sufficiently testify, for these were applied indiscriminately to the gipsies also. It seems not improbable that they should have carried it with them, for it grows on poor soil, and takes but a short time to come to perfection, and would therefore be well suited to the needs of those who lead a wandering life.

Another plant which is said also to have followed the gipsies from Asia all across Europe is the deadly thorn-apple, which is unpleasantly suggestive of some of their evil practices.

Hitherto the various migrations of plants, of which we have any certain knowledge, had been, with few exceptions, from east to west. And now, with the wonderful discovery of the New World, fresh fields were opened out to them, still in the same direction. Europe was, as it were, but a stepping-stone for many, on their way to the Far West; and in the case of not a few, it was only when they reached the western hemisphere that they showed what they were capable of. 
and became important crops. Rice, cotton and sugar, for instance, were all grown in the south of Europe to some extent, after the Saracens had introduced them there, but what were the little plantations of Spain and Italy compared with those of the West Indies and America?

However, though the stream continued to flow westward, and that with such vigour that nearly the whole of the vegetable world of Europe seemed to be on the move, no sooner was the New World discovered than a counter movement set in. The eastern world certainly gave more than it received; but it also received much, and American plants are now so well known throughout Europe and great part of Asia, that they are hardly any longer looked upon as foreigners; and it is quite difficult to realize what the lands of the Mediterranean, and even our own kitchen-gardens, looked like before the discovery of America, when the blue-green, sword-leaved agave, commonly called the American aloe, the magnolia and prickly pear, were unknown in the south of Europe; when Italy-had no maize, macaroni, or tomatoes, the Irish no potatoes, and the Turk no tobacco.

When we think of the way in which the prickly pear has spread over all the coasts of the Mediterranean, north and south, and of the broad fields now devoted to the cultivation of maize and potatoes, to say nothing of the garden-ground occupied by Jerusalem artichokes, scarlet-runners, haricot-beans, and ornamental plants, we may form some idea of the alterations produced in the green world of the east by the discovery of the other half of the globe. There is indeed hardly a park, or even a cottage-garden in Europe, where plants from 
the west are not now familiar objects; they are plentiful in China and Japan, and throughout the length and breadth of India. But still, though they have considerably altered the appearance of our gardens, and, in some districts, of our fields, the change has been mainly confined to these, the cultivated portions of the soil. In the north, at all events, American plants have not run wild in any overwhelming manner, though the prickly pear has done so in the south, and the pineapple has covered some parts of Borneo; and it is true that the American pond-weed even put us to considerable expense, by choking our canals. The general appearance of our woods, moors, wild hill-sides and 'wastes,' at all events, is little, if at all, altered by the presence of strangers; and though potatoes are an important crop in the north, while maize and tobacco occupy a good share of the cultivated ground in the south, yet, except in some few districts, it is only a share, and wheat, barley, rye, oats, clover, etc., form the chief part of the crops of Europe now, as they did before Columbus crossed the Atlantic.

It is far otherwise, however, with that new world which he discovered. In many parts, European plants have almost ousted the natives, and have entirely altered the character of the vegetation. In the south, for instance, I80 miles of wild artichokes and clover have sprung up since first the continent was visited by Europeans. Growing entirely on their own account, without any other help from man than that of an 'assisted passage,' they have overpowered whatever native plants occupied the ground before them, and are now being themselves invaded here and there by large groves of wild apple-trees, also European, planted 
by pigs and cattle. But in the north, greater changes than this have taken place; for miles-hundreds, thousands of square miles-have been brought under cultivation which were never cultivated before; and the whole of the crops grown throughout the United States are foreign, with the trifling exception of Jerusalem artichokes and pumpkins!

When Louisiana was settled by the French, for example, less than a couple of hundred years ago, the uplands were covered with magnificent forests of elm, ash, oak, cherry, magnolia, mulberry, and wild grape. Whereas the greater part now, where it has not been abandoned as exhausted, is covered with cottoncotton not of the native species, but that brought to Europe by the Arabs.

This is only a sample of what has occurred throughout the United States and in Canada. For it is a curious fact that, useful as are many of the plants which America has given to Europe, they amount to no more than forty-five species-about 250 species are in common cultivation all over the globe-and of these, all but the two already mentioned are natives of South or Central America, for the Indians of North America were chiefly hunters, not agriculturists.

Potatoes, it is true, were brought to Europe from Virginia, but they were strangers for all that, and not known in the State until introduced by Europeans, who had made their acquaintance in the south; and to make room for them, as well as for the various kinds of corn, grasses, clover, cotton, hemp, flax, fruit and vegetables, which form the main part of the crops of the United States farmer, native plants have necessarily been turned out. They have not been exterminated, 


\section{Man's Work on the Farm}

but the space they occupy has been much circumscribed, and will be limited more and more, as more land comes into cultivation.

Coffee from Abyssinia, the sugar-cane, peach, and orange from Asia, are all extensively cultivated in the Western world, while the two last have run wild, and form considerable groves in some parts; and whole forests of coco-palms waved on the islands near Panama within a hundred years of their first introduction. All these were valuable additions to the vegetable wealth of the new world; but the more foreigners, the fewer natives. The green things were quite as many, but they were different.

So much, then, for the useful plants. It has been said that 'no beautiful or useful organic species, animal or vegetable, becomes naturalized in any country without the intervention of man, while the noisome and ugly succeed in establishing themselves in spite of him '-a sweeping assertion, which, as regards the former half of it, is hardly borne out by facts. But the second half is undoubtedly true enough.

Though we cannot consent to call 'noisome and ugly' the weeds which beautify the fields and meadows of Europe, we must admit that they have followed man quite without his invitation, though not without his unconscious help, and that in many cases he has to fight a sore battle with them, and does not always come off conqueror.

Most of our weeds have made their way to the West by the various ways already mentioned, and among them, it must be confessed, some which are not only not ornamental, but most injurious to the 
fields. So extremely troublesome are some of these, of the thistle tribe, that laws are passed to ensure their being cut down, and fines are inflicted, in some parts, of a dollar per plant if they are allowed to ripen their seed; while so desperate is the battle felt to be, that, in Manitoba, persons who do not cut them down within five days, after they have been warned, are fined $\ell^{I}$ a day. Station-masters are held responsible for the weeds on railway property; and seed-merchants convicted of selling seed containing any admixture of wild oats, wild mustard, or 'Canada-thistle,' are fined from $£_{2}$ to $£_{20}$. Nevertheless, in spite of the war waged against it, the last of these is a 'pest' on all badly cultivated farms, and renders some of the country roads of Ontario almost impassable.

But now to consider briefly some of the vegetable changes which have taken place in other parts of the globe. The last of these have been due to the discovery of Australasia, where all the crops now cultivated, as well as many which are not cultivated, are foreign importations from Europe, Asia, and America, for Africa has supplied few emigrants.

None of the plants grown by the natives had oeen sufficiently improved to make them worth cultivating by Europeans ; and the only useful plant which Australia has given to the rest of the world is the eucalyptus, which seems already to belong to the Mediterranean as much as the olive, cactus and aloe.

In Australia, as elsewhere, man has had to find out by experience how hazardous it is to bring colonists into a new and comparatively unoccupied land, unless he is sure he can control them. It is not only in the matter of rabbits that he has discovered his mistake. 
$\mathrm{He}$ had, to be sure, no conscious share in bringing the Pampas-artichoke to Australia; for the seeds made use of his cattle and his ships without consulting him; but he negligently allowed the plant to establish itself. He did not eat its heads, or boil its stems, as he might have done; and it has improved the opportunity to form an impenetrable belt along the margins of the creeks in many parts of Victoria and New South Wales. But in other cases man has directly brought his troubles upon himself, though it would be hard to blame him; for who, seeing the sweetbriar for instance at home, could possibly guess that it would prove a nuisance abroad? Yet this is just what it has done. It has grown so rampantly as to make whole regions in Tasmania practically valueless, for the expense and difficulty of clearing it away are so great that the land has been abandoned and given over to the enemy.

The prickly pear has also proved an expensive emigrant, for it has escaped from the gardens in which it was to have been confined, and has taken possession of extensive districts, from which it will not easily be dislodged. This cactus, as well as the Scottish thistle -brought over by a patriotic but misguided Scot, who has not received the thanks of the community-has been the subject of special Acts of Parliament, and to keep the two even in check costs the country many thousands every year.

These and the Capeweed, which has nearly destroyed every natural pasture plant for miles round Melbourne, having sprung from seed thrown out on some waste land-these are, perhaps, the worst vegetable enemies of the Australian. But they do not by any means 
exhaust the list; and even the watercress, which is humble enough at home, has become so wildly luxuriant in some parts as actually to dry up sluggish streams and cause much inconvenience to the sheep.

Some of the accidental colonists, on the other hand, have turned out real blessings-such, for instance, as a coarse species of grass which somehow found its way to Australia from India, as is supposed. In Arabia, as well as in India, this grass supplies food for cattle in districts which would otherwise be desert and uninhabitable; and it is of incalculable service in the warmer parts of Australia, flourishing where other fodder-plants cannot stand the heat, and keeping luxuriantly green the district round Sydney, which before its coming had been withered and desert-like throughout the summer and autumn.

Such, then, are some of the more striking changes which man has made, intentionally and unintentiorally, in the appearance of the green world. They began as soon as he began to cultivate the soil and interfere with the natural labourers, and they have been going on ever since more and more rapidly, especially during the last three hundred years. And what we see now taking place in America and Australia may serve to remind us of what has been done in Europe; for here, too, the space now occupied by fields, orchards, gardens, as well as by towns and villages, was covered in bygone times by a dense growth of forest and underwood and green things, of nature's planting.

And so, also, with the crops. If those grown in Australia are all foreigners, so, too, are most of those grown in Europe; for, though in many cases we have 
almost forgotten the fact, it is to Asia that the world is indebted for the most important of its food-plants.

But with all that man has done, and widely as his influence is felt beyond his own especial domains, he has at present taken but a small portion of the soil actually under his own care; and even in that small portion he would, as we have seen, be quite helplessunable to produce even so much as a single cropwithout the constant help of the many natural labourers who are always at work, some or other of them, day and night, summer and winter, in every part of the ' great world's farm.' 


\section{N D E X.}

ABYSSINIA, 4I, 356

Acacia, $6,98,306$

Acids, 35,136

Africa, $1,6,98$

', South, 66, Iro, 112, 115

Air, 19, 164, 176

" moisture in, 19, 125

Agave, 353

Albumin, 158

Aloe, American, 193, 353

America, plants from, $353-4$; taken to, 354-7

Ant-eaters, 88

Ants, 82-87, 24I, 306-9

Apple, 219-20

"' wild, 276, 354

Arabs, 349-50

Arbor-day, I2r

Artichoke, Jerusalem, 344, 355; wild, $3,146,297,35^{8}$

Ash in plants, 16, 140-4, 145

Asia, plants from, 345.52

Australia, 97, 266, 357

BALANCE OF LIFE, 334-6

Bananas, I62

Bark, 9I

Basalt, 20

Beans, I3, 280

Beavers, 45

Bees, 215-22, 227, 230

," colours preferred by, 225

" flowers shunned by, 224

", humble, 13, 218, 225, 227, 232

, protection against, 244

Beetles, 70, 236, 3 I0, 329, 335

Bindweed. 52, 233

Birds, 3I3
Birds, destruction of, 314, 316-17

" as seed-carriers, 26r-73

,fertilization by, 224, 234

Bison hollows, $5^{8}$

Black cap, 320

Black earth, 6r, 62, r34, 14 6

Blossom, size of, I93.4

Blossoming, 193

Bourbon, Isle of, 323

Brazil-nuts, 265, 290

Breathing, I74

Buckwheat, $35^{2}$

Bulbous plants, I73, I92

Burrowing animals, 63

Burs, 265-7

Butterflies, 229, 3II

CabBage, 96, 103, 159, 279

Cactus, 35, 36, 98-9, I II, 353, $35^{8}$

Canadian fleabane, 343

Carbon, I60, 162, I67, 173-5

" dioxide, 22, I6r, I64

Carnivorous plants, I49

Carses, 44

Catkins, 209

Caterpillars, 310-IX, 320, 321

Cattle, influence of, 276, 292, 294

Cedar, red, 272

Cells, 167-9

Ceylon, sand-bars of, 53 , cinnamon in, $27 x$

1, vine in, 187

Cherry, 348

China, agriculture in, 347

" plants from, 348,351

.. weeds ín, 343

Chinese gardeners, 176 
Cinnamon, 271

Citron, 35r

Clover, I42, 146, 218, 333, 341, 354-5 roots, 56

Coco-nut, 54, 257, 356

Cockchafer, $325,328-9$

Colchicum, I92, 206

Colonists, $285,296.7$

Colours, meaning of, 224-5, 228, 274

Composites, I96, 299

Convolvulus, 53, 233, 345

Coral-sand, 53

Cork, 9 I

Corn, 345

Cotton, 353

Crabs, 69

Cranesbill, 289

Cross-fertilization, 204, 206

Crowding, 250

Crown-imperial, 224

Cuckoo, 316

Cultivation, effects of, $33^{8}$

$$
\text { " extent of, } 3
$$

Currant, 213, 344

Currents, 256-9

Daddy Longlegs, 328

Dahlia, I97, 224

Dartmoor, $3^{8}$

Date-palm, 210, 350

Decay, I54

Defences, 240

Delta, 43

Desert, Kalahari, II0, II2 I4, I25, 128

"Nubia, I2I, 187

"Sahara, 6, 118

Deserts, 2, 5, 6

,. vegetation of, 112,122

Djebel Attakah, 5

Dolomite Mountains, 5

Double flowers, 197

Down, 255

Downs, 39

Drought, causes of, II8-121, 323

Dust, 47

$$
\begin{array}{ll}
" & \text { meteoric, } 7 \\
" \text { on leaves, I76 } & \text { sirocco, } 47 \\
" \text { volcanic, } 48
\end{array}
$$

EGYPT, 4I, I20-2I

Enclosure, effect of, 27r, 294, 339

Eucalyptus, 97, I12, 357

European plants, 285, 298, 354

Evaporation, 91

Evergreens, 95, 186
FALLOW FIELDS, 156

Farm, mearing of word, 4

Ferments, I54

Fertilization by bees, 2r5-22

Fig, 247

by birds, 224, 234

by butterflies 225,228

by fies, 236

in bud, 205

by moths, $231 \cdot 2$

self, 204-206

by snails, 239

by wasps, 235

by water, 2I4

by wind, 208-19

Fires, forest, $x 43,293$

, prairie, 6I

Fire-weed, 293

Foliage, 98, ro3

$$
\text { desert, } 97
$$

Food of plants, I5, I39, 157

Forms, different, 222 values of,

Foxglove, 7 22I, 245

Frost, 25, 156, 293

Fruit, 190, 212

, -eaters, 273

"ipening of, $179-181,185$

Fuchsia, I95, I98

Fungi, 172

GASES, I8, I64

,' weight of, 164

Germs, 154

Gipsies, 341, $35^{2}$

Glaciers, 27

Glass road 26

Goats, 7, II9

Goose-wheat, 260

Gourds, I I I

Granites, 2337

Grasses, 4, 102, 142, 209, 301

Grasshoppers, 3I9, 323

Growth, rate of, I72, I93

Grubs, 3Io, 3I4-I5. 3I9-20

', lawsuits aguinst, $3^{\text {II }}$

Gulf Stream, r84, 259

Gum-tree, 97

HAIRs, IOO, 305

Hawks, 270, 334

Hawthorn, 272

Heather, 142

Hedges, 47, 57, 3I5

Helena, St. , II9

Holly, 217, 297 
Horse-chestnut, $35^{\circ}$

Humming-birds, 234

Hungary, dust-storms, 50

" floods in, 46
saltworts in, I44
sparrows banished from,
326

ICE-PLANT, IIO

Insects, numbers of, $9,3^{18}, 3^{19-22}$

Iodine, 140

Iron, 20, 169

Italy, birds destroyed in, 316 " plants introduced into, 346

JAMAICA, 267, 27x, 323

KaLAhari Desert, II2, II4, 128

Krakatoa, eruption of, $4^{8}$

LAKE-DWELLERS, 345

Landes, 57

Larks, 3I7

Lava, breaking up of, 3 I

"lichens on, 3 I

Leaf-green, 169, 172

, pores 93-5, I 7 I

Leaves, altered, 157,196

, number of, 103

, office of, I69

, size of, $\mathrm{IO}_{3}$

Lichens, 4, 6, 30, 340-4r

Locusts, 275, $3^{\text {IO-II, }} 3^{24}$

Locust-tree, 293

Lupin, I47

\section{Mangroves, 54}

Manitoba, 6r

Manuring, 6r, I45

Maple, rog, 294

Melon, I2, I 2, II3, ז85, 197, 282, 290, 348

Mesquite, IrI

Mice, 333

Mineral matter in plants, $17,6 x, x_{40}$

Mississippi, 44

Mistletoe, $272-3$

Mole, 66, 335

Mongoose, 323

Monkeys, 264

Moss, 32, 140

Moths, 23I-2

Mud, river, $42,46,53$

Mummy-wheat, 282

NAMES, CAution as To, 344

Nettle, 223, 247, 305, 348
Nile, 42-44, 134

Nitrates, I 5 1-6

Nitrogen, $148-52$

11 compounds of, $153,158,160$

$\mathrm{North}_{2}$ vegetation of, 188

Nubia, desert of, I2I, I87

Nuthatch, 264

OAF-FORESTS, 262

Ohio, crops in, 133

Oleander, 224, 347

Olives, 346

Orange, 220, 308, 35I

Orchids, 228, 23r, 283-5, 307

Organic matter in soil, 6r

" " required by plants, 148

Ovary, 195

" development of, $2 \mathrm{I}_{3}$

Ovules, I95, 199, 206, 212-13, 248

Owls, 333

Oxalis, 222

Oxygen, 19

PALMS, 193, 2 ro

Pampas, 3, 4, 64, 146

Pará, vegetation at, 8

Passion-flower, 204, 224, 307

Peru, rainless zone of, 5

Phoenicians, 347

Pigs as planters, 276, 292, 355

Pimento walks, 27I

Pines, 57, 95, 100, 209, 339

Pistil, 195, 212, 255

Pitcher-plants, I5I, 235

Plantain, 342

Poisonous plants, 302

Pollen grains, I97, 200

" poisonous, 204, 221

, tubes, 200, 205, $2 I_{3}$

il masses, 23I

Potato, 344, 355

Prickly pear, 35,36, II $, 353,35^{8}$

Primrose, 142, 194, 222, 228

Protection against enemies, 240, 243, 300

" $"$ evaporation, 95-100

RAFFLESIA ARNOLDI, 194

Ramfall, II5-23

Raspberry, fertilization of, 2 I9

Rats, 65, 29r seeds, 283

Redstart, 320

Red snow, 7, 185

Rhône, 45

Ripening of fruit, $179-8 \mathrm{r}, \mathbf{1 8 5}$

Riverina, 292 
Rivers, 43, 44, 46, 53

Rooks, 262, 330

Romans, 3489

Roots, 35. 52, 55, 58, 80, 124

, acid in, $35,13^{6}$

", hairs of, 13t

" length of, $\mathrm{r}_{3} \mathrm{I}$

$\therefore$ effect of sun on, 187

" worm-burrows and, 135

Rose, garden, 346

") -trees and snow-drifts, 57

Rushes, 55

Russia, 61, 62, I34, 144, 146

Rust, I9

Saffron, 35T

Sahara, I 19

Salt, I43

', -worts, 144

Salts, 137, 153

Sand-drifts, 51, 57

Santo Domingo, garden in, I3

Sap, 92, 107-9

Saracens, 349

Scarlet-runners, $\mathbf{I}_{3}$

Scents, 208, 223, 225, 237-9, 303

Sea-reed, 55

," -sedge, 55

„-water, 16, 140

" -weeds, $\mathbf{I}_{5}$

Serige, bristles of, 268

Seed, destruction of, 286-7

" carried by animals, $265,276,3.55$

" $\quad$ " birds, 260-72

" "fish, 275

" "locust 5,275

". water, 256.9

" " wind, 5I, 253

" eaten, 327

, feathered, 255

" hooked, 265

"in mud, 268

, nitrogen in, 160

", mystery of, 277

Secds, hard coats of, $272,283,293$

, quantity of, 287

II self-burying, 289

") similarity of, 279

". size of, $28 \mathrm{r}$

" vitality of, $28 \mathrm{r}$

Seedlings, destruction of, r2, 284, 300, 3I9

Seed-vessels, exploding, 252

Smell, sense of, 24I, 303-4

Snow drifts, 57

Soil, ro, 6I-4

". colour of, 185
Soil, moisture in, 126

,) warmth of, 185

Sparrows, 324-7, 33I

Species cultivated, number of, 4

Squirrels, gray, 264

, ground, 64

i. red, 263

, tree, 263

II seeds planted by, 264, 292

Stamens, 195

Starch, I66-7 and petals, 196

Steam, 24

Sugma, 199

Sitrawberry, 218

Suez Canal, r2o

Sugar-cane $35 \mathbf{I}$

Sundew, $x 5^{\circ}$

Sunflower, Io3, I51, 344

Sunlight, 161, I77

Swallow5, 317, $3^{23}$

TEMPERATURE, 177

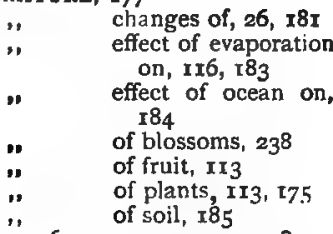

Thistles, 146, 297, 303, 331, 357-8

lesms, 305-6

Ticks, $3^{22}$

Titmouse, 32x

Tobacco plants, I26

Tokay, I43

Transpiration, 93, 106

Trees, destruction of, 56, I 5 , I 8

Tulip, $35^{\circ}$

1" effect of, on air and soil, 57 , $\mathrm{xO}_{3}, \mathrm{xI} 8-21,33^{8-9}, 355$

Turkeys and hedges, 272

Turkestan, birds in, 324

Turks, 350

VAILLISNERIA, 214

Vanilia 298

Venus's tly-trap, 149

Vine, I43, I80, I87

Vineyards, I43, I59

Violet, 205, 206

WARMTH OF BLOSSOMS, $23^{8}$

W" need of, 217

Wasps, 235-6, 335 
Water, 6, 16

" absorbed by soil, 125

". given up by plants, 102, 104, II6

\# in plants, go

". movement of, in plants, 108

i" in soil, 125, 128

Water-lily, $25^{6}$

") -pink, 256

Wax, 93,96
Weeds, 286, 341-3, 348, 356, $35^{6}$

Wind, birds carried by, 269

"dust carried by, $46,5 \mathrm{I}$

". fertilization by, 208-12

i. seeds carried by, 253

Wireworm, 329-30

Worms, 73-83, I35

Wren, $3^{21}$

YELLOW EARTh, 145 








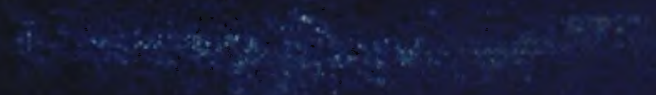

